Lero

à esquerda

Paulo Arantes 


\section{Zero à Esquerda}


A coleção é organizada em sete categorias e três subcoleções, com diferentes tipologias documentais e formatos de arquivos:

Categorias: Filosofia; Política; Estética; Arquitetura e Cidades; Artes Plásticas; Crítica da Cultura e Trajetórias. Cada categoria adota uma cor específica aplicada na capa do e-book.

\section{Subcoleções:}

E-books: livros, capítulos, prefácios, artigos e entrevistas (em formatos PDF, EPUB e MOBI/Kindle) - com obras em português, inglês, espanhol, italiano e francês.

Documentos: matérias de jornal, fotos e documentos históricos (em formatos

PDF e JPEG)

Mídia: vídeos ou áudios de palestras, aulas e debates (em formatos MP3 e MP4) associados a um canal da coleção no YouTube.

Coordenação editorial: Pedro Fiori Arantes

Projeto Gráfico: Paula Astiz

DADOS INTERNACIONAIS DE CATALOGAÇÃO NA PUBLICAÇÃO (CIP)

(CÂMARA BRASILEIRA DO LIVRO, SP, BRASIL)

Arantes, Paulo Eduardo, 1942-

Zero à esquerda [recurso eletrônico] / Paulo Eduardo Arantes. --

São Paulo : [s.n], 2021

ePUB. - (Coleção sentimento da dialética / coordenação Pedro

Fiori Arantes)

ISBN 978-65-00-33899-7

1. Brasil - Política e governo. 2. Direita e esquerda (Ciência

política). 3. Globalização. 4. Filosofia. I. Arantes, Pedro Fiori, 1974-.

II. Titulo. III. Serie.

CDD 306.2

Elaborado por Cristiane de Melo Shirayama - CRB 8/7610

DOI: https://doi.org/10.34024/9786500338997

\section{(1) $\Theta \Theta$}

Esta obra tem licença Creative Commons internacional 4.0

http://creativecommons.org/licenses/by-nc-nd/4.0/

Publicado originalmente como:

ARANTES, Paulo Eduardo. Zero à Esquerda. São Paulo: Conrad, 2004. ISBN 85-7616-

038-2

\section{Sentimento da Dialética}

UM ENCONTRO COM A OBRA DE OTÍLIA E PAULO ARANTES

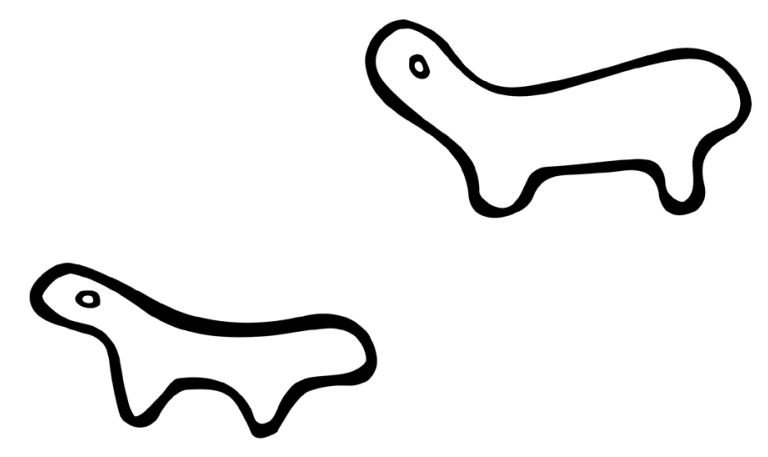




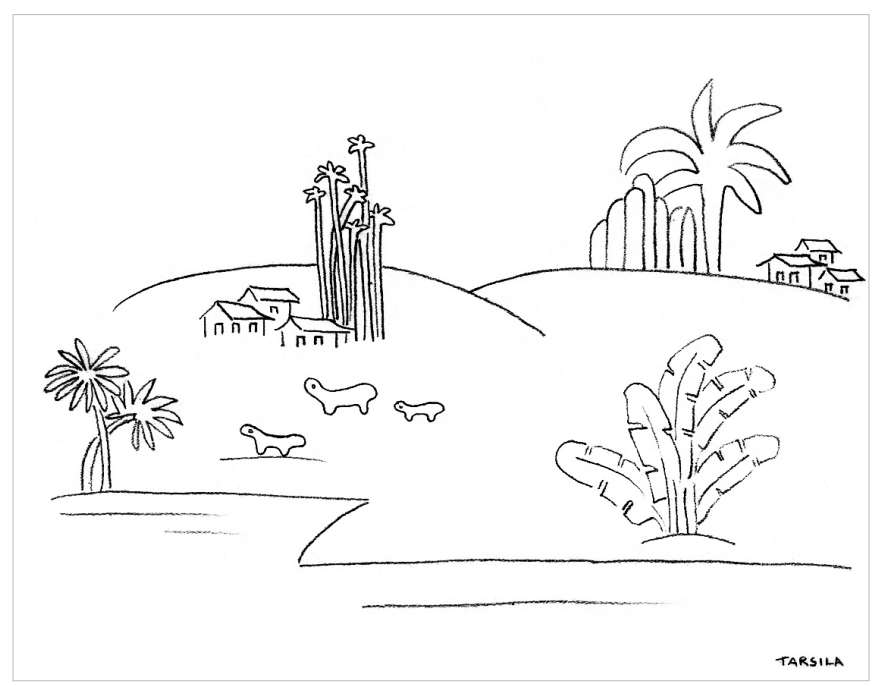

Tarsila do Amaral. Paisagem antropofágica - I, 1929 c - lápis s/ papel, 18,0 x 22,9 cm. Coleção Mário de Andrade. Coleção de Artes Visuais do Instituto de Estudos Brasileiros USP. Reprodução gentilmente cedida pela família e IEB USP.

O novo tempo do mundo exige dos intelectuais responsabilidades que lhes são intrínsecas: a de tornar a força das ideias parte do movimento de entendimento e transformação do mundo. Os filósofos Otília Beatriz Fiori Arantes e Paulo Eduardo Arantes cumprem, juntos, há mais de 50 anos, a tarefa da crítica como intelectuais públicos atuantes, transitando entre diversas áreas das humanidades e da cultura, em diferentes audiências e espaços de formação. A coleção Sentimento da Dialética é um lugar de encontro com a obra de Otília e Paulo Arantes e reafirma o sentido coletivo da sua produção intelectual, reunida e editada em livros digitais gratuitos. É um encontro da sua obra com um público cada vez mais amplo, plural e popular, formado por estudantes e novos intelectuais e ativistas brasileiros. É também um encontro da sua obra com o movimento contemporâneo em defesa do conhecimento livre e desmercantilizado, na produção do comum e de um outro mundo possível. 


\section{PARTE I}

13 Extinção

$31 \quad$ A fratura brasileira do mundo

113 Nação e reflexão

161 Eles sabem o que fazem

\section{PARTE II}

165 O "pensamento único" e o marxista distraído

191 Nem tudo que é sólido desmancha no ar

197 Utopia e revolução

211 Recordações da recepção brasileira de Herbert Marcuse

$219 \quad 1968$ trinta anos depois

223 Marx cult 


\section{PARTE III}

229 Esquerdae direita no espelho das ONGS

267 Sofística da assimilação

311 Documentos de cultura, documentos de barbárie

335 O nome do sujeito

\section{PARTE IV}

341 “Zero à esquerda”: uma coleção da hora

361 Conversa com um filósofo zero à esquerda

\section{EPÍLOGO}

427 Beijando a cruz 


\section{PARTE I}

\section{EXTINÇÃO}

A FRATURA BRASILEIRA DO MUNDO

NAÇÃO E REFLEXÃO

ELES SABEM $O$ QUE FAZEM

\section{Extinção}

\section{(Uma carta ao Painel do Leitor)*}

"Uma das lições que a Era Hitler nos ensinou", escreviam há mais de meio século Adorno e Horkheimer, "é a de como é estúpido ser inteligente". Pensavam nos bons europeus, modernos e civilizados, que durante uma década pavimentaram a ascensão do Terceiro Reich com argumentos de lógica impecável acerca da inviabilidade de tamanha aberração. Lembravam-se por exemplo de uma conversa com um brilhante economista que lhes demonstrara por $a+b$, com base nos interesses objetivos dos cervejeiros bávaros, que uma uniformização da Alemanha era impossível. "Depois os inteligentes disseram que o fascismo era impossível no Ocidente. Os inteligentes sempre facilitaram as coisas para os bárbaros, porque são de fato

* Publicado originalmente na Folha de São Paulo, Caderno Mais!, 27 de maio de 2001. Na edição impressa de Zero à esquerda da ed. Baderna, publicado com o título de "Apagão". Mantivemos aqui o título original [N.E.] 
estúpidos. São os juízos bem informados e perspicazes, os prognósticos baseados na estatística e na experiência, as declarações começando com as palavras: 'Afinal de contas, disso eu entendo', são os statements conclusivos e sólidos que são falsos". ${ }^{1}$

Pois bem. Noves fora os calafrios de praxe - sem falar na modesta envergadura dos pigmeus envolvidos, tanto os bem pensantes quanto os facinorosos -, estamos em casa. Falo é claro dos inteligentes de São Paulo e de suas ramificações nacionais e internacionais de alto nível. Digamos que a estupidez da inteligência foi se tornando nos últimos tempos uma original contradição paulista. Não ignoro que a transformação da inteligência em estupidez parece ser um traço tendencial da evolução histórica e que assim sendo não se poderia honestamente atribuir à índole singular de um agrupamento humano o que é puro efeito de relações sociais. Pelo sim pelo não, até por mero instinto de sobrevivência e na condição de criatura desta elite bem falante e escrevente, acharia prudente, nessa quadra turbulenta da nacionalidade, pelo menos um solene pedido formal de desculpa aos brasileiros e brasileiras que há sete anos aturam - entre tantas outras delicadezas de atenção social - o estribilho da referida pedantocleptocracia, entoado por impressionante massa coral: Afinal de contas, disso nós entendemos! E como!

Os hierarcas do império nazi eram bárbaros, e naturalmente inimigos mortais da vida do espírito. Mas há também um outro tipo de espírito que é anti-humano, insistiam nossos dois filósofos fracassomaníacos. Podemos reconhecê-lo pela sua marca de origem: a "superioridade

1. Adorno e Horkheimer, Dialética do Esclarecimento, trad. Guido Almeida, Rio de Janeiro: Jorge Zahar, 1985, p.195. bem informada". Não há por certo termo de comparação entre os grandes chefes fascistas de ontem e os comparsas tropicais de agora, de sorte que acabamos nos conformando com o tamanho bem paulista a que se reduziram antigos sonhos de suprema elegância, alta cultura e poder - este último, sans phrase. Assim, no lugar da tremenda camarilha teutônica, ocupa a cena o cortejo mambembe que se está vendo: o fotogênico Eduardo Jorge, o lombrosiano Jader, o schumpeteriano Mendonção e seu ídolo, o beato Serjão (que Deus o tenha no Paraíso que escolheu), o galante Ricardo Sérgio, o majestoso ACM, o brejeiro delfim de Hannover etc. etc. ${ }^{2}$

Mas, e onde se lê Espírito, ainda por cima em alemão? Aqui sim a transposição local nos favorece plenamente. Os senhores hão de convir que pelo menos em matéria de superioridade bem informada, a Escola Paulista de Pensamento - na qual me formei e não posso renegar - praticamente não tem rival. Pois então é isso, vistas as coisas aqui da capital do FHnistão. ${ }^{3}$ Ingratidão maior nunca se viu: como pode o Brasil totalmente esclarecido pelos intelligenti de nossa Escola ousar resplandecer sob o signo de uma calamidade triunfal? Além do mais, às vésperas de um Apagão. Só pode ser obscurantismo. Afinal de contas,

2. Não ignoro que esta enumeração aleatória está confundindo duas ordens de fenômenos, as quais o renomado Dicionário do Almanaque Filosófico, da Editora Vozes, na sua edição de 1997, manda distinguir, a saber, a corrupção de tipo B, inferior, corrupção atrasada e ainda tributária do paradigma desenvolvimentista; e a superior, de tipo A, A de Agência, dita de acumulação flexível (p. 26). Antevendo a atual apoteose, já naquela edição do referido Almanaque (ainda disponível à rua Frei Luís, n.100, em Petrópolis) anunciava-se o fim próximo da Era Vargas, no entender do dicionarista, um modo de produção asiático, em vigor durante meio século no Brasil, destinado entretanto a um fatal desaparecimento desde o momento em que o atual regime retomara o processo de ocidentalização do país, interrompido em 1930 (cf. Ibidem, p. 35).

3. Copyright José Simão. 
disso vocês não entendem nada! Prova disso, o eminente colapso energético do país, o qual precisa entender de uma vez por todas que acabou a fase de energia farta e barata no Brasil, que vivemos um processo de pós-industrialização, pelo qual já passaram economias mais modernas, conforme anunciou o diretor-geral da Agência Nacional de Petróleo, sem que ninguém tivesse chamado a polícia ${ }^{4}$

Alguma coisa no entanto estamos começando a entender. Estamos enfim reaprendendo com a Era Fernandina como de fato ficou brutalmente estúpido ser inteligente. Com uma diferença notável - como tudo nessa terra de varões sabedores - e que vem a ser propriamente a contribuição original brasileira para o processo mundial de corrosão da inteligência. Na estupidez terminal do espírito superior com que se depararam a seu tempo Adorno e Horkheimer, quando redigiam com resignação filosófica a declaração de falência da civilização europeia, explodia em todo seu esplendor a contradição inaugural da razão que comandara aquele processo em colapso, a inteligência liberal, a um tempo universal e particularista, numa palavra, "o instrumento do privilégio na igualdade". Na hora do Apocalipse, era a ela que o fascismo estava apresentando a conta. Um ciclo histórico depois e a correspondente derrocada da Era do Crescimento, o pensamento que ora se extingue é de uma outra espécie. Digamos, para encurtar, da espécie que nos habituamos durante dois séculos a chamar de "progressista", ou, para ser mais específico, o lado oposto, o lado propriamente esquerdo daquela ma-

4. FSP, 10.05.01, B3. Na ocasião, o mesmo cunhado do príncipe de Hannover deu como exemplo o Japão dos anos 70 que, devido ao alto custo de energia, transferiu para o Brasil sua produção de alumínio. Porém nada mais disse nem lhe foi perguntado. triz original de evolução e reforma do mundo. Aqui entramos nós, o breve porém substancioso capítulo paulista do atual processo de autodestruição da inteligência brasileira, que vai assim arrematando o seu "ajuste" ao padrão global da estupidez bem pensante. E por mais que a analogia nos repugne, é bom não esquecer a lição do apocalipse nazi, desta vez por uma autora insuspeita de fracassomania, Hannah Arendt: a descoberta da mais aterradora crueldade social germinando no processo aparentemente banal de corrupção da inteligência ${ }^{5}$. É claro que a analogia é estritamente filosófica, apenas uma meditação acerca de um caso catastrófico de inibição da reflexão. De qualquer modo, embora a escala mundial do desastre em curso atualmente seja de meter medo, por aqui a dosagem ainda é homeopática, pelo menos do ângulo de um homem branco de classe média, constatação cujo simples enunciado já é uma ameaça. Voltando aos efeitos letais da inteligência paulista no poder, o fato intrigante é que deve ter saído de cena algo essencial que nos fazia pensar - se não for presumir demais.

Seja como for, o fato é que toda uma tradição outrora crítica, não só foi sugada pelo moinho satânico da estupidez inteligente como passou a acionar-lhe a manivela, com o deslumbramento característico da supracitada superioridade bem informada. Numa palavra, o que a Era Cardosista do Esclarecimento está mostrando neste momento de glória da malandragem nacional é como se tornou apenas bête et méchant procurar ser inteligenterrimamente de esquerda, e isso, depois de decretado pelos mesmos altos personagens o Colapso da Modernização,

5. Cf. Hannah Arendt, Eichmann em Jerusalém, São Paulo: Cia. das Letras, 1999. 
sem a qual, justamente, fica muito difícil distinguir uma explosão criativa de forças produtivas de meros serviços de corretagem. Cochilo grave para um crime ideológico quase perfeito, esse da lavagem de conceitos. Mas são derrapagens sem sujeito, diria algum espectro althusseriano, relançando a espiral do autoengano. Por exemplo, diante da piranhagem que foi o episódio Telebrás, algum incorruptível veterano do leninismo poderia muito bem replicar que mais vale um salto econômico arrancado a fórceps do que a grita moralista das camadas sociais sem futuro, etc. Homens de ferro para os quais sou o primeiro a tirar o chapéu. (Muitos deles, com o peito coberto de medalhas, estão no governo. Continuo tirando o chapéu, desde que não me penhorem as antigas medalhas.) Nem por isso menos empulhados pela inércia de um raciocínio cujo nervo histórico se extinguiu, mas sobretudo mesmerizados pelo teatro de sombras dos operadores da nova classe que, justamente afiançados pela nobre estirpe da finada teoria crítica, vão tocando o violento trivial do big business como quem toma o Palácio de Inverno, agora sim, literalmente de assalto, acossados, é claro, pela guerrilha impatriótica dos atrasados. Assim se constituem os fundos secretos para uma eterna segunda rodada bolchevique, algo como foquismo na Sociedade Hípica.

Aqui a matriz operacional de outra formidável invenção ideológica da Era Fernandina, a chamada "rebeldia a favor". É assim que a mais crassa estupidez dos inteligentes vai fazendo a cama dos novos bárbaros, parceiros estratégicos que ingratamente caluniam em momentos de troca da guarda como agora. Nessas horas, o sangue-frio materialista da velha guarda costumava recomendar que se aprendesse com quem se vende, no que tinham toda razão. A nova hegemonia sempre anunciava a sua che- gada arrematando cabeças, no geral inconformadas com o estado das artes. Pelas razões erradas, quem se vendia estava à frente dos obtusos e incorruptíveis. Estudando o caso, como numa cena brechtiana, os amigos de esquerda do progresso aprenderiam a encarar as coisas novas e ruins a partir das quais se deveria recomeçar. Estamos vendo nestes tempos cardosistas que já não é mais o caso. Não deve ser apenas por algum defeito de fabricação do personagem - o imortal inventor da rebeldia a favor - que não aprendemos nada com as suas genuflexões, embora não se possa negar a audácia de seu enorme passo adiante. Simplesmente não há mais chão para tal passo, quem nos compra não está mais desbravando nenhuma fronteira da valorização. Portanto já não faz mais diferença alguma distinguir, como exigia um clássico do materialismo paulista: vendeu-se, está criticando, ou vendeu-se criticando.

No seu devido tempo, veremos porque a transformação histórica da inteligência em estupidez - este o ponto, já que estaremos interessados em pesquisar a gênese paulista da bêtise na origem da atual derrocada da inteligência brasileira - diz respeito primordialmente ao toma-lá-da-cá das operações elementares de compra e venda. Mas não será preciso remontar à pré-história. Pode-se reconhecer a mesma lógica ancestral - girando como os ponteiros de um relógio no pulso de um morto - observando a espécie de reflexo condicionado daqueles que têm resposta para tudo. Amostragem relâmpago: 1) Política de terra arrasada com os petroleiros em greve? É claro, precisam aprender que estamos trocando capitalismo velho por capitalismo novo; 2) Previdência social? Totalmente inviável, como um simples cálculo atuarial pode demonstrar, fulano traga os números; 3) Sim, nomeou um antigo torturador chefe da polícia federal: certamente precisou 
negociar coisa mais graúda. E por aí afora.

E para trás também, caso recuemos até os primeiros sintomas dessa bancarrota do modo paulista de pensar. Vejamos por exemplo o que dizia um filósofo e colunável, enquanto transcorria em Brasília a CPI que desembocaria no impeachment do Antecessor: "Ninguém é movido por interesses universais e não se pode pedir aos políticos que abdiquem do esforço pessoal de buscar o poder (...) Em vez do discurso moralista, cabe aceitar que os políticos agem por interesse privado, mas como só podem fazer em nome do bem comum, que ele calcule seus riscos de ser pilhado em público toda vez que atuar exclusivamente em nome de seu bem particular (...) Desse modo constitui-se uma moralidade pública que comporta a infração nos seus interstícios."6 $\mathrm{E}$ ainda dizem que a coruja do filósofo só alça voo ao fim do dia, pois este mocho paulista madrugou com uma década de antecedência! O estudo da amostra requer entretanto o escrutínio objetivo do naturalista. Trata-se afinal de um processo sem sujeito, a rigor mecânico, como sugere o curioso símile que arremata o raciocínio: "Mesmo quando os indivíduos agem em nome do bem comum, a luta pela obtenção e manutenção do poder implica o exercício dum empuxe individual"7. A fome de imanên-

6. J.A. Giannotti, FSP, 07.06.92. Ao leitor interessado em apreender o conceito de "infração intersticial", recomendo a consulta ao mencionado Dicionário publicado pelos bons frades de Petrópolis, onde encontrará à p. 27 a seguinte definição: "Manobra radical pilhada em flagrante desvio semântico. Equívoco categorial afiançável”. Na última edição do referido Almanaque, encontrará o leitor interessante aplicação atualizada do conceito: "Exemplo de infração intersticial: na recente violação do painel do Senado - 'estelário cívico', conforme a última produção poética do bacharel de Cananéia, Senatus Populusque Brasiliensis, todavia um caso paulista atípico de extinção de nascença - dir-se-á que a infração, sendo intersticial, não fere a regra do decoro parlamentar, uma vez que se deu seguindo uma outra regra, cuja gramática deve ser procurada numa outra lógica, a da intimidade, para ser exato".

7. Como se trata de complexo termo técnico de Mecânica Celeste, poderá o lei- cia que parece caracterizar este singelo cálculo de custo/ benefício parece fornecer uma excelente ilustração para aquilo que o iberista carioca Luís Werneck Vianna vem chamando de "física paulista dos interesses", por oposição à irrazoável tendência metafísica do povo brasileiro a achar que é possível vida para além do mercado. ${ }^{8}$ Além de ilustrar é claro, no andar superior da cadeia alimentar dos bens informados que têm resposta para tudo, o vínculo arcaico entre a inteligência e as raciocinações do Poder acerca das vantagens que consegue obter quando se resigna a seguir as regras do jogo. Na opinião descalibrada de Adorno e Horkheimer, que por certo andaram gazeteando os cursos de Lógica.

Recordo a propósito, para voltar mais uma vez aos dois catastrofistas de Frankfurt, que talvez o sinal de alarme deles tenha começado a soar quando perceberam o que Chamberlain entendia por "ser razoável” ao reclamar das exigências de Hitler, a seu ver unreasonables. Numa palavra, parece que o Führer não respeitava muito a equivalência entre dar e tomar. Se oferecesse um preço justo para os territórios e populações que estava prestes a abocanhar, tudo bem. Essa a rota suicida da estupidez dos inteligentes e elegantes, cujo espírito se apaga "tão logo o Poder deixa de obedecer à regra do jogo e passa à apropriação imediata”. De um ponto de vista histórico-mundial, como se dizia na esquerda hegeliana, tanto

tor recorrer novamente ao providencial Dicionário, ao que parece compilado na intenção dos prováveis sobreviventes do apagão da inteligência nacional. "Empuxe individual - golpe de manivela que coloca o Ego em movimento. Acionar o mecanismo com precaução: perigo de fissura e escapamento (v. fissura e escapamento)". Pp. 37-38.

8. Cf. Luís Werneck Vianna, A revolução passiva: iberismo e americanismo, Rio de Janeiro: Revan, 1997. 
faz se se trata de um Gauleiter, um bicho solto de boca de fumo ou, enfim, um "investidor" atuando no ramo das privatizações. Assim sendo, se a fórmula "vendeu-se" choca e ofende, não seja por isso, troca-se por uma outra equivalente, “ajustou-se”. Por exemplo: ajustou-se gemendo (virou estadista), ou ajustou-se, está gemendo (virou existencialista). Digamos então que a derrocada se consumou quando uma certa tradição crítica bem paulista se adaptou. Mas aí nossos incorrigíveis fracassomaníacos alemães completariam o raciocínio, lembrando que na história natural da inteligência, sua extinção na estupidez vem a ser justamente "o dernier cri da adaptação". E nada mais feroz que a predação dos adaptados (ainda mais quando procuram apenas sobreviver). ${ }^{9} \mathrm{~A}$ violência pré-histórica da "globalização" em curso nada mais é do que a expressão, banalizada pelos notáveis do espírito, de mais uma rodada dessas "adaptações" próprias da derradeira civilização baseada na crueldade bem calculada do trabalho excedente. ${ }^{10}$

Em tempo. Certamente o processo de extinção que está nos interessando identificar não é nem poderia ser unilateral. Ele também se espraiou pelo campo oposto, o mundo do trabalho, onde havia igualmente vida inteligente. A fundação absolutamente inédita de um recurso emancipatório inestimável como uma Partido de Trabalhadores que o diga. Juntamente com o Solidarnosc po-

9. P.: "Qual a prioridade do presidente para o fim do governo?" R.: "Bom, do jeito que está, será sobreviver”. Entrevista de J.A. Giannotii a Luís Henrique Amaral: "Moral e política não se misturam", O Globo, 13.05.01.

10. Na extraordinária formulação de Marx, reativada recentemente por Fernando Haddad, in Sindicalismo, cooperativismo e socialismo, São Paulo: ed. da Fundação Perseu Abramo (no prelo). lonês, a única iniciativa antissistêmicas em ascensão durante a década de 80, quando o Império deflagrava sua Contrarrevolução mundial. O movimento polonês, como se há de recordar, foi o primeiro a sumir no ralo da nulidade social, e o nosso já vai apresentando sintomas alarmantes de decomposição dourada.

Com toda razão o mesmo Luís Werneck Vianna costuma incluir na física paulista dos interesses o movimento browniano das grandes centrais sindicais aqui do pedaço - e, podemos agora acrescentar, o tipo de inteligência esperta das trocas simbólicas e materiais que lhe constitui a razão dominante. Enfim, quem não se lembrará, entre tantos outros, do lance mais do que meramente retórico de um líder sindical excluindo de uma "reforma" da Previdência, ainda por combinar com os de cima, os que nela nunca estiveram incluídos, e por isso mesmo. Faz sentido. Trata-se de uma simétrica opinião-espelho da convicção sociológica da alta tucanagem, segundo a qual o povo miúdo que descola uma aposentadoria na boca do caixa sem nunca ter integralmente contribuído durante as décadas em que se virou da mão para a boca é o primeiro fraudador da Previdência. Dialética da malandragem oblige? Como diria um grande lógico paulista, diante de um grafite no banheiro - "todo lógico é idiota/o Professor X é lógico/ logo, o Professor X é idiota" - pelo menos formalmente está correto. Seja dito em homenagem à neutralidade epistemológica que sempre distinguiu a Escola Paulista de Pensamento, o Professor X era ele mesmo. Conosco é assim mesmo, os conceitos, quando são bons, como os nossos, são muito democráticos, não fazem distinção de classe.

Continuando. Numa tese recente, mostrou-se como a contribuição dos assalariados para os antigos IAPs da famigerada Era Vargas financiąram as estatais originárias, 
torradas agora para fazer o caixa do populismo cambial do primeiro mandato." Entre elas, a Vale do Rio Doce, arrematada a preço de banana nas condições que se sabe, como compete a um Estado-corretor de big business. ${ }^{12}$ Pois não é que também ouvi outro dia um líder sindical, com imponente folha de serviços prestados durante o auge do sindicalismo de combate do período anterior, saudar o "companheiro Benjamin" (Steinbruch mesmo) como "parceiro de primeira hora" num louvável empreendimento de charity business? Outro louvável "parceiro de primeira hora" (idem, ibidem) o companheiro BankBoston.

Num ensaio recente, Francisco de Oliveira dá uma boa pista para se rastrear, no chão material dessa outra metade da física paulista dos interesses, o correspondente processo de extinção mental, neste caso, por motivo de extenuação na base social da espoliação. ${ }^{13}$ Com efeito, contrariando o besteirol corrente sobre a perda da centralidade do trabalho, Chico de Oliveira não só também constata uma espantosa extensão do assalariamento - no sentido

11. Eli Gurgel Andrade, (Des)Equilíbrio da Previdência Social Brasileira, 1945-1997, UFMG, 1999.

12. Para um bom enquadramento da atual parolagem acerca da transição modernérrima do Estado-produtor (Brasil I) para o Estado-regulador (Brasil II), ver José Carlos Miranda e Maria da Conceição Tavares "Brasil: estratégias da conglomeração”, in J.L. Fiori (org.) Estados e Moedas no desenvolvimento das Nações, Petrópolis: Vozes, 1999. Exemplo: "A Agência Nacional de Petróleo está obrigando a Petrobrás a ceder o uso do gasoduto Brasil-Bolívia [cuja construção ela mesma bancou], à British Gas, arbitrando uma tarifa muito inferior à que a própria estatal vai pagar. Essa benesse da ANP dará à BG condições de vender mais barato o gás à custa da empresa brasileira. Isso se chama livre-mercado ou facilitação do poder público?" (Fernando Siqueira, presidente da Associação dos Engenheiros da Petrobrás. FSP, Painel do leitor, 11.05.2001, p.A3.) O rapaz não sabe lógica, não entendeu a Gramática do Capital.

13. Cf. Francisco de Oliveira, Classes sociais em mudança e a luta pelo socialismo, São Paulo: ed. da Fundação Perseu Abramo, 2000, pp.14-21. amplo do termo - sem paralelo mesmo considerando-se os anos dourados do fordismo, ampliação que se estende da mais cruenta extração de mais valia-absoluta até o trabalho não pago do cliente de serviços que também labuta ao consumir, mas um igual aprofundamento da privatização do trabalho, entendo-se com isso a privação de sua dimensão pública, tanto por motivo de precarização e informalização galopantes, como de predação do tempo privado de "não-trabalho" pelo emprego on line da massa crescente de trabalhadores à disposição. A seu ver, esses dois movimentos tornam o velho conceito marxista de exército industrial mais atual do que nunca, desde que devidamente reinterpretado, na medida em que "praticamente todos os trabalhadores converteram-se em seus membros intermitentes/latentes pela permanente desqualificação e informalização". Assim sendo, a fração propriamente ativa tornou-se minoritária, enquanto a fração estagnada ou lumpen tende a crescer. Mais importante, o fundo público que se origina da relação contratual de compra e venda de força de trabalho, e quando se constitui, perde seu antigo poder de veto sobre o capital. Com isso, continua Chico, a mera "gestão" dos fundos públicos, tais como FAT, PIS, PASEP, FGTS, e não a sua “apropriação pública”, torna-se objetivo maior dessa fração ativa do exército industrial. Nessas condições, os membros desse núcleo preservado (e olhe lá!), convertidos em sujeitos monetários privatizados não podem nem querem saber da massa sobrante do seu exército. Deve passar por aqui a base material dos dois lances de idiotia social referidos acima. Sobre tal base se ergue a mesma derrocada da inteligência no mundo do trabalho.

É claro que Chico de Oliveira empregou deliberadamente a expressão de Robert Kurz "sujeitos mo- 
netários", fórmula que nesse meio tempo acabou ganhando novo conteúdo, à medida que seu autor foi reabrindo o dossiê do mundo do trabalho que precipitadamente julgara abolido. Pois, comentando o argumento bem conhecido de Richard Sennett sobre a corrosão do caráter dos indivíduos flexibilizados pela desqualificação do trabalho sob o novo capitalismo, Kurz também realça o impulso autodestrutivo que consome tais mônadas "universalmente exploradas e solitárias", um novo universo da espoliação em que os empregados vão se tornando "manhosos e sem coesão social, que só sabem lograr seus superiores, os clientes e seus demais colegas"14.

Aqui o outro foco do ponto cego em questão. A anulação mental induzida pela privatização do trabalho atroz - como alguns autores franceses chamam a coisa - vem a ser o reverso de uma tolerância crescente com o intolerável - no caso, a injustiça abismal na sociedade polarizada de hoje. Algo como uma reação defensiva igualmente cruel ante o sofrimento que se é obrigado a infligir a si mesmo e aos outros, os que se veem passar nas levas sucessivas de precarizados e enxotados, pelo Sistema, é claro, como nos falsos juízos de atribuição que acompanham este encasulamento no medo. ${ }^{15}$ É neste momento que se dá a esterilização da faculdade de pensar e prospera o cálculo dos experts em sobrevivência, deserto mental onde cresce apenas a crueldade social que caracteriza todo eclipse da reflexão. Aqui voltamos ao topo dos esclarecidos. Ao niilismo da "viração" dos que embaixo moem no aspro, corresponde o "saco de maldades" ou o "Wall Street quer

14. Robert Kurz, “Descartável e degradável”, FSP, 11.07.99.

15. Cf. Cristophe Dejours, La souffrance en France, Paris : Seuil, 1998. sangue" de dois imortais mentecaptos da pedantocleptocracia fernandina.

Com uma diferença, seja dito por assim dizer em favor das vítimas. Como o nome indica, bêtise algo terá a ver com o reino animal. Refletindo sobre sua gênese, nossos dois fracassomaníacos frankfurtianos lembraram que o símbolo da inteligência é a antena do caracol. "Diante de um obstáculo, a antena é imediatamente retirada para o abrigo protetor do corpo, ela se identifica com o todo e só muito hesitantemente ousará sair de novo como um órgão independente (...) Em seus começos, a vida intelectual é infinitamente delicada (...) O corpo é paralisado pelo ferimento físico, o espírito pelo medo. Na origem as duas coisas são inseparáveis (...) Este primeiro olhar tateante é sempre fácil de dobrar, ele tem por trás de si a boa vontade, a frágil esperança, mas nenhuma energia constante. Tendo sido definitivamente afugentado da direção que queria tomar, o animal torna-se tímido e burro. A estupidez é uma cicatriz (...) Essas cicatrizes constituem deformações. Elas podem tornar as pessoas estúpidas - no sentido de uma manifestação de deficiência, da cegueira e da impotência, quando ficam apenas estagnadas; no sentido da maldade, da teimosia e do fanatismo, quando desenvolvem um câncer em seu interior. A violência sofrida transforma a boa vontade em má." ${ }^{16}$ São esses os pontos cegos que no interior de um indivíduo justamente, como estamos vendo, "designam as etapas em que a esperança se imobilizou". Porém, o que se aplica aos condenados da terra - ao mesmo tempo em que reconhece a massa bestificada pela hipnose fascista na história das frustrações da espécie -, não pode

16. Idem, ibidem, pp.239-240. 
evidentemente valer para a indigência histórica do reino animal do espírito que se instalou na capital cultural do FHnistão. Para tal reino não haverá filosofia que encontre circunstâncias atenuantes.

Como o Ser em Aristóteles, corrupção também se diz em muitos sentidos, inclusive na acepção brasileira do termo, como a seu tempo veremos, caso este folhetim continue. Ao falar em corrupção da inteligência brasileira, não me passa pela cabeça sugerir que até os maiorais de nosso falido espírito crítico estão criando rã no quintal. Primeiro porque acho que ainda não estou maluco a este ponto, segundo, e principalmente, porque sendo moralista, pelo menos com estas coisas não costumo brincar. Como não tive berço dialético - minha mãe estudou no Des Oiseaux e meu pai era udenista - peço que me relevem a estreiteza de espírito. Falha de formação sem dúvida. Mesmo tendo sido aluno aplicado da Escola Paulista de Pensamento, ainda não consigo encarar a corrupção com suficiente isenção sociológica. Azar, estou agora morrendo na praia. Vejam só, deixei escapar na undécima hora a Astúcia da Razão em pessoa, a manobra radical do genial estadista, na formulação não menos inspirada do filósofo Ortega y Nassif: "utilizar as armas da fisiologia para derrotar a fisiologia!" Aplicando este teorema do materialismo histórico em reconstrução, o fotogênico E.J. definiu-se com toda razão um lobista ao contrário. ${ }^{17}$

17. Para outras contribuições do pensador de Poços de Salamanca, ver ainda o citado Dicionário da Ed. Vozes, em especial à p.35: “O estadista é um intuitivo genial, que define um modelo de país na cabeça e centra todas as suas energias para concretizar o objetivo. Ele trapaceia, mente, engana, alia-se ao diabo." "Escrúpulo é coisa de intelectual", arremata o diretor-presidente da Agência Dinheiro Vivo, noutro lance premonitório acerca do destino da vida inteligente no país. "Obviamente, não basta a falta de escrúpulos", continua. O primeiro Fernando que o diga. No entanto, não sei se querendo demonstrar que tampouco é necessário muita sociologia, Ortega y Nassif, segundo registro do
Mas também não é dessa corrupção literal - na verdade uma metáfora fóssil - que estou falando, embora não ignore que a dita cuja é antes de tudo um sistema - sem sujeito é claro, porém com cadastro na Receita Federal. A corrupção que me interessa - a extinção da inteligência pela estupidez "crítica" - é muito mais assustadora (afinal tenho interesses profissionais no assunto), pois concerne a decomposição de uma tradição que se vai desmoralizando conforme apodrece. (Avisei que sou moralista.) Sendo assim, o estrago não é nada trivial, de fato uma hecatombe que no limite independe de eventuais traficâncias nas altas paragens do pensamento e do poder. Ou melhor, por isso mesmo interessa investigar - conceitualmente é claro... - o lugar do broker intelectual na hora pesada em que se encontram o dono do dinheiro e o dono do poder. Ali onde circulam, nas palavras famosas de Braudel, os grandes predadores e vigora a lei da selva, deve a inteligência se corromper na forma gloriosa da mais estupenda e cruel burrice.

Dada a calculada irreversibilidade das políticas de ajuste permanente como fim em si mesmo e o correspondente dano social irreparável que produzem, tudo indica que teremos cada vez mais do mesmo. Diante de uma tal escalada autodestrutiva, a constatação de que a tradição crítica brasileira não tem mais futuro, é uma catástrofe

mesmo Dicionário (p. 36), relembra que Fernando, o Breve, também mudou o país: "Collor teve a visão genial de entender que não implodiria este edifício getulista pedindo licença (...) Collor intuiu com uma clareza admirável o papel que caberia a cada agente político e econômico no novo país que estava sendo moldado. Essa visão genial foi sua grande virtude (...) O manual encontrado no PC de PC Farias demonstra a visão extraordinária dos novos tempos". Pela recorrência do fenômeno, é bem possível que no próximo reinado estejam operando uma terceira liquidação da Era Vargas e assim sucessivamente, como na finada União Soviética, a famosa herança asiática, quer dizer, ibérica, que nunca terminava de acabar, et pour cause. 
menor. Não sei se estou me fazendo entender, afinal não sou nenhuma exceção e a minha própria capacidade de pensar já deve ter se apagado faz tempo. Os paulistas no poder não são quaisquer, tampouco a desgraça mental que patrocinam. À sua própria revelia, bem entendido, conforme aprofundavam o ponto final em que chafurdamos, iam avançando, com fins apologéticos os mais rasos, nos fundos críticos acumulados pela referida tradição e, por esse caminho de autodestruição do saber herdado, convertendo ponto por ponto o que antes esclarecia e prometia libertação, no seu exato oposto conformista, como se quisessem demonstrar numa derradeira pirueta, cínica ou asnática, vá lá saber, que de fato cedo ou tarde toda Aufklärung, central ou periférica, acaba se convertendo no seu contrário. A nova mitologia dos fatos se expressa então no autodeslumbramento com que a feroz burrice dos inteligentes se congratula consigo mesma. Porém, o espírito crítico saqueado e barateado parece se vingar quando a antiga teoria crítica passa a funcionar como uma chinfrinzinha teoria tradicional de coisa nenhuma e ainda por cima mobilizada com a pompa e circunstância dos grandes acacianos para os fins da mais trivial dominação de classe.

\section{A fratura brasileira do mundo*}

\section{Encontro marcado}

Um dos mitos fundadores de uma nacionalidade periférica como o Brasil é o do encontro marcado com o futuro. Tudo se passa como se desde sempre a história corresse a nosso favor. Um país por assim dizer condenado a dar certo. Estudando certa vez as manifestações literárias deste velho sentimento brasileiro do mundo, Antonio Candido falou em consciência amena do atraso, correspondente à ideologia de país novo, na qual se destaca a pujança virtual, a grandeza ainda por realizar. ${ }^{1}$ Estado de espírito euforizante de tal modo arraigado a ponto de sobreviver até mesmo à revelação dramática do subdesenvolvimento, tal a confiança numa explosão de progresso que adviria, por exemplo, da simples remoção do imperialismo. E mais, o futuro não só viria fatalmente ao nosso encontro, mas com passos de gigante, queimando etapas, pois, entre nós, até o atraso seria uma vantagem. Fantasia encobridora reforçada inclusive pelo viajante estrangeiro ofuscado pela exuberância nacional, como foi o caso de um Stefan

Zweig, autor do mais celebrado clichê dessa mitologia * Publicado originalmente em José Luis Fiori e Carlos Medeiros (orgs.), Polarização mundial e crescimento, Petrópolis: ed. Vozes, col. Zero à Esquerda, 2001.

1. "Literatura e Subdesenvolvimento", in A educação pela noite, São Paulo, Ática, 1987. 
compensatória: Brasil, País do Futuro. ${ }^{2}$

\section{Procissão de milagres}

Ocorre que não faltou apoio na experiência nacional para a cristalização dessa miragem consoladora. A tal ponto, que Sérgio Buarque de Holanda se referiu certa vez à nossa história econômica como uma verdadeira "procissão de milagres". ${ }^{3}$ Primeiro, o milagre do ouro no século XVIII, a tempo de nos salvar na hora crítica em que a economia açucareira arrefecia seu ímpeto; depois, o milagre do café, caindo do céu quando o esgotamento das minas anunciava uma desagregação econômica ameaçadora. Pois bem: depois de ressuscitar esta visão irônica de uma atividade econômica por assim dizer veleitária, movida a arranques mais ou menos fabulosos, João Manoel e Fernando Novais acabam concluindo que, tudo bem pesado, "nossa industrialização não deixou de ser também um desses milagres: resultou antes de circunstâncias favoráveis, para as quais pouco concorremos, do que da ação deliberada de uma vontade coletiva”. ${ }^{4}$

2. Segundo um comentário recente, podemos imaginar o funcionamento dessa narrativa do surgimento de uma nação como "uma espécie de rodovia, um trajeto que leva das origens indígenas e coloniais, diretamente a um futuro glorioso: assentada sobre pilares de concreto, não se deixando desviar pela paisagem circundante e nem pelas eventuais saídas - e, sobretudo, sem possibilidade de retorno." Alexander Honold, "País do futuro ou Paraíso perdido?", in Praga n.9, São Paulo, 2000, p. 159. Por certo, imagem de um brasilianista que sabe do rodoviarismo desenvolvimentista e sua culminação em Brasília.

3. Passagem de Visão do Paraíso recentemente relembrada por João Manoel Cardoso de Mello e Fernando Novais em "Capitalismo tardio e sociabilidade moderna”, in Lilia Moritz Schwarcz, História da Vida Privada no Brasil, São Paulo, Cia. das Letras, 1998, vol.4, p.644-645.

4. Para a periodização dessa milagrosa industrialização tardia, que se beneficiou da relativa estabilização dos padrões tecnológicos e de produção nos países centrais ao longo do século XX, contando além do mais com as facilidades

\section{Sintaxe da frustração ${ }^{5}$}

Está claro que tamanha confiança nesse providencial encontro marcado com o futuro cedo ou tarde se tornaria uma fonte de frustrações recorrentes. De fato, toda essa fantasia progressista mal encobria o estado de ansiedade permanente em que vivia pelo menos a inteligência nacional - para não falar no bovarismo das camadas dirigentes propriamente políticas e econômicas. É só lembrar no século passado a aflição do abolicionista Joaquim Nabuco com a procrastinação das elites, cuja letargia escravista arriscava nos deixar de fora dos benefícios da Segunda Revolução Industrial. Não por acaso, poucos meses depois do fracasso de mais um plano de estabilização (o Plano Cruzado, lançado em fevereiro de 1986), numa entrevista igualmente marcada pelo temor de faltar ao nosso encontro marcado com a história, o mesmo João Manoel que linhas acima se dera conta do caráter milagroso da industrialização brasileira, recordava muito a propósito a advertência de Nabuco: "se mantivermos a escravidão, a gente vai ficar fora do que vai acontecer no mundo; a escravidão demorou muito para ser abolida e o Brasil ficou fora, não pegou

da cópia, cf. op.cit., p. 645-646. Sem falar é claro na excepcionalidade igualmente miraculosa da expansão capitalista durante os "trinta anos gloriosos" do pós-guerra.

5. A expressão é de Anatol Rosenfeld e se refere à estrutura "sem desenvolvimento" das narrativas de Kafka, em que os episódios se sucedem como nos romances picarescos ou nas histórias em quadrinhos, estrutura básica que se apresenta até mesmo na sintaxe das orações que "se iniciam com afirmações esperançosas que, em seguida são postas em dúvida, desdobradas nas suas possibilidades, cada qual ramificando-se em novas possibilidades. Pouco a pouco a afirmação inicial é limitada por uma inundação de subjuntivos e condicionais.” Texto/Contexto, São Paulo, Perspectiva 1969, p.232. 
este bonde." ${ }^{6}$ Mal começados os anos 90, ainda o mesmo autor e o mesmo compasso da frustração, na falta de uma nova procissão de milagres, cujas idas e vindas em todo o caso se parecem mais com a intermitência das miragens: "levamos cem anos, de 1830 a 1930, para imitar a inovação fundamental da Primeira Revolução Industrial, o setor têxtil. E noventa anos, de 1890 a 1980, para copiar os avanços da Segunda Revolução Industrial. Quando tudo dava a impressão de estarmos prestes a entrar no Primeiro Mundo, eclodiu a Terceira Revolução Industrial (...) Há dez anos, caímos na estagnação. Vivemos, hoje, à beira da depressão e da hiperinflação. E constatamos, a toda hora, com espanto e vergonha, a enorme distância que nos separa da civilização."7 Em tempo: o andamento melancólico do trecho não deve obviamente ser tomado ao pé da letra, pois faz parte do jogo parodiar a dicção acabrunhada das nossas classes dirigentes deprimidas pelo cotejo com os padrões metropolitanos de ordem e progresso. Meia dúzia de anos depois, nova variação sobre o mesmo tema: "Os mais velhos lembram-se muito bem, mas os mais moços podem acreditar: entre 1950 e 1979, a sensação dos brasileiros, ou de grande parte dos brasileiros, é de que faltava dar uns poucos passos para finalmente nos tornarmos uma nação moderna (...) Havia certamente bons motivos para afiançar o otimismo. A partir dos anos 80, entretanto, assiste-se ao reverso da medalha."8 Enfim, derradeira figura da procissão de milagres: "o excesso de liquidez

6. Folha de S. Paulo, 06.09.1987, p. A-38.

7. João Manoel Cardoso de Mello, "Conseqüências do neoliberalismo" in Economia e Sociedade, Revista do Instituto de Economia da UNICAMP, no. 1, 1992, p. 59.

8. João Manoel Cardoso de Mello e Fernando Novais, op.cit., p. 560. no mercado financeiro internacional, agora globalizado, permitiu em 1994 a implementação do Plano Real. Com a entrada maciça de recursos externos de curto prazo, engessamos o câmbio, abrimos a economia e multiplicamos as importações, freando a subida dos preços: nosso mais recente milagre."9 É claro que na mais recente acepção do termo milagre: quatro anos depois, o acordo falimentar com o FMI encerrava mais este episódio no capítulo das miragens milagrosas.

Se um leitor francês - que devo presumir interessado na crônica dos nossos desencontros com esse alto destino nacional, como logo mais se verá - folhear o número especial (257) que Le Temps Modernes dedicou ao Brasil em 1967, encontrará um outro registro revelador desta síndrome do encontro marcado. No artigo de abertura, ninguém menos do que Celso Furtado rendia-se ao que lhe parecia ser a evidência de um desastroso processo de "pastorização" do Brasil, que assim retornava ao marco zero na condição de "fronteira" de um novo arranjo supranacional ditado pela potência tutelar do golpe de 1964 . $\mathrm{E}$, no entanto, logo no ano seguinte à publicação deste artigo desenganado quanto ao nosso futuro congênito, declarava-se oficialmente aberta a temporada de mais um "milagre brasileiro", e novamente por força da exceção internacional e não da regra, como é da natureza dos milagres, que aliás se multiplicaram mundo afora naquela década de 70. O novo eclipse desse mítico futuro sobreveio logo adiante com a chamada (para abreviar) crise da dívida, e nele estamos mergulhados há duas décadas. Nestas circunstâncias, como era de se prever, retorna pontualmente à sua posição inicial o avesso do mito fundador

9. Idem, ibidem, p. 648. 
de que partimos. Assim, desde o início dos anos 90, Celso Furtado vem glosando por sua vez o tema da construção nacional interrompida e ameaçada, quando não cancelada de uma vez por todas: "Tudo aponta para a inviabilização do país como projeto nacional (...) Trata-se de saber se temos um futuro como nação que conta na construção do devenir humano."10 Se ainda houvesse alguma dúvida quanto à natureza recorrente do futuro que teima em não comparecer ao encontro marcado, basta relembrar os termos do que dizia o mesmo Celso Furtado há trinta anos no Temps Modernes: "A evolução mundial na segunda metade do século atual (...) pôs em evidência as incertezas que pairam com respeito ao futuro do Brasil. Existe um futuro para este país de dimensões continentais, cuja população em cinco anos terá superado os cem milhões, como projeto nacional auto-orientado?"11

\section{Titanic}

Se depender do diagnóstico fechado ainda outro dia pelo poeta e ensaísta alemão Hans Magnus Enzensberger, o grande futuro que nos estava prometido, com base obviamente na gigantesca vitalidade do país, simplesmente não chegou, nem chegará. "O Brasil é um país que acreditou que o futuro estivesse do seu lado e que trabalhava para ele (...) A bandeira brasileira é a única no mundo que ostenta o slogan Ordem e Progresso. É um slogan fantástico para um

10. Celso Furtado, Brasil, construção interrompida, SP, Paz e Terra, 1992, p.35.

11. "Brasil: da República Oligárquica ao Estado Militar”, in Celso Furtado (org.), Brasil, Tempos Modernos, São Paulo, Paz e Terra, 1977, p.2. país (...) O progresso para o Brasil dentro da modernização foi uma perspectiva virtual e sempre adiada."12 Demasia poética? É bom não esquecer que Enzensberger, justamente na condição de poeta e simpatizante histórico das revoluções nos trópicos, a começar pela cubana, pressentiu e profetizou em plena década de 70 o naufrágio próximo e conjunto do sistema soviético, da periferia emergente e do Welfare europeu, mergulhando a massa sobrante numa espécie de banalização do mal-estar na civilização capitalista vencedora. ${ }^{13}$ Como se vê, dos dois lados do Equador, a grande narrativa da convergência providencial do Progresso com a sociedade brasileira em construção já não convence mais, no juízo de um outro crítico literário, quer dizer, na opinião de um ensaísta que ainda considera a experiência artística o sismógrafo mais idôneo da história. ${ }^{14}$ Aliás, tampouco por acaso Enzensberger também acha que valeria para o Brasil o mesmo raciocínio hegeliano acerca do fim do Período da Arte. De fato, quando Hegel afirmou que a arte havia se tornado uma coisa do passado, não quis dizer evidentemente que não haveria mais obras de arte, pelo contrário, acrescentou no mesmo passo, que a partir de então, num movimento sempre recomeçado de auto-reflexão, ela adiaria o seu ponto final graças a uma crescente e exaustiva meditação sobre seus meios e fins. Do mesmo modo, segundo Enzensberger, o duplo "fim" do Brasil nunca chegou, como o da arte, está sempre sendo adiado. Mesmo porque, quando falamos do "fim", ele não

12. Entrevista a José Galisi Filho, Folha de São Paulo, 12.12.1999.

13. Como lembrado por Vinícius Dantas em artigo sobre o poema "O Naufrágio do Titanic", Jornal de Resenhas, 08.07.2000.

14. Roberto Schwarz, "Fim de século", in Seqüências brasileiras, São Paulo, Cia. das Letras, 1999, p. 161. O artigo em questão é de 1994. 
pode já estar aí, de corpo presente, pois senão não poderíamos falar dele: "no meu poema do naufrágio não formulo o 'fim', mas a iminência do fim (...) Enquanto ainda falarmos, este fim nunca deixará de recuar. Mas quem dará o testemunho do naufrágio, já que, como digo no poema, 'o fim é sempre discreto', já aconteceu, o iceberg já atingiu a estrutura do sistema?" Resta saber, portanto, o que virá depois da Ordem e do Progresso. Uma "outra desordem", responde o poeta, de mesma natureza, imagino, que o girar em si mesmo do fim da arte que nunca chegou. ${ }^{15}$

\section{Um futuro para o passado}

Deu-se então uma surpreendente reviravolta - resta ver até que ponto imaginária ou real. E ao que parece nos termos mesmos do presságio do poeta, já que ao seu ver o Brasil afinal teria relativizado "a dialética de ambos os pólos da Ordem e do Progresso, com a mistura de um pouquinho de progresso com regressão”. Pois justamente durante esta segunda década perdida de ajustes subalternos, ao longo da qual nos debatemos com nosso fim de linha nacional, nos vimos transformados numa espécie de paradigma, algo como uma categoria sociológica para o buraco negro da globalização - não uma remota África do humanitarismo à distância, na verdade um espectro ainda mais inquietante porque somos estritamente modernos, além de economicamente desfrutáveis as usual. De

15. Alguns anos antes dessas reflexões sobre o Brasil, Enzensberger já havia antecipado algo a respeito dessa "outra desordem" em suas visões da guerra civil, nas quais predomina a autodestruição dos perdedores enfurecidos com o desinteresse do capital em arrancar-lhes a pele. Cf. Guerra civil, São Paulo, Cia. das Letras, 1995. sorte que, na hora histórica em que o país do futuro parece não ter mais futuro algum, somos apontados, para mal ou para bem, como o futuro do mundo. Noves fora equívocos de parte a parte, uma chance histórica, do tamanho da ruptura de época que estamos vivendo, para trazer de volta a reflexão à periferia, no espelho da qual desta vez a metrópole se contempla, por certo que com a auto-complacência de praxe. Seja como for, não é trivial que o mundo ocidental confessadamente se brasilianize, depois de ter ocidentalizado a sua margem.

\section{Brazilianization}

Não saberia dizer ao certo quem lançou a tese da brasilianização do mundo. Como a expressão original indica, é mais do que provável que tenha sido nos Estados Unidos, à vista da inédita polarização social desencadeada pela contra-revolução liberal-conservadora da Era Reagan. Pelo menos é a essa nova máquina de gerar desigualdade e insegurança econômica crônica que se refere, por exemplo, a teoria de Edward Luttwak acerca da tiers-mondisation da América. ${ }^{16}$ Aqui e ali pipocam exemplos de subdesenvolvimento à brasileira, mas nada de sistematicamente novo.

É possível mesmo que o primeiro enunciado explícito da tese se deva a Michael Lind, para o qual a verdadeira ameaça pairando sobre o século XXI americano não é a escalada da violência étnica nos moldes da fragmentação balcânica, mas a brasilianização da sociedade: "por

16. Cf. Edward Luttwak, Le rêve américain en danger, Paris, Odile Jacob, 1995 (ed. Americana de 1993). 
brasilianização eu não entendo a separação das culturas pela raça, mas a separação das raças por classe. Como no Brasil, uma cultura americana compartilhada poderia ser compatível com um rígido sistema informal de castas, no qual a maioria dos que estão no topo é branca, enquanto a maioria dos americanos pretos e mulatos ficaria na base da pirâmide - para sempre."17 Uma outra característica "brasileira" deste quadro consistiria na dimensão horizontal da guerra de classes. No entender de Michael Lind, o domínio da oligarquia branca na política americana está na verdade sendo fortalecido e não ameaçado pela crescente polarização da sociedade; numa sociedade mais homogênea, a atual concentração exponencial de poder e riqueza certamente provocaria alguma reação da maioria; na atual situação porém, em que uma oligarquia confronta uma população diversificada e separada por raças, malgrado a cultura nacional comum, o ressentimento provocado pelo declínio econômico se expressa muito mais na hostilidade entre os grupos na base do que numa rebelião contra os do topo - tal como se viu no último motim em Los Angeles, quando pretos, hispânicos e brancos amotinados se voltaram contra os pequenos comerciantes coreanos em vez de marcharem sobre Beverly Hills. A brasilianização estaria patente ainda nos novos usos e costumes dessa overclass entrincheirada num país retalhado por enclaves privatizados, uma nação dentro da nação, desfrutando de uma sorte de extra-territorialidade que a imaginação política local costumava atribuir às oligarquias latino-americanas. A rigor, a novidade aqui reside

17. Michael Lind, The next american nation, NY, The Free Press, 1995, p. 216. Cf. o breve comentário de Serge Halimi no Le Monde Diplomatique de março de 1996, p. 12. no batismo brasileiro dessa revolução dos ricos e do futuro sombrio que ela estaria encubando. Salvo pelo qualificativo de brasileiro, o estado de verdadeira secessão em que viveriam as novas elites americanas, empenhadas em se desvencilhar dos laços políticos legais que ainda as atrelaria ao estorvo crescente representado por seus compatriotas de pés de chumbo, já havia sido identificado, por exemplo, por Robert Reich, só que à cata de circunstâncias atenuantes para o fenômeno - entre outros paradoxos, a relativa tranqüilidade política em que vem se operando tal desengajamento social -, como a obsolescência das fronteiras nacionais, acompanhada pela crescente capacidade demonstrada pela nova classe de "manipuladores de símbolos" de agregar valor nas cadeias relevantes nas redes globais de negócios. ${ }^{\mathbf{1 8}}$ (Quanto à provável marca brasileira deste novo separatismo da overclass americana, seria bom prevenir desde já o anacronismo: a desterritorialização das camadas superiores brasileiras é coisa muito recente, data a bem dizer da possibilidade atual de "dolarizar" seu patrimônio, pois só agora o dinheiro mundial ofereceu-lhe finalmente a oportunidade de evadir-se da prisão nacional.) ${ }^{\mathbf{1 9}}$

Pouco depois, Christopher Lasch aproveitaria a deixa e inverteria o raciocínio passavelmente apologético do futuro Secretário do Trabalho do primeiro período Clinton:

18. Cf. Robert Reich, L’Économie Mondialisée, Paris, Dunod, 1993, cap.22. (ed. Americana de 1991).

19. Ver a esse respeito os esquemas explicativos de José Luís Fiori e Carlos Lessa, entre outros críticos da economia política da globalização. Por exemplo, do primeiro, o artigo “Secessão", in Brasil no espaço, Petrópolis, Vozes, 2001; do segundo, "O desenvolvimento brasileiro depois do neoliberalismo", comunicação apresentada no Seminário O desenvolvimento: o fato e o mito, UFRJ, setembro de 1999. 
a equívoca meritocracia dos secessionistas na verdade representava uma ameaça para a vida civilizada num espaço cívico-nacional; ao contrário das massas temidas por Ortega y Gasset nos anos que antecederam a retomada da Grande Guerra, o perigo vinha agora da "rebelião das elites", enquanto a antiga subversão popular dissolvia-se no tímido conformismo de um processo de aburguesamento frustrado. ${ }^{20}$ Àquela altura, ainda nenhuma palavra mais explícita sobre o termo de comparação brasileiro que volta à cena - ou melhor, permanece em cena - mais recentemente no capítulo americano do ensaio de John Gray sobre os equívocos do "globalismo"21. A seu ver também não são nada desprezíveis os sinais de brasilianização da sociedade americana. Embora o estigma infamante não seja claramente assinalado, digamos que o mais abrangente deles aponta para o divórcio entre a economia política do livre-mercado e a economia moral da civilização burguesa, cujas instituições características, da carreira à "vocação" de tipo weberiano, a bem dizer deixaram de existir. Como resultado da remodelação da sociedade americana para se ajustar ao novo poder empresarial, a classe média desaburguesou-se ao mesmo tempo em que a maior parte da antiga classe operária industrial se reproletarizava, enterrando de vez o mito do progressivo embourgeoisement das camadas trabalhadoras no capitalismo organizado ao longo do pós-guerra. Numa palavra, a América não seria mais uma sociedade burguesa - tal como o Brasil, que nem mesmo chegou a sê-lo. Como um país periférico, nem mais nem menos, tornou-se uma

20. Cf. Christopher Lasch, The revolte of the elites. Tradução Brasileira: A revolta das elites, Rio, Ed.Ouro, 1995.

21. Cf. John Gray, False dawn, Londres, Granta, 1998, cap.5. sociedade partida em dois, "em que uma aflita maioria está espremida entre uma underclass sem esperanças e uma classe superior que recusa quaisquer obrigações cívicas". Aliás, ainda mais intensamente dividida do que uma sociedade mal-acabada do sul do continente, à vista da explosão, sem precedentes na história do país, do encarceramento em massa, paralelamente à evasão das elites emparedadas em comunas fechadas. A seu ver, o avanço da financeirização da riqueza num país, fraturado assim de alto a baixo, estaria arrastando os Estados Unidos a um "regime rentier, do tipo da América Latina".

Finalmente, um derradeiro registro insuspeito da propagação dessa percepção americana da brasilianização dos Estados Unidos pode ser encontrado na óbvia apreensão com que o filósofo Richard Rorty passou a admitir, na esteira do diagnóstico supracitado de Edward Luttwak, que o fascismo pode muito bem ser o futuro americano, ou algo do gênero de uma reação populista autoritária à atual divisão brasileira da América num sistema de castas sociais hereditárias, desfecho terminal que consolidaria de vez a despótica supremacia da oligarquia de feitio brasileiro identificada por Michael Lind. ${ }^{22}$ É bom lembrar que em meados dos anos 80, o pragmatismo filosófico de Rorty, subordinando a vontade de verdade e suas seqüelas doutrinárias ao desejo prático-institucional de solidariedade de grupo, autorizava-o a recobrir com algum verniz filosófico o "sucesso" das ricas democracias industrializadas do Atlântico Norte que estavam "dando certo" ou "funcionando", na acepção pragmática do termo. Como para um pragmatista à maneira de William James e Dewey, a verdade não é algo que corresponda à realida-

22. Cf. Richard Rorty Achieving our country, Cambridge, Harvard U.P., 1998. 
de, mas alguma coisa em que, para "nós” é bom acreditar como a liberal-democracia americana, por exemplo, cujo "sucesso" nada tem a ver com o fato de ser mais ou menos verdadeira, mais ou menos conforme aos princípios da natureza humana -, o consenso de uma comunidade passa a ser a peça central de uma construção baseada na vontade de alcançar o maior acordo intersubjetivo possível. Vistas as coisas por este prisma, compreende-se que a hora da verdade tenha chegado coma revelação da inédita dessolidarização nacional à brasileira, no caso a descoberta, entre outras fragmentações, da "secession of the successful", na frase de Robert Reich também citada pelo filósofo. Por definição, não pode haver "pragmatismo" (nada a ver com sua tradução brasileira barateada) que resista à quebra de algo como uma comunidade republicana entre explorados e exploradores: deslegitima-se assim uma economia internacionalizada "possuída por uma classe superior cosmopolita que não tem mais senso de comunidade com qualquer trabalhador em qualquer lugar do que os grandes capitalistas americanos do século XIX tinham com os imigrantes que manejavam as suas empresas”. Há mais ainda no capítulo das analogias brasileiras, desta vez porém, sem menção do modelo degradante. Qualquer brasileiro que tenha observado ultimamente a ascensão política entre nós do Partido Intelectual, e sobretudo seu modus operandi no Brasil privatizado de hoje, se sentirá em casa diante do quadro esboçado pelo filósofo americano frustrado no seu pragmatismo, cuja afinidade eletiva com a idéia republicana de nação não deixa aliás de fazer sentido. Pois Rorty reparte a overclass identificada por Michael Lind em dois pelotões de comando: no topo a plutocracia internacionalizada onde as decisões são tomadas; logo abaixo, os "manipuladores simbólicos" de
Robert Reich, os profissionais de instrução superior, cujo trabalho consiste em assegurar a realização suave e eficiente das decisões tomadas pelos primeiros, que por sua vez terão todo o interesse em conservar próspera e satisfeita tal camada social pois "eles precisam de pessoas que possam fingir ser a classe política de cada Estado-Nação individual. Para assegurar o silêncio dos proletários, os super-ricos terão de continuar fingindo que a política nacional pode algum dia fazer diferença”.

\section{A periferia na metrópole do capitalismo}

Que eu saiba, até agora ninguém se atreveu a sugerir que o coração do Império Americano com o tempo também se converterá em uma Índia, encimada por uma Bélgica. Todavia é isso mesmo que a tese da brasilianização dos Estados Unidos pretende insinuar. Mais exatamente, uma dualização tal da sociedade que só encontra paralelo no país clássico das clivagens inapeláveis, algo como o desfecho metafórico natural para sensação generalizada de "polarização dickensiana" nos centros emblemáticos da riqueza global, como no limiar da primeira industrialização, na visão romântica inglesa da sociedade dividida entre "duas nações" antagônicas. Seja como for, o fato é que o espantalho brasileiro acabou despontando no horizonte de um novo dualismo social on the rise. E o espectro de um equívoco, vistas as coisas do nosso ângulo. É que faz um bom tempo o antigo repertório da dualidade e seus derivados passou desta para melhor, além do mais irremediavelmente desmoralizado, conforme madrugava nos hoje remotos anos 60 o derradeiro capítulo da tradição crítica brasileira. Com toda razão aliás, pelo menos en- 
quanto variante das teorias funcionalistas da modernização, e suas respectivas políticas de acatamento subalterno dos padrões societários centrais, e conseqüente inclusão das barbaridades capitalistas locais no rol das anomalias do "atraso" e outros desvios. Mesmo assim - tal a regressão ideológica contemporânea - esse velho subproduto do evolucionismo modernista e seu cortejo de categorias polares, repartidas entre o campo dos avançados e o contra-campo dos retardatários, foi reposto em circulação, é verdade que menos como "teoria" do que como sinal de alarme ante à marcha do mundo no rumo de uma explosiva configuração "dual" entre integrados e descartados, além do mais hierarquicamente congelada. Apartação que a visão prevalecente no topo do mundo prefere encarar como uma disfunção - "regulações" residuais, inércias fundamentalistas - que o tempo se encarregaria de absorver. Tempo por sua vez funcionalmente espacializado - como nas antigas justaposições de setores sociais defasados —, numa derradeira corrida de adaptação à última encarnação do moderno. Isso no âmbito das agências e think tanks do poder imperial, desde que acendeu a luz vermelha do crescente mal-estar na globalização. De qualquer modo, dualismo à revelia, já que a simples admissão de uma sociedade global cindida entre vencedores e perdedores irreversíveis compromete a fraseologia da mundialização convergente e socialmente integradora. No plano local, porém, a ironia da reviravolta é bem mais grosseira: sob pretexto de modernização de um capitalismo em marcha desacelerada, veteranos da supracitada tradição crítica brasileira reinventaram, para fins de propaganda e marketing do novo mando, o mito do Brasil "errado", na verdade meio Brasil - ibérico, corporativo, imprevidente e tecnofobo - , emperrando o deslanche da outra metade, a vanguarda dos que estão se dando bem no país privatizado. Esse o velho acervo de equívocos e acertos que a brasilianization thesis veio revirar à sua maneira igualmente enviesada, tanto no Centro como na Periferia.

Nos tempos do grande embate com o raciocínio dualista na explicação das singularidades nacionais, um argumento recorrente costumava ressaltar seu cunho espacializante (como se recordou há pouco), tendente portanto a compartimentar as grandes dicotomias que travavam nossa formação, no limite uma renúncia ao dinamismo da crítica interessada em destacar a dimensão "moderna" do Antigo Regime e a parte de retrocesso no "progresso" da nova ordem. Até mesmo certas metáforas espaciais eram mal vistas, por bloquearem o impulso temporal da imaginação histórica: a ponto dos mais extremados considerarem duvidosa a distinção entre Centro e Periferia, já que o capitalismo era um só... Na verdade não era a visão espacial da sociedade dividida que ofuscava as promessas da dialética, mas algo como um fatal desconhecimento da territorialidade do poder capitalista pelo argumento materialista clássico. Em linha com o liberalismo econômico do século XIX, Marx "havia suposto que o mercado mundial operava por cima das cabeças e não através das mãos dos atores do Estado". ${ }^{23}$ Pois foi justamente a atual hipermobilidade do capital que veio

23. Giovanni Arrighi, "Século Marxista, Século Americano", in A Ilusão do Desenvolvimentos, Petrópolis, Vozes, 1997, p 309; publicado originalmente em 1990 na New Left Review, nº 179. Para essa retificação de percurso entre nós, e tudo o mais que isso implica para a esquerda na avaliação da miragem globalista quanto a uma tendência homogeneizadora de fundo na difusão mundial do mercado capitalista, ver por exemplo a Introdução de José Luís Fiori à obra coletiva Estados e Moedas no Desenvolvimento das Nações, Petrópolis, Vozes, 1999. 
lançar uma nova luz sobre esse ponto cego de nossa tradição crítica, não por acaso engolida pelo mito economicista da globalização enquanto transbordamento natural dos mercados nacionais interdependentes. Uma tal liberdade de movimento, ontem como hoje, simplesmente não seria possível na ausência de uma multiplicidade hierarquizada de juridições políticas: foi preciso um fiasco sem precedentes na história de nossa intelligentsia para que se redescobrisse essa verdade elementar do moderno sistema mundial enquanto modo de governo e acumulação. Assim sendo, não surpreende que a abordagem dualista por certo sempre suspeita de sobrecarga ideológica, ora a favor, ora contra - tenha ganho uma segunda juventude, graças justamente à centralidade da espaciliazação capitalista na atual dinâmica mundializada da acumulação.

Ao contrário do que apregoa o senso comum globalitário - tanto à esquerda como obviamente à direita acerca da imaterialidade da nova riqueza capitalista e a respectiva desimportância do "lugar", a atual pulverização da atividade econômica pela transnacionalização das cadeias produtivas globais, seria materialmente inviável sem uma correspondente centralização territorial, mais especificamente uma hiperconcentração da propriedade dos meios de produção e consumo em nós estratégicos exigidos por uma nova lógica de aglomeração. Essa, a matriz material-espacial da Dualização cuja ressurreição surpreendente no coração mesmo do sistema está nos interessando identificar, está claro que à luz da nossa ambígua dualidade por assim dizer de raiz, como é o caso de uma periferia originária, gerada na primeira expansão colonial que veio a ser o big bang de nascença da economia-mundo capitalista. Não será preciso acrescentar que o locus dessa concentração contínua de comando econô- mico estratégico, que esse palco mais ostensivo da nova dualidade, é a cidade, mas uma cidade antes de tudo mundializada pelo capital e atravessada por uma divisão social inédita entre populações imobilizadas nesses verdadeiros containers urbanos e a nova classe dominante em estado de secessão, mas nem por isso podendo dispensar a espécie de mais valia bruta extorquida dos sedentários. Pois bem: esse fosso crescente entre força de trabalho degradada e descartada e operadores hipervalorizados nas cidades estratégicas de um sistema mundial já em si mesmo altamente desigual e hierarquizado, além do mais percebido na sua mais impressionante manifestação socioespacial, também se apresentam como uma outra evidente confirmação de algo como uma segunda periferização do mundo. ${ }^{24}$ É nessas cidades divididas que se manifesta o novo dualismo americano que de uns tempos para cá vem sendo equiparado à obscena polarização brasileira. ${ }^{25}$

24. Tomando alguma liberdade com o argumento bem conhecido de Saskia Sassen, que obviamente estava reprisando. Cf da autora, o capítulo IX de The Global City, Princeton UP, 1991, e As Cidades na Economia Mundial, São Paulo, Studio Nobel, 1998, capítulos I e VI.

25. Só para confirmar, no mesmo Robert Reich da secessão dos "manipuladores de símbolos" e seu desengajamento em relação às demais camadas da população nacional: "numa escala muito maior, o esquema da secessão se apresenta nas grandes cidades americanas. Com efeito, já no início dos anos 80, a maioria das aglomerações se encontravam separadas em duas zonas; uma reagrupa os 'manipuladores de símbolos' cujos serviços conceituais estão vinculados à economia mundial; a outra, os prestadores de serviços pessoais, cujos empregos dependem dos primeiros", op.cit., p 253. Enquanto isso, vão rareando os blue collars: Pittsburgh é um bom exemplo: aqueles assalariados ditos rotineiros, na classificação tripartite de Reich, ocupavam nos anos 50 a metade dos empregos na cidade, porém mal alcançavam $20 \%$ em meados dos anos 80 , ao passo que as duas outras categorias teriam avançado sobre esse terreno desocupado, numa cidade que nesse meio tempo se tornara a terceira concentração americana de headquarters corporativos. Enfim vale o registro sem novidade, embora não fosse tão óbvio assim há dez anos atrás da parte de um membro do establishment: o ideal urbano dessa nova raça meritocrática viria ser o de uma fortaleza high-tech introvertida mesclando funções residenciais, de negócios e consumo conspícuo, sem risco de contacto direto com o mundo exterior, em particular com a outra parte da cidade. 
Foi assim que desde o início da Era Reagan, Los Angeles começou a ser vista como grande experimento da apartação social característica do novo regime urbano, induzido, no caso, pela transnacionalização do espaço econômico norte-americano e suas brutais assimetrias concentradoras e centralizadoras. Por essa época, Edward Soja, por exemplo, principiou a falar de cidade dual pós-fordista, espacialização de uma reestruturação produtiva não por acaso deflagrada por uma completa redisciplinarização da força de trabalho (juntamente com a dos capitais menos eficientes e a reorientação privatista dos fundos públicos), mediante uma reciclagem ocupacional que polariza cada vez mais o mercado de trabalho, por sua vez inflacionado pela imigração maciça e pelos empregados em tempo parcial e do sexo feminino; o que foi resultando, a seu ver, numa verdadeira periferização do Centro: encolhimento das camadas intermediárias, no topo a oligarquia do capital corporativo, encimando "o maior bolsão de trabalhadores imigrantes mal pagos e mal organizados do país", de sorte que afinal o Centro também se tornou Periferia, na medida mesmo em que a "cidadela empresarial do capital multinacional apóia-se com rematada agilidade em uma base cada vez mais ampla de populações estrangeiras"26 . O retrato mais famoso da dualização de Los Angeles se deve, como sabido, a Mike Davis. Nela já não seria mais possível separar a grande afluência dos ricos e poderosos do desamparo e desmoralização das populações proletarizadas, ao confinamento das quais - dos guetos

26. Edward Soja, "Tudo se junta em Los Angeles", in Geografias pósmodernas, Rio de Janeiro, Jorge Zahar, 1993, p 262. Cf ainda do mesmo autor, "Poles apart: urban restructuring in New York and Los Angeles", in Mollenkopf e Castells (orgs.) Dual City - restructuring New York, New York, Russell Sage Foundation, 1991. negros de sempre, inchados pela mão de obra imigrada, à proliferação das instituições carcerais - corresponde as famigeradas gated communities, a fortificação das camadas privilegiadas, privatizando lugares públicos e militarizando o espaço construído ${ }^{27}$. Logo depois foi a vez de Nova York tornar-se outro caso exemplar de ordem social urbana com duas velocidades - a cidade a um tempo global e dual por excelência, na análise bem conhecida de Saskia Sassen e demais teóricos do sistema mundial de cidades $^{28}$.

Dito isso, é bom não esquecer que a Cidade Dual é um tópico clássico da sociologia urbana americana. (Para não remontar ao Livro IV da República, no qual o filósofo também relembra que toda cidade está dividida em duas cidades, a dos ricos e a dos pobres, além do mais em guerra uma com a outra, sendo por isso um erro grave tratá-las como constituindo um só Estado). O contraste entre opulência e pobreza coexistindo em um mesmo espaço urbano sempre gerou desconforto em cientistas sociais e opinião pública em geral. Depois de recordar essa tradição e ressaltar a carga emocional e política da abordagem dualista por assim dizer intuitiva - que pelo menos tinha o mérito de introduzir alguma tensão na visão organicista da cidade como uma comunidade integrada -, Manuel Cas-

27. Cf. Mike Davis, A Cidade de Quartzo, São Paulo, Scritta, 1993. Ver a respeito o artigo de Loïc Wacquant, "Un laboratoire de la polarisation", Le Monde Diplomatique, abril 1998 p. 28.

28. Cf p.ex. Paul Knox e Peter Taylor (orgs.), World Cities in a WorldSystem, Cambridge, UK, 1995, para uma revisão e atualização da "World Cities hypothesis" de John Friedmann (1982), segunda a qual o novo regime das desigualdades urbanas poderia desde então ser apanhado pela metáfora dual da "cidadela" e do "gueto", imagem que aliás foi derivando para a da "ampulheta" sugerida por Peter Marcuse, ao propor seu próprio modelo de "quartered city". 
tells, por sua vez, também afirma que já não é mais esse o dualismo urbano em ascensão, mas uma nova dualidade (se ainda for adequada a expressão) decorrente, como era de se prever, do processo de reestruturação e expansão da chamada economia informacional, como denomina, e sublima, o modo de desenvolvimento capitalista baseado no "trabalho com informação"29. Mais especificamente, no que consiste afinal, para o mais recente e enciclopédico ideólogo da globalização a nova forma do dualismo urbano ${ }^{30}$ Como estamos lidando com um notório protagonista de uma daquelas "viagens para dentro" estilizadas por Edward Saïd, a saber, a imigração intelectual, em princípio "adversária" ou "irônica", da periferia (semiperiferia mediterrânea, no caso) para o coração do império, a curiosidade não parece descabida ${ }^{31}$.

Antes de mais nada, quem diria, trata-se da expressão de uma defasagem, como nos bons tempos do progressismo funcionalista: no caso, estaria na berlinda o descompasso entre o envelhecimento do trabalho rotineiro e o

29. Na boa fórmula de Marcos Dantas, na qual as coisas são chamadas por seu nome; por exemplo, a criação de barreiras ao acesso à informação ao contrário da apologética corrente, por definição recurso vital, por isso mesmo socialmente produzida - no processo de realização do valor, e sua correspondente apropriação rentista. Cf. Marcos Dantas, Trabalho com Informação, UFRJ, 1994, no prelo (Editora Boitempo). Se o Autor estiver na direção certa, como parece, é bem provável que à nova centralidade do trabalho com informação correspondam novas periferias na divisão internacional do comando político e econômico sobre a propriedade intelectual: no centro geopolítico do processo de trabalho informacional, as cidades do capital-informação, tão dualizadas quanto a polarização induzida no interior mesmo das redes empresariais, a um tempo altamente concentradas e descentralizadas.

30. Cf p.ex. Manuel Castells, The Informational City, Oxford/Cambridge, Blackwell 1989, pp.172-228; Mollenkopf e Castells, op.cit., pp. 399-418.

31. Cf. Edward Saïd, Cultura e Imperialismo, São Paulo, Cia. das Letras, 1995, p. 306. crescimento do setor dito pós-industrial, transição além do mais marcada pelo desmonte da mediação estatal nas relações entre capital e trabalho, e situada de preferência nos pontos nodais da geografia econômica, as áreas metropolitanas de maior concentração das atividades ditas knowledge-intensives. Dualismo refere-se assim, em primeiro lugar, a uma estrutura social altamente estratificada e segmentada, decomposta não só em trabalho valorizado e trabalho degradado, mas também filtrando e expulsando muita gente dessa dinâmica binária. Nessas circunstâncias, a cidade dual também pode ser vista como a expressão urbana de um processo de crescente diferenciação no mundo do trabalho, dividido em dois "setores" básicos: um setor informal, que não se deve confundir com pobreza urbana, nem com atividades de mera sobrevivência, e um outro de economia formal, obviamente information-based. Duas metades entrelaçadas por um sem número de relações simbióticas, mas nem por isso reciprocamente excludentes, ainda que funcionalmente articuladas. Do que resulta enfim, como era de se esperar, um contínuo estrangulamento dos níveis intermediários, conformando um sistema cada vez menos aberto à mobilidade ocupacional: no topo high-tech dos serviços avançados, uma elite funcional e socialmente self-contained, cuja auto-suficiência não implica em reclusão mas circulação desimpedida em incontáveis rede transfronteiras de acumulação de todo tipo de poder social; na base, um outro pacote, o localismo do trabalho desestruturado e portanto segmentado numa miríade de arranjos defensivos. De sorte que - sempre na opinião de nosso Autor - , essa dualidade estrutural não engendra dois mundos diferentes, longe disso, mas uma variedade de universos sociais, cuja figuração espacial se caracteriza pela segregação, di- 
versidade e hierarquia. Algo como uma dualização meritocrática: pois é a segmentação do mercado de trabalho que produz o dualismo social, simplesmente sancionando a capacidade de grupos e indivíduos de ingressar nas avenidas que conduzem às novas fontes de riqueza. No limite, reconhece Castells, em caso de "bloqueio" das "trajetórias tecnológicas", a sociedade informacional pode de fato se transformar numa sociedade realmente dual, sem que haja no entanto nenhuma razão para que isso necessariamente venha a ocorrer; assim, apenas aparentemente a chamada sociedade em rede está se dualizando, pois bem lá no fundo o que o trabalho informacional desencadeou mesmo foi um processo mais fundamental de desagregação do trabalho, e é isso que define sua estrutura em rede ${ }^{32}$. Daí o seu dinamismo, arrematando a apologia: a exclusão social é um processo e não uma condição (no que estamos todos de acordo ...), sendo assim mutáveis suas fronteiras, "os incluídos e os excluídos podem se revezar no processo ao longo do tempo". ${ }^{33}$ (Avançando o sinal, veremos mais adiante, se uma tal alternativa, caso exista de fato, não comportaria uma versão "periférica").

Tudo somado, onde então a brasilianização da cidade dual americana, versão Castells? Na acepção em que a tomou Michael Lind, exatamente onde a deixamos, é claro que nos seus próprios termos, a saber: segundo nosso doutrinário da Sociedade em Rede, uma das conseqüências fundamentais da cidade dualizada diz respeito à formação das classes sociais. Aqui a novidade: esta formação só se completaria no polo dominante, a nova classe profissional-gerencial que

32. Cf. Manuel Castells, The Rise of The Network Society, Blackwell, 1986, pp. 273,279 .

33. Id., The End of Millenium, Blackwell, 1998, p 73. opera no âmbito mesmo daquela esfera oligárquica idenficada por Michael Lind, à qual se contrapõe não uma outra classe subalterna solidamente ancorada na privação, porém a desarticulação social permanente dos estilhaços sociais do mundo desestruturado do trabalho. Seja dito entre parênteses que uma tal projeção não deixa de repercutir uma sugestiva hipótese de alguns sociólogos franceses: primeiro, que a burguesia ainda existe sim, e mais, com a plena consciência de constituir um grupo transnacional (seu cosmopolitismoé de nascença), empenhada na perpetuação de dinastias patrimoniais, permanentemente mobilizada por detrás da fachada operacional dos managers e investidores institucionais enquanto supostos novos donos do mundo (pelo menos na França, faz-se de tudo para ocultar os interesses vinculados a tal ou qual patronímico à sombra de organogramas abstratos, dando a entender uma espécie de difusão sem limites da propriedade do capital), tudo resumido enfim no culto ostensivo do "l'entre-soi", visível na marca registrada dos beaux quartiers semeados pelos sítios mundiais do consumo conspícuo; segundo, que só essa burguesia, multinacional como os antigos clãs aristocráticos, é uma verdadeira classe social, à qual se filia em ordem dispersa e subordinada os indivíduos avulsos das camadas intermediárias que se tomam por "sujeitos", quer dizer, empresários de si mesmos, "atores" de sua própria autoconstrução etc; enfim, rente ao solo, nos meios populares de ontem, a ausência do coletivo, corroído pelo individualismo negativo das desafiliações de massa, na fórmula consagrada de Robert Castel, desgarrando-se do enquadramento das antigas instituições da sociedade salarial ${ }^{34}$.

34. Cf. Michel Pinçon e Monique Pinçon-Charlot, Sociologie de la Bourgeoisie, Paris, La Découverte, 2000. 
Pois bem: completando o panorama "brasileiro" involuntário (a propósito: veremos mais à frente que "individualismo negativo" pode muito bem ser conosco mesmo), Castells evoca à certa altura ${ }^{35}$ suas reminiscências dos tempos de estudioso da "cidade dependente" na América Latina $^{36}$, para descartar é claro qualquer contaminação da mal reconhecida polarização social de hoje nas metrópoles globalizadas pelo equívoco de ontem, o "mito da marginalidade", urbana ou não, nas economias de industrialização tardia do continente sul-americano, recordando o título da súmula com que Janice Perlman por assim dizer arrematou o debate. Não custa lembrar que, àquela altura, Castells alinhava com os adversários da teoria que identificava na massa marginal produzida pela modernização em curso na América Latina um exército industrial de reserva de tal modo excessivo que já se tornara a rigor inintegrável, constituindo-se num imenso reservatório de anomia e apatia política: por mais que pudessem ameaçar a ordem estabelecida, eram economicamente irrelevantes. Pelo contrário, como tantos outros, era dos que sustentavam a funcionalidade da "margem", para além é claro do mero rebaixamento do custo da força de trabalho; mais especificamente, também era de opinião - ainda no final dos anos 80 - que a dualização que importava era a distinção entre os setores formal e informal da economia, sendo o segundo tão "moderno" quanto o primeiro, além é claro de majoritário. Àquela altura se apoiava num Alain Touraine que também não existe mais ${ }^{37}$, para o qual

35. P.ex., Dual City, ed.cit, pp.409-410.

36. Cf. p.ex. The City and the Grassroots, Berkeley, University of California Press, 1983, pp.173-212.

37. Cf. Alain Touraine, La Parole et le Sang, Paris, Odille Jacob, 1988. na América Latina daqueles tempos de autoritarismo e industrialização em marcha forçada - sendo o subemprego muito mais que a simples margem do emprego formal seria o caso de se voltar a falar em dualização, mas não em marginalidade, sobretudo num momento (anos 80) em que a Europa desempregada parecia estar menos distante da América Latina. Por que não conjeturar livremente? Mais um passo e estaria confirmada a partir de então a idéia que que todo sistema social seria hoje comandado por uma lógica dual. Acresce que naqueles primeiros tempos do "ajuste" latino-americano ao padrão geomonetário deflagrado pelo ditakt politico do novo dinheiro mundial (o parâmetro imperial do dólar-flexível), em que a integração global subalterna já se fazia acompanhar de uma igual desintegração nacional, na conhecida fórmula de um veterano como Oswaldo Sunkel, voltou-se a falar, no continente, de um "novo dualismo", fosso aberto pelo crescente descompasso entre modernização e modernidade, dessa vez porém um déficit inteiramente contemporâneo que estaria nos assemelhando à sociedade de dois terços dos países industrializados - na época, uma hipótese ainda otimista. ${ }^{38}$ Tudo isso não obstante, parece claro que aquelas velhas confusões acerca dos integrados e dos outsiders parecem repetir-se a propósito da redundância social dos chamados excluídos de hoje. Mesmo assim, deu-se de qualquer modo uma reviravolta, como era de se prever. Como aliás pudemos perceber, a globalização segundo Manuel Castells respira o mesmo ar de família das finadas teorias da modernização à cata de patologias

38. Cf. Norbert Lechner, “A modernidade e a modernização são compatíveis?”, Lua Nova, São Paulo, n²1, 1990. 
superáveis nas sociedades periféricas, daí sua hesitação diante do diagnóstico da dualização. No fundo acredita numa convergência mundial a caminho e, com o tempo, o espantalho da brasilianização do antigo Primeiro Mundo (outrora uma sociedade relativamente homogênea, pelo menos na Europa, mesmo que pelos breves e excepcionais 30 anos do auge fordista) acabará sendo sugado pelo buraco negro do Quarto Mundo - se é que esse último já não se tornou por sua vez eufemismo para "brasilianização" enquanto sinônimo de integração perversa (como se diz) na chamada sociedade da informação. De um modo um tanto convencional, para Castells, além do mais, apenas certas áreas empobrecidas da América Latina estariam condenadas à marginalização reencarnada pelo Quarto Mundo, do confinamento territorial de populações sem valor econômico à predação do próprio povo como política de Estado. No Brasil brasilianizado, todavia, o que está mesmo em curso é uma alternativa que se poderia chamar de africanização de elite. ${ }^{39}$

Dando um balanço numa década de estudos balizados pelo paradigma das cidades mundiais - um paradigma de inequívoca intenção crítica, diga-se de passagem, apto a tornar visível e politicamente abordável o locus da inédita polarização cavada pela reconfiguração em curso no alto comando do sistema capitalista mundial —, um de seus formuladores pioneiros, como lembrado páginas atrás, John Friedmann, também não deixou de registrar a curva apologética descrita pelo teórico/consultor-fluxo

39. “A 'africanização' do Brasil resulta da ocorrência simultânea de quatro processos: desestabilização macroeconômica, desmantelamento do aparelho produtivo nacional, esgarçamento do tecido social, deterioração política e institucional”, Reinaldo Gonçalves, "Capital Estrangeiro, Desnacionalização e Política Externa”, praga, nº 9, São Paulo, HUCITEC, 2000, p.75.
Manuel Castells ${ }^{\mathbf{4 0}}$, o real percurso afinal de sua "viagem para dentro", nos termos estilizados de Saïd: nos seus primeiros escritos da década, malgrado seu crescente êxtase high-tech, a identificação dos "espaços-de-fluxos" desterritorializados, e por isso mesmo de acesso ultra-seletivo aos poucos protagonistas do jogo da acumulação transfronteiras, pelo menos dava a entender, ao sublinhar o crescente disempowerment dos barrados na entrada, que um outro mais poderoso dualismo de incorporação/exclusão estava em vias de ser perenizado; porém, a partir da obra coletiva sobre a aparente dualização de Nova York, nosso Autor teria inaugurado uma sorte de "desconstrução" (sic) da hipótese da sociedade polarizada, atribuindo à clivagem ocupacional, de gênero, raça e etnicidade, a principal fonte da subordinação dos subalternos, celebrando-lhes enfim, a "diferença"41. Em suma, a "viagem para dentro" de nosso teórico-fluxo, ao contrário do discurso edificante de Saïd quanto ao seu caráter adversário, provou ser antes de tudo afirmativa, na rota oposta da multidão de imigrantes pós-coloniais, cuja força de trabalho reterritorializada em casa alheia Saskia Sassen contrapôs às torres do capital corporativo nas cidades imperiais de

40. Num acesso de inesperada clarividência, nosso ideólogo do Estado-emRede, (entre outras amenidades características do admirável mundo novo da globalização), depois de especificar o que faz de um "lugar" um lugar - como o bairro operário de Belleville em Paris, onde residiu como jovem foragido do franquismo e futuro sociólogo althusseriano - , admite que hoje em dia, quando o revê, o faz na condição de homem-fluxo, membro titular do circuitos mundiais de riqueza e poder informacional. Cf. The Rise of the Network Society, ed.cit, p.423. Fluxo dispondo de um nó estratégico na Califórnia, aliás localização imperial de um curioso ninho tucano de experts em "ajustes" ao nosso "changing world", com Cadeira Joaquim Nabuco bancada pelas altas finanças e tudo o mais que daí se segue em matéria de livre pensamento.

41. Cf. John Friedman, "Where we stand: a decade of world city research", in Knox e Taylor (orgs.), World Cities in a World-System, ed.cit., p.33. 
hoje $\mathrm{e}^{\mathbf{4 2}}$. Dito isso, seria preciso acrescentar, não sem tempo, que a Cidade Global de Saskia Sassen, dualizada ou brasilianizada, não é apenas, e nem longe, uma narrativa complacente e compassiva de exclusão. Pelo contrário, os "outros" territorializados pelo novo regime urbano não só não são trivialmente dispensáveis - como demonstra uma recente mobilização nacional dos "janitors" 43 e demais "serviçais" do capitalismo corporativo place bounded, queira ou não queira - , como estão transformando a cidade dualizada num território contestado. Portanto narrativa de um confronto balizada pela revelação - à contra-corrente da retórica dos fluxos ilocalizáveis — de uma outra centralidade do lugar e da produção, seja essa última representada pelos trabalhadores de uma zona especial de exportação ou simples faxineiras e secretárias em Wall Street.

Antes de passar adiante nessa cartografia brasilianizada da polarização mundial em ascensão, não seria demais recordar que uma tal ressurreição do fantasma da cidade dualizada pode muito bem lastrear providências pró-sistêmicas. Daí algumas reticências. Por exemplo: "Cabe perguntar se a característica mais específica dessas cidades não seria tanto a dualização extrema e sim o extremo contraste social e sua extrema visibilidade, por

42. Cf. Saskia Sassen, Globalization and its Discontents, New York, New Press, 1998, pp.XXX-XXXI. Pós-colonial evidentemente numa outra acepção de imigração, pelo alto no caso. Como Arif Dirlik gosta de observar, uma outra maneira de embandeirar a chegada glamourizada dos intelectuais da Periferia ao mundo acadêmico do Centro. Cf. Arik Dirlik, The Postcolonial Aura, Boulder, Westview Press, 1997.

43. Veja-se a matéria editorial sobre a greve de zeladores, porteiros, faxineiras, etc, em abril de 2000 nos Estados Unidos, na International Socialist Review, $\mathrm{n}^{0} 72$, junho-julho/2000. E também o filme Bread and Roses de Ken Loach, certamente um filme bem diferente quando revisto à luz desses baixos circuitos do capital por detrás das funções de comando. causa da presença da riqueza extrema e da forte midiatização desses espaços. Essa intensidade do contraste, sentida pelos moradores, seria também a fonte das tensões sociais e da escalada da violência que é costume associar-se à dualização. Em compensação, em termos absolutos, a polarização mais forte não seria necessariamente aquela observada nessas cidades, mas seu núcleo dominante estaria em oposição aos segmentos dominados da economia, aos lugares de exclusão, aos lugares onde o lucro nasce da desestruturação". ${ }^{44}$ Noutras palavras: embora a tendência seja mesmo a escalada no aprofundamento dos extremos, acelerando inclusive a laminagem do já declining middle, subsiste um apelo, implícito na imagem da cidade dual, à espetacularização da coesão social ameaçada. Nesse mesmo passo, uma boa mídia se encarregará — como é da natureza do veículo - de despolitizar a desigualdade, agora sim assustadora. Numa cidade convenientemente repartida entre bárbaros e civilizados, as divisões acabam se resumindo a oposições anódinas entre violência e convivência, solidariedade e egoísmo, etc. Nesse caso, a ênfase dual dramatiza uma certa sensação difusa de crise, cujo de calda propiciará então uma intervenção estratégica na gestão da cidade - no caso, uma gestão de tipo empresarial, destinada a substituir a imagem problema de uma

44. Edmond Préteceille, "Cidades Globais e Segmentação Social”, in Luis César de Queiróz Ribeiro e Orlando Alves dos Santos Junior (orgs.), Globalização, Fragmentação e Reforma Urbana, Rio de Janeiro, Civilização Brasileira, 1994, p.86. Numa intervenção mais recente, o mesmo Préteceille volta a insistir com dados novos que a metrópole parisiense não se encaixa inteiramente no modelo da cidade global, com duas velocidades, polarizada entre um novo proletariado cada vez mais desqualificado e o topo dos serviços avançados prestados aos centros empresariais de comando das cadeias produtivas mundiais. Cf. "Divisão Social e Desigualdade: Transformações Recentes na Metrópole Parisiense”, in Luis César de Queiróz Ribeiro (org.), O Futuro das Metrópoles, Rio de Janeiro, Revan, 2000. 
cidade dualizada pela imagem competitiva de uma cidade reunificada em torno dos negócios da máquina urbana de crescimento $^{45}$. É nesse momento de virada e exorcismo da dualização que nosso autor-fluxo se converte em expert-consultor ${ }^{\mathbf{4 6}}$. Apelando, entre outras panaceias antidualistas, e, portanto, geradoras de consensos óbvios (quem não é pela paz? pela civilidade?), para um certo sexto sentido cívico denominado "patriotismo de cidade". Convenhamos que a providência é astuciosa, sobretudo quando se trata de vender pacotes a municipalidades aspirantes a algum enclave de cidade global. ${ }^{47}$ Pois como vimos, é justamente no território contestado destas últimas as reais, é claro - que uma crescente e degradada força de trabalho, além do mais feminizada e etnicizada, vem acossando seus patrões globais numa arena para além de qualquer referência a uma comunidade nacional ou coisa que o valha, et pour cause. O marketing de um sucedâneo de "pátria" faz então todo o sentido, bem como a alegação esperta de que a globalização — se facilitar — dualiza as cidades, cada vez mais parecidas com as "cidades partidas" brasileiras.

45. Para uma crítica da fraseologia dualista da "cidade partida", cf.Luis César de Queiróz Ribeiro, “Cidade Desigual ou Cidade Partida?”, in Luiz César de Queiróz Ribeiro (org.), O Futuro das Metrópoles, ed.cit, pp.63-64. Para uma crítica mais abrangente do novo modelo de gestão urbana denominado genericamente "planejamento estratégico", ver Otília Arantes, Carlos Vainer e Ermínia Maricato, A Cidade do Pensamento Único, Petrópolis, Vozes, 2000, cujo argumento estou resumindo. A noção "máquina urbana de crescimento", retomada por O. Arantes, remonta aos escritos pioneiros de Harvey Molotch, cf. op.cit., p. 25 e ss.

46. Cf. Jordi Borja e Manuel Castells, Local y Global. La gestion de las ciudades en la era de la información, Madrid, Taurus, 1997, obra da qual um capítulo foi publicado na revista Novos Estudos, CEBRAP, n 45, 1996, "As cidades como atores políticos".

47. Como explicam os autores de A cidade do pensamento único.

\section{Fraturas francesas}

Há meio século atrás, não foi pequena a contribuição francesa para a consolidação e difusão de uma outra grande narrativa fundadora de uma nacionalidade periférica como a brasileira. Exatamente algo como a intuição recorrente de uma "dualidade básica" - para falar como Inácio Rangel - cujas metamorfoses de época exprimiriam a lógica mais recôndita de nossa matéria social específica. De resto, nada que um brasileiro, letrado de preferência, não soubesse muito bem, mesmo nas formulações mais arrevesadas. Só para constar, recorde-se que sempre nos sentimos uma "imundície de contrastes", como dizia Mário de Andrade. Uma sensação a um tempo coletiva e de classe. Sobretudo de classe. Só à elite pensante e governante cabia o privilégio do ser-dividido entre duas fidelidades, ao pequeno mundo das segregações coloniais e ao grande mundo das metrópoles sucessivas do Império de turno, alternância ora formalizada e filtrada pelo juízo crítico, ora congelada nas fixações ideológicas da consciência amena do "atraso", hoje rediviva, esta última, com a cultura do contentamento gerada pela marola cosmopolita da globalização. Assim, a propósito do envelhecimento precoce das cidades brasileiras, Lévi-Strauss foi dos primeiros a bater na tecla de nossa constituição dúplice. Aliás, revelando meio sem querer aos brasileiros que essa caducidade de nascença corroendo nossos surtos modernizantes - como era de se esperar de um país de veleitários - , contrariava a certeza mítica do encontro providencial com o Progresso, reforçando em conseqüência o avesso não menos mitológico de tal certeza, a saber, que essa defasagem perene estava por seu turno na raiz da frustração permanente daquela visão do País do Futuro. Mais adiante foi a 
vez de Lucien Febvre felicitar-se por ainda poder assistir no Brasil ao espetáculo original oferecido pela superposição ao vivo de diversas idades históricas num só país. A seguir Roger Bastide nos definiu por um contraste por assim dizer atávico, sublinhando ora a crispação dos elementos antagônicos, ora, à maneira de Gilberto Freyre, a harmonização ou atenuação dos contrários. Mas foi sem dúvida Jacques Lambert quem cunhou o clichê mais duradouro a cerca da singularidade de nossa civilização, o cromo dos dois brasis justapostos, a nação dividida em duas partes isoladas por um abismo de séculos, o país urbano numa metade, na outra, ainda em vigor, os avatares da Colônia ${ }^{\mathbf{4 8}}$. Tudo isso observado e dito por comparação óbvia com a relativa homogeneidade social de uma nação européia, cuja organicidade por seu turno nos servia de norma crítica e modelo a ser alcançado. Foi assim inclusive durante todo o ciclo que a seguir se desenrolou acompanhado por uma consciência dramática do subdesenvolvimento, nos termos da periodização adotada por Antonio Candido: a superação daquela dissociação intolerável entre os happy few incorporados às modernas formas de produzir e consumir e a grande massa das populações relegadas também foi entrevista no horizonte de uma homogeinização social à européia, movida a difusão do progresso técnico e pressão dos assalariados para aumentar sua participação no incremento do produto. Dizer que a coesão social resultante dessa dinâmica distributiva do finado ciclo fordista nos países centrais se encontra seriamente ameaçada, é dizer pouco. O tempo dirá se terá sido uma demasia desarquivar a imagem assustadora da sociedade dual do subde-

48. Cf. Paulo Eduardo Arantes, Sentimento da Dialética na Experiência Intelectual Brasileira, São Paulo, Paz e Terra, 1992, p.24. senvolvidos, novamente na berlinda a propósito desses novos "tempos da exclusão", como se diz a torto e a direito no debate francês.

Não saberia dizer se o neologismo brésilianisation chegou a ser empregado alguma vez quando a opinião francesa se deu conta de que, mesmo num dos países mais prósperos da Europa, a nova riqueza estava produzindo novos pobres em proporções nunca vistas, bem como regiões industriais sinistradas, zonas rurais desertificadas, subúrbios guetoizados, etc. Como também se começou a falar de um Quarto Mundo de marginalizados, podemos supor que só faltaria o acréscimo de mais uma palavra emblemática no vocabulário da exclusão - por enquanto sem aspas. Chegou-se no entanto bem próximo, porém em termos continentais: malgrado as óbvias diferenças estruturais entre a pobreza urbana latino-americana, velha de meio século, e a recente experiência francesa da precarização social, não faltou quem começasse a reparar que não era inteiramente arbitrária a transposição européia de conceitos forjados há 30 anos por especialistas franceses em América Latina, convergindo inclusive - crítica a menos - discursos e políticas correspondentes: "tendência sistemática à dualização do mundo social, oscilação entre populismo e miserabilismo, tentação das interpretações psicossociais que culpabilizam as vítimas". ${ }^{49} \mathrm{O}$ fato é que há mais ou menos uma década, a percepção francesa da "exclusão" e sua repartição entre o "dentro" e o "fora", começou a se ver espelhada na polarização entre o "alto" e o "baixo" da nova underclass americana e na dualidade centro/periferia da velha marginalidade latino-america-

49. Didier Fassin, "Marginalidad et marginados" in Serge Paugam (org.), L'exclusion: l'état des savoirs, Paris, La Découverte, 1996, p.270. 
na. ${ }^{50}$ Ou melhor, na exata medida em que a "outra nação" americana descartável assumia traços inconfundíveis de terceiromundização com a multiplicação de pequenos métiers subproletários, reaparição das sweat-shops, trabalho a domicílio ou pago por peça, floração de todo um leque de novos ilegalismos e traficâncias, etc. ${ }^{51}$ Seria o caso de dizer que se deu por tabela a brasilianização dessa percepção francesa das formas contemporâneas da miséria social sobre fundo da nova desgraça econômica, na esteira de um outro grande lugar comum: como sugerido, o termo de comparação americano para qualificar a atual escalada das desigualdades, notadamente urbanas e concentradas nos bairros deserdados das grandes cidades. E tal como o similar americano - não custa repisar - a réplica francesa também se assemelharia na mesma relegação tiers-mondisée. Revistas as coisas por esse ângulo, o atual mal-estar francês na civilização também cristalizaria antes de tudo numa nova questão urbana de corte inédito, caracterizado justamente por uma decupagem binária da sociedade: cada vez mais a cidade deixaria de ser o quadro material da sociedade para sediar um tipo de organização espacial que exponencia a dessolidarização social em curso, a secessão americana definidora da ressurgência contemporânea da questão social. ${ }^{52}$ Em suma, à certa altura começou a tornar-se corrente o emprego da expressão "société duale", com pleno conhecimento de causa quanto à origem americana desse barbarismo em

50. Cf. Id., ibid., p.263.

51. Cf. Loïc Wacquant, "De l'Amérique comme utopie à l'envers”, in Pierre Bourdieu (org.), La Misère du Monde, Paris, Seuil, 1993, pp.175-176.

52. Cf. Jacques Donzelot, "La nouvelle question urbaine", Esprit, novembro 1999. franglais, para assinalar a coupure sociale que se tornara o traço dominante, por exemplo, do mundo francês do trabalho, rachado de alto a baixo entre um núcleo integrado de trabalhadores politécnicos e a massa marginalizada dos precários, condenados inclusive a brigar pelo triste privilégio de vender serviços pessoais aos titulares de rendimentos estáveis. ${ }^{53}$ Fundindo os dois registros - a polarização urbana e a bipartição do assalariamento -, dois autores do Québec (quem diria) apelam significativamente para a noção de "banlieu du travail salarié" para situar mais vivamente na imaginação o processo de dualização das sociedades centrais, no caso, outra vez, de um lado o núcleo estável de uma nova elite de assalariados, do outro, uma ampla faixa precarizada de mão-de-obra d'appoint. ${ }^{\mathbf{5 4}}$ A analogia americana apresenta obviamente limites. ${ }^{55}$ Mesmo assim, descontados os clichés alarmistas e estigmatizantes embutidos na síndrome americana ${ }^{56}$, não é

53. Cf. André Gorz, Métamorphoses du Travail, Paris, Galilée, 1991, pp.86,94.

54. Paul Greil e Anne Wery, Héros Obscurs de la Précarité, Paris, L'Harmattan, 1993.

55. P.ex., como os apontados por Loïc Wacquant no artigo citado. No caso do paradigma dual das cidades globais, já nos referimos às reticências de Edmond Préteceille, reiteradas, como se viu, noutro artigo sobre uma Paris que se encaixa mal no modelo de Saskia Sassen, "Inegalités, division sociale e ségrégations: les transformations récentes de la métropole parisienne", in Duhem, Grésillon, Kohler (orgs.), Paris-Berlin, Paris, Anthropos, 2000. Ver ainda, Marie-Christine Jaillet, "Peut-on parlez de sécession urbaine à propos des villes européennes?", que não obstante conclui o artigo por uma análise da muito real tentação da dessolidarização que ronda a próspera Toulouse na corrida para integrar o pelotão das "cidades que ganham”, Esprit, novembro de 1999; no mesmo número, os urbanistas François Ascher e Francis Godard ainda são de opinião que a secessão urbana à maneira de Los Angeles, Caracas ou "telle ville brésilienne", está longe de anunciar o futuro próximo das cidades francesas, cf. "Vers une troisième solidarité".

56. Para uma breve análise de idéias feitas do tipo "os motins urbanos ameaçam a coesão social”, ver, p.ex., Bruno Hérault, "Peurs sur la ville”, in La Pensée Confisquée, obra coletiva do Club Merleau-Ponty, Paris, La Découverte, 1997. 
pequena a pertinência do paralelismo, a começar é claro pela inegável radicalização de certos processos de dualização, ostensivos em certos subúrbios franceses que nada diferem da deriva recente das inner cities americanas. ${ }^{\mathbf{5 7}}$ De qualquer modo, americanização e alguma variante da alegação periférica passaram a andar juntas, para bem e para mal, no mesmo vocabulário de denúncia - à esquerda e à direita - da falha geológica que vai trabalhando a sociedade francesa. Não por acaso a única menção explícita ao Brasil de que tenho notícia comparece, devidamente acompanhada de seu par americano, num estudo de caso de amotinamento suburbano, deixando então para trás de si a sensação de que a via está de fato livre não só para a tiersmondisation dos bairros pobres mas que largas porções do território estão sendo envolvidas passo a passo numa "espiral de subdesenvolvimento": "au pire le Brésil; au mieux l'inner city des villes américaines. Nous voilà bien loin des ambitions européennes"58.

Em julho do ano passado (2000), o boletim de conjuntura do Insee anunciava que a máquina econômica francesa rodava "à plein régime". De fato, a França crescia pelo terceiro ano consecutivo, enquanto a curva do desemprego continuava descendente, passando então de $12,5 \%$ para 9,1\% durante o período. Mas nem por isso o Presidente Jacques Chirac recolheu o seu antigo bordão de campanha

57. Como aliás admite o próprio Wacquant no artigo de há pouco. E mais meia dúzia de anos depois, confirmando numa direção surpreendente a radicalização de tais processos de dualização - que é próprio de um mercado de trabalho cada vez mais "dual", a regulação da precarização social decorrente pela progressiva substituição do Estado Social pelo Estado Penal ampliado. Cf.Loïc Wacquant, Les Prisons de la Misère, Paris, Raisons d'agir, 1999.

58. Christian Bachmann, Nicole Le Guennec, Autopsie d'une émeute, Paris, Albin Michel, 1997, p.212. eleitoral. Contrariando o senso comum econômico (quem haveria de dizer ...), Chirac lembrou mais uma fez que a famigerada fracture sociale - segundo consta "conceito" lançado em 1995 pelo antropólogo Emmanuel Todd e pelo economista Henri Guaino - pelo contrário recrudescera nos últimos dois anos, acrescentando até uma pitada de paradoxo latino-americano: o retorno do crescimento econômico não aumenta automaticamente o poder aquisitivo da população. A chave do mistério é simples: franceses! ainda um esforço para aprofundar as "reformas"!59 Contra-prova? Para variar o furta-cor Alain Touraine que ora confraterniza com o sub-comandante Marcos, ora sacramenta o Brasil privatista de seu ex-colega Cardoso de Paris X - mesmo congratulando-se pelo incremento da autoconfiança dos franceses tampouco deixou de aproveitar a deixa para martelar na velha tecla conservadora das "reformas", como nos bons tempos de Juppé l'audace. ${ }^{60}$ Digamos todavia que um tal lance de retórica eleitoral requentada não deixou de ser comandado por uma espécie de má consciência sociológica. Peripécia involuntária corroborada àquela altura por vários políticos de outros partidos, a saber: que o problema ainda é, ontem como hoje, o da exclusão "dura", a dos que continuarão de fora, uma vez que as empresas recrutarão apenas os mais “empregá-

59. Bem entendido "reformas" numa acepção inédita do termo. Como ficou claro na greve da função pública francesa de dezembro de 1995, e já era uma evidência escarninha no Brasil desde $1^{\circ}$ de janeiro do mesmo ano, "o conceito de reforma social deixou de ser progressista e foi adotado pelos conservadores; deixou de significar incremento social e passou a indicar o regresso ao capitalismo brutalizado de Manchester no século XIX. Após transformar o conceito de reforma social em seu contrário e preenchê-lo com conteúdos antisociais, o governo [francês] passou a criticar os sindicatos com um cinismo inaudito, taxando-os de 'incapazes para a reforma' “, Robert Kurz, Os últimos combates, Petrópolis, Vozes, 1997, p.282.

60. Entrevista à Folha de São Paulo, 09/07/2000. 
veis", sem falar no fato de que a retomada pode endurecer ainda mais a sociedade etc. ${ }^{61}$ Dito e feito: por aquela mesma época os conflitos trabalhistas voltavam a se radicalizar de uma maneira inesperada: além das ocupações, ameaças de converter as usinas paralisadas em bombas relógio ecológicas, quando não de simplesmente mandar tudo pelos ares. É verdade que na maioria desses casos se trata de setores condenados, mas, na hora da retomada do crescimento, esses assalariados jubilados parecem não mostrar mais a menor disposição, como dizem os próprios interessados, "d'être les laissés-pour-compte de la reprise", além do mais embrulhados por um enésimo plano social de "refundação" de qualquer coisa. É nesse ponto como veremos logo mais - que o Brasil redualizado de hoje faz a diferença, e a brasilianização do mundo começa a mudar de sinal, credor de um legado histórico de fazer inveja aos dirigentes europeus mais ou menos constrangidos por algumas gerações de Contrato Social: assim, num país de dualização originária, o próprio Presidente da República pode anunciar impunemente que muitos milhões de seus compatriotas de baixa ou nula empregabilidade serão devidamente rifados pela reingenharia social em curso, sendo além do mais saudado pelo distinto público pela audácia da isenção sociológica com que lida com os fatos da vida nacional.

Um ou dois dualismos? Afinal é disso mesmo que se tratará mais à frente. Ou desde já, na visão mais convencional dos franceses alarmados, porém fazendo as devidas distinções: nas palavras de Claude Julien, “o mesmo sistema desenvolve, ao Norte, um dualismo que se quer ‘civilizado' e, no Sul, um dualismo cujo caráter selvagem

61. Le Monde, 01/08/2000. ninguém mais tenta dissimular"62. Sendo a globalização seletiva - e isso quase por definição, a despeito do mito da convergência das pretéritas economias nacionais devidamente mundializadas - , produz desconexões drásticas tanto na base como no topo da hierarquia mundial: em princípio a "fratura" no Centro e na Periferia não evoluiriam no mesmo diapasão. Ocorre que a tal brasilianização do mundo, como estão nos dizendo e nos interessa testar, indica justamente a contaminação da polarização civilizada em andamento no núcleo orgânico do sistema pelo comportamento selvagem dos novos bárbaros das suas periferias internas, que se alastram propagando a incivilidade dos subdesenvolvidos, de sorte que a grande fratura passa a ser vista também como a que separa os que são capazes e os que não são capazes de policiar suas próprias pulsões, como transparece, por exemplo, na retórica securitária do Manifesto "Républicains, n’ayons plus peur!", divulgado em setembro de 1998 por Régis Debray e seus companheiros da esquerda musclée. Não tenhamos mais medo, no caso, de compensar o encolhimento econômico e social do Estado pela sua expansão em matéria policial e penal: ao seu modo, a tal fratura social também exige "tolerância zero", nenhuma vidraça quebrada etc. ${ }^{63}$ De sintoma confusamente diagnosticado, a fraseologia da fratura (social, urbana ou o que for) pode num relance bascular e engordar o arsenal ameaçador dos riscos a pedirem provi-

62. "Ces élites qui régnent sur des masses de chômeurs", Le Monde Diplomatique, abril de 1993, p.9.

63. Veja-se o comentário dessa lamentável derrapagem em Loïc Wacquant, Les Prisons de la Misère, ed.cit., pp.125-131. Pelo sim pelo não, observo que o Autor, justamente alarmado diante da expansão galopante desse novo senso comum punitivo, nem por isso deixa de lembrar que não se deve caluniar in abstracto a polícia e seus congêneres. 
dências gestionárias que nem sempre se distingue de um estado de sítio que vai madrugando com a ordem imperial que se avizinha.

Dito isso, é sempre bom recordar — retomando o nosso fio - que o famigerado discurso da fratura social, dividindo as populações afetadas em dois pacotes, foi propagado com enorme sucesso por Jacques Chirac durante a campanha presidencial. Sua alma sua palma: uma boa cartografia das fraturas francesas - como a estabelecida recentemente por um geógrafo independente ${ }^{64}$ - confirma com efeito, para além, muito além da visão caricata dos subúrbios difíceis, devorados pela anomia, o advento de uma sociedade antagônica cujas linhas de ruptura vão se alastrando no ritmo mesmo da metropolização e do correspondente estilhaçamento do território e das economias nele ancoradas, lógicas de separação social, cultural e territorial, que vão apagando a imagem republicana tradicional da nação integradora, que vão enfim naturalizando o princípio regulador da desigualdade, desta vez sans phrase. Com efeito. Centrada na retórica altamente duvidosa - para dizer o menos — da exclusão, que por seu turno vinha alimentando há pelo menos uma década uma nova literatura sobre o retorno da Questão Social com o fim da Era do Crescimento, o discurso da fratura social apresentava de saída a inestimável vantagem de dissolver no grande dilaceramento do mundo o risco desagradável de entrever na imagem do país repartido entre incluídos e excluídos a expressão muito evidente de uma política de produção sistemática de desigualdades, de outro modo intoleráveis e degradantes. Nada mais razoável e até mesmo

64. Christophe Guilluy, Atlas des fractures françaises, Paris, L'Harmattan, 2000. realista, portanto, do que concentrar o foco da fratura como o nome aliás sugere - unicamente na ... exclusão. ${ }^{65}$ Mas tampouco é suficiente descortinar o amplo panorama contemporâneo das desigualdades, sobretudo quando se alega a novidade delas, como ocorre no campo do reformismo modernista. O que significa dizer afinal que estamos ingressando numa nova era de desigualdades? $\mathrm{Na}$ melhor tradição apologética, que a sociedade tem sempre razão, ainda mais num momento dito de "reafirmação democrática" (sic) como o atual, quando está ficando cada vez mais difícil estabelecer a fronteira entre as novas desigualdades e a mudança social propriamente dita, e seus efeitos desestabilizadores sobre indivíduos afetados por uma gigantesca redistribuição de cartas ... ${ }^{66}$ Trata-se no fundo de uma mutação antropológica, na origem de um inédito individualismo de massa, e o que mais a nova língua sociológico-gerencial puder recodificar. Como a idéia edificante de "inserção" - caso fosse possível a alguém permanecer "fora" da sociedade, pois nem mesmo os mortos conseguem. Pela enésima vez: o desempregado não foi "excluído" do mercado, simplesmente não encontra mais quem lhe compre a força de trabalho, assim como o pobre é um consumidor como outro qualquer, só que insolvável - numa palavra, o mercado é uma formação social que não admite nenhum "exterior". ${ }^{67}$ Só para conferir: não

65. O resultado do segundo turno que elegeu Chirac confirmou a justeza dessa estratégia, conclui o mesmo Claude Julien, em cujo comentário estou me apoiando. Cf. "Briève radiographie d'une fracture sociale", Le Monde Diplomatique, junho de 1995.

66. Cf. Jean-Paul Fitoussi e Pierre Rosanvallon, Le Nouvel âge des inegalités, Paris, Seuil, 1996.

67. Cf. Etienne Balibar, Les frontières de la démocratie, Paris, La Découverte, 1991, p.202. 
por acaso as políticas ditas na França “de inserção" têm a mesma idade ideológica dos primeiros tempos de consagração da iniciativa empresarial enquanto fonte perene de inovação e riqueza. Convenhamos que não deixa de ter sua graça a aclimatação francesa da cultura americana de negócios justamente ao longo do período Mitterrand, um certo economicismo de esquerda glamouroso, resservido com um desconto especial ao público brasileiro desde julho de 1994.

Mas voltemos ao caráter afirmativo dessa constelação binária exclusão/inserção. E à bem conhecida aversão de Robert Castel à noção de exclusão. A seu ver importa muito mais destacar o papel estratégico das zonas intermediárias de vulnerabilidade que precedem o décrochage, e mais acima ainda, o epicentro das ondas de choque responsáveis pela mise sur les marges de uma parte crescente da população, pois ao contrário do que imagina o senso comum globalista, não há uma falha absoluta separando as "classes confor táveis" das subclasses dos indivíduos redundantes e banalizados, porém são justamente os in que geram os out: nunca o Centro foi tão onipresente no conjunto da sociedade. Novamente, ninguém está "fora"68. Tudo se passa em suma como se um processo de dualização real engendrasse uma falsa representação de uma ordem social dual consolidada: assim, num registro, percepção dramática de uma sociedade cada vez mais éclatée; noutro, a visão dual-funcionalista de uma economia

68. Cf. Robert Castel, Les Métamorphoses de la Question Sociale: une cronique du salariat, Paris, Fayard, 1995; trad.bras., Vozes, Petrópoles, 1998. Ver ainda entrevista do Autor concedida a François Ewald, Magazine Littéraire, $\mathrm{n}^{\circ} 334,1995$. Relembro que também para Castel o paradigma de uma sociedade dual é sem dúvida americano, com a ressalva de praxe segundo a qual a França ainda não chegou lá. avançando em marcha forçada bem à frente de uma sociedade qui a du mal à suivre, como se diz nos documentos oficiais, sendo que os modernizadores de plantão estão aí para isso mesmo.

Não há brasileiro que não tenha visto esse filme, e para cuja edificação não será desinteressante relembrar os termos familiares nos quais Alain Touraine - para variar - recodificou a nova apologética da fratura social. Mais uma vez: a ruptura de época que estaríamos em princípio vivendo nada mais seria do que o rito de passagem de uma sociedade vertical de exploração econômica para uma sociedade individual de exclusão, na qual o decisivo não é mais pertencer ou não aos estratos superiores ou inferiores porém estar no centro ou na margem, de sorte que quem está fora viveria numa espécie de vazio social forçando a entrada no mundo dos integrados. ${ }^{69} \mathrm{O}$ que resta de antagonismo numa sociedade de atores individuais a um tempo fraturada, e por assim dizer, interacionista, é uma luta por reconhecimento, nem que seja por meio do confronto direto proporcionado por um motim, e não obviamente por transformação; numa palaura, integração ao invés de emancipação. Será preciso acrescentar? Nesse quadro de fracionamento horizontal, o núcleo dos incluídos representa o pacote "moderno" da sociedade que além do mais - aqui a boa notícia - funciona muito bem obrigado e de costas para a massa sobrante dos inadaptados, sem precisar explorá-los, nem mesmo coagi-los. Nessa indiferença, infelizmente, a principal fonte da violência e incivilidades. Posso estar enganado, mas creio que o gol-

69. Cf.. Alain Touraine, "Face à l'exclusion", in Citoyennité et Urbanité, Editions Esprit, 1991, apud Joël Roman, La Démocratie des Individus, Paris, Calmann-Lévy, 1998, pp.19-20. Mais recentemente, entre outros escritos do mesmo Touraine, Pourrons-nous vivre ensemble?, Paris, Fayard, 1997. 
pe de misericórdia nessa periodização celebratória - era uma vez uma sociedade de classes baseada na exploração econômica, à qual sucedeu um sociedade de indivíduos movida pelo entra e sai meritocrático nas redes de afluência - foi dada afinal, pelo menos no âmbito do correspondente debate francês, por Luc Boltanski e Ève Chiapello, ao reintroduzirem nos seus próprios termos, quer dizer na linguagem mesmo da sociedade em rede, para a qual só a exclusão faz sentido e justamente como “desconexão", a noção crítica de exploração para além do vínculo clássico do assalariamento. Para tanto, trataram de levar a sério a noção afirmativa de exclusão, a ponto de convertê-la no seu contrário, a saber, uma forma de exploração que se desenvolve num mundo conexionista, mas agora um mundo em que a realização do lucro passa pela mise en reseaux das atividades. ${ }^{70}$ Dito isso assim de passagem pois interessa ressaltar desde agora -- e do ponto de vista da Periferia, uma vez que está na berlinda uma certa fratura brasileira do mundo, apresentado por sua vez como uma Rede de redes e localizações - , entre tantas categorizações novas, a existência bem tangível de mecanismos de extração de mais-valia "em rede"71, como, por exemplo, relações econômicas fundadas em "diferenciais de mobilidade", aliás a cifra mesmo da estratificação da economia mundial, para ir direto ao ponto, sobre o qual por certo voltaremos.

Como disse, essa dualidade unidimensional é bem conhecida ao sul do Equador, onde foi aplicada como um

70. Cf. Luc Boltanski e Ève Chiapello, Le Nouvel Esprit du Capitalisme, Paris, Gallimard, 1999.

71. As "rendas informacionais" de que fala por exemplo Marcos Dantas nos trabalhos mencionados. Entre outros "valores" reapropriados pelo atual sistema de enclosures da riqueza "imaterial" gerada socialmente. compasso a uma outra fratura (agora sem aspas) mais originária, a rigor "colonial", compasso destinado a medir o que nos faltava e nos mantinha à distância da modernidade, na qual devíamos nos integrar, já que patinávamos no desvio, numa espécie de limbo civilizacional, como os "excluídos" de hoje. Não é que não fosse esse o caso. Ontem como hoje, o problema é que quem pede para entrar normalmente não critica nem olha preço, para variar pago por uma nova categoria de "excluídos" da modernização, recomeçando o ciclo do subdesenvolvimento, para falar com um pouco de mais precisão, além de nos devolver ao nosso ângulo de ataque, o ponto de vista das periferias reenquadradas pelas novas disciplinas do capital vitorioso.

Comentando o sucesso crescente da noção passe-partourt de exclusão - consensualmente empregada à esquerda e à direita - Serge Paugam relembra - e não custa repisar - que o debate francês nos anos 70 girava basicamente em torno das relações de dominação e sua reprodução, cuidando muito excepcionalmente dos marginalizados pela modernização ou esquecidos pelo progresso. ${ }^{72}$ Não que elas tenham desaparecido, deram inclusive um enorme passo adiante, multiplicando processos inéditos e dramáticos de ruptura. Para além do conflito clássico de interesses entre grupos sociais antagônicos - e que por isso mesmo se reconhecem como tais - a atual explosão de desigualdades, em uma sociedade até então razoavelmente integrada, seria na verdade a expressão de um colapso do próprio vínculo social — outra expressão consagrada para representar a coesão social ameaçada pela generalização das ditas fraturas, cujo grau de comprometimento estaria assumindo proporções

72. Cf. obra coletiva citada, L'exclusion: l'état des savoirs. 
brasileiras irreversíveis, a acompanhar o atual repertório francês da precarização. Acresce que a exclusão assim entendida já não carrega consigo nenhum princípio de recomposição da sociedade - como nos bons tempos da luta de classes e seu horizonte de superações definitivas. Daí a escalada exponencial da violência, para citar outro tema dileto do atual reformismo conservador e ao qual com certeza voltaremos, pois força bruta é conosco mesmo, sem falar em nosso espantoso acervo de incivilidades. E o respectivo diagnóstico de ajusta: a violência seria uma das variantes da doença senil de uma sociedade industrial em declínio e de instituições republicanas em estado falimentar ${ }^{73}$. Novamente, disfunção patogênica por motivo de mudança social acelerada, menos uma crise do que a inauguração turbulenta de um outro paradigma civilizacional, acompanhada de falência múltipla dos enquadramentos formadores das antigas solidariedades, família, escola, empresa, sindicato, etc. Nessas circunstâncias, seria mesmo de se esperar uma reformulação "violenta" dos modos de se "fazer sociedade" - enfim, uma tese funcionalista clássica reciclada agora numa outra ambiência de "gestão" do social enquanto fratura exposta.

Uma ambiência de reengenharia de riscos e inseguranças que se poderia chamar então de pós-nacional, se é verdade que Nação e Questão Social sempre andaram juntas, datando a "invenção do social"74 de um arranjo

73. Cf. Michel Wieviorka, Violence en France, Paris, Seuil, 1999.

74. Título de um livro de Jacques Donzelot, Paris, Fayard, 1984. Para um comentário da periodização proposta pelo Autor - o Estado Social, destinado a contornar o conflito secular entre patrimônio e trabalho, de sorte que a segurança e o direito não dependessem mais exclusivamente da propriedade, teria começado a nascer depois do traumatismo de 1848 - , ver Robert Castel, op.cit., pp.269-275. original de regulações e proteções desmercadorizadas, e a invenção política da nação consistindo na formação de uma sociedade institucionalmente capacitada para existir como um conjunto ligado por relações de interdependência. ${ }^{75}$ Mas se é assim, a implosão do Estado Social e a consequente invalidação do vínculo social que ele descontratualizara - nem tudo é contratual num contrato, a começar pela compra e venda da força de trabalho - deixa ver retrospectivamente que de fato só há sociedade de "semelhantes", como queria Durkheim", e que uma sociedade de semelhantes só pode ser nacional, na acepção republicana que se está dando ao termo, de outro modo a mbíguo até à raiz do cabelo. A fratura que dualiza é justamente essa dissolução de uma sociedade de "semblables", a rigor a negação da idéia mesmo de sociedade, que já não parece mais fazer sentido algum ${ }^{77}$, como tampouco uma

75. Cf.Robert Castel, op.cit., pp.18,19.

76. Ainda Castel (ibid., pp.277-278): que realça a afinidade da concepção "sociológica" de sociedade em Drukheim, adversário do postulado de base da antropologia liberal, obviamente individualista e economicista, quer dizer, o reconhecimento de grandes regulações objetivas dos fenômenos sociais, com a dos "republicains de progrès", na origem Estado Social francês. Um amplo arco de coerência se estenderia assim do nascimento conjunto da Sociologia moderna e da Questão Social no século XIX - em princípio, tal questão, solucionável por uma espécie de reforma social permanente, induzida por algo como um arranjo político tácito entre liberais e socialistas depois de 1848, se Wallerstein tem razão — até à regulação de tipo keynesiano das sociedades salariais nacionais, precarizadas pela atual revanche dos mercados. Compreende-se então que a sociologia decline até à extinção a partir do momento em que - por motivo de globalização ou coisa que o valha - a idéia "nacional" de reforma social seja declarada obsoleta, salvo é claro na sua atual acepção antisocial invertida. Sobre esse eclipse concomitante de uma disciplina que nasceu conservadora e não obstante está condenada por vício de progressismo, e de uma resposta coletiva à Questão Social, ver Peter Beilharz, Postmodern socialism - romanticism, city and state, Melbourne UP, 1994, e ainda do mesmo autor, "Globalização, Bem Estar e Cidadania”, in Maria Célia Paoli e Francisco de Oliveira (orgs.) Os sentidos da democracia, Petrópolis, Vozes, 1999, pp.202-203.

77. Seria ainda o caso de lembrar a provocação famosa? "There is no such a 
sociedade global sucedânea, uma contradição nos termos para o pensamento social clássico, ainda que essa ressalva não seja propriamente um argumento. A esse fim de linha aludem Castel e Paugam - entre tantos outros - quando relembram que exclusão e sociedade não podem coexistir, a menos é claro que se fabrique um outro conceito para o atual espaço de não-relações sociais que se está cristalizando com a desafiliação em massa da ordem salarial específica do ciclo histórico recém-findo. Voltando às novas violências urbanas, que os atuais ideólogos e gestores globalitários encaram como o preço a pagar na transição de uma sociedade regida por um conflito central para uma outra "coisa" caracterizada pelo individualismo de massa (como Marcel Gauchet denominou a "sociedade da inseguridade"), faz então todo sentido anunciar que a França hoje é palco de uma desestruturação espetacular, nada mais nada menos que a revogação da sociedade nacional francesa ${ }^{78}$ - o que os americanos começam a chamar de brasilianização, com a diferença é claro que num chegamos a conhecer uma sociedade salarial de verdade.

Estamos portanto de volta ao nosso cenário de origem: a síndrome brasileira da construção nacional abortada, e além do mais interrompida numa sociedade drasticamente heterogênea, "dualizada” pelo próprio processo de modernização, o que precisamente define o subdsenvol-

thing as society" (Margareth Tatcher), a "exclusão" que o diga. Assim como as abstrações podem destruir a realidade, o nominalismo também aniquila o seu próprio princípio de individuação.

78. Cf. Michel Wievieorka, op.cit., p.47. Fechando o ciclo, com a palavra o inventor da "fratura social": "la nation, qui enferme les riches et les pauvres dans un réseau de solidarités, est pour les privilégiés une gêne de tous les instants", Emmanuel Todd, L'Illusion Économique, Paris, Gallimard, 1998, p.153. vimento como resultado histórico e não etapa a ser percorrida linearmente. (Em tempo: como não dispomos de moeda conversível nem comandamos nenhum processo endógeno de inovação tecnológica, uma outra provocação famosa continua a ser o que sempre foi, apenas uma provocação: o Brasil não é um país subdesenvolvido - apenas injusto, como reza o seu complemento cínico). De volta ao nosso ponto de partida, porém com uma ressalva: na hipótese, hoje sujeita à revisão ${ }^{79}$, de que uma construção nacional de tal ordem estava efetivamente em curso desde que em meados do século XIX o Estado brasileiro, com a proibição do tráfico negreiro, emergiu da clandestinidade, na tese bem conhecida do historiador Luiz Felipe de Alencastro sobre as origens da nacionalidade. (A desfaçatez do disparate entre parênteses não deixa de reforçar a hipótese de que a ansiedade de elite com algo como um déficit de construção nacional a ser saldado pode muito bem não ser mais do que um outro mito restropectivo em nossas grandes narrativas fundacionais. Veremos). Ora, se antes já era justamente essa famigerada "dualidade" que nos fazia pensar (no seu devido tempo, procurarei explicar como e porque) - a saber, a coexistência e determinação recíproca do Centro e da Periferia no mesmo espaço social, mola secreta da "dupla fidelidade" que agoniava nossos varões sabedores -, muito mais agora, em princípio pelo menos, que nossa fratura colonial congênita foi enfim igualada pela de um mundo que obviamente ja-

79. Por exemplo, no ensaio exploratório de José Luis Fiori, “A propósito de uma 'construção nacional interrompida" ", in José Luis Fiori, Brasil no espaço, (Petrópolis, Vozes, 2001), precedido por uma outra inscursão pioneira de Maria da Conceição Tavares "Império, Território e Dinheiro", in J.L.Fiori (org.), Estados e Moedas no desenvolvimento das nações, Petrópolis, Vozes, 1999. Está claro que voltaremos ao assunto. 
mais conheceu a condição colonial (salvo os Estados Unidos e num outro registro, muito embora tenha sido uma República escravista), mas agora tão polarizado quanto uma imensa periferia, periferia que por seu turno sempre apostara no processo inverso, imantada pela redenção da homogeneidade social à européia que agora se esfarela seja isso dito e redito para resumir o argumento.

Será preciso ainda acrescentar (nunca se sabe) que brasilianização global não quer dizer que o futuro do mundo seja o "atraso" ou alguma variante tropical de capitalismo selvagem - sobretudo quando se tem em mente a corrupção endêmica nos países centrais, já aclimatada como uma segunda natureza da economia desregulada e autonomizada - ao contrário, matriz colonial aqui é sinônimo de vanguarda num sentido muito preciso: "enquanto outras colônias se estruturavam como colônia de povoamento, portanto na retaguarda da expansão mercantil (...), o Brasil exemplarmente, nascia para o sistema na vanguarda, isto é, como lugar de produção"80. Hoje voltamos à vanguarda, só que da desintegração. ${ }^{81} \mathrm{Na}$ de ontem, quando éramos fronteira avançada do désenclavement planetário da economia-mundo capitalista ${ }^{82}$, ocupávamos o

80. Francisco de Oliveira, "A vanguarda do atraso e o atraso da vanguarda", in Os direitos do antivalor, Petrópolis, Vozes, 1998, p. 206.

81. Na fórmula de Roberto Schwarz, sob o impacto do fim de linha anunciado por Robert Kurz, aliás, justamente descoberto e lido nos idos de Collor, "Ainda sobre o livro de Kurz", Novos Estudos, CEBRAP, n 37, 1993.

82. Recorrendo livremente a uma expressão de Jacques Adda, La mondialisation de l'économie, Paris, La Découverte, 1996. Com segundas intenções,éclaro,quandomaisnãosejaporpropiciaroseguinteesclarecimento, já não sem tempo. O conceito de economia-mundo, que remonta a Braudel e foi explorado pelos teóricos da World-System Theory, destaca - à contracorrente das concepções liberais e marxistas convencionais, que pressupunham um espaço econômico politicamente neutro - o caráter político a um tempo plural e hierarquizado (como dizia o mesmo Braudel, não há capitalismo sem extremo quimicamente puro de uma configuração social propriamente monstruosa, na qual se exprimiria o sentido mesmo da colonização, e como estamos vendo, um passado de muito futuro. Refiro-me à prevalência (e transparência) absoluta da razão econômica na gênese de uma "sociedade" que por isso mesmo (se Mauss e Durkheim têm alguma razão ...) dificilmente poderia atender por esse nome. No resumo exemplar de Celso Furtado: "Os que chegam trazem consigo meios neces-

hierarquia e todo o tipo de assimetrias sociais que redundam em monopólios) do sistema mundial das trocas capitalistas. Assim, o espaço econômico internacional que se constitui na esteira do grande désenclavement europeu é desde o início um espaço, como se disse, fortemente hieraquizado, cuja expansão é indissolúvel da concorrência que contrapõe os Estados ocidentais e que se exprime na luta pelo controle das zonas periféricas. Quando se diz que no espaço de meio milênio essa economia-mundo se tornou planetária, isso não quer dizer que ela não tenha sido "global" desde o big bang que a engedrou. (Compreendamos enfim o disparate de um capitalismo originário brotando em um só país, como a Inglaterra da Revolução Industrial, e daí irradiandose pelo mundo numa corrida de obstáculos entre o pelotão dos "adiantados" e a rabeira dos late-comers; despropósito simétrico ao juízo apologético de hoje a respeito do capitalismo que deu certo nos países "avançados", do tipo: pelo menos lá onde ele funciona, funciona muito bem). Mais exatamente, tratando-se de uma rede de trocas implicando uma divisão do trabalho se espraiando por um espaço plurinacional - seja dito para simplificar, pois uma tal multiplicidade de jurisdições políticas recortando os territórios econômicos não precisa necessariamente assumir a forma "nacional", uma forma histórica entre outras —, e cuja compulsão de nascença à acumulação ilimitada proibe-lhe tanto encerrar-se num espaço político singular, quanto obriga a exponenciar a competição entre os poderes políticos rivais, barrando assim a hipótese - tentação recorrente - de um espaço estatal único de cunho imperial. Portanto, tratando-se de um sistema de fluxos de fatores transfronteiras e localizações econômico-políticos, estamos falando de um sistema que nesse desenclavement original (de cujo flanco brotamos) nasceu de uma só vez "global" e "nacional". Isso dito para já ir desarmando a falsa querela entre globalistas e localistas das mais variadas procedências e obstinações doutrinárias. E mais - ou sobretudo, pois aqui reside a matriz básica das polarizações que está nos interessando repertoriar - é precisamente na fronteira de contiguidade entre Centro e Periferia, e que os referidos teóricos denominam de semiperiferia, que nos situamos, ideológica e materialmente, e isso desde que tal espaço intermediário se configurou ao longo do século XIX, na condição de variável de ajuste do centro cíclico de turno. Aqui, como sugerido e ainda veremos mais de perto, a matriz sistêmica de nossa Dualidade de nascença, tanto a real quanto o seu símile ideológico. 
sários para por em marcha uma empresa que já nasce próspera (...) Um povo de comerciantes criava a primeira organização produtiva agrícola do Hemisfério Ocidental, vinculada ao mercado europeu (...) Estava lançada uma operação transcontinental de grande envergadura, com o objetivo de criar um fluxo de exportação para um mercado situado a milhares de quilômetros. Dessa forma, os critérios econômicos se sobrepõem a tudo. Poucas vezes na história humana uma formação social terá sido condicionada em sua gênese de forma tão cabal por fatores econômicos". ${ }^{33}$ (Marx não dizia coisa muito diferente quando apresentava a empresa colonial como a câmara de decantação da verdade oculta na metrópole.) Resumo no qual ainda ecoam as considerações finais de Caio Prado Junior sobre a conformação colonial do Brasil contemporâneo, confrontando a eficiência de nossa ordem colonial enquanto organização produtiva com sua esterilidade "no que diz respeito a relações sociais de nível superior". A seu ver, dado o exclusivo da exploração econômica bruta, o que define o viver na periferia de matriz colonial moderna é essa "falta de nexo moral", tomado no seu sentido amplo de "conjunto de forças de aglutinação, complexo de gerações humanas que mantêm ligados e unidos os indivíduos de uma sociedade e os fundem num todo coeso e compacto". ${ }^{84} \mathrm{E}$ então? Onde se diz nexo moral ausente numa quase-sociedade de vanguarda mercantil, podemos ler erosão e invalidação do tal lien social cuja evaporação contemporânea tira o sono dos franceses ameaçados de brasi-

83. Celso Furtado, A Fantasia Desfeita, São Paulo, Paz e Terra, 1989, p.15.

84. Caio Prado Junior, Formação do Brasil Contemporâneo, São Paulo, Brasiliense, $15^{\mathrm{a}}$ Edição, 1977, pp.344-345. lianização. ${ }^{85}$ Acontece que brasilianização, como o Ser em Aristóteles, se diz em mais de um sentido.

\section{O mundo sem culpa (I)}

Quando o mau juízo de Michael Lind acerca do caráter brasileiro da sociedade americana em gestação foi divulgado entre nós, deu obviamente algum pano para manga. Convidado pela imprensa a "repercutir" o prognóstico sombrio, o antropólogo Roberto da Matta reagiu à altura, quer dizer, à altura de uma ilustre linhagem explicativa das singularidades do país: "o uso da expressão brasilianização para exprimir um estado de injustiça social me deixa ferido e preocupado. De um lado, nada tenho a dizer, pois a caracterização é correta. De outro, tenho a dizer que o modelo de Michael Lind exclui várias coisas. A hierarquia e a tipificação da estrutura social do Brasil indicam um modo de integração social que tem seus pontos positivos. Nestes sistemas, conjugamos os opostos e aceitamos os paradoxos da vida com mais tranqüilidade. Seria este modo de relacionamento incompatível com uma sociedade viável em termos de justiça social? Acho que não. Pelo contrário, penso que talvez haja mais espaço

85. Dos argentinos também, afinal na América Latina nada mais próximo da Europa do que Buenos Aires. Como disse, não tinha conhecimento do emprego direto do neologismo brésilianisation na literatura francesa sobre a atual explosão das desigualdades. Todavia leio num artigo de Marie-France Prévôt Shapira sobre a fragmentação das cidades latino-americanas, que num doutorado de 1998 na EHESS sobre o processo de pauperização da classe média argentina, o autor considera que a Argentina vai afinal se aproximando do tipo mesmo da sociedade dual, a saber, o Brasil, e mais precisamente, que numa cidade dopada pela chegada dos investimentos estrangeiros como Buenos Aires, "la peur de la brésilianisation alimente un discours sécuritaire et des logiques de démarquage", Esprit, novembro 1999, p.133. 
para que estes sistemas híbridos e brasilianizados sejam autenticamente mais democráticos que estas estruturas rigidamente definidas, nas quais tudo se faz com base no sim ou no não. Afinal, entre o pobre negro que mora na periferia e o branco rico que mora na cobertura, há muito conflito, mas há também o carnaval, a comida, a música popular, o futebol e a família. Quero crer que o futuro será mais dessas sociedades relacionais do que dos sistemas fundados no conflito em linhas étnicas, culturais e sociais rígidas. De qualquer modo, é interessante enfatizar a presença de um estilo brasileiro de vida como um modelo para os Estados Unidos. É sinal de que tem mesmo água passando embaixo da ponte."86

Bem lembrado, com efeito. No caso, a lendária maleabilidade desse modo de ser com livre trânsito entre as classes, e de cunho simpaticamente popular. É claro que com um enorme, porém, como logo se verá. Para abreviar e dar uma referência clássica, podemos dizer sem erro que esse quadro estilizado descende em linha direta do Brasil de antagonismos em equilíbrio, a rigor inventado por Gilberto Freyre, não obstante o forte apoio na enganadora persistência da ordem patriarcal. Volto a lembrar que Mário de Andrade costumava dizer que éramos uma "imundície de contrastes", mas isso em seu último período de empenho ilustrado no adiantamento mental e institucional do país. Enquanto o vanguardista retroverso Gilberto Freyre via nisto antes de tudo um luxo, mais exatamente, "um luxo de antagonismos". Podemos imaginar com que prazer teria relacionado o lapso bem paulista da "imundície" com as profiláticas luvas de borracha como certa vez caracterizou a colonização inglesa na Índia, por

86. Roberto Da Matta, Folha de São Paulo, 09.07.95, p.I-26. oposição ao amálgama tenso, porém harmonioso criado nos trópicos por um colonizador indefinido, meio europeu meio africano, como via o português. Lembro esta momentânea inversão de posições apenas para salien$\operatorname{tar}^{87}$ o quanto sua visão, a um tempo dessublimadora e gostosamente complacente, permitiu-lhe apresentar uma imagem em ruptura com a obsessão complexada de ajustar o país à marcha da civilização. Dito isto, não podemos passar adiante sem relembrar, restabelecendo a verdade histórica, que tal desrecalque anti-burguês deveu-se é claro à revelação modernista de que a modernidade pode ser plural, que nada nos obrigava a alinhar com a bisonha modernolatria dos futuristas europeus, por exemplo. Em suma, na réplica do autor de Carnaval, malandros e heróis repercutia ainda o contraponto nostálgico de Gilberto Freyre, obviamente a nosso favor, entre, de um lado, as "duras linhas puritanas" do colonizador inglês, e do outro, "o tipo contemporizador, sem ideais absolutos, nem preconceitos inflexíveis", que teria sido plasmado na América Portuguesa.

Esse cotejo desfavorável à rigidez da norma puritana, na origem da formação histórica dos Estados Unidos, em benefício do termo de comparação brasileiro, por motivo de simpática aversão ao universo das disciplinas modernas, a ponto da eventual generalização de um certo estilo brasileiro de vida ser saudado como uma boa notícia para a causa da civilização, tem um outro precedente mais do que ilustre. Estou me referindo ao estudo fundamental de Antonio Candido sobre as Memórias de um sargento de

87. Na esteira de Ricardo Benzaquen de Araújo, Guerra e Paz - Casa Grande e Senzala e a obra de Gilberto Freyre nos anos 30, Rio de Janeiro, 34 Letras, 1994. 
Milícias, de Manuel Antonio de Almeida, romance de costumes de meados do século XIX no qual se acreditou ver um precursor picaresco de anti-heróis modernistas como Macunaíma e Serafim Ponte Grande. ${ }^{88}$ Até que Antonio Candido mudasse o rumo desta fortuna crítica, reorientando em conseqüência a sondagem literária na direção de uma certa lógica social brasileira até então inexplorada, e no modo comparatista que está nos interessando agora reavivar. Revelou assim um modo de ser muito peculiar de suspensão dos conflitos e dos respectivos juízos morais, responsável por uma sorte de circulação contínua da gente pequena numa sociedade escravocrata, comprimida entre o trabalho servil e as classes proprietárias, entre as esferas da ordem e da desordem, do lícito e do ilícito, e empurrados de cá para lá pela inércia variada dos parasitismos e demais expedientes de sobrevivência, sem maiores dramas de consciência ou empenhos de convicção. O mais surpreendente é que esta arraia miúda, beirando a anomia, desse o tom ideológico para o conjunto da sociedade: seria o caso de lembrar que também os detentores do mando social "conjugavam os opostos", "aceitavam com tranqüilidade os paradoxos da vida”, achando igualmente que as coisas não se fazem "na base do sim ou não"para voltar aos termos em que no trecho referido Roberto da Matta por sua vez repudiaria a duvidosa supremacia do espírito americano do capitalismo sobre a maleável sociedade relacional brasileira. Antonio Candido também era da mesma opinião acerca do déficit de humanidade de uma organização social comandada pela introjeção da Lei

88. O clássico Dialética da Malandragem é de 1970, apenas recolhido em livro em 1993, em Antonio Candido, O Discurso e a Cidade, São Paulo, Duas Cidades. e correspondente extroversão da violência interiorizada sobre os não-eleitos, e da respectiva vantagem civilizatória de uma sociedade que ganha em "flexibilidade o que perde em inteireza e coerência”. Em resumo, a lábil alternância entre a norma frouxa e sua infração sem remorso, que amaina as tensões e dá lugar a toda sorte de acomodações, "nos fazem parecer por vezes inferiores ante uma visão estupidamente nutrida de valores puritanos, como a das sociedades capitalistas", mas com certeza haverá de facilitar "nossa inserção num mundo eventualmente aberto". ${ }^{89}$ Esse mundo aberto, no qual se destacaria a contribuição milionária de nossas idiossincrasias, obviamente não veio. E se acaso chegasse, encontraria a dialética brasileira da malandragem de ponta cabeça. Deu-se o contrário em todas as frentes, como sabemos. Mas deu-se sobretudo um outro enorme disparate, a inversão positivadora da tese da brasilianização do Ocidente. Da parte de um europeu, nada mais genuinamente brasileiro.

\section{O admirável mundo novo do trabalho é aqui}

Até onde posso saber, o mais recente europeu a lançar o mote da brasilianização das sociedades centrais foi o sociólogo alemão Ulrich Beck, autor do slogan Sociedade de Risco e propagador da idéia de Modernidade Reflexiva ou Segunda Modernidade, de Anthony Giddens. ${ }^{\mathbf{9 0}}$ Como seus precursores americanos, principiou empregando o neologismo na sua acepção entrópica mais evidente,

89. Op.cit., p. 53.

90. Cf. Ulrich Beck, Risk Society, Londres, Sage, 1992; Anthony Giddens, Ulrich Beck, Scott Lasch, Reflexive Modernization, Londres, Polity, 1995. 
como sinônimo de exclusão e dualismo selvagem. Assim, arremata seu penúltimo livro profetizando a brasilianização da Europa, caso esta não se decida por um new deal contra a exclusão social - entre as gerações, entre os ocupados e os desempregados, etc. ${ }^{91}$ Nessa fantasia, o monopólio estatal da violência terá sido abolido; o Estado-Social estará em ruínas, mas não impera a desordem, ou melhor apenas nos territórios intermediários que juridicamente não pertencem a ninguém, pois nos demais - unidades de poder conflitantes que se defendem e se enfrentam, Estados que representam interesses particulares de interessados particulares - reinam, confusamente delimitados, grandes empresas internacionais, cartéis de drogas, exércitos de libertação nacional, militantes ambientalistas, etc. Nestes Estados residuais ainda se arrecadaria impostos, mas na forma de pagamentos voluntários ou doações institucionais. Encimando a projeção deste cenário, variantes estilizadas da atual cleptocracia global; por exemplo, circunstâncias em que se permite roubar livremente, inclusive por razões terapêuticas, sem falar em regiões nas quais se poderá adquirir e consumir sem restrições entorpecentes, aliás um velho tópico programático liberal. Neste último item, nossa imaginação nacional terá sido talvez mais exata. Num filme brasileiro recente, sem dúvida o mais importante da década - o que não chega a ser propriamente um elogio, em vista da indigência característica de um período de regressão em todos os níveis -, Cronicamente inviável, de Sérgio Bianchi, uma jovem senhora de sociedade, de passado possivelmente esquerdista e presente filantrópico, acha que o Estado deveria distribuir gratuita-

91. Cf. Ulrich Beck, O que é globalização?, São Paulo, Paz e Terra, 1999. mente crack para os excluídos: se o futuro deles é mesmo nenhum, que pelo menos sejam publicamente assistidos em sua agonia pelo paraíso artificial do poeta a título de Welfare.

Mas ao que parece essa visão de um naufrágio à la carte do Ocidente terá sido apenas um mau pressentimento. No livro seguinte de Ulrich Beck, talvez contaminado pelo otimismo oficial da Expo-2000 de Hannover, que lhe encomendou uma monografia para a Biblioteca Básica da Mostra, o Brasil reaparece elevado porém à condição de paradigma positivo do Admirável Mundo Novo do Trabalho, anunciado pelo título da obra. Tudo se passa como se bem brasileiramente nosso autor tivesse regredido da consciência catastrófica da brasilianização do Ocidente para uma amena consciência verde-amarela da globalização, mais exatamente, da dualização do mercado de trabalho. Voltamos assim a ser o País do Futuro. No caso, somos o real protótipo da Sociedade de Risco a caminho. Quem diria: nossa modernização de rattrapage acabou entroncando na Segunda Modernidade, a dinâmica reflexiva e triunfante da "modernização da modernização" manifestou-se finalmente na "desordem" de uma sociedade periférica, por definição inacabada. Queimando outra vez etapas, nos vemos de novo na vanguarda, quer dizer, na vanguarda da "superação" do regime de plena ocupação do trabalho no Ocidente. "O Brasil desafia a imaginação sociológica como um laboratório único, no qual nossas certezas se desfazem. A metáfora da brasilianização busca traduzir este movimento (...) O problema da brasilianização é a diferença entre a Primeira e a Segunda Modernidade, que é a simultaneidade do risco global, como prova a desagregação do mundo do trabalho e a 
universalização do desemprego". ${ }^{92}$

A essa altura o risco poderia ser grafado com maiúscula como uma categoria ontológica do famigerado estar-no-mundo, como nos bons tempos da descoberta existencialista da Finitude e seus derivados. Assim, enquanto na Primeira Modernidade tudo era uma questão de segurança, certezas e demarcações nítidas entre o sim e o não, agora, da economia à intimidade, tudo se encontra sob o novo regime do risco. Sobretudo a compra e venda da força de trabalho, domínio no qual passamos a exportar know how em matéria de flexibilidade máxima. E pouco importa se para milhões de brasileiros as

92. Cf. Ulrich Beck, The brave new world of work, Londres, Polity, 2000, notadamente capítulos 1 e 6 . Para um breve resumo do argumento, cf. artigo do mesmo autor no New Statesman, 05.03.1999, "Goodbye to all that wage slavery". Ver ainda a entrevista com o autor feita por José Galisi Filho para a Folha de São Paulo, 23.05.1999, que aliás a certa altura lhe pergunta porque exatamente "brasilianização" e não, por exemplo "mexicanização"? Com efeito, embora o PIB mexicano tenha crescido "assombrosos" $7,8 \%$ no primeiro semestre de 2000, o último levantamento de distribuição de renda e riqueza (INEGI de agosto de 2000) mostrava que o fosso entre ricos e pobres aumentara ainda mais, a ponto de alguns especialistas estimarem que a rigor mais de $2 / 3$ da população mexicana já se encontrava abaixo da linha de pobreza, concluindo que desde a desvalorização cambial de 1994 a classe média fora aos poucos destroçada, tornando o México um país que passara a ter só ricos e pobres, sem uma camada intermediária. Enfim, dois Méxicos. (Não deixa de ser intrigante, seja lembrado de passagem, que alguns teóricos brasileiros, por isso mesmo heterodoxos, tenham recentemente ressaltado não só a centralidade da classe média brasileira, mas ancorado seus respectivos projetos de renascimento nacional no reencontro dessa mesma classe média rediviva com o "povo", o qual obviamente estaria muito longe da decomposição por entropia ou anomia, como se divulga nos clichês da elite, no dizer deste mesmos teóricos). O mesmo José Galisi Filho entrevistou a respeito o atual Ministro do Trabalho da RFA, para o Jornal do Brasil, do qual obviamente recebeu uma resposta oficial: depois de admitir que a era clássica do pleno emprego chegara ao fim, que uma crescente maioria de trabalhadores apresenta uma "biografia descontínua", o Ministro se recusou a endossar a opinião de que daqui há dez anos um entre cada dois alemães ocupados trabalharia em "condições brasileiras". De certo não compreendeu que tais condições se referiam à ascensão do novo homem, o Homem Flexível, cuja maleabilidade à brasileira estaria desenhando um novo modelo alternativo de ocupação, característico dos flextimers, algo que sem o saber parece que sempre fomos, flexíveis de nascença, quem sabe nos termos clássicos do pensamento brasileiro referidos acima. tarefas da Primeira Modernidade ainda são uma pauta eternamente adiada, pois o raciocínio não é etapista, e está mais para pastiche involuntário de uma revolução permanente, se não à maneira bolchevique, pelo menos, de decalque em decalque, ao modo do Alto Modernismo brasileiro, quando este fantasiava juntar performance high-tech ao nosso reservatório pré-burguês de desordem colonial. Pensando bem - estamos diante de um outro episódio de acerto involuntário -, o pressentimento de uma flexibilização à brasileira do mundo não chega a ser um despropósito, desde que se inverta o sinal das duas variáveis, qualificando melhor a desordem efetivamente gerada pela flexibilização. Como fez, por exemplo, Richard Sennett, no sentido da alienação crescente do sujeito que se "dobra" e se ajusta ao rebaixamento do meio em mudança: o que no topo da hierarquia do capitalismo flexível se apresenta como poder para prosperar no caos das empresas tecnológicas em expansão, se manifesta como compulsão auto-destrutiva dos que trabalham mais embaixo no regime flexível. ${ }^{93}$

Obviamente Ulrich Beck não é o primeiro a celebrar a presumida revolução copernicana operada pelo emprego flexível. Tampouco é o primeiro a lembrar o quanto esta fragilização de massa se deve à avassaladora feminização da força de trabalho, cuja dupla jornada pedia no limite horários mais elásticos de extração de mais-valia. ${ }^{94}$ Porém inova quando assimila uma tal feminização

93. Cf. Richard Sennett, The corrosion of character - the personal consequences of work in the new capitalism, NY, Norton, 1998, pp.46-63.

94. Pois afinal é disso que ainda se trata, como demonstrou faz tempo, David Harvey, entre outros estudiosos da chamada acumulação flexível. Cf. The condition of posmodernity, Oxford, Blackwell, 1989. Demonstração acrescida da novidade não prevista pelos que à esquerda sempre apostaram no caráter 
- para não falar na correspondente etnização da mão de obra imposta igualmente pela corrida ao corte de custos - à síndrome geral a que se está dando o nome de brasilianização. Desde é claro que se chame a flexibilização pelo seu verdadeiro nome brasileiro, a saber: um agravamento tal da espoliação e desamparo dos indivíduos flexibilizados a ponto de assumirem cada vez mais os traços dos "homens precários" da periferia. ${ }^{95}$ Precários, porém altamente maleáveis e plásticos na sua informalidade de nascença. Esse o ponto ótimo embora cego da nova apologética: desentranhar do processo metropolitano de "corrosão do caráter" pela Sociedade de Risco a exuberância sem nenhum caráter do povo miúdo da antiga franja colonial do sistema.

\section{O mundo sem culpa (II)}

intrinsecamente progressista do capitalismo, a saber o retorno de estratégias de extração de mais valia absoluta, propiciado pelo desenvolvimento de novas tecnologias de organização da produção, que por sua vez, agora sim, como era de se esperar, exponenciou a valorização da nova força de trabalho intelectual, valorização política inclusive, como instrumento privilegiado na desmoralização do sindicalismo de conflito. O regime dito de acumulação flexível resultaria da recombinação destas duas estratégias clássicas, porém em condições tais que diferentes sistemas de trabalho alternativos podem existir lado a lado no mesmo espaço, assegurando ao empreendedor capitalista uma tal liberdade de escolha entre modos aparentemente incongruentes de exploração econômica como só se vira até então nas industrializações periféricas. Daí a forte impressão de dualização subdesenvolvida que provoca o espetáculo oferecido pela "desordem" do capitalismo antes organizado, pelo menos no Centro.

95. Título de um livro pioneiro de Flávio Aguiar sobre o teatro de Qorpo Santo, escritor brasileiro do século XIX que elevou à enésima potência o nonsense ideológico do "viver em colônia", força bruta do trabalho compulsório incluído, ao lado da insanidade "sistêmica" dos pacholas de todo o tipo, germinando na terra de ninguém entre os dois fronts da fratura colonial.
Na verdade, deu-se mesmo um encaixe pelo qual ninguém podia esperar. A alegada contaminação legitimadora da acumulação flexível pela fluidez da boa alternância brasileira de ordem e desordem, vanguarda produtiva e retaguarda social, veio de fato estilizar a convergência entre duas modernizações abortadas, ou consumadas, tanto faz, confluência entre o desaburguesamento das elites globais e o "mundo sem culpa" plasmado na outrora promissora quase-anomia periférica. É que neste meio tempo os desclassificados da ordem colonial tornaram-se absolutamente modernos.

No âmbito da tradição crítica brasileira que estamos repassando, o primeiro a assinalar a metamorfose do malandro, ou mais exatamente o comentário impiedoso da atualidade sofrido pelas perspectivas sociais projetadas pela Dialética da Malandragem, foi o crítico literário Roberto Schwarz, não por acaso, repito, derradeiro representante dessa mesma tradição. "O ensaio de Antonio Candido foi publicado em 1970, e a sua redação possivelmente caia entre 1964 e o AI-5. Nesse caso, a reivindicação da dialética da malandragem contra o espírito do capitalismo talvez seja uma resposta à brutal modernização que estava em curso. Entretanto, a repressão desencadeada a partir de 1969 - com seus interesses clandestinos em faixa própria, sem definição de responsabilidades, e sempre a bem daquela mesma modernização - não participava ela também da dialética de ordem e desordem? É talvez um argumento indicando que só no plano dos traços culturais malandragem e capitalismo se opõem..."96 Isso observado por volta de 1978. Verificação ainda mais enfática no início dos anos 90, uma década depois do desengano desenvolvimentista, a propósito de um

96. Roberto Schwarz, "Pressupostos, salvo engano, de 'Dialética da Malandragem'”, in Que Horas São?, São Paulo, Cia. das Letras, 1987, p. 154. 
importante ensaio de interpretação do Brasil ainda inspirado pelo finado projeto modernista de incorporação dissidente da herança colonial pré-burguesa, de costas, todavia para o que tal herança efetivamente veio a ser, bem como seus portadores originais. Estes últimos, "segundo a fórmula de um observador recente, são sujeitos monetários sem dinheiro, num quadro de que a contravenção e o gangsterismo fazem parte tão estrutural quanto o encanto da cultura iletrada (...) sem prejuízo da graça e do alento utópico, o nosso fundo não burguês se mostrou apto, também, a servir de legitimação ao capitalismo sem lei nem cidadania trilhado no país". ${ }^{97}$

O mais surpreendente no entrecruzamento que estamos examinando, desta vez na opinião insuspeita da apologética metropolitana, é que o capitalismo com lei e cidadania no núcleo orgânico está cada vez mais parecido com a nossa malandragem agora ultramoderna. Não deixa de ter sua graça ser convidado a reconhecer alguns estereótipos da extinta malandragem nacional encravados na fluidez conexionista encarnada pelo novo paradigma da Sociedade em Rede. Graça além do mais reforçada pela demonstração do efeito de economia moral oposto, como no referido argumento crítico de Luc Boltanski e Ève Chiapello, que, no melhor estilo da Ideologiekritik de extração materialista, tomam ao pé da letra os enunciados práticos do mundo conexionista. Veja-se, por exemplo, a análise dos comportamentos ditos "oportunistas" dos networkers e suas implicações enquanto modalidade de exploração

97. Idem, "Discutindo com Alfredo Bosi", in Seqüências brasileiras, ed.cit., p.70. O autor da fórmula, "sujeitos monetários sem dinheiro", quer dizer, ex-proletários virtuais, é o teórico alemão Robert Kurz, revelado no Brasil pelo outro Roberto, é sempre bom lembrar, se é fato que essa gravitação conjunta é parte do argumento. econômica em rede, à medida mesmo em que desencadeia processos de exclusão diminuindo a "empregabilidade" dos demais membros de um coletivo de trabalho. Num estudo anterior sobre as situações emotivas que se estavam cristalizando na variante italiana da acumulação flexível, Paolo Virno também notara o quanto a versatilidade adaptativa exigida pela nova dependência do trabalho - a que se resumiria a falsa liberação pós-taylorista - equivalia a um certo oportunismo militante, além do mais expressão paradoxal de um arranjo para nós familiar: o "profissionalismo" apregoado pelos flexibilizadores nada mais seria do que uma estilização cínica das qualidades de sobrevivência apuradas durante os períodos prolongados de precariedade, ou simplesmente de pré-trabalho. ${ }^{\mathbf{9 8}}$

Um último flagrante dessa metamorfose dos habitantes do "mundo sem culpa", o mesmo Roberto Schwarz voltou a colher numa das mais importantes obras literárias da década de 90, o romance Cidade de Deus, de Paulo Lins, sobre a expansão e mutação histórica da criminalidade no Rio de Janeiro. Já nas páginas de abertura, o crítico reencontra as pautas clássicas da vida popular brasileira, onde "em boa paz e sem susto para a consciência, o pé na irregularidade convive com a disposição prestativa”, mas só até que essa constelação cordata e otimista seja contestada pela "pobreza, o desemprego e, sobretudo, pelos primeiros cadáveres boiando no rio que corre ao lado da favela. O aspecto da vida popular que irá prevalecer é outro." $\mathrm{Na}$ primeira seqüência de assalto, a um prosaico caminhão de gás vendendo botijões aos moradores, os bandidos chutam a cara de um "trabalhador" que, deitado no chão, tentava esconder o dinheiro: “a palavra 'trabalhador' torna

98. Cf. Paolo Virno, Opportunisme, cynisme et peur, Paris, L’Éclat, 1991. 
mais condenável a violência dos bandidos? Ou pelo contrário, ela escarnece do otário que os quis enganar? Impossível dizer. A ambivalência no vocabulário traduz a instabilidade dos pontos de vista embutidos na ação, um certo negaceio malandro entre ordem e desordem - para retomar noutra etapa a terminologia de 'Dialética da Malandragem'. Aliás, os mesmos assaltantes franqueiam os botijões de gás ao pessoal assustado, que saía de fininho mas num minuto leva toda a mercadoria."99 Continuamos assim no coração da dualidade brasileira, mas agora entendida como a experiência formadora de matriz popular, como vimos nos termos clássicos de Antonio Candido, uma espécie de "balanceio entre o bem e o mal, compensados a cada instante um pelo outro sem jamais aparecerem em estado de inteireza", de sorte que os pares antitéticos das sociedades consolidadas - lícito ou ilícito, moral ou imoral, justo ou injusto, etc. - se mostram reversíveis e não estanques, imunes à racionalização ideológica clássica das antinomias, convivendo por aqui num curioso lusco-fusco ${ }^{100}$. Só que assustadoramente convertida no seu avesso complacentemente autodestrutivo. Nada mais flexível do que a precariedade ocupacional de um "bicho solto"101 e sua respectiva sociedade de risco.

Se passarmos ao polo das elites, iremos nos deparar com a mesma malandragem, só que agora a serviço da Ordem. Neste capítulo é bem possível que também nos reconheçam algum pioneirismo em matéria de degradação

99. Roberto Schwarz, "Cidade de Deus", in Seqüências brasileiras, ed.cit., pp. 163-164.

100. Cf. Antonio Candido, op.cit., p.48.

101. Na tipificação hierárquica dos bandidos na sociedade "relacional" da Cidade de Deus. avant la lettre, a saber, as conseqüências sociais devastadoras da "margem de liberdade absurda e anti-social de que a classe dominante, fortalecida pelo seu canal com o ‘progresso' do mundo moderno, dispõe no país"102 . Como nossa burguesia nunca se pautou, nem poderia, salvo por motivos suicidas, pelo austero ethos weberiano da acumulação, sua dualidade rebaixada - um pé no patrimonialismo local, outro nas trocas transatlânticas modernas - por assim dizer antecipara a desmoralização contemporânea das finadas burguesias mundiais. Recentemente Francisco de Oliveira cunhou a expressão "síndrome russa" para caracterizar as privatizações brasileiras ainda em curso - o vendedor também costuma passar para o outro lado do balcão como comprador -, mas não seria exagero reconhecer a marca indelével da hoje decantada flexibilidade brasileira no cenário pós-soviético em que gravitam os "capitalistas sem capitalismo": uma boa pesquisa comparada poderia descobrir coisas do arco da velha em termos de ambivalência malandra na desordem da Europa Oriental. Mas não é preciso ir tão longe. ${ }^{103}$ De modo geral, o lusco-fusco malandro, a promíscua alternância do lícito e do ilícito, se deixam reconhecer em estado bruto na delinqüência financeira de hoje, possivelmente outro sintoma aparatoso da brasilianização do mundo. Penso, entre outros detalhes edificantes para um brasileiro, numa

102. Roberto Schwarz, "Um seminário de Marx", in Seqüências brasileiras, ed. cit., p. 103.

103. Uma boa amostra do modus operandi do Estado em Rede - na mirabolante conceituação de Manuel Castells e associados - pode ser encontrado no último escândalo da República, um tenebroso affaire de alta traficância na Secretaria Geral da Presidência da República. Para um comentário das implicações sistêmicas dos negócios globalizados com fundos públicos, ver o artigo de Francisco de Oliveira, "As Caldas de Pereira: o escândalo globalitário", Folha de São Paulo, 17.08.2000, p.I-3. 
observação da juíza Eva Joly, acerca de sua dificuldade em enquadrar como réu um criminoso de colarinho branco, ou melhor monocromático - personagem hoje inviável sem a associação com o alto preço das decisões dos políticos sobre privatizações e concessões de serviços públicos -, sobretudo quando se tem em mente que para a tradição jurídica iluminista o criminoso era antes de tudo vítima de suas circunstâncias. Ora, o novo delinqüente econômico - nosso flexível malandro da ordem e da desordem mundiais - apresenta pelo contrário um percurso institucional notável pela superadaptação, precisamente de uma incomparável e bem brasileira "naturalidade"104.

Faltou acrescentar enfim, nesta série de invalidações sucessivas da lógica nacional do amaciamento dos conflitos e correspondente relativização dos pólos antagônicos, que por sua vez a ressalva pela qual começamos - que em comparação com os sistemas sociais rígidos, como o americano, o futuro está mais para as sociedades relacionais como a nossa -. em particular, as grandes mediações evocadas pelo antropólogo Roberto Da Matta, positivando o juízo negativo acerca do abrasileiramento das desigualdades americanas, como o carnaval, música popular, a família, etc., tal ressalva, repito, acaba de sofrer igualmente, por assim dizer no plano mais contundente das imagens, outro comentário implacável da atualidade. Refiro-me ao filme já citado de Sérgio Bianchi, Cronicamente inviável, começando pela revelação da fabricação da açucarada "ditadura baiana da felicidade", passando pelo esvaziamento social-familista da utopia carioca da Bossa Nova

104. Me apoio na resenha de Notre affaire à tous (de Eva Joly, Paris, Les Arènes, 2000), de Alcino Leite, Folha de São Paulo, 30.07.2000, Caderno Mais! p.30. e culminando numa grandiosa pancadaria em família, distribuída eqüitativamente entre o filho espancador de trombadinha e o romance da empregada doméstica disposta a abrir o bucho de Madame, aliás sua companheira de infância e Casa Grande na Gávea. De resto, boa parte das seqüências são montadas pelas andanças de um antropólogo pelo país do extermínio que vem a ser atualmente o Brasil, cuja duvidosa clarividência intelectual se casa sem maiores atropelos com o tráfico de órgãos, pois ninguém é de ferro e sempre se carece de uns trocados para arredondar o orçamento. O que não deixa de ser uma volta a mais no parafuso da reversão histórica da picaresca nacional.

Subindo novamente ao andar de cima, a alternância de ordem e desordem tornou-se enfim ressentimento ostensivo, a ponto de se tornar traço fisionômico de classe, na boa observação do crítico de cinema Ismail Xavier, num balanço recente da cinematografia brasileira dos anos $90 .{ }^{105}$ Aliás, depois de passar em revista a expressiva galeria de ressentidos na filmografia do período, Ismail Xavier chega a sugerir que a figura do ressentimento talvez tenha se tornado uma categoria chave para o diagnóstico nacional, como se todos ruminassem uma desfeita histórica qualquer, com a natureza da qual infelizmente não é muito difícil atinar. Houve uma explosão, e em meio aos estilhaços "o nacional é experiência à revelia (que) no entanto se impõe, pela própria estrutura do filme [de Sérgio Bianchi], como um território e como uma sina, como a mesa do restaurante". Voltando à desautorização histórica do mito da terra sem mal, por motivo de frouxa interiorização da Lei, o filme toma o cuidado de distinguir o ressentimento dos opri-

105. Cf. Ismail Xavier, "O cinema brasileiro dos anos 90 ", revista praga n.9, São Paulo, Hucitec, 2000. 
midos da sua versão classe alta. A qual não se conforma, por exemplo, com a vergonha permanente do lugar onde vive e aspira pelo menos à violência civilizada do Primeiro Mundo, por contraste com a violência sans phrase dos subdesenvolvidos, cuja encantadora desordem de outrora teria se tornado sinônimo da mais bruta incivilidade, uma obsessão, esta última, ao longo de todo o filme. Há também, noutra observação preciosa de Ismail Xavier, a revelação de uma certa "incompetência" na origem do ressentimento dos de cima. Na hora do brinde à Nova York, estão reunidos à volta da mesa do restaurante politicamente correto, pelo menos um humilhado por assalto e outro estropiado por acidente de trânsito pouco europeu. Ressentimento a meio caminho da amargura do patrão decepcionado - como Antonio Candido caracterizou certa vez a imagem do caipira desvitalizado e retrógrado criado por Monteiro Lobato - e da inépcia truculenta de uma camada dirigente a um tempo maligna e bisonha, na opinião, insuspeita de esquerdismo, de um Celso Furtado, por exemplo, logo depois de nosso acordo falimentar com o FMI: "existe uma espécie de estratégia com respeito ao Brasil, comandada pelos Estados Unidos e baseada na idéia de que o Brasil demonstrou incapacidade de se governar. Um país com tantas possibilidades e que se afunda tanto tem uma classe dirigente inepta. Para mudar isso é preciso tirar dessa classe dirigente o instrumento da política monetária. Com a dolarização, o sistema monetário passaria a ser administrado pelo Federal Reserve, que é o Banco Central dos Estados Unidos. Essa é a própria essência da globalização."106

Voltemos ao hemisfério superior da Ordem, tomando-a agora na sua acepção mais encorpada, à esfera

106. Celso Furtado, entrevista à revista Bundas, 12-19 de outubro de 1999, p. 11. simbólico-normativa da Lei que nunca foi plenamente introjetada na organização subjetiva dos figurões nacionais e sua clientela, pelo menos não na intensidade e convicção desejada pelos freudianos - como lembrado, a norma burguesa da subjetividade mais exigente não era mesmo conosco. ${ }^{107}$ A começar pelo psicanalista malandro que negocia o preço da sessão com ou sem nota fiscal. Assim, na opinião de um ex-ministro dos tempos do Plano Cruzado - nosso derradeiro espasmo desenvolvimentista -, comentando o mesmo filme de Bianchi, que obviamente, lhe falou à imaginação num país de sonegadores assumidos: "na hora do perigo, do acidente, do assalto ou da redenção, se mostram como são: roubam, salvam o seu e fogem", e mais importante, "fazem quase tudo legalmente". ${ }^{108}$ Lato sensu, é claro: relembro que estamos falando da Lei e da Ordem num mundo sem culpa, e cujo desajuste no plano global está emprestando um novo significado à desordem do nosso progresso de antigamente.

De volta ao filme: "duas dondocas atropelam mendigos e, em vez de socorrerem as vítimas, produzem discursos bem articulados em que se isentam de culpa"109. Aberrações à parte, a grande novidade está precisamente nessa "articulação", na desenvolta capacidade intelectual para "formular", coisa inédita à vista da tradicional boça-

107. Cf. Sérvulo Augusto Figueira, "Machado de Assis, Roberto Schwarz: psicanalistas brasileiros?”, in Nos bastidores da psicanálise, Rio de Janeiro, Imago, 1991.

108. João Sayad, “Cronicamente inviável”, Folha de São Paulo, 10.07.2000, p.D-2.

109. Luis Zanin Oricchio, O Estado de São Paulo, 14.05.2000, p. D-6. "Quase todos os personagens do filme, na verdade, estão às voltas com o mesmo problema: o de livrar-se de qualquer responsabilidade pelos horrores que acontecem no país”, Marcelo Coelho, Folha de São Paulo, 10.05.2000, p. E-10. 
lidade de nossa gente fina, possivelmente o mais precioso legado da atual elite dirigente para a história da civilização brasileira: diante da série de horrores do cotidiano nacional, todos "formulam" muito bem. Continuando: "[uma delas, a dondoca professoral] afirma que não tem culpa se o atropelado desrespeitou a lei, que não é possível viver num país no qual as pessoas não tem a mínima noção de contrato social"110. Na verdade, pelo menos neste tópico da culpabilização dos indivíduos empurrados para as margens do sistema, por inimpregáveis e insolváveis não temos total primazia, bem como no que concerne à correspondente irresponsabilização dos grupos dirigentes que aparentam barganhar, em nome da choldra inepta e desdentada, com o vasto mundo da riqueza cosmopolita. Não custa lembrar, para voltar ao ponto, mais exatamente a um outro ponto em que parecem convergir o mundo sem culpa da elite brasileira e o mundo do trabalho europeu culpabilizado pelo seu próprio desmanche, que, se é certo que a crescente irreponsabilização do comando político-econômico no Brasil tem raízes locais, reforçadas hoje, como se viu, pelo livre acesso patrimonialista ao dinheiro mundial, algo terá a ver com o novo ethos da reestruturação produtiva de cunho gerencialista-flexível, cujo ponto de honra consiste justamente no domínio da arte de exercer o mais incontrastado poder sem ser responsabilizado por coisa alguma que não seja debitado à rediviva "força das coisas", do chão de fábrica aos gabinetes ministeriais. Desse novo habitus decorre a famigerada "arrogância" da nova classe dirigente, com a qual aliás se chocaram de frente os grevistas franceses de 1995. ${ }^{111}$ Uma outra figu-

110. Luis Zanin Oricchio, loc.cit.

111. Cf. Jean-Pierre Le Goff, "Le grand malentendu”, in Jean-Pierre Le Goff/ ra da fuga à responsabilidade - só a "mudança" é o agente responsável, observa por sua vez Richard Sennett, a propósito da demagogia antiautoritária de que trabalho e capital jogam agora no mesmo time: se todo mundo é vítima de sua época, a autoridade se torna invisível - é a ironia branca dos pós-modernos. Assim, o homem irônico, transformado por Richard Rorty em herói intelectual do nosso tempo nada mais é do que a transposição highbrow do universo, sem padrão de autoridade e responsabilidade, da acumulação flexível. ${ }^{112}$ Nesse jogo do poder irresponsável, a ironização das condutas obviamente se bifurca: para cima, a autoridade descaracterizada pela alegação de que os processos destrutivos em curso são comandados pela ironia objetiva das coisas, cega por definição; para baixo, a auto-desmoralização da dissidência. Pois na periferia, a Dialética da Malandragem, agora na berlinda mundial, também poderia ser decifrada nos seus primórdios carregados de futuro como uma sorte de ironização permanente das motivações, com a ressalva que o desafogo prometido deu no que estamos vendo.

O crítico de cinema Paulo Emílio Salles Gomes costumava se referir às classes fundamentais de uma periferia em que a condição colonial era reconfigurada à cada variação do centro hegemônico mundial, como "ocupante" e "ocupado". Mais do que nunca vale a pena reler o trecho premonitório à luz da atual regressão colonial, con-

Alain Caillé, Le tournant de décembre, Paris, La Découverte, 1996; do mesmo Le Goff, ver L'Illusion du management, Paris, La Découverte, 1998. Relembro mais uma vez que a matéria bruta ideológica da qual Luc Boltanski e Ève Chiapello desentranharam as linhas de força do Novo Espírito do Capitalismo provém sobretudo do jargão do management flexível.

112. Cf. Richard Sennett, The corrosion of character, ed.cit., cap.6. 
forme vão avançando as fronteiras imateriais do novo imperialismo, as que verdadeiramente contam, o resto são encargos fiscais-repressivos da administração local: "nunca fomos propriamente ocupados. Quando o ocupante chegou o ocupado existente não lhe pareceu adequado e foi necessário criar outro (...) A peculiaridade do processo, o fato do ocupante ter criado o ocupado à sua imagem e semelhança fez deste último, até certo ponto, o seu semelhante. Psicologicamente, ocupado e ocupante não se sentem como tais: de fato, o segundo também é nosso e seria sociologicamente absurdo imaginar a sua expulsão como os franceses foram expulsos da Argélia (...) O quadro se complica quando lembramos que a Metrópole de nosso ocupante nunca se encontra onde ele está, mas em Lisboa, Madri, Londres ou Washington (...) Basta por ora atentar para a circunstância de o emaranhado social brasileiro não esconder, para quem se dispuser a enxergar, a presença em seus postos respectivos do ocupante e do ocupado." Isto dito em 1973. ${ }^{113}$ A atual dessolidarização pós-nacional acabou fazendo justiça à verdade daquele anacronismo. Vinte anos depois, Celso Furtado reparava que os ricos nacionais, por assim dizer baseados no Brasil, voltaram a ser vistos como habitantes de outro planeta. ${ }^{114}$

\section{"Nós ćramos e somos ilegais"(I)}

113. No primeiro numero da revista Argumento, recolhido depois em Paulo Emílio, Cinema: trajetória no subdesenvolvimento, São Paulo, Paz e Terra, 1980, p. 77.

114. Cf. Celso Furtado, O capitalismo global, São Paulo, Paz e Terra, 1998, p.40.
Pode-se dizer que os estudos recentes da urbanista Ermínia Maricato estão passando a limpo a matriz brasileira dessa segunda periferização do mundo. Estou me referindo em particular a um livro - A metrópole na periferia do capitalismo ${ }^{115}$ - cujo título (parafraseado lá na frente, como o leitor terá por certo notado) enuncia precisamente esse "curto circuito entre metrópole e periferia"116, as quais em princípio não poderiam andar juntas. Mas ao se juntarem nas megacidades do capitalismo periférico - quer dizer, de um lado um arremedo de cidade global servindo de isca para atrair investidores internacionais, de outro, o inchaço entrópico de pobreza e desamparo das periferias--, revelam o fundo falso, ou melhor, verdadeiro, do "mundo sem culpa" na sua mais avançada reconfiguração, uma outra atualização, desta vez urbana. Pois Ermínia Maricato simplesmente reencontrou o fio malandro da ordem e da desordem na urbanização à brasileira, por sinal o mesmo que o crítico literário Roberto Schwarz - cujos esquemas lhe serviram de sonda - redescobrira no narrador machadiano, o figurão de nosso antigo regime liberal-escravista, empenhado em demonstrar sua superioridade ora acatando a norma culta do mundo europeu, ora afrontando e desacreditando suas mesmas fumaças civilizadoras. Valeria assim para a produção capitalista do espaço na cidade o mesmo rebaixamento contemporâneo daquela mesma alternância outrora popular entre o lícito e o ilícito, agora na forma de uma articulação perversa entre poder público arbitrário e relegação social.

Resenhando livremente o livro, Otília Arantes - cujo comentário passo a acompanhar ao pé da letra - sugeriu

115. São Paulo, Hucitec, 1996.

116. Como o caracterizou Otília Arantes, a cuja resenha me reportarei a seguir. 
que a seguinte constatação bem poderia servir-lhe de epígrafe: "nós éramos e somos ilegais". ${ }^{117}$ A fala é de um ex-favelado e exprime o desalento de um homem precário, cuja posse ilegal de um lote clandestino deixa-o à mercê de toda sorte de arbitrariedades - da polícia ao judiciário. Ocorre que esse infrator nato e indefeso é incentivado pelo próprio Estado, e suas ramificações no submundo dos negócios imobiliários, a prosseguir na ocupação ilegal do solo, com a ressalva malandra, própria de uma sociedade que conjuga sem exclusivismos o sim e o não, e cultiva a flexível ambivalência das zonas intermediárias entre o certo e o errado: a legislação tanto pode ser aplicada ou não ser; ora vale a informalidade clientelista, ora as leis do mercado. Continuo citando. Passando para o polo dominante, a mesma declaração pode ser relida em chave cínica. Aqui o jogo entre a exceção e a regra prossegue na contravenção sistematicamente praticada pelas elites. É sempre bom lembrar que estreamos na vida soberana como um Estado negreiro, um infrator nato também, no caso, das leis internacionais contra a pirataria. Completando o raciocínio, o fecho da brasilianização do mundo: na última década, os organismos multilaterais passaram a recomendar a regularização à brasileira dos assentamentos espontâneos (sic), também à brasileira. Em suma, dialética da malandragem em escala global.

\section{"Nós éramos e somos ilegais" (II)}

117. Cf. "Pobre cidade grande", Jornal de Resenhas 10.05.97, depois recolhido no volume de ensaios, Urbanismo em fim de linha, São Paulo, EDUSP, 1999.
A consumada modernidade flexível então é isso que se está vendo no velho laboratório brasileiro da mundialização: esse entra e sai na esfera peculiar dos mais diversos ilegalismos, tanto no plano da mera viração dos despossuídos, quanto no âmbito da alta transgressão que distingue os pilares da sociedade nacional. Acrescido o conjunto de uma outra contribuição igualmente idiossincrática, a aplicação caprichosa da lei ${ }^{118}$, arbitrariedade que, no caso, deveria paradoxalmente regular a produção do espaço urbano. Assim, ainda na observação da mesma Ermínia Maricato, o regime altamente flexível que vigora nesta terra de ninguém que é a cidade ilegal não só demanda, e por isso mesmo, um aparato regulatório inchado no limite do surreal, como convive muito bem com este seu par alterno.

Pois essa mesma "fúria regulatória" se manifesta igualmente no desmanche do mundo brasileiro do trabalho, além do mais regida ela também pela mesma lógica dual que estamos redescobrindo na síndrome da brasilianização do mundo. Até onde sei, a evolução dessa outra anomalia local vem sendo acompanhada por um grupo de pesquisadores da "nova questão social" brasileira, como denominam o amálgama da pobreza "atrasada" com os novos deserdados da reestruturação produtiva global, do qual resulta um pacote moderno de "excluídos" reconduzidos à condição natural de paisagem. ${ }^{119}$ Está claro que à vista

118. Wanderley Guilherme dos Santos fala de "punição aleatória e penas erráticas", a propósito do hibridismo institucional brasileiro, in Razões da Desordem, Rio de Janeiro, Rocco, 1993, cap.3. A seu ver o Brasil da recém inaugurada década de 90 e sua fieira de ajustes macroeconômicos, teria reativado algo como uma versão de mercado do modelo máfia.

119. No que segue me apoio sobretudo em Vera da Silva Telles: "Questão social: afinal do que se trata?", in Revista do SEADE, São Paulo, outubro-dezembro de 1996; "No fio da navalha”, paper, Instituto Polis, São Paulo, 1998. 
da espantosa instabilidade ocupacional que caracteriza o mercado de trabalho no Brasil tudo se passa como se também nesse domínio avançado da sociedade global de risco fôssemos igualmente flexíveis de nascença. Mas não é só o formidável e crescente contingente de trabalhadores que hoje transitam num perpétuo vai-e-vem entre desemprego e as mil formas de trabalho precário e que por isso mesmo vivem numa espécie de confinamento, aquém das parcas garantias sociais conquistadas pelos assalariados formais. Também estes últimos não logram escapar à malha desestruturante das ilegalidades consentidas. Pois é aqui que a mencionada "fúria regulatória" convive com a burla rotineira das normas contratuais, de sorte que por meio das práticas recorrentes de demissão o núcleo duro do trabalho organizado acaba se reencontrando com o outro extremo da informalidade. ${ }^{\mathbf{1 2 0}}$ No limite dessa trama de ilegalismos, categorias profissionais inteiras acabam simplesmente "desaparecendo", e das estatísticas e da representação sindical. Graças à terceirização predatória e suja, não estão "fora" do mercado, apenas se tornaram socialmente invisíveis $^{\mathbf{1 2 1}}$. Tal como os sem-teto, expurgados do atual Censo nacional por ordens "científicas" superiores. ${ }^{\mathbf{1 2 2}}$

Pensando bem, o admirável mundo novo do trabalho é aqui mesmo. Basta um exemplo, colhido na vanguarda

120. Do mesmo modo, um Estado altamente regulatório, segundo Wanderley Guilherme, tornou-se o criador de grupos de interesse rentistas, op.cit., 114, Fechando o argumento, Vera Telles vê no tráfico de drogas e demais manifestações do crime organizado, através dos quais os tais "excluídos" forçam a porta de entrada no mercado, uma espécie de versão popular e mais condizente do neoliberalismo - pragmático ou não.

121. Cf. Vera da Silva Telles, “Questão social: afinal, do que se trata”, loc.cit.

122. Folha de São Paulo, 19.09.2000, p.I-4. dos flextimers. Refiro-me aos novos campeões da flexibilidade, situados bem no alto da escala das qualificações requeridas por uma economia baseada no trabalho com informação. Sob o novo regime global do risco, são aqueles que integram o coração de uma força de trabalho em permanente disponibilidade e que portanto estão a perigo, como se diz, caso não sejam conectáveis a qualquer momento e em qualquer lugar. $\mathrm{O}$ olho bem treinado do historiador brasileiro Luiz Felipe de Alencastro para as anomalias do mercado de trabalho nacional não teve dificuldade em reconhecer no último produto do lixo cinematográfico americano - "Missão impossível 2", ou coisa que o valha - uma estilização involuntária desse ultra-flexível trabalho à disposição, na figura do "mocinho" mobilizável pela rede telemática do Império em qualquer canto para salvar a humanidade, ou garantir os lucros extraordinários de sua firma. E como se trata de um olho escolado pelo secular entrelaçamento de trabalho compulsório e trabalho dito livre, sobretudo reconheceu, sob o verniz high-tech do indivíduo isolado pronto para ser empregado em qualquer circunstância, nada mais nada menos do que uma espécie de empregada doméstica à brasileira, devidamente globalizada. Pois nada mais parecido com a servidão dessa disposable labor force de última geração do que o destino emblemático da pobre criatura colonial, "alojada no quartinho do fundo da casa ou do apartamento e pronta, todo dia, toda hora, para atender os pedidos e os abusos do patrão, da madame e dos filhos da família". ${ }^{123}$ Continuamos portanto na vanguarda. Outra vez,

123. Luiz Felipe de Alencastro, "A servidão de Tom Cruise", Folha de São Paulo, Caderno Mais!, 13.08.2000, p.7. Novamente não estou dizendo nada que um cartógrafo das fraturas francesas, por exemplo, não pudesse rastrear por si mesmo. Sobretudo se o leitor de André Gorz. Na intenção do qual aproveito a 
um laboratório e tanto do famigerado desenvolvimento desigual e combinado de um capitalismo que parece continuar o mesmo. Ou não?

deixa para relembrar um passo "brasileiro" de sua crítica das falsas superações da sociedade salarial, justamente o que diz respeito à alegada passagem da sociedade industrial para a economia informacional de serviços. Quero me referir a uma outra dimensão da "dualização" das sociedade centrais, seu aspecto propriamente colonial, a ressurreição pós-moderna do trabalho servil, o trabalho da multidão pauperizada, cujo métier doravante é servir, e servir para que fique bem claro que são inferiores e que as novas hierarquias estão aí para ficar e por isso mesmo estão sendo monetizadas. Cf. André Gorz, "Pourquoi la société salariale a besoin des nouveaux valets" in Manière de Voir, n.18, 1963, pp.48-52.

\section{Nação e reflexão*}

\section{Imaginação nacional}

Costuma-se dizer com razão que Ernest Gellner revogou nossa compreensão rotineira das relações entre nação e nacionalismo ${ }^{1}$. Revirou-as de ponta cabeça, como se sabe. O nacionalismo não deveria ser explicado pela alegada existência de "nações", mas sim o contrário, e bem ao contrário do que comumente se entende como o despertar da consciência nacional: o nacionalismo não acorda uma nação entorpecida por uma alienação secular, ele simplesmente inventa a nação que antes não existia. Concentrando-se sobretudo nos fenômenos de modernização pelo alto - no que deve ter contribuído seu estágio nas antigas sociedades coloniais - Gellner acabou enfatizando "o elemento de artefato, de invenção e de engenharia social

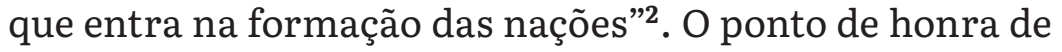
sua demonstração reside portanto na capacidade de reconstituir a cristalização das "nações" sem evocar qualquer dos estereótipos consagrados pela autoimagem do sentimento nacional: territorialidade, consanguinidade,

* Parcialmente publicado na revista Sexta-feira de 2001.

1.Thouhgt and Change é de 1964, Nations and Nationalism, de 1983, para dar duas balizas. Ver ainda a coletânea Nacionalismo e Democracia, Cadernos UnB, Brasília, 1981, Introdução de José Guilherme Merquior.

2. Eric Hobsbawm, Nações e Nacionalismo desde 1780, São Paulo: Paz e Terra, 1991, p.19. 
patriotismo, aversão ao domínio estrangeiro, cultura vernacular ou qualquer outro atavismo do gênero. No fundo, acabou derivando a ideia de nação - para não falar na sua realidade - de uma espécie de nacionalismo de elite ${ }^{3}$, e de uma elite suficientemente esclarecida em suas providências institucionais a ponto de dispensar, e no limite desacreditar, as visões românticas que costumam ornamentar esse tipo de fabricação a frio da hegemonia - para empregar um termo estranho ao vocabulário de nosso Autor. Mas não inteiramente ao espírito, pois afinal se trata da resolução do problema da legitimidade numa sociedade industrial, cuja tendência niveladora - em princípio as desigualdades óbvias de uma sociedade tradicional não são mais toleradas - pede homogeneidade social e cultural: ora é a necessidade moderna de homogeneidade que gera o nacionalismo e, mais uma vez, não o contrário.

Uma resenha menos sucinta deveria mostrar que a rigor Gellner sistematizou os traços organizacionais relevantes do Estado nacional moderno, revelando tanto a funcionalidade econômica do nacionalismo - que sai justificado do enredo contemporâneo como um princípio construtivo e progressista ${ }^{4}$, quanto sua data de validade: o processo

3. Tomando noutra direção uma observação de Merquior, à qual voltaremos, pois foi dos primeiros a notar que a ser plausível o esquema de Gellner então não haveria lugar para os movimentos nacionais da América Latina do início do século dezenove. Pelo visto o reparo sempre reaparece. Ver recentemente, Perry Anderson, "Max Weber e Ernest Gellner”, in Zona de Engajamento, São Paulo: Ed. UNESP, 1995, p.131.

4. Na avaliação de Perry Anderson, loc.cit. Não será demais relembrar a esta altura de obsolescência avançada e degradação política dos "artefatos" nacionais, que para Gellner igualitarismo e nacionalismo modernos são complementares - não que a seu ver a sociedade industrial seja igualitária na distribuição de riqueza e poder, "mas é igualitária enquanto requer que todos os cidadãos sejam da mesma espécie, sem profundas e manifestamente simbolizadas distinções de casta ou categoria social”, "As razões sociais do nacionalismo", in Nacionalismo e Democracia, ed.cit., p.89. de difusão da civilização industrial por obra justamente de "unidades nacionais", aos olhos do Autor, o evento dominante de nossa época. Ocorre que essa industrialização imperativa - os que chegarem tarde arriscam a marginalização - se alastra por uma economia-mundo cuja lei é o desenvolvimento desigual - aliás é o próprio Gellner quem o diz e não um comentador marxista simpatizante, até porque, na esteira de Gerschenkron, cujo livro sobre o "atraso econômico" é de 1962, nosso Autor também foi dos primeiros a identificar no marxismo soviético o "espírito" que teria presidido a marcha forçada da industrialização pesada, fazendo pela modernização "nacional" e "mimética" o que o calvinismo fizera para a emergência individualista do capitalismo. Ora, o nacionalismo é fundamentalmente a consequência da tensão gerada pelo desenvolvimento desigual numa economia mundial unificada, como resposta política a uma situação de "atraso" que se tornou tão inaceitável quanto a desigualdade de princípio numa sociedade industrial particular. Desse esforço recuperador surgirá então a convicção retrospectiva de que o nacionalismo não se origina das nações mas as faz nascer. Convicção datada, como se está vendo, mais exatamente, do auge da regulação keynesiana dos sistemas econômicos nacionais, cuja ascendência balizou igualmente a onda descolonizadora e industrializante nas várias periferias reestruturadas ao longo da primeira Pax Americana ${ }^{5}$. Isso tudo se foi, mas

5. Data que também transparece no comentário distanciado de Perry Anderson: hoje custa menos (?) o sarcasmo da constatação de que a disseminação do impulso de criar estados cujas fronteiras políticas não coincidem exatamente com as fronteiras étnicas gerou movimentos nacionalistas que recrutavam tipicamente entre "uma intelligentzia alheada e um proletariado desenraizado - aquele pretendendo beneficiar-se do monopólio dos cargos públicos num estado independente, e este no sentido de ser explorado ao menos por seus concidadãos", op.cit., p.130. 
os conceitos ainda fazem pensar, notadamente a ideia de que a nação e seus derivados são artefatos de um tipo bem peculiar, como logo se verá de um outro ângulo, que aliás não necessariamente encobre essa perspectiva induzida pela experiência do rattrapage econômico do pós-guerra. Resta ver se com tal ideia ainda poderemos remontar a corrente até o ciclo histórico anterior - afinal o período no qual o Brasil foi "inventado" pela primeira vez - , e de lá retornarmos, com outros olhos, ao desenlace de hoje e saber se ficaremos devendo ou não uma terceira "invenção" do Brasil. Se somos de fato um constructo, seria preciso então atinar com o "nacionalismo" muito peculiar a que devemos nosso nascimento como nação. Nos termos mesmos de Gellner, um "nacionalismo" paradoxalmente anacrônico na sua estrita funcionalidade para um sistema produtivo carecido de uma arrancada salvadora. Ou não? E se proviesse do Novo Mundo uma primeira e decisiva sugestão para a ideia de "nação como artefato" ? ${ }^{6}$ Para

6. Título do estudo de Márcia Regina Berbel sobre a atuação dos deputados do Brasil nas Cortes Portuguesas de 1821-1822, São Paulo: Hucitec, 1999 — título obviamente inspirado na constelação de ideias que está nos interessando por à prova -, no qual se faz, entre outras coisas, um inventário sistemático das diferentes acepções da palavra nação nos debates destinados justamente a "constituir a nação portuguesa", como se dizia então. Em suma, à primeira vista, "a nação era projeto político, e não era unívoca”, e sobretudo um "artefato a ser concluído”, p.29. Esta última fórmula dá o que pensar, quando mais não seja porque a rima involuntária que emenda no caráter, por definição, sempre "inconcluso" da "formação" nacional, lança pelo menos sobre a semântica desta ideia tão sobrecarregada uma conotação construtiva que atenua seu acento organicista muito forte, como é próprio aliás das evoluções subterrâneas. Isso dito também para relembrar o quanto pode haver de ilusão retrospectiva na reconstituição do "sentido" de nossa trajetória nacional feita por Caio Prado Jr., a ponto de - e agora a observação retificadora é da Autora - sucumbir à ilusão de que a reação dos "brasileiros" à política de recolonização das Cortes Portuguesas teria resultado de uma iniciativa do "conjunto do país", o que levaria enfim à "autonomia nacional", como se a Independência fosse uma revolução feita por uma "nação", e como se as elites, ainda sequer muito convictas de sua "vontade de viver juntos" (na fórmula clássica de Renan, retomada por Luiz Felipe de Alencastro) pudessem estar avant la lettre agrupadas em torno de uma "causa nacional". além é claro da constatação não tão óbvia assim porém indiscutível de que à gênese multissecular do moderno Estado nacional europeu - de cuja trajetória incerta a rigor não se pode dizer que tenha sido traçada pelas sucessivas gerações dos seus formadores - , corresponde na América, no momento, da decomposição do Antigo Sistema Colonial, uma criação deliberada de formas organizacionais e estruturas ideológicas de legitimação que pudessem ser reconhecidas como "nações", de acordo por certo com as formações metropolitanas bem sucedidas na concorrência com as formas rivais, como os Impérios ou as redes transnacionais de cidades mercantis.

Contornando a funcionalidade industrial da nação como artefato segundo Gellner - cujo hora histórica restringia-lhe o raio explicativo -, Benedict Anderson aproveitou a deixa, e assimilando a "invenção" das nações, identificada por Gellner, à "imaginação”, abriu a brecha que nos concerne ${ }^{7}$ : como foram "inventadas"

7. Num certo sentido, a unilateralidade da teoria (por outro lado muito original) de Gellner pedia um corretivo que a reequilibrasse. Pois ao sustentar, contrariando os mitos românticos compensatórios da perda de sentido inerente aos processos modernos de racionalização social, que a economia precisa de um novo tipo de arregimentação cultural, e que esta por sua vez precisa do Estado, o qual por seu turno carece da marca cultural homogênea do seu rebanho, todo este sistema de encaixes atendendo aos requisitos de um sistema produtivo industrial moderno, tudo se passa - segundo Perry Anderson -, como se Gellner, reagindo às representações consagradas do nacionalismo como "uma força atávica destrutiva e irracional", tivesse produzido algo como a sua imagem especular chapadamente oposta. Com isso, continua o comentário, teria simplesmente negligenciado a evidência esmagadora do significado coletivo que invariavelmente o nacionalismo moderno instaura quando entra em cena, a ponto de sua dimensão identitária sobrepujar a sua mera funcionalidade para o mundo social que o industrialismo criou. Uma correção no rumo do raciocínio na qual é visível o passo dado pelo outro Anderson, do cálculo de engenharia social à instituição imaginária do espaço social, que só é "nacional" se apresentar esta quarta dimensão por assim dizer transcendente. Isso dito, não se deve obscurecer a originalidade da contribuição de Gellner, de 
as nações de proprietários coloniais que emergiram em meio às rebeliões que sacudiram a luta pela hegemonia no Atlântico a partir da Independência americana de 1776? E inventadas precocemente, pois foram as comunidades creollas da América que desenvolveram bem antes da maior parte da Europa uma concepção enfática de nation-ness ${ }^{8}$. Quem sabe, uma outra e preciosa vantagem do atraso, que por certo nos daria novamente voz no capítulo, numa época de metamorfose da hegemonia do sistema mundial de acumulação e governo, sem desfecho previsível e ao longo da qual, justamente, a desintegração social - e como se há de recordar nisto a periferia largou, ou foi largada, na frente, justamente a desintegração e não mais a reforma social perma-

fato uma contribuição quando apreciada do ângulo dos últimos ressortissants de uma nação inventada. Não custa insistir que nosso primeiro Autor pelo menos formulou a boa questão - a nossa, no caso -, invertendo, como se disse, o argumento rotineiro, mais ou menos nos seguintes termos: se é verdade, e uma verdade sociológica trivial, que nenhuma formação social se reproduz sem um certo sentido de lealdade e identificação da parte de seus membros, então não deixa de ser uma primeira anomalia o fato da coesão assim produzida ser muito mais mobilizadora nas grandes unidades sociais complexas que definem o mundo moderno do que na escala local das sociedade tradicionais, de sorte que o ponto de fuga - aí o paradoxo - desse sentimento mais intenso de lealdade e identificação seja, na figura das modernas unidades políticas, pouco menos do que uma difusa e remota abstração, além do mais visadas sob o signo do anonimato, nas quais a vida torna-se assunto de contratos e contatos epidérmicos entre indivíduos que não possuem elos positivos entre si; paradoxo confirmado por uma segunda e mais eloquente anomalia, a saber, que se pode verificar historicamente que o chamado nacionalismo possui uma espécie de critério próprio de legitimidade pois não é um mero ratificador do poder político já existente, pelo contrário, chega mesmo a precedê-lo na forma de uma sensibilidade irredutível favorável a largas unidades ainda inexistentes, ou melhor que existem apenas nos devaneios dos seus futuros aderentes, cf. "Escala e Nação" in Nacionalismo e Democracia, ed. cit., pp.43-44.

8. Benedict Anderson, Imagined Communities. Reflexions on the Origin and Spread of Nationalism, Londres, Verso, 1983, $2^{\mathrm{a}}$ ed. revista e ampliada, 1991. Trad. Brasileira da $1^{\mathrm{a}}$ ed. Nação e Consciência Nacional, São Paulo: Ática, 1989, p.60. nente e, digamos progressista, passou a ser vista como normal. ${ }^{9}$ Precoces na invenção do artefato nacional, também pioneiros na experiência do seu deslocamento, para nós (mas "nós” quem?) catastrófico.

No que segue passo então a resenhar livremente o que no raciocínio de Benedict Anderson interessa mais de perto ao nosso roteiro de busca de um futuro para a imaginação nacional, começando no caso pelo passado deste futuro na berlinda. Também inverto o raciocínio, e do enigma da invenção america na da nação - aqui sim literalmente pós-colonial - remonto à definição célebre de nação como comunidade imaginada. Talvez seja desnecessário antecipar que foi precisamente tal imaginação nacional que nos permitiu a começar a pensar - e quando ela se apagar é possível que a extinção do pensamento a siga de perto, a menos de uma nova invenção de uma e outro, ou coisa que os valha enquanto impulso liberador da reflexão.

Vejamos portanto como nosso Autor enquadra o mistério da forma nacional assumida pelos movimentos de independência na América Espanhola - e por extensão na América Portuguesa. Antes porém um lembrete: é bom deixar claro que o foco na "imaginação" (ainda por definir) não dispensa, longe disso, a explicação por assim dizer material da resistência antimetropolitana no hemisfério ocidental na virada do século XVIII

9. Confira Immanuel Wallerstein, After Liberalism, NY: The New Press, 1995, p. 106. Não estou citando por acaso Wallerstein, segundo o qual, na origem deste impulso includente que hoje se esgotou e se converteu no seu contrário, encontra-se precisamente a quebra do princípio da legitimidade dinástica, suplantada pela eficácia sistêmica das soberanias nacionais como fonte do poder político responsável por algo como uma reforma social contínua. Ver do mesmo autor o último artigo da obra citada, "The agonies of Liberalism". 
para o XIX, de resto bem conhecida e incontroversa nos seus elementos básicos; o ponto é que os óbvios interesses econômicos em jogo, bem como o papel igualmente fundamental do Liberalismo e do Iluminismo na composição do arsenal ideológico mobilizado contra o Antigo regime, não podiam criar sozinhos o tipo peculiar de "comunidade imaginada" que se protegesse contra a espoliação colonial. Aliás mais de um lembrete: é bom deixar claro também que ao rever a nação como uma comunidade imaginada, o Autor em hipótese alguma está desconsiderando a evidência histórica da desigualdade de classe e da exploração econômica que caracteriza a cristalização moderna da forma-nação, na verdade está justamente considerando o mistério sociológico de exploradores e explorados só poderem imaginar a nação na figura de um "companheirismo profundo e horizontal" - em suma, como foi possível imaginar como comunidade uma sociedade antagônica? Para além da resposta óbvia: só mesmo na imaginação, pois afinal se trata de uma imaginação por assim dizer instituinte. Por fim, ao salientar que a ideia nacional, bem como os movimentos nacionalistas que a entronizaram é um artefato muito peculiar, nosso Autor está lembrando que não se pode enquadrar a nation-ness no bloco das grandes ideologias - aliás, nada exaspera tanto intelectuais cosmopolitas e poliglotas, imbuindo-os ainda mais da própria superioridade, do que o vazio, a pobreza e a incoerência conceitual do nacionalismo, em contraste com o seu poder político assustador -, devendo, pelo contrário, num espírito antropológico, ser compreendida em analogia com os sistemas culturais amplos que a precederam, a partir dos quais, bem como contra os quais, passou a existir.
Passemos então ao enigma com o qual se deparou Benedict Anderson, na origem do interesse incomum que até hoje despertam os novos Estados Nacionais americanos, na exata medida em que parece quase impossível explicá-los segundo os padrões definidos pelos nacionalismos europeus do período oitocentista clássico de Nation making, na fórmula consagrada por Bagehot. A língua, por exemplo, nunca foi um problema, nem mesmo um tópico programático naquelas antigas lutas de emancipação nacional, senhoriato colonial e camadas dirigentes metropolitanas falavam a mesma língua. Tampouco a cristalização daquelas novas nacionalidades esteve ligada ao batismo político das classes inferiores. Ocorreu justamente o contrário naquelas rebeliões de elite, salvo no caso exemplar do Haiti. Nunca foi tão grande o medo de insurreições de escravos e índios como naqueles tempos de turbulência em todo o sistema mundial. No caso da América Portuguesa então, pode-se dizer sem muito exagero, que a Independência foi feita para melhor assegurar a continuidade da escravidão. Daí o mistério: a mesma aristocracia limenha que ainda conservava bem viva a memória apavorante da jacquerie liderada por Tupac Amaru, acataria pelo menos com fervor retórico, porém sem jamais abrir mãos de suas prerrogativas de mando irrestrito, a exortação patriótica do libertador San Martin no sentido de que a partir de então não chamassem mais os aborígenes quechuas de índios ou nativos, mas de "peruanos". Assim, províncias coloniais na América Hispânica, abrangendo grandes populações oprimidas que nem sequer falavam o espanhol, se metamorfosearam em nações de creollos que deliberadamente redefiniram tais populações como compatriotas, ao mesmo tempo que tratavam como inimigo estrangeiro a mesma Espanha à qual estavam liga- 
das por um sem número de laços. Do mesmo modo, nossos mazombos se contrapunham aos reinóis portugueses e se diziam "brasileiros" como os índios que massacravam e os africanos que continuavam escravizando.

Numa palavra - para retomar o fio -, os dois fatores comumente mencionados para explicar a súbita fragmentação em dezoito Estados distintos de um Império Colonial, que tivera existência tranquila durante três séculos são rejeitados por nosso Autor que continuamos acompanhando quase ao pé da letra, como anunciado. Nem o agressivo enrijecimento do controle metropolitano, nem a voga liberal, a favor e contra - pois as políticas do despotismo esclarecido à moda de Madri também irritaram e alarmaram a classe alta creolla - ainda que fundamentais para a compreensão do impulso separatista na América Espanhola são insuficientes para dar conta do fenômeno: porque entidades como o Chile, o México, a Venezuela, etc., se tornaram não só politicamente viáveis mas também emocionalmente plausíveis?

Para começar sua resposta, Benedict Anderson remaneja um dado aparentemente óbvio, a existência das unidades administrativas coloniais que precederam as futuras repúblicas sul-americanas. Acontece que a configuração original dessas unidades era em grande medida arbitrária e fortuita. É verdade que com o correr do tempo elas se tornaram uma realidade mais estável. Todavia, nem mesmo mercados regionais, de caráter geográfico ou político-administrativo, são suficientes para criar lealdades. Quem estaria disposto a morrer pelo Mercado Comum Europeu, com ou sem Euro? Tampouco o decisivo critério de demarcação pelo contingenciamento da força de trabalho, ao qual sem dúvida coube a última palavra. Em jogo, o nexo moral demandado por Caio Prado Jr., na reconstituição de nossa transição de Colônia à Nação, que viria enfim se sobrepor ao vínculo bruto da mera exploração econômica. Também para Benedict Anderson, trata-se de saber como tais unidades político-administrativas, a um tempo praças comerciais e polos da territorialização da força de trabalho, puderam passar a ser percebidas como "pátrias" (sem humor negro, é claro), verificar enfim como tais espaços - entrecruzamento de fluxos mercantis transoceânicos e lugar de coerção política - acabaram “criando significados". Aqui talvez a mais engenhosa das explicações do Autor, que passo mais uma vez a resumir, achando impossível que ela não fale à imaginação de um brasileiro.

Reportando-se aos trabalhos de um antropólogo que estudou um tipo original de experiência geradora de significação, à “jornada” entre tempos, lugares, status, jornada que exige explicação, como por exemplo a jornada do nascimento à morte, na origem das religiões, Benedict Anderson concebeu um tipo de "peregrinação" - por analogia com as peregrinações religiosas, caracterizadas pelo movimento constante de peregrinos até o centro de uma geografia sagrada, vindos de localidades longínquas entre as quais não existia qualquer outra relação, observação que o autor manda grifar - que batizou de jornada da imaginação, no caso uma peregrinação secular mais modesta e limitada, que são as diferentes viagens propiciadas ou exigidas pelo surgimento das monarquias absolutas e dos Impérios Europeus transoceânicos. Como se há de recordar, contraposto ao particularismo da nobreza feudal, o absolutismo criou um aparato unificado de poder, e com ele a "permutabilidade interna de homens e documentos". Permutabilidade favorecida pela arregimentação meritocrática dos homens novos: as jornadas da imaginação 
eram as viagens dos funcionários do absolutismo, peregrinações inéditas se comparadas às dos nobres feudais. A jornada feudal é única, uma só viagem de ida e volta, até o centro do poder para receber a investidura e retorno aos domínios ancestrais. Já o funcionário peregrino, como não tem “pátria” com qualquer valor intrínseco, não conhecerá nenhum lugar seguro de repouso, em sua jornada toda pausa é provisória, aliás a última coisa que deseja em sua carreira é voltar para casa. "Enviado para a municipalidade de $\mathrm{A}$ no posto $\mathrm{V}$, pode retornar à capital no posto W; vai, a seguir, para a província $B$, no posto X; prossegue para o vice-reino $\mathrm{C}$ no posto $\mathrm{Y}$; e termina sua peregrinação na capital no posto Z". E mais: "em sua rota espiral de ascensão, depara-se com companheiros de peregrinação igualmente ansiosos, seus colegas funcionários, oriundos de lugares e de famílias de que nunca ouviu falar e que espera certamente jamais ter de ver. Porém, com a experiência de tê-los como companheiros de viagem, emerge uma consciência de conexão (grifo meu), sobretudo quando todos compartilham uma única língua de Estado”. E como se disse, consciência de permutabilidade - o funcionário $\mathrm{A}$, vindo da província $\mathrm{B}$, administra a província $\mathrm{C}$, enquanto o funcionário $\mathrm{D}$, da província $\mathrm{C}$, administra a província B. A expansão ultramarina, ao desenvolver enormes burocracias transcontinentais, multiplicou e encompridou as rotas dos funcionários peregrinos. E inaugurou o capítulo das preterições, as peregrinações dos funcionários creollos barrados em suas carreiras. "Se os funcionários peninsulares podiam percorrer a rota de Saragoça à Cartagena, Madri, Lima e de novo Madri, o creollo mexicano ou chileno típico prestava serviços nos territórios do México ou do Chile coloniais; seu movimento lateral era tão tolhido quanto sua ascensão vertical”.
A consciência emergente de conexão começará então a dar uma outra resposta à questão "por que estamos nós... aqui...juntos?" O raciocínio histórico clássico costuma acentuar o caráter bifronte do senhoriato colonial: ao mesmo tempo classe superior e subjugada, não obstante ser essencial à estabilidade dos negócios ultramarinos - e com isso registra a ambiguidade da independência, que não deixa de ser uma revolução (não é pouca coisa a reviravolta operada por uma Colônia que se transforma em Estado-nacional), embora pelo alto, renovando a submissão dos de baixo e antagonizando mais acima o jugo metropolitano de seus pares, dos quais precisam entretanto se dessolidarizar, enquanto "imaginam" confraternizar com os que oprimem. Podemos acrescentar então que o esquema de nosso Autor oferece uma plataforma a partir da qual visualizar esse jogo de báscula entre identidade e desidentificação. "Nossa peregrinação limitada encontrava companheiros de viagem, os quais acabavam por perceber que o companheirismo entre eles não se baseava apenas naquele determinado trecho de peregrinação, mas na fatalidade, que compartilhavam, do nascimento transatlântico. Ainda que tivesse nascido na primeira semana depois da migração do pai, o acidente do nascimento na América destinava-o à subordinação - ainda que, em termos de língua, religião, origem familiar ou maneiras, fosse praticamente indistinguível de uma espanhol nascido na Espanha. Não havia nada a fazer quanto a isso: ele era irremediavelmente um creollo". Em pouco tempo, inoculado o vírus colonial do racismo, era simples fazer a dedução vulgar e conveniente: diferentes dos metropolitanos, eram inferiores e portanto inadequados para os cargos 
superiores ${ }^{\mathbf{1 0}}$. Mas para que essas peregrinações tivessem consequências decisivas, ou seja, para que suas extensões territoriais pudessem ser imaginadas como nações, era preciso que outros personagens entrassem em cena. São basicamente dois, no roteiro de Benedict Anderson. Comecemos pela imprensa.

Os primeiros jornais sul-americanos apareceram praticamente como prolongamentos do mercado. "Os mais antigos jornais continham - ao lado das notícias sobre a metrópole - notícias comerciais (partidos e chegadas de navios, quais os preços, para que mercadorias, em que postos), bem como ordenações políticas coloniais, casamentos dos ricos, e assim por diante. Em outras palavras, o que colocava lado a lado na mesma página, este casamento com aquele navio, este preço com aquele bispo, era a própria estrutura da administração e do sistema de mercadorias coloniais. Desse modo, o jornal de Caracas, de maneira muito natural e até mesmo apolítica, criava uma comunidade imaginada entre uma determinada congre-

10. Abstenho-me por enquanto de qualquer extrapolação brasileira. Seja como for quanto à forma pela qual venham a se apresentar as jornadas brasileiras da imaginação, é possível prever no entanto - e por isso prevenir a confusão desde já - que com a surpreendente interiorização da metrópole na colônia com a transferência da família real em 1808, tangida pelas tropas do Marechal Junot, o quadro de nossas peregrinações deve ter sido afetado em profundidade. Além do mais seria preciso lembrar desde já que em virtude da escassez de recursos da metrópole diminuta ante a amplitude de seus domínios coloniais, a incorporação em sua burocracia de elementos locais treinados em Coimbra terá assumido uma outra feição, como prova - para dar um exemplo extremo - a carreira singular de um José Bonifácio (para não falar na atuação dos deputados "brasileiros" nas Cortes de Lisboa em 21-22), percorrendo a Europa a serviço do governo português, sonhando em construir na América um grande império e por fim apadrinhando a Independência, na condição de fiador da continuidade dinástica e traço de união (quem diria) entre a colônia e novo país, por assim dizer vinculados por uma mesma e simbólica peregrinação. Cf. José Murilo de Carvalho Pontos e Bordados, Belo Horizonte: UFMG, 1998, pp.235-236. Não por acaso o artigo em que me apoiei se intitula "Brasil: Nações imaginadas". Voltaremos, é claro. gação de companheiros, à qual pertenciam esses navios, noivas, bispos e preços. Naturalmente, só se podia esperar que com o correr do tempo, aí entrassem elementos políticos"(p.73). Vimos há pouco a burocracia colonial lavrando o território, conferindo-lhe um "sentido" graças aos destinos cruzados dos funcionários peregrinos. Essa mesma consciência de conexão emerge reforçada na justaposição, visualizável na página de um jornal, de elementos heteróclitos a um tempo nivelados pela forma mercantil (noivas e bispos são também artigos, aliás preciosos, do comércio colonial) e realçados pela significação inédita da circunstância que os congrega, como se por um momento a lenda do doux commerce, matriz da sociabilidade civilizatória, brilhasse nos confins do Antigo Sistema Colonial, em crise mas só aos olhos das imaginações proprietárias, obviamente - a imaginação da comunidade dos consumidores de uma economia de massa ainda estava no limbo. O decisivo nesta primeira invenção da nação - artefato cuja fantasia plasmadora não poderia estar mais materialmente ancorada, como estamos vendo, se nosso Autor tem razão - é o "mundo imaginado de leitores", a congregação dos companheiros proprietários dos navios, bispos, noivas e os demais gêneros coloniais que pautaram o "sentido" daquela fabricação, leitores de jornal, no caso, mundo no qual se refratam idealmente os eventos idênticos "lidos" por assim dizer ao mesmo tempo, simultaneidade tanto mais efetiva por ser imaginada. Essas temporalidades paralelas e simultâneas têm a ver, é claro, com o tipo de consumo exigido pelo jornal - sabemos que suas edições serão lidas muito provavelmente entre tal hora e tal hora, apenas neste dia e não em tal outro. Qual a vinculação entre as notícias da primeira página de um jornal? Para nosso Autor, ela é da ordem do imaginário, mas a fantasia, 
no caso, também é exata. Não é o mero capricho que liga os eventos justapostos na página impressa, contudo "é óbvio que a maioria destes aconteceu independentemente, sem que seus autores tivessem consciência uns dos outros, ou de que os outros estavam fazendo. A arbitrariedade de sua inclusão e justaposição demonstra que a vinculação entre eles é imaginada”.(p.42) Ou melhor, precisa ser imaginada, pode ser imaginada. Essa vinculação imaginada provém de duas fontes - sempre segundo nosso Autor, inútil lembrar. "A primeira é simplesmente coincidência no calendário. A data no alto do jornal, a marca mais peculiar que ele apresenta, fornece a conexão essencial - a marcação regular da passagem do tempo. Dentro daquele tempo, o mundo caminha decididamente para a frente". O sinal disso: se uma determinada localidade, depois de ser notícia durante dias seguidos, subitamente desaparece por meses a fio, nem por um momento os leitores pensarão que ela simplesmente desapareceu, mas que em algum lugar fora das páginas impressas continua a existir e por isso aguardam sua reaparição naquelas mesmas páginas. Tal como o leitor aficionado imagina um personagem de romance. Pois esse é o outro dos achados preciosos de Benedict Anderson. Não sei se me explico bem: obviamente não se está querendo dizer que redescobriu sozinho o sistema de vasos comunicantes que asseguram faz tempo a circulação entre a moderna prosa de ficção e as técnicas literárias do jornalismo, pois a rigor este último é contemporâneo da narrativa realista europeia, e pelo menos se entrecruzam desde o setecentos inglês. Mas não diria que é tão trivial assim ressaltar o caráter ficcional da convenção literária fundamental do jornal, e mais particularmente seu feitio de romance. Costuma-se, ao contrário, quando não se contrapõe frontalmente o achatamento do fato à profundidade multidimensional da ficção, invocar a paralização da imaginação do leitor pelos estereótipos da apresentação jornalística do mundo. Walter Benjamin, como se sabe, deu forma canônica à essa demonstração do déficit crônico de que padece a notícia de jornal, sobretudo quando confrontada, como ele mesmo fez, à figura seminal do Narrador, de tal sorte que o jornal comparece no limiar da modernidade como um sintoma da crescente degradação da experiência - enquanto capacidade de articular e comunicar conteúdos no longo curso de um aprendizado histórico: a seu ver, já a própria composição em mosaico de uma página de jornal, cujo ponto de honra é a ausência de correlação entre as informações, é a primeira e intransponível barreira entre os acontecimentos e a experiência do leitor, apressando um pouco mais o seu lento definhar.

Ora, curiosamente, no que esbarrou Benedict Anderson senão na força estruturante da justaposição de uma notícia ao lado da outra - este navio, este bispo, esta noiva, estes preços -, uma composição que, longe de nivelar e compartimentar, parece articular - no sentido em que a narração articula e põe em perspectiva - uma experiência coletiva de comunicação, em que o nexo pode muito bem ser duas formas sociais modernas, a mercadoria e a burocracia, ao contrário exatamente do que sugere a imagem retroativa do Narrador em Benjamin. Um parêntesis: tampouco estou sugerindo, como farão logo mais, e a seu tempo discutiremos, os desconstrucionistas pós-coloniais, que nosso Autor simplesmente antecipou o trocadilho metafísico que torna a Nação mero "efeito de real" de uma Narração originária"11. Um cotejo esclarecedor: para

11. Cf. p.ex. Homi K. Bhabha (org.), Nation and Narration, Londres: Routledge, 1990. 
Benjamin, sendo os jornais reproduzidos numa multidão de exemplares, não fornecem aos seus leitores histórias que possas em seguida ser contadas aos outros, quebrando as cadeias narrativas formadoras da tradição. Pois essa mesma multidão - de jornais e leitores - muda de figura quando passamos - sempre com nosso Autor - à segunda fonte de vinculação imaginada entre as notícias de um jornal: o rito coletivo que vem a ser o consumo quase que exatamente simultâneo do jornal-como-ficção. "A significação dessa cerimônia de massa - Hegel observava que os jornais são, para o homem moderno, um substituto das preces matinais - é paradoxal. Ela se desenrola em silenciosa intimidade, bem no fundo da cabeça”. Em feitio de oração, portanto. Todavia, mesmo arriscando o mal-entendido, e antecipando imprudentemente o segundo movimento do argumento geral deste capítulo de abertura, o ato solitário dessas leitura concomitantes apresenta um outro feitio, nada mais nada menos do que uma imagem do pensamento, mais exatamente, dessa autorregulação silenciosa que se chama "pensamento", como se pode ler (à revelia) numa outra fórmula de um outro autor, e que a seu tempo trataremos de recuperar.

Voltando: uma alheamento paradoxal, pois reforça o senso de realidade. Com efeito, "cada um dos comungantes está bem cônscio de que a cerimonia que executa está sendo replicada, simultaneamente, por milhares de outros, de cuja existência está seguro, embora não possua a menor ideia sobre a identidade de cada um. Mais ainda, essa cerimônia é repetida em intervalos de um dia, ao correr do calendário”. Interrompo a citação para indagar se não se poderia tomar este ritual como uma das tantas ilustrações possíveis da metáfora de Renan, sua definição da nação como um plebiscito diário; nosso Autor diria que nem tanto, devido à sua conotação deliberativa explícita e que a geração da vontade impessoal - se é disso que se trata, no caso da conversão da desigualdade de classe real em igualdade abstrata de cidadãos, por intermédio dos mecanismos convencionais de representação política - se encontra, pelo contrário, sobretudo nas "regularidades diárias da vida da imaginação". Voltemos então a um de seus mecanismos mais eficientes, pelo menos no âmbito do primeiro ciclo da invenção da nação: se alguém invocasse pela enésima vez, o caráter burguês dessa fabricação, Benedict Anderson não diria que não, desde que acompanhada tal evocação, pela seguinte ressalva: não sendo possível conceber uma burguesia analfabeta, será permitido ver nesta classe discutidora e leitora de jornais, a única durante um bom período, a inventora patenteada da marca nacional, desde que se entenda a nação como produto da imaginação de uma "coalizão de leitores", e precisamente uma coalizão de classe, a rigor a primeira classe social a "consumar solidariedades numa base essencialmente imaginada". Retomando a citação interrompida: "o leitor de jornal, vendo réplicas exatas do seu jornal sendo consumidas por seus vizinhos de transporte coletivo, no salão de barbeiro, em casa, sente-se permanentemente tranquilo a respeito, diante do fato que o mundo imaginado está visivelmente enraizado na vida quotidiana"(p.44). Uma encarnação "nacional" do sensus communis dos filósofos? Afinal, tudo parece se passar como se uma sensação muito forte de realidade brotasse dessa espécie de sexto sentido compartilhado durante a cerimônia coletiva de leitura de um jornal, como se esse senso comunitário - para voltar a falar como os filósofos - por assim dizer ajustasse a autoregulação silenciosa no fundo da cabeça de cada leitor ao modo (e não ao conteúdo) de representação 
de qualquer outro "imaginando" a realidade a partir do que está impresso no mesmo jornal. Acresce que essa presença muito real de um mundo comum está calçada num pacto ficcional. Mas como vimos, não se trata de qualquer ficção, mas precisamente daquela capaz de deslizar "silenciosa e continuamente para dentro da realidade, criando aquela notável segurança de comunidade anônima que é a marca garantida das nações modernas".

Aqui o outro achado de Benedict Anderson - banalizado até o grotesco teorizante pelos ideólogos autodesignados pós-coloniais -, a ligeira inflexão num velho tópico de história literária, tão velho e datado quanto o Romantismo e o Nacionalismo literários: como e porque uma estrutura básica de se imaginar, surgida na Europa no século XVIII, também forneceu, tal como o seu contemporâneo, o jornal, os recursos técnicos para reapresentar a espécie de comunidade imaginada que é a nação ou, para emendar no achado anteriormente referido - por iluminar a invenção precoce da forma nação na periferia -, para que as extensões territoriais percorridas pelos funcionários peregrinos começassem a fazer "sentido", para além do mercado e da administração. Foi o caso do romance, como era de se prever - numa palavra, o romance como um instrumento privilegiado de descoberta do país e de interpretação social, como Antonio Candido caracterizou o aparecimento da ficção entre nós, quando a ex-colônia recentemente emancipada também estava carecida não só de se tornar politicamente viável mas igualmente "emocionalmente plausível". Como se viu, esse o ponto de nosso Autor, e se me antecipei invocando Antonio Candido foi para sublinhar melhor a novidade do esquema que estamos apenas recapitulando, pois a novidade não reside apenas no registro da vocação histórica e sociológica do romantismo literário e portanto, atender à demanda "nacional" de criar a expressão nova de um país novo; para além da cor local e seus derivados, vem ao caso agora pesquisar nos elementos da forma romance as condições de possibilidade da representação daquela comunidade especial que justamente carece de tal forma para se constituir e se ver como realidade - em suma, uma excelente explicação histórico-estrutural do por quê do papel privilegiado de instrumento de "descoberta" do país desempenhado pelo romance. ${ }^{12}$

12. Faltou lembrar um último traço "instituinte" - para falar como os filósofos franceses do imaginário - da imprensa colonial, e que continuará ativa na produção da realidade imaginada da futura nacionalidade. Voltemos ao jornal de Caracas e à comunidade de interesses locais a qual pertenciam navios, noivas, bispos, preços. Segundo Benedict Anderson, "um creollo colonial, de tivesse oportunidade, poderia ler um jornal de Madri (o qual, porém, não diria nada sobre o seu mundo), mas muitos funcionários peninsulares, morando na mesma rua, não leriam o que se produzia em Caracas se pudessem deixar de fazê-lo" (p.73). Duas consequências: primeiro, essa assimetria reforça e confirma os mecanismos de preterição que vimos atuando nas jornadas truncadas dos funcionários confinados ao Novo Mundo, segregando ainda mais o mundo imaginado dos nativos. Consumada a separação, e tendo em mente a extração genuinamente europeia da nova camada dirigente, encarregada de montar e gerir um estado reconhecido internacionalmente e inventar uma nação política e emocionalmente viável, seria o caso de dizer que uma tal assimetria quais as notícias que me concernem? Noivas e bispos da praça local ou os ecos da civilização metropolitana em progresso? - seria interiorizada como alternância permanente pelo mesmo personagem "ocupante". Em segundo lugar, o caráter inequivocamente provinciano daqueles jornais. E aqui o provincianismo não é um déficit, pelo contrário, com o tempo se revelará uma vantagem imaginária estratégica, além de filtrar o pitoresco associado mais tarde à obsessão com a cor local. Outra consequência: esse enraizamento provinciano da imaginação é replicável, multiplicando-se as províncias na sua pluralidade, por assim dizer viabilizando em termos "nacionais" a futura fragmentação da América Espanhola. "Os periódicos hispano-americanos que se desenvolveram no final do século XVIII eram compostos com plena consciência da existência de provincianos em mundos paralelos ao seu. Os leitores de jornal da cidade do México, de Buenos Aires e de Bogotá, ainda que não lessem os jornais uns dos outros, estavam no entanto perfeitamente conscientes de sua existência”. Outra contribuição das coalizões provincianas de leitores de jornal para atenuar na fantasia nacional o fato bruto da ancoragem da nacionalidade no contingenciamento da força de trabalho compulsório. 
Passemos então à segunda matriz da imaginação nacional. Embora a ressalva não pareça invalidar a hipótese geral, é bom deixar claro que o argumento de Benedict Anderson deriva de considerações sobre a estrutura de romances "à moda antiga". E nem poderia ser de outro modo. Quer ela se apresente nas obras primas do Grande Realismo europeu, ou num romanceco qualquer do período, a Era do Romance e o momento histórico em que transcorreu o auge do processo de Nation making são rigorosamente contemporâneos. ${ }^{13}$ No seu modo de ver, o romance é antes de tudo um instrumento de apresentação de simultaneidades. Eis os seu esquema: "tomemos, para fins de ilustração, um segmento de um enredo simples de romance, no qual um homem A possui uma esposa B e uma amante $\mathrm{C}$ que, por sua vez, tem um namorado D"; a

13. A exceção Machado de Assis (já que estamos antecipando) confirma a regra, quer dizer: os efeitos miméticos produzidos pela prosa machadiana com recursos não-realistas. Essa escolha composicional, todavia, não se deve a mero capricho, ao decalque agrãfinado do humor inglês, como um tempo se supôs, mas ao discernimento do escritor que primeiro atinou que a formação da nacionalidade não se completaria, que o país estava entrando de costas na modernidade burguesa: daí a forte sensação de realidade que até hoje provoca sua ficção, prova de que, "imaginou" em profundidade a "nação" abortada porém estritamente contemporânea do mundo do capital. (Fácil dizer, depois que Roberto Schwarz decifrou o enigma Machado de Assis). Outra exceção confirmadora, Borges. Neste caso, o ciclo ficcional recobre um outro momento da forma nacional, para ser exato algo parido pela transição populista para a industrialização periférica. À luz do retrocesso geral das duas últimas décadas, outra época de construção inter rompida que se encerra. Tal como em Machado, a referência nacional em Borges - habilmente camuflada, como exigia sua composição não-realista - é tanto mais presente quanto a "nação imaginada" é a cifra local de uma sequência mundial catastrófica. Por isso mesmo, o invólucro cosmopolita de um e de outro, Machado e Borges, é mais do que despiste destinado a encalacrar o compatriota intoxicado de fumaça universalista, algo terá a ver com o esforço artístico de captar o alcance transnacional das respectivas malformações nacionais. Nesses termos precisos, seria então o caso de concluir que ambos são autores "globais". Ou épicos modernos, como preferiria dizer Franco Moretti, a propósito deste dois autores "enciclopédicos”, que só por um descuido ainda não integram sua lista de criadores de "textos mundiais". Cf. Franco Moretti, Modern Epic, Londres: Verso, 1996. seguir supõe uma sequência temporal em três movimentos ao longo dos quais transcorrem ações paralelas, de tal sorte que se poderá verificar que, no correr dessa sequência, "A e D jamais se encontram, e podem na verdade não ter sequer conhecimento da existência um do outro, se $\mathrm{C}$ tiver agido inteligentemente. Então, o que é que realmente liga A e B? Duas concepções complementares: primeiro, que eles estão encravados em 'sociedades' (por exemplo, Wessex, Lübeck, Los Angeles). Essas sociedades são entidades sociológicas de uma realidade tão firme e estável que seus membros (A e D) podem até mesmo ser descritos como passando um pelo outro na rua sem jamais se relacionarem e, ainda assim, estarem ligados. Segundo, que A e D estão encravados na mente de leitores oniscientes. Apenas eles percebem os vínculos. Apenas eles observam A telefonando a C, B fazendo compras e D jogando sinuca, tudo ao mesmo tempo. O fato de que todos estes atos são desempenhados no mesmo tempo, medido pelo relógio e pelo calendário, mas por atores que podem passar em grande medida despercebidos uns em relação aos outros, demonstra a novidade deste mundo imaginado evocado pelo escritor na mente de seus leitores"(pp.34-35).

A essa altura devemos recordar o principal traço determinante da definição de Benedict Anderson da nação como uma comunidade política imaginada. Como vimos, a deixa lhe veio da tese inovadora de Gellner: a consciência nacional não resulta do despertar para a vida autoconsciente de uma realidade nacional prévia que jazia adormecida, alienada de si mesma, a espera de uma ressurreição, mas é a inventora de nações onde elas nem existem. A esta primeira indicação do caminho a seguir, veio juntar-se a tradução de uma frase de outro historiador do nacionalismo, Setton-Watson, segundo o qual se pode dizer que 
uma nação existe "quando um número significativo de pessoas de uma comunidade considera que constituem uma nação", e se comportam em consequência. Nosso Autor propõe simplesmente que se traduza "considera" por "imagina". Encontra em seguida confirmação de sua intuição num documento clássico do primeiro ciclo longo de formação das nações, a conferência de Renan de 1882, na qual interpreta a "vontade de viver juntos" da forma célebre como resultante política de um ato de imaginar: todo cidadão francês, dizia Renan, para se considerar membro da Nação (com maiúscula desde a Revolução, quando a soberania do povo reunido em Nação destronara a soberania dinástica), precisa é claro ter muita coisa me comum com os demais, mas sobretudo, precisa ter esquecido muitas coisas, como a noite de São Bartolomeu, que não há mais de dez famílias na França que possam apresentar provas de origem franca, etc. Feitas essas preliminares, acrescenta a grande novidade de sua definição, para a qual nem sempre se deu a devida atenção, o acento recaindo sempre no caráter imaginário da "invenção". Trata-se de comunidade imaginada "porque nem mesmo os membros das menores nações jamais conhecerão a maioria de seus compatriotas, nem os encontrarão, nem sequer ouvirão falar deles, embora na mente de cada um esteja viva a imagem de sua comunhão" (grifo meu). A seu tempo veremos esse Outro imaginado reaparecer noutra cena. Completemos a citação: "De fato, todas as comunidades maiores do que as primitivas aldeias de contato face a face (e talvez até mesmo estas) são imaginadas. As comunidades não devem ser distinguidas por sua falsidade/autenticidade, mas pelo estilo em que são imaginadas [será permitido intercalar: a nação e o nacional não são ideias intrinsecamente falsas ou verdadeiras; e mais uma vez: o nacionalismo não é uma ideologia, mas um sistema cultural amplo]. Os aldeões javaneses sempre souberam que estavam ligados a pessoas que jamais haviam visto, mas tais vínculos eram outrora imaginados de maneira particularista - como malhas indefinidamente extensas de parentesco e dependência. Até mais recentemente, a língua javanesa não possuía uma palavra para significar uma abstração "sociedade"” (pp.14-15).

Esta última menção da abstração "sociedade" pede uma breve digressão, sobretudo porque parece estar servindo de contraponto a uma outra abstração, a "comunidade". Ora, talvez seja necessário deixar mais claro que nosso Autor não está reativando o par antitético clássico de Tönnies, que sua comunidade não é uma comunidade de origem e destino, tecida por relações pessoais personalizadas, aquecidas pelo calor do grupo primário, etc., embora não esteja longe das "comunidades emocionais" de Max Weber. Seja como for, o decisivo é que Benedict Anderson em nenhum momento tomou o termo em uma acepção realista. Digamos que por mais variada que seja a conceituação da "realidade" da sociedade, comunidade por sua vez, se nosso Autor tem razão, só pode ser imaginada, sob pena de ser uma fraude toda vez que se apresentar como uma entidade substancial realmente tangível: daí sua condição de artefato - no caso da comunidade nacional imaginada - sugerir a analogia profunda que estamos vendo com uma forma artística - o romance, entendido em sua associação com a estrutura básica do ato de imaginar - na qual a promessa utópica da reconciliação não pode se apresentar jamais como realizada, salvo justamente na aparência estética, que como tal não pretende enganar ninguém, trata-se apenas de uma imagem, e mesmo assim cada vez mais rarefeita: o mesmo para o senso 
comunitário alimentado pela imaginação nacional, para além do fracionamento real de uma sociedade antagônica. Dito isso, a saber, que o essencial de uma comunidade imaginada está na referência ao Outro desconhecido ${ }^{\mathbf{1 4}}$, voltemos à afinidade estrutural entre a comunidade imaginada como nação e o sobrevoo do leitor onisciente de um romance, onisciente à moda antiga claro. E assim é: "um norte americano jamais encontrará, nem mesmo saberá como se chama, mais do que um pequeno número de seus duzentos milhões de compatriotas. Não tem ideias alguma do que estão fazendo, mas está absolutamente seguro de sua atividade constante, anônima e simultânea". A mesma segurança ficcional do leitor de jornal, como se viu, quanto ao enraizamento do Outro, anônimo e imaginado, na vida quotidiana comum, na acepção mais enfática deste último termo.

Reproduzo a seguir os três exemplos comentados por Benedict Anderson, lembrando de saída que todos se referem a situações coloniais, embora em momentos diferentes de conformação da periferia - Filipinas, México e Indonésia, os dois primeiros compostos na língua da metrópole (espanhol), o último em “indonésio”. Repetindo: tais romances não são nacionais pelo assunto de extração local, em que pode estar até explicitamente figurado o antagonismo com o Ocupante (para voltar a falar como Paulo Emílio), mas são tais pelo isomorfismo entre os dois mundos imaginados, aquele evocado pelo escritor na mente dos leitores e o da comunhão de embarcados que nunca se

14. Porém nada mais próximo e semelhante do que o Ninguém sem nome, o ocupante ausente dos túmulos do Soldado Desconhecido, monumentos que floresceram depois da carnificina da Primeira Grande Guerra. "Por mais que esses túmulos estejam vazios de qualquer restos mortais, eles estão, porém, saturados de fantasmagóricas imaginações nacionais”, Ibid., p. 17. verão: "a ideia [ficcional] de um organismo sociológico(sic) que se move pelo calendário do tempo homogêneo e vazio apresenta uma analogia precisa com a ideia de nação, que também é concebida [imaginada] como uma comunidade compacta que se move firmemente através da história (p.35). Em última instância - por assim dizer, no plano dos elementos constitutivos de uma Gestalt - bem pode ser esta a origem do poderoso efeito mimético da referência nacional, que não precisa ser patrioticamente ostensiva para ser tal: a sociedade do romance "à antiga" já se apresenta de saída como sendo nacional - como se poderá verificar no comentário dos três parágrafos de abertura do romance de José Rizal, de 1887, que a seguir transcrevo, e pelo qual não há dúvida que devo Ter sido visto pelos seus contemporâneos como a prova da existência de uma sociedade nacional naquelas longínquas paragens coloniais.

"Basta que se observe que, logo de início, a imagem (inteiramente nova na literatura filipina) de um jantar que é discutido por centenas de pessoas anônimas, que não se conhecem entre si, em diferentes bairros de Manila, num determinado mês de uma determinada década, evoca imediatamente a comunidade imaginada. E na frase 'uma casa na rua Anloague, que ainda pode ser reconhecida...', quem reconhece somos nós-os-leitores-filipinos ${ }^{15}$. A passagem natural dessa casa, do tempo "interior' do romance, para o tempo 'exterior' da vida quotidiana do leitor de Ma-

15. Tal como nós-os-ouvintes-italianos reconhecendo em voz alta de comovida surpresa numa noite na ópera de Milão, pintada no telão de fundo dos Lombardos na Cruzada, do jovem Verdi, a igreja de Santo Ambrósio da sua cidade. Na pré-história do Risorgimento, a comunidade imaginada italiana deve ter sido sobretudo ouvida, qualquer que fosse a convenção melodramática do momento. Basta pensar no coro do Nabuco assobiado, controlado, engrenado nos realejos. Terá contribuído é claro o gênero público a que pertence a ópera. 
nila oferece uma confirmação hipnótica da solidez de uma comunidade singular, abrangendo personagens, autor e leitores, que se movem para diante pelo tempo do calendário. Observe-se também o tom. Embora Rizal não tenha a menor ideia da identidade de cada um de seus leitores, escreve para eles com uma intimidade irônica, como seu relacionamento com eles não fosse nem um pouco problemático"(pp.36-37). Só para antecipar e fixar de antemão a "imaginação" do leitor brasileiro: não conheço ilustração mais viva e precisa da ideia de sistema literário segundo Antonio Candido, com o acréscimo mais do que natural dos "personagens" ao circuito cumulativo, evoluindo no tempo, de obras, autores e público leitor. Numa palavra, o referente do sistema literário - no interior do qual os autores não cessam de "situar" seus protagonistas na "sociedade" e discuti-los com "seu” público -, só pode ser uma comunidade política imaginada, para começo de conversa, é claro.

No segundo exemplo, um romance de 1816, El periquillo sarniento, de Lizardi, fica ainda mais evidente a originalidade do ponto de vista que está servindo de ponto de apoio para a elaboração do nosso próprio argumento - mais ou menos o seguinte, em termos ainda sumários: pelo menos até ontem, só a referência nacional (da imaginação) nos fazia e permitia pensar; e se assim foi, a agenda "que fazer?" segue atrelada à resposta à pergunta: o que nos fará pensar, à medida que avança nossa absorção por um Império geoeconômico pós-nacional? Fim de parêntese. Trata-se de uma sátira da administração colonial do México, porém não são de modo algum os temas evidentes do empenho antimetropolitano que lhe definem o caráter, mais exatamente o vínculo estrutural entre romance enquanto tal e a "imaginação nacional": pois é esta última que vemos "funcionando nas andanças de um herói solitário por uma paisagem sociológica de uma estabilidade que funde o mundo de dentro do romance com o mundo de fora. Esse tour d'horizon picaresco - hospital, prisões, aldeias longínquas, monastérios, índios, negros - não é porém um tour du monde. O horizonte é claramente delimitado: é o do México colonial. Nada nos assegura mais dessa solidez sociológica do que a sucessão de plurais. Pois eles evocam um espaço social cheio de prisões comparáveis, nenhuma delas por si só de qualquer importância singular, mas todas representativas (em sua existência simultânea e distinta) da tirania desta colônia" (p.39).

Finalmente, o romance de um jovem indonésio nacionalista-comunista, publicado em folhetim nos anos vinte deste século, Marco Kartodicromo. Estamos de novo num mundo de plurais, nota Benedict: oficinas, escritórios, carruagens, kampongs e lâmpadas de gás. Como no caso filipino, "nós-os-leitores-indonésios mergulhamos indiretamente num tempo de calendário e numa paisagem familiar; alguns de nós podemos bem ter caminhado por aquelas 'peguentas' estradas de Samarang. Uma vez mais, um herói solitário é sobreposto a uma paisagem social descrita em detalhes cuidadosos e gerais. Mas há também algo de novo: um herói que nunca é chamado pelo nome, mas coerentemente mencionado como nosso jovem. Exatamente o caráter canhestro e a ingenuidade literária do texto confirmam a 'sinceridade' não deliberada desse adjetivo pronominal. Nem Marco, nem seus leitores, têm qualquer dúvida quanto à referência. Se na ficção jocosa e elaborada na Europa dos século XVIII e XIX, o tropo 'nosso herói' simplesmente ressalta um jogo do autor com um leitor (qualquer), o 'nosso jovem' de Marco, não menos pela inovação, significa um jovem que pertence 
ao corpo coletivo dos leitores do Indonésio, e assim, implicitamente, uma embrionária 'comunidade imaginada' indonésia. Observe-se que Marco não sente necessidade de especificar essa comunidade pelo nome: ela já está aí. (Mesmo que os censores coloniais holandeses poliglotas se juntem a seus leitores, eles estão excluídos de participar desse 'nosso', como se pode ver pelo fato de que o ódio do jovem se dirige ‘ao' e não ao 'nosso', sistema social” (p.41). Fechando o círculo, a confirmação da comunidade nacional imaginada pela réplica interna da leitura cuja teoria estamos acompanhando: é que mal iniciado o relato, "nosso jovem" se depara com uma notícia de jornal acerca da morte de um "miserável vagabundo", abandonado à beira de uma estrada; literalmente "o jovem comoveu-se com esse breve relato. Imaginava perfeitamente o sofrimento daquela pobre alma quando jazia moribundo..."Como se queria demonstrar. Para sublinhar a novidade, voltemos ao contraponto armado pela opinião oposta a de Benjamin, que talvez tenha pago um preço alto demais privilegiando a figura arcaica do Narrador, sem dúvida porque lhe interessava arriscar a hipótese de largo fôlego histórico que sugeria entroncar a recepção coletiva da arte de massa à transmissão da experiência pelo relato face a face nas sociedade tradicionais. Assim, quem ouve um relato forma sociedade com o narrador, mesmo quem o lê participa também dessa companhia, ao passo que, na outra ponta da atrofia moderna da experiência, nada mais antissocial do que a individuação burguesa do leitor de romance, nada mais solitário do que o ato de ler um romance, em cujo encasulamento desaparece de vez a antiga comunidade dos que escutam. No afã de rastrear as derradeiras promessas desta última na Era da Reprodução Técnica, Benjamin deixou escapar - se Benedict Ander- son esbarrou numa pista verdadeira - um traço notável do capitalismo editorial - sempre segundo nosso Autor -, o fato de que o livro foi a primeira mercadoria industrial produzida em série no estilo moderno e que assim sendo, “o jornal não passa de uma forma extrema do livro, um livro vendido em escala imensa, porém de popularidade efêmera. Poderia dizer-se que são best-sellers por um só dia” (p.43). Daí a conclusão oposta -, o paradoxo do leitor solitário, que se reproduz e resolve analogamente na cerimônia de massa do consumo diário do jornal e no isolamento absoluto em que avidamente o leitor se apropria do sentido de um romance: como vimos, e não custa repetir para melhor frisar a inversão da perspectiva, a leitura de um romance se desenrola bem no fundo da cabeça, "em silenciosa intimidade”, e no entanto, cada leitor não seria senão a comunidade de leitores "solitários" que por assim dizer leem por sobre seus ombros.

Na opinião de Franco Moretti, para encerrar esta primeira aproximação, que também deve ter ficado muito impressionado com as páginas de Benedict Anderson acerca da afinidade estrutural entre a forma de se imaginar a sociedade num romance e a descoberta de algo como uma imaginação nacional, uma página precisa ser virada: uma vez estabelecida, explorada e revirada (mas a cada caso sempre uma surpresa) a conjunção entre o romance e o curso do mundo capitalista, teria chegado a hora (por que?) de estudar a fundo as relações entre o romance e o Estado-nação, mais exatamente a realidade geopolítica da forma-nação no âmbito do capitalismo enquanto sistema mundial de acumulação e governo - para tornar mais explícitos os apoios do Autor ${ }^{\mathbf{1 6}}$. A seu ver - na pista é claro de

16. Cf. Franco Moretti, Atlas of the European Novel 1800-1900, Londres: 
Benedict Anderson - sempre se pode abarcar com o olhar o sistema "a corte e a cidade", e mediante uma metonímia apropriada, até mesmo o universo, mas um Estado Nacional, formação de resto recente? Somente a forma simbólica romance pode representá-lo, quase que num processo de invenção recíproca. Ato contínuo, Moretti passa à verificação sistemática da "imaginação nacional” em seus primórdios, estudando a "invenção" da Inglaterra nos romances de Jane Austen. E invenção igualmente na acepção nada óbvia de que para os seus contemporâneos o alcance especial de seus romances era algo de escassa evidência, de sorte que foi preciso um delicado jogo de andaimes para que tal espaço fosse aos poucos fazendo sentido - e um "sentido" que se apresentaria enfim como "nacional". A seguir, uma reminiscência de achados conhecidos nossos. Por exemplo, um ou dois mapas - entre vários - representando os lugares em que principiam e terminam os enredos, em geral a residência da heroína, para os primeiros, e a do futuro marido, para os segundos, e de tal modo conectados que as mulheres passam a se sentir seguras, "em casa", numa palavra, quando se deslocam nessas viagens domésticas, que logo vão assumindo proporções "nacionais". Nada mais nada menos do que mapas de verdadeiras "peregrinações" que vêm a ser tais "jornadas de sedução", entrelaçando a gentry provinciana a algo como uma elite nacional num mesmo território demarcado por um mercado nacional de casamentos; mapas portanto de

Verso, 1998, pp. 16-17. Ainda que sobriamente, Moretti se apoia na teoria dos sistemas mundiais (Wallerstein, Chase-Dunn, T. Hopkins, etc.), e também no esquema de Charles Tilly (p.ex., Coerção, Capital e estados Europeus, Edusp. 1996), no que se refere às trajetórias de passagem das lealdades locais para as "nacionais"- um sistema inédito de integrações e rejeições, mais abstrato e enigmático, e que assim carecia de uma nova forma simbólica para ser entendido. distâncias médias e viagens cujos custos sentimentais se pode avaliar, literalmente uma rede de intrigas "casando" pessoas de diferentes localidades ${ }^{17}$.

Até aqui a resenha, como combinado. E pelo caminho, algumas insinuações. É hora de desenvolvê-las, invertendo o raciocínio. Pois vimos até agora mediante quais práticas não planejadas - das peregrinações coloniais ao senso comunitário do ato de ler - tornou-se social e historicamente possível a representação de uma comunidade imaginada, numa palavra, tornou-se possível "pensar" a

17. Uma citação de Raymond Williams também traz as impressões digitais deixadas pela leitura de Benedict Anderson no Atlas do nosso Autor. "Em Jane Austen, os vizinhos não são as pessoas que moram mais perto; são as pessoas que mesmo a uma distância um pouco maior e que, em termos de reconhecimento social, podem ser visitadas. O que ela vê em todo o campo é uma rede de casas e famílias de proprietários, e nos buracos dessa rede fechada situa-se a maioria das pessoas concretas, que simplesmente não são vistas. Estar face a face nesse mundo já implica pertencer a uma determinada classe (...) O campo (...) só é tema social na medida em que está relacionado às casas que constituem os nódulos verdadeiros."(O Campo e a Cidade na História e na Literatura, trad. Paulo Henrique Britto, São Paulo: Cia. das Letras, 1989, pp.229-230.) Como o texto comparece sem comentários na legenda de um mapa (cf.p.12), acrescento duas observações. A primeira, obviamente, chamando a atenção para o caráter de "peregrinação" da constante troca de visitas entre as sedes das propriedades rurais, "rotas" com um centro metropolitano, via de regra ausente mesmo sendo o imã real. A segunda classe delas, e além do mais entre proprietários rurais desfrutando de um esplêndido isolamento, torna invisível o restante da população real, de fato subalterna - os compatriotas que em princípio a imaginação nacional deveria abarcar. Aqui o inesperado entrecruzamento a sublinhar: é que para Raymond Williams, pelo menos na sua estreia burguesa mais elaborada, os romances, em princípio, lidam com "comunidades cognoscíveis", faz parte de seu método mostrar pessoas e relacionamentos entre elas de modo essencialmente cognoscíveis e comunicáveis. Assim, nos romances de Jane Austen "os relacionamentos são claramente do tipo face a face; as crises, físicas e espirituais, se expressam justamente nestes termos: olhares, gestos, esgares, confrontos; e por trás de tudo isso, o tempo todo, o romancista está observando". À medida que a experiência urbana for avançando, o romance recorrerá cada vez mais à imaginação divinatória do movimento subterrâneo das classes, como será o caso de Dickens, para começar. Moretti no entanto replicará, com razão, que essas duas Inglaterras, igualmente "imaginadas", se encontram em Jane Austen, cujo objetivo, além do mais, consiste em converter em story essa divisão nacional, de uma comunidade que só pode ser imaginada por estar assim assimetricamente implicada numa mesma contradança. 
nação. Digamos que se trata agora de tirar as aspas e encarar o caminho oposto: quem sabe não é essa comunidade de "outros" imaginados na forma de uma "nação" (que já sabemos não ter uma realidade substantiva) que simplesmente - ou melhor modernamente - torna possível essa autorregulação silenciosa na cabeça de cada um que chamamos pensamento. Enfim, uma comunidade política imaginada e implicitamente imaginada como soberana e limitada, pode muito bem oferecer uma imagem fiel e conforme do ato de refletir.

\section{Comunidades reflexionantes}

Se Benedict Anderson está certo, o menos que se pode dizer é que deu outra vida à sempre alegada origem burguesa as ideia nacional - à favor ou contra, à direita ou à esquerda, raramente tal gênese foi contestada, a ponto das opiniões em contrário parecerem aberrantes, e novamente tanto à esquerda quanto à direita. Afinal, o próprio Sies, um ano antes da Revolução, não proclamara que o Terceiro-Estado era uma Nação completa? Mesmo a concepção dita romântica - que se costuma contrapor à sua acepção contratualista e republicana - também é fruto da fantasia burguesa, no caso uma fabulação compensatória de intelectuais alemães sufocados pelo arbítrio e prepotência dos representantes locais do Antigo Regime - ao seu modo, um regime de lealdades dinásticas "multinacionais". Em suma, a "imaginação nacional" com a qual acabamos de travar conhecimento, nasceu da ruminação de "peregrinos" e leitores recrutados entre as novas classes proprietárias - e proprietários coloniais, no que concerne nossos pais fundadores. Repetindo por um outro ângulo o argumento: ao contrário das aristocracias tradicionais, cuja solidariedade de classe era produto do parentesco, da dependência e lealdade pessoais - "nobres 'franceses' podiam ajudar reis 'ingleses' contra monarcas 'franceses"' -, a coesão de classe da burguesia, estando fundada numa abstração como o processo de valorização do capital, precisou ser tanto mais imaginada - nos termos em que se viu - quanto não era nem um pouco concreta, levando em conta o parâmetro anterior. "Um dono de fábrica em Lille só estava ligado a um dono de fábrica de Lyon por reverberação. Eles não tinham uma razão necessária para conhecer a existência um do outro; tipicamente, não se casavam com a filha do outro, nem herdavam as propriedades um do outro. Mas chegavam a visualizar de um modo geral a existência de milhares e milhares de outros como eles por intermédio da língua impressa. Pois é difícil acreditar numa burguesia analfabeta. Assim, em termos de história mundial, as burguesias foram as primeiras classes a consumar solidariedades numa base essencialmente imaginada"(Ibid., pp. 87-88). E assim sendo, quer dizer, imaginando-se uma nação completa, a burguesia, no pleno exercício de sua faculdade, "visualizar" semelhanças, podia se apresentar como uma verdadeira anfitriã, oferecendo de boa fé o "espetáculo de 'convidar a entrar' (ainda que apenas até a sopa) seus compatriotas oprimidos"(p.93). Como vimos, essa lógica da peruanização segundo San Martin, que por ser imaginária possuía o condão inestimável de tornar "imaginável”, por exemplo, a perpetuação da escravidão... Nacionalismo a convite, em suma.

Repisado o argumento geral - a nação é uma comunidade política imaginada porque na mente de cada um 
dos compatriotas desconhecidos reverbera a imagem de uma liga filistina -, verifiquemos, agora por nossa conta, se algo dessa consciência de conexão, a cujos suportes materiais fomos apresentados, e justamente enquanto meios que tornaram possível a um número cada vez maior de pessoas "pensarem sobre si mesmas e se relacionarem com outras", verifiquemos enfim se algo dessa constelação não transparece, à sua revelia é claro, no modo pelo qual Hannah Arendt sempre concebeu a irredutível originalidade do pensamento político. Semelhanças de família tanto mais surpreendentes quanto jamais lhe ocorreria evocar a esse propósito - et pour cause - algo sequer próximo da ideia moderna de nação - ainda que aliviada de sua carga emocional jacobina, para não falar no êxtase intelectual dos românticos -, sobretudo porque tenderia a concordar com a opinião segundo a qual pode muito bem se concentrar toda a patologia da modernidade, sempre que a importância dos indivíduos descartados pelo curso do mundo se defronta com o poder anônimo de dominação absoluta.

Transcrevo a seguir por extenso os dois parágrafos em que Hannah Arendt se explica acerca do que considera ser a natureza específica do pensamento político, seu caráter "representativo" e "discursivo". Por extenso, mas não na íntegra: o leitor familiarizado sentirá falta de uma referência que preferi omitir para não enredar ainda mais a trama de analogias, embora esteja exatamente ali a fonte "filosófica" a ser explorada, quando se tem em mente a afinidade sugerida entre comunidade imaginada nacional e a forma mesma do pensamento.

“O pensamento político é representativo. Formo uma opinião quando considero uma questão de vários pontos de vista, fazendo presentes as opiniões dos ausentes, isto é, representando-os. Esse processo de representação não adota cegamente as opiniões efetivas dos que estão em outro lugar e que olham, portanto, o mundo a partir de uma perspectiva diferente; não se trata de empatia como se eu tentasse ser ou sentir como outros, nem de somar-me a uma maioria, mas de ser e pensar com minha própria identidade, onde de fato não estou. Quanto mais numerosos os pontos de vista que tenho presentes em meu espírito, no momento em que pondero uma questão, e quanto melhor posso imaginar de que forma eu sentiria e pensaria se estivesse no lugar desse outros, tanto mais forte será minha capacidade de pensamento representativo e tanto mais válidas minhas conclusões finais - minha opinião. O próprio processo de formação da opinião é determinado por aqueles em cujo lugar alguém pensa e usa a sua própria mente, e a única condição para esse exercício de imaginação é o desinteresse, a libertação com relação a nossos interesses privados. Portanto, mesmo se evito toda companhia ou se permaneço completamente isolado ao formar uma opinião, não estou, simplesmente, junto a mim mesmo na solidão do pensamento filosófico; permaneço neste mundo de interdependência mútua, no qual posso tornar-me o representante de todos os demais. Sem dúvida, posso me recusar a fazê-lo, formando uma opinião que só leve em conta os meus próprios interesses, ou os interesses do grupo ao qual pertenço; na verdade, nada é mais comum, mesmo entre pessoas altamente refinadas, do que esta obstinação cega que se torna manifes- 
ta na falta de imaginação e na incapacidade de julgar. Nenhuma opinião é evidente por si mesma. Em questões de opinião, mas não nas relativas à verdade, nosso pensamento é verdadeiramente discursivo, deslocando-se, por assim dizer, de um ponto para o outro, de uma parte do mundo para a outra, passando por todos os pontos de vista antagônicos, até ascender, finalmente, destas particularidades, a uma generalidade imparcial". ${ }^{18}$

Sem forçar muito a nota, podemos dizer que estamos em casa. Em plena comunidade política portanto, cuja existência estaria ameaçada caso definhasse essa capacidade de se imaginar a si mesmo como um Outro, em nome do qual só então se pode falar, na exata medida em que os demais ausentes e anônimos, porém visados em imaginação, executam "em pensamento" essa mesma permuta de posições. Tal como os nossos leitores de romances e jornais, lendo na companhia ficcional uns dos outros, nos termos de agora, "representando-se" uns aos outros. A novidade nesse novo passo vem da observação de que um tal exercício da imaginação formadora das comunidades políticas se confunde com o ato mesmo de pensar, se é que não vem a ser sua própria condição de possibilidade. Desde que não se confunda pensamento e conhecimento, por outro lado inseparáveis. Ao modo é claro em que os distinguiu a própria Hannah Arendt, conforme lhe sugeria uma certa tradição filosófica, que a seu ver remonta à experiência socrática do pensamento, mais exatamente à res-

18. Hannah Arendt, "Verdade e Política", in Entre o Passado e o Futuro, São Paulo, Perspectiva, 1972, pp.299-300. Tradução ligeiramente modificada, logo se verá por quê. posta socrática à pergunta “o que nos faz pensar?”, à qual Platão logo mais daria uma resposta "profissional"- se por "filosofia profissional" entendermos, como faz a Autora, a disciplina mental, e doutrinária, que resulta da assimilação do pensamento ao conhecimento -, sepultando assim, pelo menos até o limiar da modernidade, aquela tradição desviante. ${ }^{19}$

A ressalva vem a propósito de um cochilo de Habermas - para não falar em "erro categorial" -, ao citar por extenso o mesmo trecho de Hannah Arendt, no fecho do artigo em que, para não fugir à regra, denuncia a dimensão helenizante, e portanto inaproveitável, de sua teoria da gênese comunicativa do poder político ${ }^{20}$. A objeção é corrente, mas não deixa de ser intrigante da parte de um autor alvo das mesma restrições no que toca ao caráter socrático - dialógico de sua concepção da prática discursiva geradora de consenso: tal como na polis de Hannah Aren$\mathrm{dt}$, os cidadãos habermasianos que entram em cena no mundo organizado pelo capitalismo também conversam entre si para agir em função de uma vontade deliberativa comum. Mas não é esta afinidade que nos interessa agora, mas uma outra, ao que parece tão pouco visível que o próprio Habermas não se deu conta.

Não se deu conta, para começar, de que Hannah Aren$\mathrm{dt}$, na passagem em questão, não estava empregando a noção de "opinião" em sua acepção tradicional, ou melhor,

19. Cf. Hannah Arendt, A vida do Espírito, Rio de Janeiro, Relume Dumará/ UFRJ, 1991, I3. Ver ainda o artigo de Gérard Lebrun, "Hannah Arendt: um testamento socrático”, in Passeios ao Léu, São Paulo: Brasiliense, 1983.

20. Cf. "O conceito de poder em Hannah Arendt", in Habermas, coletânea organizada por Barbara Freitag e Sérgio Paulo Rouanet, São Paulo: Ática, 1980. Aliás me vali da tradução pelos organizadores do trecho citado de Hannah Arendt. 
moderna, em cujo horizonte reemerge confinada ao âmbito subjetivo das avaliações irrecorríveis, nem verdadeiras nem falsas, ao contrário das proposições objetivas suscetíveis de validação. Mesmo assim para Habermas, Hannah Arendt continuaria tributária dessa disjunção moderna porém convencional entre conhecimento e opinião valorativa, o que a teria impedido de compreender o acordo sobre questões práticas - de que afinal trata a passagem na berlinda - como um processo de formação racional da vontade: e no entanto, mais uma vez, não é outro o processo descrito por Hannah Arendt, segundo ela o processo mesmo do pensamento, no caso político, segundo Habermas, uma certa capacidade de generalização de pontos de vista normativos. O mais curioso é que ambos estão igualmente empenhados em anular o divórcio moderno entre teoria e prática, juízo de fato e juízo de valor, e para tanto não hesitam em evocar a integridade grega da vida reta contra a moderna divisão social do trabalho entre a positividade dos estados-de-coisa e o existencialismo das decisões inapeláveis. Tal evocação obviamente nunca foi literal. Ambos estão à cata de uma descompartimentação que recomponha a unidade perdida porém nos termos da cisão contemporânea irrevogável entre as esferas autônomas da modernização social e cultural: o cognitivo-instrumental, o prático-moral e o estético-expressivo - como Habermas traduziu a separação weberiana entre questões de conhecimento, questões de justiça e questões de gosto, cada um destes âmbitos comandados por lógicas específicas de validação. Logo veremos como Hannah Arendt rejuntou as duas últimas reativando a distinção socrática entre conhecimento e pensamento - por isso poderá dizer que em questões de opinião pensamos discursivamente, sempre em movimento de um ponto de vista para outro, até a anulação do arbítrio meramente opinativo. Quanto a Habermas, sabemos que sua guinada linguística consistiu basicamente em transpor para o domínio em princípio monológico do discurso teórico - precedido é claro pela virada pragmática da tradição anglo-americana, de Pierce ao segundo Wittgenstein -, a estruturação dialógica da problematização normativa, e no caminho de volta, injetar nos efêmeros consensos práticos a dimensão veritativa do primeiro âmbito. Numa palavra, reassimilando "profissionalmente" conhecimento e pensamento, ainda que sobre o suporte mais intangível e fluído da linguagem.

Assim sendo, como ficamos? Segundo Gérard Lebrun, no afã de escapar ao vazio de sentido em que se converteu a moderna sociedade industrial, e suplantar a expressão ideológica dessa desertificação que vem a ser o abismo positivista entre valor e valor de verdade, ambos acabaram ressuscitando não o mundo luminoso da polis, mas o resumo contraditório desse mesmo desencanto moderno, esse equívoco chamado Razão Prática, híbrido duvidoso de enunciados pseudoteóricos e postulados práticos. Contaminação inquietante da teoria pelo interesse prático em Habermas; origem socrática do imperativo categórico em Hannah Arendt: Sócrates pensava, ou melhor, conversava consigo mesmo para não se contradizer caso abrisse uma exceção para os seus atos ${ }^{21}$. No limite não direi que não seja assim. Mas não deixa de ter sua graça ver o autor de uma obra clássica sobre a Terceira Crítica kantiana cego para a presença de seu assunto num e noutro personagem de nosso roteiro de agora: o termo médio capaz de assegurar o vínculo interno entre as esferas que a alienação mo-

21. Cf. Gérard Lebrun, no mesmo livro citado acima, além do artigo sobre Hannah Arendt, "Razão positivista e razão prática". 
derna tornou incomunicáveis encontra-se precisamente na Crítica da Faculdade de Julgar e atende pelo nome de Reflexão - peça capital do assim chamado Discurso Filosófico da Modernidade. A diferença é que Hannah Arendt sabe disso e glosa sua inspiração com pleno conhecimento de causa. Quanto a Habermas, caso se desse conta da presença desse sócio secreto não poderia admiti-lo, sem reconhecer outro ponto cego em seu projeto - daí não ter visto na "opinião" segundo Hannah Arendt, ao contrário da mera visada idiossincrática, o apelo paradoxal do juízo reflexionante ao entendimento argumentado em meio à disparidade das convicções "sem conceito", como diria Kant.

Até onde posso saber, W.G. Runciman, numa remota resenha da tradução inglesa da Teoria da Ação Comunicativa ${ }^{22}$, foi o primeiro não só a assinalar o "erro categorial" cometido por Habermas - àquela altura uma objeção corrente à sua teoria consensual da verdade - mas a observar que a crença habermasiana num padrão de racionalidade tão obrigatório quanto os critérios da evidência científica, porém desta vez entranhado na pretensão de validade de cada ato de fala, era de fato o equivalente, não de uma visão moral do mundo calcada na restauração da Razão Prática, mas da descoberta kantiana da interpelação universal que moveria o menor juízo estético, acrescido é claro do "erro categorial" que Kant cuidadosamente evitou, a confusão entre o apelo à universalidade inerente ao juízo de gosto ainda que o mais espontaneamente

22. Até onde posso saber conforme notícia a respeito dada por José Guilherme Merquior, in O Marxismo Ocidental, Rio de Janeiro: Nova Fronteira, 19986, p.251. A resenha de Runciman é de 4 de outubro de 1984, London Revew of Books. pessoal, e a incorrespondente coerção lógica dos juízos determinantes de conhecimento. É claro que Habermas sabe muito bem disso tudo, tal seria. Por isto custa a crer que desde suas primeiras formulações programáticas, quando atinou com o último refúgio da Teoria Crítica, a exigência de emancipação sedimentada na estrutura da linguagem e reativada a cada frase pronunciada como uma vontade de consenso universal e livre de coerção, custa a crer que Habermas não tenha entrevisto em sua mais antiga máxima da interação simbólica - a verdade de um enunciado reside em última instância na antecipação de uma vida reconciliada - uma fundamentação análoga à da comunicabilidade geral, postulada pelo juízo reflexionante de gosto, e tudo o mais que daí decorreria para a própria autocompreensão da Teoria Crítica transformada pelo linguistic turn. Se tivesse puxado por este fio - que entre outras coisas amarra a Reflexão à Imaginação - seria quem sabe levado a admitir que a comunidade ideal de fala bem poderia ser uma comunidade imaginada, e o uma comunidade política certamente, cujo a priori, seria no entanto historicamente contingente, além de material, encravado na prática social do juízo.

Como lembrado, Hannah Arendt, perseguindo a mesma fundamentação discursiva das comunidades políticas, tomou explicitamente o caminho inverso, daí a referência direta a Kant, que omitimos em nossa longa citação para poder salientar melhor as partir de agora a originalidade de sua interpretação da Crítica da Faculdade do Juízo, acrescida é claro de sua surpreendente convergência com a compreensão retrospectiva da Nação como uma comunidade política imaginada. Como se há de recordar, no trecho em questão Hannah Arendt acabara de apresentar 
sua versão da característica básica do pensamento político, a saber, seu movimento discursivo, deslocando-se em imaginação de um ponto de vista para outro, um experimento mental em que se procura pensar como se estivesse no lugar de um outro ausente; só assim, dizia, graças a um tal exercício da imaginação, nossa capacidade de pensar se torna verdadeiramente representativa, no sentido político original indicado. Daí o parêntese e a referência ao parágrafo 40 da Crítica do Juízo, mais exatamente à máxima da faculdade de julgar, e que como tal concerne à maneira de pensar, pois não se trata aqui de uma faculdade de conhecimento, para voltar à distinção de que partimos: "é essa capacidade de dispor de uma mentalidade mais ampla (eine erweiterte Denkungsart) que permite aos homens o julgamento; como tal, ela foi descoberta por Kant na primeira parte de sua Crítica do Juízo, mas ele não reconheceu as implicações políticas e morais de sua descoberta”. Em suma, só posso julgar como membro dessa comunidade, cuja totalidade só é abarcável graças a tal processo pensante, convenhamos, inédito.

Se não estou enganado, e se não for um despropósito rebater sobre a filosofia política kantiana - que Hannah Arendt foi a primeira a redescobrir, não no seu lugar de costume, mas na sua teoria original de juízo de gosto, por ter sido desde sempre particularmente sensível ao caráter público da arte, como a seu ver era exatamente o caso de Kant - a invenção francesa da Nação ao longo da Revolução - e depois a sua invenção "americana”, durante a decomposição do Antigo Sistema Colonial -, seria então o caso de dizer que Kant, caso tivesse observado mais de perto a grande novidade histórica de que era contemporâneo, os processos enfim convergentes, porém distintos, de Nation making e State building, teria reconhecido na- queles artefatos alguma coisa que se poderia denominar de comunidades reflexionantes.

Antes de prosseguir, gostaria de me antecipar a uma possível impressão de disparate. Não ignoro que um iluminista confesso como Kant se declarava cosmopolita. Tampouco estou esquecendo que entre as alegações da inteligência ilustrada parisiense, para melhor confinar e estigmatizar a anomalia encarnada por Rousseau, não estava entre as mesma votadas a estreiteza provinciana das efusões patrióticas do Cidadão de Genebra. Todavia não é menos enganoso o anacronismo inverso, que consiste em entroncar diretamente no autor da Paz Perpétua, as divagações acerca de uma democracia ou "governança" cosmopolita, que costumam acompanhar o discurso globalitário acerca da convergência mundial transfronteira. Como parece que estamos caminhando para a formação de um império realmente global, congelando finalmente a hierarquia desigual na riqueza das nações e das classes, é sempre bom lembrar que no caso específico de Kant - para o qual ser cidadão só fazia sentido como membro de um sistema de direitos e deveres territorialmente limitado - a hipótese de uma monarquia universal aterrorizava-o como a ameaça do mais cruel despotismo. Por outro lado, devemos à implicância de Hannah Arendt com as frases fáceis dos que se autointitulam "cidadão do mundo", a observação certeira de que para Kant o "cidadão do mundo" era de fato um Weltbertrachter, um espectador do mundo. É assim, segundo o "modo de pensar do espectadores", o ponto de vista mesmo a partir do qual reflete desinteressadamente o homem de gosto, que julgará um acontecimento mundial como a Revolução Francesa ${ }^{23}$. Além do mais, tudo se passa

23. Cf. Hannah Arendt, Lições sobre a Filosofia Política de Kant, Rio de Janeiro: Relume Dumará, 1993, p.58. 
como se a mentalidade alargada que permite pensar na cabeça dos outros fosse por assim dizer a prerrogativa do espectador, mas de um espectador em condições de imaginar, digamos quase que intransitivamente. Daí o paradoxo, resolvido, de um cidadão do mundo que nunca saiu de sua remota cidadezinha prussiana: bastava alargar o próprio espírito do modo por ele mesmo indicado, imaginando o mundo através de todo o tipo de relatos de viagem, dos quais era leitor insaciável. Não surpreende assim a conhecida minúcia de seus cursos de geografia... imaginária. Uma outra observação preciosa de nossa autora, ajudará a reconhecer o terreno familiar no qual voltamos inesperadamente a pisar. Sabemos que Kant, ao responder à pergunta: "o que é o Iluminismo?" identificou a Era de Esclarecimento que se estava vivendo ao "uso público da própria razão em qualquer domínio", porém com uma restrição reveladora: "por uso público da própria razão entendo o uso que uma pessoa dela faz como um erudito diante do público leitor". Ora, repara Hannah Arendt, o erudito não é a mesma coisa que o cidadão, ele é membro de uma comunidade muito diferente, justamente a "sociedade dos cidadãos do mundo" ${ }^{24}$, quer dizer, espectadores do mundo, em suma, uma comunidade imaginada de intelectuais, uma comunidade reflexionante por excelência. Ocorre que essa República Internacional das Letras fazia tempo que deixou de falar latim, destroçado este último pelo capitalismo editorial em língua vulgar. De sorte que a razão kantiana só podia apelar para o tribunal dos cidadãos do mundo... em alemão, enfim uma coalizão de leitores, nos termos nossos conhecidos. A ser assim, o vasto mundo julgado à distância bem poderia ser o resultado de uma imaginação literalmente provinciana. 


\section{Eles sabem o que fazem*}

Não quero parecer ufanista, mas em matéria de cinismo também estamos na frente. Ou melhor, continuamos. Por mais que nos últimos quatro anos os atuais donos do poder e do dinheiro venham caprichando, graças sobretudo à contribuição original do principal homenageado desta praga comemorativa - como esquecer o imortal ato de contrição, para assinalar apenas uma entre várias obras primas do gênero, a confissão enternecida de que no pacote da crise asiática havia "maldades desnecessárias", cometidas contra quem de direito, é claro -, não se pode dizer que o cinismo seja uma ideia nova no Brasil. Para se ter uma noção de nossa espantosa atualidade no capítulo, bastaria recordar a luminosa franqueza com que nossos pais fundadores advogavam a causa ultramoderna do liberal-escravismo. Enquanto na metrópole um espesso véu vitoriano ainda recobria o interesse nu e cru do pagamento em dinheiro, numa longínqua sociedade colonial a exploração prosperava a céu aberto, direta e seca. No centro, todos faziam porém a rigor não sabiam de nada, ao passo que na periferia todos sabiam muito bem o que estavam fazendo. Só fomos alcançados nessa corrida do cinismo moderno quando o colapso anunciado da civilização burguesa madrugou na desenvoltura com que as novas elites imperialistas iam rifando velhas salvaguardas ideológicas (justiça, igualdade, etc.) sob pretexto (agora

* Publicado originalmente na revista praga n.6, 1998. 
abertamente cínico) de que encobriam uma conspiração dos fracos para sabotar a vitória dos fortes. Deu no que deu, o triunfo sob tortura da cínica frieza burguesa nos campos de extermínio.

Rompida desde o início dos anos 70 a barreira do decoro keynesiano, centro e periferias subalternas estão engajados novamente numa outra corrida ao cinismo total. Para variar continuamos na dianteira: toda vez que um gringo abrutalhado diz mata, há sempre um brasileiro esclarecido para dizer esfola. Voltemos então ao capítulo das “maldades desnecessárias". Numa carta oficial de agradecimento pelos serviços prestados por um ministro trapalhão - quanto a apertar botões na hora certa, mas não em confiscar poupança -, viu-se o destinatário agraciado com o título de "economista criativo", ficando subentendido que por motivo daquela barbaridade econômica, agora alçada à condição de instalação em Bienal. Não creio que esta alegação artística seja arbitrária. O banqueiro-professor encarregado de preparar a privatização da Previdência, enquanto amola a faca, vai tecendo considerações sobre a obra de arte que vem a ser o design de uma política econômica harmoniosa: câmbio desalinhado (para os filistinos) é antes de tudo uma questão de elegância. Acresce que a carta sobre a economia criativa, antes de chegar às mãos do artista desastrado (o confisco da poupança é uma dissonância, como os juros nos céus, um acorde perfeito), deve ter dado pequenas voltas nos círculos palacianos, não só pela lei do gênero, mas também porque o cinismo exige a roda restrita em que os mandantes acham graça nas respectivas armações. Só para sublinhar nossa incrível superioridade na matéria, não dá nem para imaginar, por exemplo, Jacques Chirac remetendo em público semelhante peça ao Ministro Juppé.
De onde nos vem a força dessa supremacia? Novamente de nosso economicismo de nascença, num momento em que as elites mundiais executam o programa suicida da economia com o supremo descaramento de quem acumula alegando conformidade a uma lei da natureza. Isto sem mencionar o fato de que os sucessivos planos de estabilização, precedidos por surtos inflacionários disciplinadores, funcionaram como formidáveis laboratórios de crueldade social, decisivos na cristalização do novo senso comum impregnado de cinismo economicista. Os efeitos desse sinistro vaudeville ideológico (modernismo econômico no topo, sociedade no ralo, escarnecida como bobagem metafísica) se encontram, mais uma vez, desigualmente distribuídos entre centro e periferia. Assim, a mesma máquina de guerra que se encarniça contra a excepcionalidade europeia, sente-se em casa no Brasil. Não é para menos: nascemos como entreposto comercial e estamos acabando como mercado emergente - eufemismo para circuito auxiliar de valorização patrimonial dos capitais que rodam o mundo. Como a força de trabalho escravo era contabilizada como um bem de produção, com direito a provisões para manutenção e amortização, não será difícil avaliar a magnitude do conforto moral e científico que o atual jargão da autenticidade econômica rende à boa consciência cínica dos herdeiros das segregações coloniais de sempre. Hoje como ontem, a ostentação da motivação econômica das condutas continua chique a valer, como diria o saudoso Dâmaso Salcede. 


\section{PARTE II}

O “PENSAMENTO ÚNICO” E O MARXISTA DISTRAÍDo

NEM TUDO QUE É SÓLIDO DESMANCHA NO AR

UTOPIA E REVOLUÇÃO

RECORDAÇÕES DA RECEPÇÃO BRASILEIRA

DE HERBERT MARCUSE

1968 TRINTA ANOS DEPOIS

MARX CULT

\section{O "pensamento único” e o marxista distraído*}

\begin{abstract}
"O primeiro princípio do pensamento único é de tal forma contundente que um marxista distraído não chegaria a negá-lo: o econômico leva a melhor sobre o político (...) A economia é colocada na posição de comando. Uma economia desembaraçada do obstáculo que representa o social, espécie de ganga patética cujo peso seria a causa de regressão e crise". Ignacio Ramonet ${ }^{1}$
\end{abstract}

1.

Como todo mundo sabe, pensamento único não existe, com ou sem aspas. A realidade é que é única, daí o consenso. Mesmo assim, num editorial do Le Monde Diplomatique, de janeiro de 1995, Ignacio Ramonet não só batizou o novo espectro que ronda o admirável mundo novo promovido pela globalização, como inventariou as mais notórias ideias fixas do personagem, pois o tipo é compulsivo e pensa abstratamente. A novidade do artigo

* Publicado originalmente em José Luís Fiori, Marta Skinner e José Noronha (org.) Globalização, o fato e o mito, RJ: Uerj, 1998.

1. Geopolítica do caos. Petrópolis: Editora Vozes, 1998, p. 74-75. Coleção “Zero à Esquerda". 
não estava evidentemente no repertório bem conhecido da apologética vencedora. Aliás, vencedora sem disfarce, foi-se o decoro do velho capitalismo. Como enuncia logo de saída o insuspeito Lester Thurow no Futuro do Capitalismo: acontece que o capital declarou guerra à força de trabalho e venceu, ponto. Estava na identificação de um estilo doutrinário inédito, pontuado, nos seus melhores momentos, por acessos de franqueza desse tipo - não é lá muito justo nem bonito, mas é assim que tem que ser. Outro exemplo, alguns pontos mais abaixo na escala do descaramento científico. Tirada de um formador planetário de opinião: o bom da recente crise asiática é que a economia coreana ficou agora sob o controle do Tesouro Americano. Inédito também pela abrangência sem resto da denominação "único", tanto por estar vedada a recusa - "there is no alternative", costuma martelar a Sra. Thatcher, aliás Tina -, quanto por ter engolido a velha esquerda - neste tópico, o exemplo vinha de casa mesmo: dois anos depois de eleito, François Mitterrand foi polidamente persuadido pelos "mercados", se é que queria mesmo tornar a economia francesa moderna e competitiva, como então se começava a dizer, a fortalecer a moeda, restringir o orçamento, desonerar o capital e renunciar ao quase pleno emprego, sem falar é claro nas distorções corporativistas por motivo de populismo macroeconômico etc. Assim, era novo não o velho mito requentado dos mercados autorregulados - cuja devastadora força destrutiva Karl Polanyi esmiuçou meio século antes - mas a estranha liga entre o furor pragmático dito de mero bom senso econômico e um furor ideológico inaudito no policiamento das opiniões desviantes do mais estrito darwinismo adaptativo.
Como todo mundo também sabe, com o fim do socialismo real e o triunfo quase planetário da democracia liberal - um verdadeiro sucesso de vendas - não existem mais regimes totalitários, como se dizia nos tempos da Guerra Fria. Mesmo assim, exatos dois anos depois, num outro editorial de janeiro de 1997, Ramonet cunhou nova fórmula para definir os sistemas sociais deste fim de século: "regimes globalitários", forma institucional do caminho único mapeado dois anos antes. Demasia retórica? Por certo uma infração à semântica histórica do termo "totalitarismo", de resto ele mesmo impreciso na caracterização do despotismo industrializante soviético, expressão por sua vez inadequada para o horror stalinista. Todavia em linha com análises que, à vista do programa suicida da economia - da precarização social generalizada ao colapso ecológico - reconhecem no fascismo a onda do futuro ${ }^{2}$. Se ainda assim a palavra fascismo arrisca desnortear, deixando escapar a originalidade do fenômeno, quem sabe seria menos abrupto o eufemismo "tirania soft", como sugerido num estudo de caso digamos doméstico, uma espécie de opressão difusa "sustentada por silêncios e consensos acerca do afastamento dos governos da gestão da

2. Cf. Edward Luttwack, "Por que o fascismo é a onda do futuro". Novos Estudos, Cebrap, São Paulo, nov. 1994. "O programa suicida da economia" é o título de um artigo de Robert Kurz, Os últimos combates. Petrópolis: Vozes, 1997, p. 183-189. Coleção “Zero à Esquerda". Pelo sim pelo não, não custa insistir: não se trata de um prognóstico catastrofista, mas do diagnóstico de uma esquizofrenia estrutural: todos sabem - relembra o autor - que a transformação radical da moeda em mercadoria, que de meio passou a ser fim em si mesmo, converteu o dinheiro num poder socialmente devastador, mas nem por isso deixam de manter os olhos vidrados nos rendimentos, assim como o coelho na serpente. Pelo menos neste caso, não me parece um exercício de quietismo político rever a catástrofe atual à luz daquela outra que Polanyi - a referência é explícita - imaginava ser a última, o retorno do reprimido na forma do apocalipse nazista. Assim sendo, "por que a opinião pública se mostra tão indignada com os voluntários suicidas do Hamas, se ela aceita de bom grado o programa suicida global da economia de mercado?". 
economia e da sua redução à administração disciplinadora de pessoas e forças políticas e sociais docilizadas (...) A mídia e os institutos de pesquisa de opinião pública em conjunto, evidentemente com um Banco Central independente, se encarregariam de estabilizar expectativas com relação à credibilidade do cassino [o Autor está se referindo ao tipo ideal de governabilidade que mais tarde - menos de um mês - poderia ser chamada então de "globalitária", o Principado de Mônaco, metáfora material e premonitória do capitalismo cassino contemporâneo], enquanto o príncipe [Ranier] inauguraria praças e compareceria a reuniões filantrópicas do corpo de bombeiros"3.

3. José Luís Fiori, "Por que governabilidade? Qual governabilidade?”, in Os Moedeiros Falsos. Petrópolies: Vozes, 1997, p. 43-44, Coleção "Zero à Esquerda”. Até onde sei este artigo foi redigido em dezembro de 1994, portanto um mês antes do editorial de Ramonet, prova de que o novo senso comum estava mesmo maduro para ser identificado e batizado. Como por aqui a esquerda sobrante estava recém comprando o peixe da "governabilidade" e seus derivados, a ênfase recaiu menos na característica de arrastão integrista registrada por Ramonet, do que no retrocesso bem brasileiro das unanimidades burras, além é claro de retraçar a genealogia da ladainha da "governabilidade" e seus derivados, que não é de ontem mas remonta às primeiras reações conservadoras às rachaduras na Pax Americana que estavam começando a ficar visíveis em meados dos anos 60. Voltaremos a este marco zero, inclusive do que viria a ser, depois da travessia do deserto ao longo da década de 70, a largada da famigerada globalização na origem dos "regimes globaritários”. Lembrei as datas para poder observar desde agora que numa conferência de abril de 1997 sobre o que denominou "a privatização do público e a anulação da política" no Brasil, Francisco de Oliveira por sua vez, também pareceu não ter hesitado muito antes de falar em "totalitarismo neoliberal", sancionando por outro ângulo a fórmula de Ramonet, mesmo descontando o choque que o emprego daquela palavra maldita sempre provoca. De qualquer modo, a seu ver, menos inadequada para traduzir a sensação difusa de sufoco sem brecha do que a expressão falsamente óbvia de "hegemonia", a esta altura uma aspiração no fundo otimista. A ser assim, "regimes globalitários" também se referem, nos termos do mesmo Francisco de Oliveira, àquela terra de ninguém (por assim dizer) "além da hegemonia, aquém da democracia". A conferência citada foi pronunciada no Seminário Internacional “A Construção Democrática em Questão" promovida pelo Núcleo de Estudos dos Direitos da Cidadania (NEDIC), São Paulo, USP, cujas atas serão publicadas proximamente na Coleção "Zero à Esquerda", Ed. Vozes. Ver do mesmo autor, os três últimos ensaios reunidos na Parte III de Os Direitos do Antivalor, Petrópolis: Vozes 1998, Coleção “Zero à Esquerda”.
Numa palavra, na de um sindicalista europeu, por exemplo os mercados governam, os governos administram; ou, na do presidente de um Banco Central do núcleo orgânico: pobre do governante que se deixar pautar por um pretenso debate nacional e se afastar da linha justa ditada pela finança mundial, será sancionado em tempo real. E assim por diante. Não estou citando à-toa estas amostras triviais da nova sabedoria comum - não por acaso, quando enunciadas pelos de cima, a meio caminho do axioma e da ameaça, quando repercutidas pelos debaixo, em chave de fatalidade meteorológica. Mas em apoio e ilustração de uma observação do próprio Ramonet, mais exatamente simples registro de uma sondagem recente de opinião, segundo a qual $64 \%$ dos franceses estavam convencidos - supondo-se que não sejam paranoicos nem neoburros - de que o poder real na França é exercido de fato pelos assim chamados mercados. Regime globalitário então é isso: além do mais se dá ao luxo de ser transparente e tagarela. Como se vê, não é nem um pouco difícil entender a unanimidade (burra? esperta?) que subitamente cercou a democracia, bem como a não menos óbvia e concomitante obsolescência das ditaduras militares e demais regimes de exceção. No Dezoito Brumário pelo menos, Marx fez (digamos assim) a burguesia pagar o alívio que lhe trouxe a capitulação bonapartista com uma espécie de estado de sítio moral, questão de impotência política e remorso pelo massacre do inimigo de classe. Barganha dispensável em "regimes globalitários", em que o triunfo espetacular do sufrágio universal converteu-se enfim no que já foi chamado de "bonapartismo soft"4 - afinal nasceram juntos

4. Por Domenico Losurdo, Democracia o Bonapartismo, Torino: Bolletti Boninghieri, 1993. 
até que, depois de incontáveis peripécias, os reunissem novamente a violência da moeda-mercadoria e os ritos plebiscitários igualmente fetichistas.

Juntando os dois editoriais, expandidos depois no livro que está nos servindo de mote, digamos que Ignacio Ramonet reuniu os elementos de uma experiência inédita no Ocidente capitalista há pelo menos uma geração, a experiência regressiva de uma sociedade sem oposição regressiva antes de tudo por decapitar o sentimento crucial do lado oposto, sem o qual não há nem mesmo vida do pensamento. Não custa reler um ou dois passos do panorama que acaba de ser exposto por nosso Autor, quando mais não seja para reavivar nossa imaginação oposicionista: “com efeito, um número cada vez maior de cidadãos sentem-se lambuzados, enganados por uma espécie de doutrina viscosa que insensivelmente envolve todo raciocínio rebelde, o inibe, perturba, paralisa e acaba por sufocá-lo (...) Por pouco seríamos levados a considerar que 20 milhões de desempregados europeus, o desastre urbano, a precarização generalizada, os subúrbios em polvorosa, a devastação ecológica, o retorno dos racismos e a maré dos excluídos como simples miragens, alucinações culpadas, fortemente discordantes nesse melhor dos mundos que o pensamento único está fabricando para nossas consciências anestesiadas". Como tudo isso é dito em bom francês, quer dizer, na língua do país clássico da Revolução e da Luta de Classes, era de se prever, sobretudo da parte de um cidadão livre e publicista, na acepção iluminista de ambos os termos, era de se prever portanto que se arrematasse o retrato de um mundo assim unidimensional, como o denominou certa vez Marcuse, no limiar de uma reviravolta para a qual ninguém sabia onde encaixar a alavanca, e no entanto pouco depois a primeira hegemonia america- na começava a descarrilar, era então de se prever, repito, que concluísse, como se viu, com um apelo não só à resistência, mas à contestação e à rebelião, lembrando que nas presentes circunstâncias, a revolta é uma obrigação e a insurreição um direito. Resta saber com que roupa, para não falar em classes sociais e virtualidades emancipatórias objetivas - e creio que para isso estamos reunidos aqui, se é fato que somos todos zero à esquerda, espero que em fim de hibernação ${ }^{5}$. Não se trata apenas de que oposição não se inventa, embora tampouco seja uma flor espontânea da imanência. Ocorre que a própria identificação do huis-clos de um pensamento dito único (“... a repetição constante, em toda mídia, desse catecismo por quase todos os políticos, tanto de direita quanto de esquerda") carrega consigo a experiência mesma de que falávamos, a saber que vivemos precisamente numa sociedade sem oposição - excluída a acepção politicamente trivial da palavra, bem como a sugestão descabida de que senso comum, como parece ser o caso que nos ocupa, embora seja um sedimento de ideologias fósseis, se obtenha apenas por inculcação e manipulação.

\section{2.}

Dito isso, vamos ao ponto que me interessaria destacar na cena do "pensamento único" reconstituído por Ramonet. À certa altura deu-se o disparate, um traço a mais porém decisivo para a virada que nos derrubou. Assim como a

5. Reunidos em Seminário, “Globalização: o fato e o mito”, Programa Universitário de Estudos Estratégicos, UERJ/UFRJ, Rio de Janeiro 13/15 de abril de 1998. 
vida, para Oscar Wilde, tinha passado a imitar a arte, a realidade também passou a imitar o marxismo, ou, para ser menos injusto, o atual curso do mundo tornou-se um pastiche do marxismo vulgar. Exatamente nestes termos não devo a observação a Ramonet, mas a um outro alto personagem que referirei no seu devido tempo, quem sabe num outro Seminário, que emende no de hoje, é claro ${ }^{6}$. Parto assim mesmo da boa anotação de Ramonet, além da citada em epígrafe, a saber: nada mais parecido (estou exagerando um pouco, mas não muito), com o "pensamento único" de que o marxismo (ou um certo marxismo) do qual parece ter adotado, por uma espécie de caricata força das coisas, a pretensão ingênua à cientificidade (o círculo inescapável da razão), a evocação escatológica do futuro radioso, a indiferença com respeito aos seus próprios fracassos (a irrefutabiliadade das próprias teorias de abrangência máxima, que por definição não se dei-

6. Pensando melhor, não custa já ir adiantando o serviço. Estou me referindo às reflexões de Roberto Schwarz acerca da atualidade de Brecht, mais exatamente tendo em vista as circunstâncias modificadas de hoje que obrigam a encenar a Santa Joana dos Matadouros (traduzido por Roberto no começo dos anos 80) de uma maneira bem deslocada em relação ao que foi a intenção do escândalo brechtiano original, que era o escândalo do motivo econômico. Acontece - continua Roberto Schwarz - que a partir de determinado momento - as datas variam, para um frankfurtiano de carteirinha, por exemplo, a partir da Segunda Guerra Mundial; para a nossa discussão de agora, todavia, a partir da desregulação apologética do até então capitalismo organizado pelo Welfare State, o que muda muito: uma coisa era o capitalismo que segundo Adorno estava apagando a distância entre ideologia e realidade, comprometendo a velha matriz materialista da crítica da ideologia ainda em pleno funcionamento no teatro épico; outra, a "naturalização" do econômico entregue a si mesmo enquanto sua própria norma, o que não era o caso de sua domesticação politicamente explícita do período anterior - então: "a partir de um determinado momento, o capitalismo começou a reconhecer que a sua mola era econômica (...) que o necessário economicamente está certo (...) Então, o grande escândalo da peça de Brecht, o primado da economia, continua sendo engraçado, mas em si mesma essa tese deixou de ser uma tese rebelde", Roberto Schwarz, "A Atualidade de Brecht", Revista Vintém-Ensaios para um texto dialético, n.1, São Paulo: Editora Hucitec/Companhia das Letras, 1998, p. 34. xam desmentir nem corroborar pelo varejo das evidências empíricas), mas sobretudo o paroxismo farsesco da determinação econômica em última instância7. Assim como parece, por outro lado, indiretamente claro que no "totalitário" que se conjugou ao "global" do "globalitário" está muito presente o figurino soviético da opressão, bem como o Partido de mil olhos no único do pensamento dito único e suas instituições - os aparelhos ideológicos dos regimes globalitários: por exemplo, as fábricas de "ideologia" que são os think tanks das fundações americanas, sem falar nas redes acadêmicas, enquanto a ditadura do dirigismo político total da economia transferiu-se, invertendo a simetria, para a ditadura dos mercados sobre a sociedade, e o posto de comando, assumido às claras pela economia, exercido na gesticulação autoritária como uma contrafação involuntária porém legitimadora da extinta economia de comando.

Há mais surpresas ainda no capítulo dos arremedos. Um outro exemplo dessas inesperadas semelhanças de família - depois que o mundo mudou de base, ou melhor transpôs desordenadamente o subsolo oculto da exploração para o andar de cima -, mas agora no âmbito da pedagogia histórica, do tipo: aprenda com o inimigo. - Num balanço da escalada neoliberal rumo ao poder mundial, disseminando nessa marcha triunfal ideia única de que não há alternativa para os seus princípios - só com lembrete, entre outros "princípios": que a desigualdade social é um valor positivo e só ela poderá voltar a dinamizar as economias avançadas -, Perry Anderson chegou à seguin-

7. Por onde emendamos - como disse - na paródia involuntária da sátira brechtiana, ameaçada de redundância. Mas por enquanto meu fio condutor é mesmo Ramonet, cf. Geopolítica do Caos, p. 94. 
te conclusão: "trata-se de um corpo de doutrina coerente, autoconsciente, militante, lucidamente decidida a transformar todo o mundo à sua imagem, em sua ambição estrutural e sua extensão internacional, muito mais parecido com o movimento comunista de ontem do que com liberalismo eclético e distendido do século passado (...) A tarefa dos seus opositores é de oferecer outras receitas e preparar outros regimes. Apenas não há como prever quando ou onde vai surgir. Historicamente, o momento de virada de uma onda é uma surpresa". ${ }^{8}$ Nada contra a estratégia da hibernação, desde que socialmente organizada. Creio até que se poderia reforçar o argumento já que nosso autor está interessado no estudo profilático de um fenômeno de hegemonia (perfeita? fraudulenta?) como nunca se viu antes no mundo gerado pelo capital: "ainda que, naturalmente, milhões de pessoas não acreditem em suas receitas e resistam a seus regimes [isto foi dito em setembro de 1994, no Rio de Janeiro] (...) provavelmente nenhuma sabedoria convencional conseguiu um domínio abrangente desde o início do século como o neoliberal hoje" - lembrando que para Gramsci (pois não se trata de hegemonia?) o aparentemente fluído liberalismo do oitocentos não era bem uma emanação natural das leis de movimento da esfera da circulação, mas antes uma regulação induzida por vontade política e imposta por uma sábia combinação de lei e coerção. Isso posto, nada ficou dito sobre o encontro das águas no momento da virada de onda e a subsequente metamorfose de uma revanche ideológica, remoída durante décadas de ressentimento, no império alucinante de um verdadeiro senso comum. Sem

8. Perry Anderson, "Balanço do neoliberalismo", in Emir Sader e Pedro Gentili (orgs.), Pós-neoliberalismo, Rio de Janeiro: Paz e Terra, 1995, p.22, 23. querer forçar demais a nota, adianto que o fundamentalismo do "pensamento único" não seria tão avassalador se a realidade não lhe respondesse com um correspondente economicismo fundamentalista, como se houvesse um achatamento dos dois lados - no fundo as coisas ficaram mais simples. Numa palavra - que não sei se terei chance de retomar no decorrer desta exposição: tudo se passa como se na ruptura de época que estamos atravessando, ideologia e realidade corressem uma para outra. Assim sendo, a boa comparação com o movimento comunista não seria com a sua história prévia, que não foi consumida em doutrinação à espera de uma falha no sistema que se desviara de sua natureza (no caso da Sociedade de Mont Pélerin, uma espécie de maçonaria neoliberal, o mito do mercado autorregulado), mas com o sinistro vaudeville do socialismo real em seu último estágio: a cada reviravolta de uma comédia de extorsão e engodo em que ninguém enganava mais ninguém, cristalizava-se uma sorte de aspiração geral pelo polo oposto implícito naquilo tudo, de modo que o marxismo soviético acabou fornecendo razões a favor do capitalismo antes do seu triunfo.

Embora noutra direção, uma observação recente pode servir de complemento. À certa altura de uma análise e interpretação do caráter destrutivo do que chama utopia neoliberal - "um programa metódico de destruição dos coletivos" - Pierre Bourdieu ${ }^{9}$ chama a atenção para o fato de que ela suscita uma crença assustadora não somente nos seus clientes naturais, a classe empresarial de alto bordo, financistas à frente, mas também, e com ênfa-

9. Cf. Pierre Bourdieu, "L'essence du néoliberalisme", Le Monde Diplomatique, março de 1998. 
se redobrada, nos altos funcionários e assemelhados, dos políticos profissionais aos consultores econômicos, ciência acadêmica incluída, que lhe devem - ao "pensamento único" e seu grão de utopia fundamentalista - sua própria razão de existir. Difícil dizer neste caso - um caso igualmente destrutivo e ensandecido de utopia epistemológica, a utopia da teoria pura, mais exatamente a da racionalidade em seu grau máximo de decantação das impurezas do real - onde termina o auto engano dos beócios (que inclusive dissertam a respeito), e principia a fome canina dos cínicos. Seja como for, esta casta de oficiantes e beneficiários diretos do "pensamento único" administram o "horror econômico" em curso, que de qualquer modo não podem ver (agora, na acepção epistemológica deste obstáculo), pois esse processo tende sempre a transformar em realidade a utopia ultra consequente - como certas formas de loucura à qual eles a bem dizer consagram a vida. Compreende-se que considerem demente - é só lembrar as impressões de viagem de Ramonet: somos levados a considerar a devastação de nossos dias como uma alucinação culpada e dissonante, enfim caso para internação psiquiátrica, aliás desnecessária pois o grande renfermement do nosso tempo se dá por expulsão - toda tentativa de crítica dessa loucura internalizada sob forma de realidade (voltaremos ao ponto ). Pois é pensando nesses funcionários do "pensamento único" que Bourdieu repara de passagem - sem nenhuma explicação adicional - que essa utopia da exploração sem limites, que vem a ser afinal a do neoliberalismo, tem mais de um traço em comum com o marxismo de outros tempos. Não quanto ao conteúdo, imagino, mas no que concerne a simbiose entre uma ideologia de granito e os respectivos aparatos de poder. Com certeza devia estar pensando no marxismo soviético. E em par- ticular, na nomenklatura. O que sem dúvida diz muito a respeito da convergência sistemática dos dois modelos antagônicos, a começar por esse funcionamento ideológico aparentado, em fim de linha um, triunfante outro, porém igualmente predadores e "totalitários". Por onde se vê sem muito exagero - como é frágil a contraposição doutrinária entre Estado e economia de mercado, quando na verdade se trata - neste caso particular - de dois aspectos institucionais, sem dúvida diversos, de politização de um certo economicismo de base, e agora também ideológico deste lado outrora "ocidental". Confirmando o parentesco da casta neoliberal com a nomenklatura (do despotismo esclarecido à corrupção endêmica), Bourdieu evoca, me parece que sem querer, pois não vinha ao caso àquela altura do artigo, um dos procedimentos científico-burocráticos terminais daquela última, e ao qual já me referi há pouco, a internação psiquiátrica dos dissidentes, espécie de paródia involuntária e grotesca (volto a repisar) de Foucault, ao lembrar que o "pensamento único" não é um discurso como os outros, mas um "discurso forte", como Erving Goffman denomina o discurso psiquiátrico no espaço asilar: como o psiquiátrico, o discurso neoliberal (ou que nome tenha a fraseologia do nosso tempo) só é assim tão forte, e por enquanto imbatível, "porque conta a seu favor com todas as forças de um mundo de relações de força que ele contribui: para ser tal qual é, obviamente orientando as escolhas econômicas daqueles que dominam os circuitos econômicos, acrescentando assim a sua força específica, propriamente simbólica, a essas relações de força”. Assim funciona um programa metódico de destruição dos coletivos - como no seu antigo primo rico, o marxismo soviético, podemos supor. 
Uma derradeira amostra do disparate que está nos ocupando, a saber, a incrível semelhança entre a vulgata marxista e o "pensamento único", seja lá qual for o estatuto desconhecido desse rolo compressor de frases feitas e abstrações mortíferas também denominado, como se está vendo, ora "utopia neoliberal", ora "discurso social dominante". Amostra colhida ainda no cenário francês em que principiamos a desenrolar o nosso fio. Refiro-me à grande greve de dezembro de 95, que embora restrita ao setor público contou com a simpatia inequívoca da população - para surpresa do governo, que apostava como sempre na divisão da sociedade. Essa virada de dezembro de 95, o tournant inédito para os novos tempos, com o qual ninguém contava mais. Sem embargo de todos os limites, para dizer o menos por ora, inerentes a um combate de retaguarda. Não custa relembrar, antes de voltar ao desconchavo em pauta, além do mais nas palavras de um autor insuspeito de qualquer simpatia populista, clássica ou macroeconômica, pelo contrário é até de opinião de que aquele combate foi o último de uma série histórica, a da emancipação negativa pela luta de classes, que a seu ver bateu no seu teto histórico - mais uma razão, acrescento, para entrever nesse provável término, o primeiro de uma outra série, num outro registro do conflito emancipatório. "A greve de dezembro em Paris contou com tamanho apoio porque de fato os grevistas - um tanto inconscientemente - subiram no ringue como representantes de todos os assalariados. Somente à primeira vista, estavam em jogo as aposentadorias dos ferroviários [de resto bem modestas, no juízo do próprio autor, noutro trecho do mesmo ensaio] ou o seguro de saúde dos funcionários públicos (idem, ibidem). Na verdade, o alvo do protesto era o consenso liberal das elites [o outro nome do nosso "pensamento único", desde que incluamos no amplo arco de tal consenso, o entusiasmo novo rico tanto da velha esquerda quanto da nova, ajustada à realidade é claro, agora experts consultores em adaptação, como prefere falar o autor que estou citando]. Foram as irritantes declarações sobre a imprescindibilidade da chamada redução dos custos sociais que atiçaram a bile das massas francesas. E com toda razão. Há muito se sabe que a matança social é generalizada e que a faca para o nosso pescoço já se acha amolada". ${ }^{10}$ Mas o que até então não se sabia - o mais espantoso na grande provocação de que estamos tratando, que de manobra camuflada como todas as provocações, tornou-se como que espontânea - é que o próprio marxismo se encarregaria de amolar a faca - pouco importa se apenas um aleijão com

10. Robert Kurz, "Os últimos combates: o maio parisiense de 1968, o dezembro parisiense de 1995 e o recente acordo trabalhista alemão”, in Os últimos combates, ed. cit., p.300. Pequeno repertório dessas declarações irritantes, inspiradas por uma mistura de "arrogância" de elite recém-convertida à apologética de modernização e o costumeiro desprezo de classe pelo estorvo que vem a ser a inépcia adaptativa dos de baixo. Essa "arrogância" (qualquer leitor brasileiro entenderá as aspas) de tipo novo não por acaso começou a ser notada por suas vítimas à medida que se alastravam pelo mundo os assim chamados ajustamentos macroeconômicos impostos pela famigerada retomada (aos trancos) da hegemonia americana - tópico ao qual cedo ou tarde voltaremos. Assim, a greve seria a expressão exasperada de: "defesa de privilégios", "demagogia desavergonhada", "conservadorismo a qualquer preço", "egoísmo corporativo", "epidemia de reinvindicações que levarão ao suicídio coletivo". Enfim, coisa dos "bem aquinhoados", crispados em torno dos eternos "direitos adquiridos", e por isso mesmo, como era de se esperar, apoiados por uma "pequena burguesia proletaróide", isto é, intelectuais ressentidos. Cf. Jean Pierre Le Goff, "Le grand malentendu", in J.P. Le Goff / Alain Caillé, Le Tournant de Décembre, Paris: La Découverte, 1996 - que não deixa de observar por sua vez, que o descaramento quase espontâneo de considerar o trabalho assalariado vinculado a um sistema público de proteção social contra a vulnerabilidade, inerente à condição de classe social não-proprietária, um "privilégio", caradurismo pavoneado pelos apóstolos da "austeridade" (que aliás preferem o eufemístico rigueur), sejam eles intelectuais mediático-políticos, especialistas da constatação e do comentário "a favor", ou da consultoria no domínio da modernização, ou realejo-propagadores como os âncoras de tele-jornais, os quais evidentemente de modo algum se consideram "privilegiados", também se explica (tal desfaçatez) por um incontrolável impulso de arrivista ameaçado (cf. op.cit., p. 25). 
cara de marxismo, conta muito mais a naturalidade com que os reflexos pavlovianos das elites dominantes foram se assemelhando ao materialismo histórico.

Assim, no auge do movimento grevista, volta e meia pipocavam silogismos de impecável "marxismo legal"11, como o seguinte: segundo Marx um movimento social deixa de ser tal se não se mostrar capaz de elevar os interesses de um grupo particular ao plano superior do interesse geral (convenhamos que não era preciso recorrer a Marx para sustentar essa lapalissade sociológica, o que ainda acrescenta algo mais ao grotesco da invocação do alto patrocínio de Marx); ora, a greve não ultrapassou os limites acanhadíssimos da defesa e ilustração da teratologia de sempre, os tais “direitos adquiridos”, sabe-se lá como, direito de conquista sem dúvida, pior ainda, "direitos adquiridos" do setor público, como todo mundo sabe um setor refratário à "formidável mutação em andamento", além do mais encasulado na não menos famigerada excepcionalidade nacional francesa; portanto não se trata de um verdadeiro movimento social, mas sim de um "movimento imaginário" apoiado pelos eternos organizadores do ressentimento social, os intelectuais passados para trás, como aliás é do ofício deles, os sobrantes pelo menos ${ }^{12}$.

11. "Na Rússia <da virada do século>, paradoxalmente, o marxismo - além de constituir uma teoria alternativa em relação à posição revolucionária anticapitalista dos populistas (narodniks) - proporcionou uma certa justificação à missão histórica do capitalismo (...) O marxismo representou, assim, a base para o curioso fenômeno dos marxistas legais", Eric Hobsbawm, História do Capitalismo, vol. III, São Paulo, Paz e Terra 1989, p. 84. cf. Paulo E. Arantes, Diccionário de Bolso do Almanaque Philosophico Zero à Esquerda, Petrópolis: Vozes, 1997, pp. 49-50.

12. Cf. "Militante Imaginário", Diccionário de Bolso, ed. cit., p.16. O silogismo "marxista legal" em questão se deve ao raciocínio "realista" (v. Realismo) de um "militante realmente existente" (Mirex), cf. Id. Ibid., pp. 16-17.
Acresce que neste caso particular, a desautorização da greve fechava com uma citação de $\mathrm{Gramsci}^{13}$. É bem verdade que o terreno propício ao florescimento desse estereótipo paramarxista (para distraído ver) foi preparado pelo que já foi chamado de "economicismo de esquerda" que marcou a virada ideológica da Era Mitterrand na direção de algo como - mais ou menos no jargão francês autorizado - um projeto de gestão da mundialização ${ }^{14}$. Dito isso, o registro desse notável sinal dos tempos por um observador bem próximo dos acontecimentos: "considera-se o marxismo morto e enterrado. E no entanto, é o mais vulgar dos marxismos que serve de doutrina oficial ao Estado liberal. Não há medida que não seja anunciada sob a rubrica de uma necessidade objetiva identificada de uma vez por todas como a lei máxima do capital. E sendo assim, toda oposição a essa 'necessidade' objetiva - é associada à reação 'pequena-burguesia' atrasada, resistindo em vão ao que o sentido da história ordena"15. Vai na mesma direção a notação de um outro observador, não tão próximo assim, feita porém igualmente no calor da hora: "paradoxalmente, hoje é o governo [Chirac/Juppé] que age em nome de uma exigência universal e com o pathos da necessidade histórica, mas cujo verdadeiro caráter é o apelo negativo que subjuga o homem à legalidade cega

13. Cf. Pascal Perrineau e Michel Wieviorka, "De la nature du mouvement social", Le Monde, 20.12.1995. O resumo crítico em forma de silogismo é de Jacques Rancière, "Les raisins sont trop verts", lido no original que acabou não sendo publicado no jornal Le Monde.

14. Desde que a esquerda abandone a "lógica da recusa", é claro e, não sem tempo, se modernize, admitindo de uma vez por todas que o neoliberalismo não existe e que o mundo não é necessariamente a jungle. Cf o mesmo Wieviorka de há pouco, "La gauche et la logique du refus", Le Monde, 13.05.1996.

15. Jacques Rancière, op.cit. 
de um sistema corrompido"16. Segundo o mesmo Robert Kurz que acabei de citar, na origem desse paradoxo se encontra uma dialética peculiar (e não estou abusando do termo "dialética", salvo engano), responsáveis por essa inversão do mundo - o "notável sinal dos tempos”, na reação pasma de Jacques Rancière -, mais exatamente de sua expressão política herdada: o mundo inverteu-se de tal sorte no seu contrário, que "a reação entre conservadores e progressistas, direita e esquerda, governo e oposição, foi posta às avessas"17. Por nossa conta já dá para perce-

16. Robert Kurz, op.cit., p. 284.

17. Id. ibid., p.282. Seria bom não perder de vista que na outra ponta, na invenção burguesa da esfera política separada, e que culminou no anticlímax do golpe bonapartista de 2 de dezembro de 1851, Marx também descreveu um quiproquó semelhante, digamos o período "ingênuo" (para falar como Schiller) da comédia fetichista entre liberais, conservadores e progressistas sociais, cuja intriga se desenrola com as bolas trocadas: constitucionalista conspirando contra a Constituição; revolucionários que se declaram constitucionalistas; monarquistas apoiando uma república que detestam; um poder executivo que deriva sua respeitabilidade do desprezo que inspira etc; enfim na fórmula famosa que resume essas antinomias em cascata: "em nome da ordem, uma agitação selvagem e sem objeto; em nome da revolução, solene pregação em favor da ordem". Digamos que o ciclo terminal em que entramos corresponde ao período "sentimental" daquela antiga comédia de erros, quer dizer uma idade reflexiva e abertamente cínica. Assim - para voltar ao ensaio de Kurz sobre o dezembro parisiense de 1995, redigido sem dúvida com o Dezoito Brumário diante dos olhos - "o conceito de reforma social deixou de ser progressista e foi adotado pelos conservadores; deixou de significar incremento social e passou a significar regresso ao capitalismo brutalizado de Manchester no século XIX. Após transformar o conceito de reforma social em seu contrário e infundi-lo com conteúdos antissociais, o governo já pode criticar os sindicatos e as associações sociais com um cinismo inaudito taxando-os de incapazes para a reforma. Hoje isso acontece não apenas na França, mas em todo o mundo. As esquerdas vestem a máscara de conservadoras e os sentimentos ressurgentes de solidariedade e entusiasmo prendem-se curiosamente à esperança de que tudo deve continuar como está (...) Se tudo deve continuar como está, os milhões de desempregados, desabrigados e novos-pobres que existem também na França permanecerão, em última instância, excluídos da solidariedade", op.cit.,pp. 282, 283. Mas por outro lado, advogando a causa tautológica da mudança pela mudança, como um fim em si mesmo, o "pensamento único" inibe e congela seu contrário justamente para que tudo continue como está, de preferência emoldurando o quadro com um passepartout de clichês extraídos da vulgata marxista. - Uma formulação sociológica insipidamente conformada com essa outra consequência paradoxal da modernidade - aliás nada para- ber - para não dizer que salta aos olhos - que na base dessa coreografia farsesca está o pastiche do marxismo pela realidade, por motivo de divórcio litigioso entre economia e sociedade ${ }^{18}$, em que o desencapsulamento da primeira implica a destruição da segunda, é claro que em nome de um mirabolante desbloqueio das forças produtivas, como se repete noite e dia na língua de chumbo do economicamente correto.

\section{3.}

Para começo de conversa, é preciso pelo menos admitir que não é apenas o sangue que ferve diante de tanta desfaçatez: o show diário de cinismo das elites econômicas globalizadas que afinal chegaram ao cúmulo de impingir a falência social do seu sistema (alguém duvida que é o capitalismo que não tem alternativa para a humanida-

doxal se lembrarmos que não só em arte faz um bom tempo que vanguarda e conformismo social andam juntos, de sorte que os termos do nosso problema poderiam ser repassados da seguinte maneira: assim como um modo de produção condenado a revolucionar seus próprios instrumentos produtivos, sob pena de perecer, sendo portanto destradicionalizante por definição, termina por incorporar e suplantar a dimensão de choque da arte de vanguarda, que na falta de adversário se espraia na rotina mercantil e iconoclasta de algo como um modernismo realmente existente, não surpreende que por outro lado também passe a imitar o materialismo histórico, no seu tempo vanguarda da crítica social -, pois uma variante hoje consagrada e normalizada dessa troca de papéis entre esquerda e direita, escamoteada a fraude do reformismo antissocial, encontra-se na mesma sem cerimônia com que Anthony Giddens anuncia já estar acima de esquerda e direita que além do mais inverteram suas posições respectivas: estilização de um modo de produção que ao se globalizar retomou seu ímpeto revolucionário; nada menos conservador do que o neoliberalismo enquanto o socialismo passou para a retaguarda, tentando proteger no melhor estilo conservador-defensivo, o que sobrou do Welfare State. Cf. Anthony Giddens, Para Além da Esquerda e da Direita, São Paulo: Unesp, 1995.

18. Do qual se fala há pelo menos uma década ou mais. Cf. por exemplo, Bernard Perret, Guy Roustang, L’Économie contre la Societé, Paris: Seuil, 1993. 
de?) como uma lei natural a ser aceita e a cuja bitola todos têm de se adaptar - para voltar a falar nos termos em que o mesmo Kurz de há pouco parafraseia o mundo posto de cabeça para baixo pelo economicismo vitorioso. Mas também a cabeça, no mínimo nocauteada pela própria imagem no espelho. Falo é claro da cabeça de um "marxista distraído". Resta saber se foi apanhada por essa miragem somente a variedade progressista identificada por Ramonet. É questão de por a mão na consciência e refletir: quando os hierarcas do poder mundial e seus sátrapas regionais mentem deslavadamente ao dizer a verdade (e vice-versa) não seria o caso de verificar se a critica marxista não se tornou redundante? Ninguém ignora que os sinais se apresentam descaradamente trocados: houve um tempo em que destravar uma instância oculta e recalcada era uma promessa de liberação; hoje o desmascaramento que revela o domínio exercido por uma determinação primária é sobretudo uma ameaça claramente dirigida aos recalcitrantes, acompanhada entretanto por um aceno de participação no botim aos que se acotovelam na bilheteria. Pois mesmo assim é forte a impressão de estar arrombando uma porta aberta.

Há mais, todavia, neste exame preliminar de consciência. O que diz a cantilena do "pensamento único" enquanto vai embalando populações postas de joelho pelo flagelo da inflação (na periferia) e pela chantagem da precarização social (no centro)? Mais ou menos o seguinte: como a sociedade repousa sobre fundamentos materiais - é só a esquerda passadista e lacrimejante que parece ignorar esse dado imediato da experiência social -, a racionalidade econômica da qual depende o incremento civilizatório das forças produtivas (afinal, o materialismo histórico, como a psicanálise muito tempo antes, não virou senso comum?), passa à frente de qualquer consideração imaterial: justiça, igualdade, direitos (mais uma vez: sobretudo se "adquiridos" por conta de relações salariais obsoletas) são pura superstição, lixo sentimental, reminiscência populista etc, enfim bobagem. No que concordam as vítimas do "ajuste": pior que a exploração é não ser explorado, e assim como a primeira passa a atender pelo nome eufemístico de "emprego", a moeda forte (a qualquer preço estabelecido pelos "mercados") se reapresenta (como no primeiro pós-guerra de 14-18) como o bem supremo da sociedade humana. Pois é neste cenário que desliza o "marxista distraído", enquanto o desperto, se quiser mesmo reverter a síndrome baluartista que o paraliza, faria bem se reconsiderasse com um olho histórico o modo ambíguo com que sempre encarou os feitos materiais e ideológicos da finada burguesia.

Por um lado, o nominalismo inerente à desmistificação materialista - o avesso exato do reconhecimento da existência espantosa de abstrações reais comandando a vida das pessoas - mandava rebaixar o palavrório enroscado no entusiasmo com que as ideias de liberdade, igualdade etc enchiam os pulmões da gente burguesa, de sorte que o anticlímax da crítica esfriava a poesia da compra e venda da mercadoria força de trabalho entre proprietários livres e iguais à medida em que, se embrenhando no subterrâneo prosaico da produção, chamava pelo nome os interesses em jogo. Relidas assim dessa maneira recuada, aquelas palavras enormes revelavam o fundo falso da mais reles empulhação. Daí o choque, a ser devidamente investido pela consciência que ele desperta, à vista do 
próprio reflexo invertido devolvido pelo realejo do "pensamento único", diante da manifesta assimetria de duas posições formalmente superpostas porém cinicamente embaralhadas pelos vencedores de agora: num caso, o engodo a que se resumiriam os universais burgueses depois de desossados pela critica era de fato coisa de nenhum valor, porém descartado por uma classe social a cujo esbulho dava cobertura moral, e como todo mundo sabe, moral é um luxo que só as classes proprietárias podem se permitir; no outro caso, a desautorização vem do alto, como se o nominalismo plebeu próprio das classes perigosas, como sempre, desabusadas, ascendendo aos céus da dominação social, escorasse o mesmo raciocínio porém na ordem inversa: de fato, justiça, igualdade e tudo o mais aparentado que apele para os bons sentimentos dos bacharéis em direito, é mera parolagem, porém esse entulho metafísico é uma emanação socialmente subalterna, na verdade uma fantasia encobridora do desajustamento histórico das classes "negativamente privilegiadas" (se a ordem é citar Weber, por que não?), para não falar no ressentimento dos perdedores, que por isso mesmo se agarram à velhas regalias enquanto caluniam os vencedores e suas batatas. Repetindo: o sangue pode e deve ferver, mas o fato é que com vassouradas ora à esquerda, ora à direita, a falecida ideologia burguesa foi sendo varrida para de baixo do tapete. É bem verdade que com uma razoável ponta de remorso no caso da oposição socialista à civilização burguesa triunfante.

Aqui voltamos ao outro lado na ambígua relação crítica do materialismo histórico com o liberalismo, enquanto cultura de abrangência máxima na legitimação do capitalismo histórico. Deste outro ângulo, que não anula o primeiro, antes reequilibra o encaixe da crítica, as grandes frases em que se sublima a reprodução material da ordem burguesa não são ocas ou acintosamente diversionistas, mas falsas apenas na medida em que pretendem descrever uma realidade que teima em não lhes dar razão, são portanto falsas promessas, como já disse um clássico: a crítica progressista do liberalismo - não por acaso, este último, a matriz original de todo progressismo - "não questionava os ideais de humanidade, liberdade e justiça, mas sim a pretensão da sociedade burguesa de se apresentar como a realização desses ideais. Para ela as ideologias eram aparências, mas aparências da verdade". Noutros termos - nos da grande tradição filosófica herdada e decifrada no seu enigma como formalização coerente do capitalismo enquanto metafísica realmente existente: é só lembrar das cabriolas teológicas da famosa mesa sensorialmente suprassensível -, a realidade por assim dizer não corresponde ao seu conceito, há um hiato na forma de um antagonismo não resolvido, entre a realidade existente e as tendências emancipatórias que ela a um tempo libera e aprisiona. Revistas as coisas por essa ótica, percebe-se que mesmo a crítica fulminante do edifício ideológico assentado na livre troca de equivalentes é regulada pelo direito natural, sobre o fundo do qual se destaca então o esbulho de uma apropriação sem equivalente, e o correspondente sentimento objetivo de injustiça que o economicismo vencedor reduz a pó, por vício de irrealismo é claro, fechando-se o círculo em que por sua vez se debate o "marxismo distraído" às voltas com as tendências objetivas do polo dinâmico da acumulação etc.

Retornemos à fronteira em que esbarramos, ao limite surrealista onde nos defrontamos com o nosso duplo, o "pensamento único" que não só apanhou de surpresa 
o "marxismo distraído" e o arrastou consigo na trilha da apologia indireta, mas arrisca igualmente deixar falando sozinho as variantes menos desatentas, se não for presumir demais. Vimos que esse tropeço histórico não assumiria as proporções desastrosas que tomou se não fosse a ambiguidade de origem dos movimentos sociais antissistêmicos, que se contrapunham por via da imanência ao mundo gerado pelo capital. Reprisando: quando a cultura estabilizadora desse sistema histórico polarizador é medida pela distância interna que separa o real do possível que o subverte e transcende, um "reflexo conciliador recai, senão sobre a realidade existente" - para voltar a citar o clássico de há pouco - "pelo menos sobre as suas chamadas tendências objetivas". E se as ideologias fossem algo pior do que meros disfarces apologéticos? Continuo citando: não seria um contrassenso imaginar que reviradas as ideologias pelo avesso, coincidindo assim com a sua própria verdade, deveriam modificar uma situação cujo fardo em princípio deveriam suportar? Pelo contrário, não seria a própria realização dessas promessas descumpridas o impulso fatal que ajudaria a transformar (como se viu na crise de entreguerras) a sociedade da livre concorrência na sociedade da opressão imediata? (Fim de citação). Daí a cega desenvoltura com que esse supplément d'âme do "pensamento único" (o "marxismo distraído" que trazemos adormecido em nossa alma progressista) revoga direitos sociais (arrh!) - em pensamento, é claro -, pois subordinou a forma vazia do direito, a um tempo simples véu ideológico, e no entanto demandado por motivo de violação, à lei imanente do contrato entre proprietários de mercadorias.

Em tempo: 1) seria o caso de lembrar, antes de passar adiante, que não se trata de eliminar essa ambivalência de fundo? Que ela está fincada numa espécie de implicação mútua entre imanência sistêmica - caso cedêssemos à tentação de rifar essa dimensão, resvalaríamos para a terra de ninguém da utopia, cabendo à imaginação socialista o magro consolo de filtro moral - e transcendência antissistêmica, cuja carga negativa ficaria no entanto sem efeito caso não fosse organizada em função dos níveis civilizacionais alcançados? 2) mas seria sim o caso de lembrar que: a) como já foi bem observado, a evolução histórica da espécie humana sempre se deu por uma adaptação passiva do quadro institucional da sociedade à pressão das forças produtivas; b) a novidade da modernidade capitalista (com perdão da redundância) reside no fato de que pela primeira vez essa pressão material não só é autoimpulsionada pelo imperativo da criação destrutiva permanente mas solapa também em permanência as formas de legitimação herdadas, provocando por sua vez novas rodadas de adaptações passivas; c) o Manifesto Comunista diz exatamente isso, só que de um outro modo, o que faz toda a diferença, a saber, que esse mecanismo de reprodução social em que a iniciativa cabe apenas à inovação econômica define o caráter fetichista da até então pré-história da humanidade, luta de classe incluída, ela mesma expressão por sua vez da evidência de que os homens não fazem sua própria história nem consciente, nem voluntariamente; d) e conclui pela revolução que se impõe em função dessa tomada subversiva de consciência desfetichizante: consumada essa reviravolta em que por uma rotação ciclópica de eixo o mundo mudará de base, o controle prático das transformações estruturais da sociedade passará para as mãos de indivíduos autônomos e cooperativos, encerrando - não custa repetir - o ciclo fetichista de submissão absoluta do metabolismo social às suas condições materiais de reprodução, revelada pela crítica no instante mesmo em que se apresenta a perspectiva histó- 
rica de revirá-la pelo avesso, transformando em adaptação ativa o que até então era sujeição movida a autoengano ideológico quanto ao presumido desenvolvimento geral do espírito humano; e) assim sendo, o atual pastiche do marxismo - que então se vulgariza na exata medida em que é posto de pernas para o ar, à vista do programa emancipatório do Manifesto parodiado como mera interpretação econômica da história, em que pese toda a boa vontade de um Schumpeter - o atual pastiche do marxismo pela realidade, repito, apenas demonstra, como se fosse preciso, a sinistra sobrevida da pré-história fetichista da humanidade: quem vê um Novo Renascimento na atual mundialização do capital deve usar atravessado no nariz uma lasca de osso difícil de confundir com um alto-relevo de Donatello, lapso que é claro passou desapercebido, como era de se esperar da integração sistêmica invisível própria das sociedades primitivas; f) não por acaso, a nova apologética atribui a falência do socialismo ao incremento exponencial da "incerteza artificial" por motivo de "globalização", livremente entendida como um "espantoso processo de mudança estimulado pela incessante expansão dos mercados”, deslocando em consequência - não menos linear - o vínculo iluminista entre conhecimento e controle, e com ele o enunciado socialista do Manifesto, segundo o qual os indivíduos enquanto humanidade coletiva seriam capazes de controlar a vida social na condição de autores do próprio destino; o que era assim pesadelo da esquerda - jamais despertar para a vida consciente - tornou-se ambição da direita, pesadelo acordado em que ideologia e realidade correm uma para a outra. "Pensamento único" também deve ser isso. Sobretudo pela distância demandada, a partir da qual o encanto se quebraria: a um só tempo quase nada e infinita.

\section{Nem tudo que é sólido desmancha no ar*}

Como a mais absoluta dominação sobre os homens continua a ser exercida através de processos econômicos de exploração - mesmo sobre a crescente parcela da humanidade que está sendo rifada precisamente porque deixou de ser economicamente rentável - o Manifesto Comunista ainda cruzará o milênio como uma mensagem na garrafa. Muito mais atual inclusive do que há 150 anos atrás, quando a proletarização dos pobres e demais expropriados ainda não parecia irreversível, a ponto de um considerável número deles procurar escapar à danação do assalariamento - só viver se encontrar trabalho, e só encontrar trabalho se este incrementar o valor do capital - reagrupando-se à margem da ordem burguesa nascente na forma de comunidades cooperativas, por meio das quais sonhavam recuperar a antiga independência econômica perdida. Porém a Modernidade anunciada pelo Manifesto viera também para abortar o não-lugar dessa utopia. Com a atual mundialização do capital enfim, ninguém mais está fora, sobretudo as grandes massas precarizadas e desconectadas na corrida ao corte de custos: em tempos de pressões competitivas globalizadas, literalmente não têm mais para onde ir. Nunca estiveram tão irremediavelmente incluídas.

* Título de uma novela inédita de Jorge Miguel Marinho. Texto originalmente publicado na revista Estudos Avançados, USP, n.34, 1998. 
Continuamos portanto na mesma, a mesma desgraça econômica de sempre, desde que a terra, o trabalho dos homens e a moeda de troca entre eles foram transformados em mercadoria, como qualquer outro artigo de comércio. Mas também continuamos na mesma numa outra acepção igualmente sombria da expressão, por assim dizer mítica. Era o que Marx e Engels queriam dizer, no momento mesmo em que chamavam a moderna exploração econômica pelo nome, ao declarar que a história de todas as sociedade tinha sido até então a história da luta de classes. Pois bem: se toda a história é história da luta de classes é porque a história sempre foi a mesma coisa, numa palavra, pré-história. Como de resto se pode ler num dos rascunhos preparatórios do Manifesto: "assim como a forma mais recente da injustiça lança luz sobre todas as demais, a crítica da economia é uma crítica da história no seu todo, de cuja imobilidade a classe dos capitalistas, como outrora seus antepassados - senhor de escravos, patrício romano, barão feudal -, deriva o seu privilégio (...) O silêncio arcaico das pirâmides repercute o barulho infernal do sistema de fábricas". Não por acaso - numa conhecida interpretação - para o poeta das Flores do Mal (livro rigorosamente contemporâneo do Manifesto Comunista), essa mesma e famigerada Modernidade era a cifra de um mundo sempre-igual de ruínas recorrentes, as destruições criativas, no vocabulário da apologética mais recente, próprias de um sistema que não pode subsistir sem a morte precoce de seus instrumentos de reprodução. Assim, no suposto auge renascentista que estaríamos atravessando - a chamada globalização, na opinião apoteótica de um varão sabedor local -, no rumo sabe-se lá de que apogeu econômico futurista, não se achará muito mais do que outro espasmo pré-histórico do sistema tautológico a que se resume a ab- surda e interminável acumulação de capital comandada pelo único e exclusivo fim de se acumular mais capital.

Tudo isso não obstante, é fato que Marx e Engels não resistiram à tentação progressista da época, deixando-se impressionar pela nova prosa modernista do mundo, pela irresistível escalada dos preços baratos da mercadoria burguesa tomando de assalto quantas muralhas da China lhe surgissem pela frente. E como poderiam, naqueles tempos de legitimação "revolucionária” dos acumuladores de dinheiro e poder? Mas ocorre que deslizando pelo plano inclinado da modernolatria deram com a plataforma de uma outra humanidade, a qual corresponderia enfim verdadeiramente ao seu conceito, É que entreviram naquela novidade avassaladora do capitalismo em relação às civilizações anteriores a chance providencial de quebrar o feitiço pré-histórico da alienação. Nunca será demais evocar o essencial dessa reviravolta. E para realçar a nota dissonante do Manifesto neste final de século de harmonia extorquida, por que não evocá-lo nos termos mesmos das teorias sistêmicas em voga? Com efeito, não é muito difícil admitir que a evolução histórica da espécie humana sempre se deu por uma adaptação passiva do quadro institucional da sociedade à pressão das forças produtivas. A ser assim, a inovação da modernidade capitalista reside na circunstância sem dúvida inédita de que pela primeira vez essa pressão material não só é autoimpulsionada pelo imperativo da acumulação infindável mas solapa, também em permanência, as formas culturais de legitimação social herdadas, provocando por sua vez novas rodadas de adaptações passivas. Ora, ao contrário de uma solene declaração burguesa 
de reconhecimento e sanção de tendências históricas consumadas, o contradiscurso do Manifesto simplesmente demonstra que contra tais fatos há argumentos, além do mais fornecidos por eles mesmos. A saber: que esse mecanismo de reprodução social em que a iniciativa cabe apenas à inovação econômica define justamente a pré-história da humanidade, e que portanto o capitalismo ele mesmo é pré-histórico, não espantando que nele ainda se apresente como um destino o cego movimento da economia; e que tal engrenagem não saltará dos trilhos enquanto uma rotação ciclópica de eixo não passar o controle prático das transformações estruturais da sociedade para as mãos de indivíduos autônomos e cooperativos, encerrando assim a idade mítica de submissão absoluta do metabolismo social às suas condições materiais de reprodução. (E pensar que hoje quem se "ajusta", e não por acaso mediante sucessivas e infinitesimais adaptações passivas, acredita que nesse último enunciado jurássico da causalidade sistêmica se concentra a quintessência do materialismo histórico, em nome do qual de alma leve pede a benção aos vencedores).

Está claro porém que o encanto não se romperia por simples decreto emancipatório, que não basta apontar para a fantasmagoria para que ela se dissipe. Além de ser materialmente tangível, a peça subversiva que faria girar a porta de saída da pré-história precisaria pertencer ela mesma ao encadeamento arcaico que mandaria pelos ares. Estava assim designado o lugar a ser ocupado pela luta de classes: à mola perpetuadora da eterna recaída na barbárie seria delegada a tarefa de encaixar a alavanca numa muralha aparentemente sem brecha, se é fato que haveria mesmo um grão de transcendência na assimetria brutal de poder social entre as classes em luta. Nesse entorse da pré-história, Marx e Engels apostaram todas as fichas da emancipação.
Ou quase todas: é bom não esquecer a ressalva acerca da ruína comum que também espreita o conflito de morte nessa guerra social por onde corre ainda a pré-história da humanidade. Como se essa reviravolta não bastasse, Marx e Engels repetiram uma segunda vez naquele mesmo Manifesto a prova do caráter pré-histórico do capitalismo: sacudida por crises periódicas em que o capital torna redundante sua própria fonte de valorização queimando força produtiva, a sociedade burguesa "vê-se subitamente reconduzida a um certo estado de barbárie" que se abate sobre os indivíduos como outrora a fome e as guerras de extermínio, só que agora na forma invisível de poderes subterrâneos autônomos e incontroláveis. Nessa segunda prova dos nove - a experiência da impotência social máxima no confronto com as forças anônimas da exploração - ressaltava novamente a novidade histórica do capitalismo: sob o invólucro ultramoderno do progresso, a derradeira sociedade primitiva, mergulhada na inconsciência coletiva do desastre que se avizinha. Digamos então que o essencial do Manifesto reside na figuração contemporânea do nexo entre essas duas formas pré-históricas da opressão: a primeira contrapondo campos sociais antagônicos e visivelmente personificados; a segunda, a dominação, sem sujeito designado, exercida sobre o conjunto da sociedade pela economia de mercado autonomizada, a ponto de transformar os seus beneficiários diretos em meras funções de seu próprio aparelho de produção. Uma dimensão não vai sem a outra, assim como o proletariado do Manifesto se exaure enfrentando ora a burguesia, ora o capital, do qual a primeira é "portadora involuntária e incapaz de reação", na fórmula do Manifesto, mas nem por isso desprovida de vontade e do poder de disposição sobre os homens que lhe confere um sistema que por sua vez a sujeita se não quiser perecer, como aliás se 
pode ler noutro rascunho famoso redigido dez anos depois, os Elementos Fundamentais para uma Crítica da Economia política: "na redução dos homens a simples agentes do mercado se esconde a dominação de homens sobre homens. Porém a classe dominante não é apenas dominada pelo sistema, domina através do sistema. A tendência objetiva do sistema é redobrada e sancionada pela vontade constante daqueles que o servem. Como é cego, o sistema é a própria dominação, e por isso mesmo funciona sempre a favor dos dominantes, mesmo quando os ameaça de ruína; os trabalhos de parto a que eles se entregam nos momentos de crise atestam o pleno conhecimento desse fato".

$*$

Estando assim entrelaçadas as duas dimensões desse diagnóstico do capitalismo como derradeira sociedade pré-histórica - ele mesmo cifra de uma ruptura de época tanto mais paradoxal por implicar um momento de autorreflexão da espécie humana sob o mais espesso invólucro de uma segunda natureza - compreende-se que nenhuma das duas pode sobreviver à morte da outra. Os trinta anos de calmaria que sucederam a última grande guerra - efeito anestésico da guerra fria, do Welfare europeu e da industrialização consentida da periferia -, varreram da memória o abismo entreaberto pelo apocalipse nazista, na verdade cavado pela mítica espiral da normalidade burguesa, o envolvimento pré-histórico da luta de classes na engrenagem da exploração econômica. Há menos de duas décadas rompeu-se o dique novamente. Como um sinal de alarme entre duas catástrofes, o Manifesto Comunista ainda continua soando, ontem como hoje, para despertar a humanidade do mesmo pesadelo ancestral da dominação.

\section{Utopia e revolução*}

Acho que dificilmente alguém se arriscaria a empregar a palavra Revolução na sua acepção histórica original neste início do século XXI. A sensação prevalecente é de que a Era das Revoluções se encerrou de vez, e com ela teriam se esgotado as energias utópicas do nosso tempo. Basta olhar para as expectativas rebaixadas no Brasil dos últimos anos e a opção preferencial de suas elites pela mediocridade, que a famigerada "utopia do possível" resume tão bem. Trata-se, é bem verdade, de uma anomalia, pois historicamente a mentalidade utópica sempre foi um sopro vital vindo de baixo, das camadas oprimidas da sociedade. Para os conservadores do século passado era a rebelião das massas que constituía uma ameaça à civilização; hoje ela vem do alto, é o mito neoliberal do mercado autorregulado que trouxe de novo a peste ao mundo. Há quem fale em utopia a propósito desse fundamentalismo de mercado, pensando por certo na linhagem autoritária das utopias da ordem absoluta, muito embora a tirania do mercado seja a da mais completa e destrutiva anarquia. Mas com certeza o espírito da utopia que está nos interessando ver renascer é muito diferente desse e de outros pesadelos passados. É bem verdade que uma dialética sinistra costuma converter o impulso utópico no seu exato contrário, mas não se trata de uma fatalidade, longe dis-

\footnotetext{
* “Entrevista inacabada de uma pergunta só" a Florência Ferrari e Stélio Marras, integrantes do corpo editorial da Sexta Feira. Publicada em 2001.
} 
so, uma razão a mais para refinar nossa percepção histórica. Num livro recente, Russel Jacoby, justamente sobre o pretenso fim da utopia, procura desmontar a lenda que atribui toda a violência política dos Tempos Modernos aos sonhos utópicos dos deserdados.

Voltando ao forte sentimento de que a Era das Revoluções chegou ao fim, é preciso cautela. Afinal quem poderia antever a implosão da sociedade supostamente unidimensional, cujo diagnóstico os teóricos de Frankfurt fecharam com tanta ênfase como o fim de linha de um mundo totalmente administrado? E no entanto também esse mundo caiu, como derreteu o iceberg soviético sem que sequer uma ogiva fosse disparada. Mesmo assim, sendo irrecusável a percepção de estarmos atravessando uma verdadeira ruptura de época, pela primeira vez pressentimos com um certo calafrio que já não podemos mais dizer que a História está do nosso lado - estou falando é claro da esquerda, dos grandes derrotados do século XX. Quer dizer - nos termos em que vocês formularam a questão -, o movimento ascensional da Revolução Francesa à Revolução Russa, simplesmente estancou e saiu de cena. Seria o caso de dizer o mesmo do impulso utópico libertário que pelo menos as deflagrou? E que por sua vez elas abafaram, para no entanto renascer adiante? Como nitidamente estamos num limiar, não será demais uma digressão retrospectiva. No futuro do socialismo - se ele ainda tiver algum - algo terá a ver com esses momentos memoráveis em que ruptura histórica e imaginação utópica se cruzam. Ou não?

Seria um pouco descabido falar em "revolução" a propósito das Guerras Camponesas no início do século XVI, na Alemanha. Sem falar no fato de que naqueles tempos rebeliões camponesas eram tão correntes quanto as greves no mundo industrial, como já se observou. Mas no caso da irrupção milenarista numa guerra camponesa daquele porte, pode-se dizer - como o fez Mannheim que a revolução foi por assim dizer inventada como um valor em si mesmo e não como um meio para se alcançar algum fim socialmente calculado, era a brecha por onde se insinuaria algo como a atualidade absoluta de um presente transfigurador. Curiosamente, o que não deixa de ser revelador, o mesmo Mannheim achava que uma tal espiritualização da política - essa transcendência de imagens incongruentes com o curso normal do mundo - poderia ser vista como a certidão de nascença da política tal como a conheceríamos mais tarde com a entrada em cena de liberais e socialistas. Até aqui Mannheim, procurando apartar a ideologia dos integrados da utopia dos outsiders. É bom não esquecer que Engels viu na heresia plebeia de Thomas Münzer a instauração imediata do Reino de Deus. Sobretudo o comunismo de um precursor, dissimulado por uma fraseologia profética. Porém, foi preciso esperar que uma sensibilidade política formada na atmosfera anticapitalista da Grande Recusa característica do expressionismo alemão, como foi o caso de um Ernest Bloch, para que o espírito utópico daquilo que parecia mera "fraseologia" fosse tomado ao pé da letra, a consciência antecipadora entranhada nos sonhos diurnos, nos sonhos para frente, como dirá, por oposição à marcha retroversa dos sonhos noturnos da psicanálise. Não estou fazendo esse rodeio à toa. Se afinal estamos interessados em vislumbrar uma política para a esquerda no século XXI, e portanto, na reconstrução de uma Teoria Crítica à altura da atual reconfiguração do capitalismo global, será do maior 
interesse não perder de vista essa primeira manifestação do acento utópico, sem o qual o esforço de emancipação ficaria privado de sentido, e uma Teoria Crítica radical mal se distinguiria de uma análise estrutural da dinâmica de crises sistêmicas.

O caso inglês ajudará a esclarecer esse ponto, além de constituir o primeiro capítulo de nossa Era das Revoluções. Como se sabe, a Revolução Puritana se distingue por um quiproquó de semântica histórica. Uma guerra civil que opôs o Parlamento à Monarquia, culminando num rei decapitado e uma República proclamada, sem falar na gigantesca reviravolta social e econômica na origem dessas peripécias políticas, passou para a história imediata apenas como uma rebelião a mais, verdade que uma Great Rebellion, ao passo que a Restauração posterior da realeza, em condomínio é claro com as prerrogativas parlamentares das novas classes proprietárias, recebeu a chancela de uma revolução, além do mais gloriosa, a Glorious Revolution, na acepção astronômica original da palavra, embora de modo algum se tratasse de um retorno ao ponto de partida inicial. A verdadeira revolução obviamente foi a primeira, tanto é assim que acabou fornecendo, justamente como a francesa, no século seguinte, o estereótipo das chamadas revoluções burguesas, sem falar no roteiro básico para as rupturas socialistas vindouras. Marx costumava dizer que era próprio dessas revoluções ditas convencionalmente burguesas enganaram-se a si mesmas quanto à sua verdadeira natureza de classe; assim, recorriam a reminiscências históricas (Antigo Testamento nos tempos de Cromwell; história romana no auge jacobino) para camuflar com o verniz sublime de um passado heroico o raso prosaísmo dos interesses em jogo, sem o que lhes faltariam a energia e o entusiasmo para levar até o fim a sua tarefa de liquidação do Antigo Regime. Enfim, era necessário que a fraseologia suplantasse a estreiteza do conteúdo, enquanto na revolução social do futuro seu conteúdo de verdade dispensaria tais excessos de imaginação, seria enfim, por uma vez, realista. A essa altura, alguém poderia confrontar tal prognóstico com um slogan famoso de Maio de 1968: sejamos realistas, exijamos o impossível. Pois foi justamente um historiador emérito da Revolução Inglesa, Christopher Hill, marxista ainda por cima, mas nem por isso menos impregnado pela ambiência libertária das jornadas de Maio de 68, que aliás deu a volta ao mundo, e na França, em particular, desaguou na maior greve de massa de que se tem notícia numa economia industrial moderna, pois foi na esteira dessa nova sensibilidade (que para alguns autores encerra em 68 o longo ciclo das revoluções históricas, desfecho reprisado em 89 com a Queda do Muro de Berlim, inaugurando uma outra longa marcha de contestações antissistêmicas, que mais adiante trataremos de identificar) que Christopher Hill recontou uma outra história da Revolução Inglesa, uma outra revolta no interior da Revolução, protagonizada por grupos radicais como os diggers, os levellers etc, para ficar nos mais conhecidos. A seu ver, houve duas revoluções na Inglaterra em meados do século XVII. A que venceu foi a da gentry e dos grandes comerciantes que tornou o mundo seguro para os homens de negócio, escorado firmemente pela soberania parlamentar, monarquia limitada, política externa imperialista e sobretudo, pela triunfante ética protestante do trabalho. A institucionalização de tudo isso não precisaria esperar até a gloriosa restauração de 1688, se não tivesse sido bloqueada ou pelo menos retardada por um período de fabulosa mobilidade social e 
fermentação intelectual, ao longo do qual, sempre segundo Christopher Hill, literalmente qualquer coisa parecia possível, em que o mundo pareceu, por momentos, ficar de ponta cabeça (como aliás anuncia no título do livro [O mundo de ponta cabeça]), como se as hierarquias sociais e as estratificações do decoro pudessem ser permanentemente invertidas, enfim e mais uma vez, como se o reino dos céus pudesse ser alcançado na terra, acrescido de um tempero inédito de franca sensualidade. Tivesse essa verdadeira "utopia militante" triunfado, e teria quem sabe estabelecido um sistema comunal de propriedade, uma democracia de verdade, e com certeza repudiado a famigerada ética protestante, quer dizer, nem mais nem menos que o próprio espírito do capitalismo nascente. O relato de Hill se encerra com a lição do Marcuse teórico das grandes reviravoltas dos anos 60: liberação da imaginação pelas grandes revoluções da história, no entanto logo sacrificada quando a nova ordem revolucionária entra nos eixos. (Embora não cite, é bem provável que Christopher Hill tenha simplesmente atinado com o filão carnavalizante da cultura popular, cuja subversão em ato Bakhtin estudara no mundo de Rabelais. Mas isso já é uma outra história). Voltando a 68, é bom não esquecer que nem sempre a imaginação no poder é a salvação da lavoura, como demonstra, para começar, a própria "herança impossível” legada pelo Maio de 68 segundo Jean-Pierre Le Goff, pensando (não só ele) na metamorfose liberal dos libertários daquela revolução cultural que acabou alimentando a teoria e a prática de "flexibilidade" do novo capitalismo em rede.

Pois bem. Pode-se dizer que a revolta dos diggers em meio à Revolução vencedora é responsável pelo curto verão de uma "utopia concreta", na acepção que lhe deu o marxismo profético de um Ernest Bloch. Os diggers estão na origem de um dos primeiros atos radicais desses grupos não-conformistas: simplesmente começaram a ocupar terras improdutivas e cultivá-las por sua própria conta e de modo comunitário, proclamando tratar-se de um direito dos pobres, cujo acesso ancestral às terras comuns já estava sendo vedado pela crescente disseminação dos "cercamentos" senhorias. Reforma agrária como ação direta, em suma. Essas comunidades Digger, que não foram concebidas apenas para resolver o problema econômico de seus protagonistas imediatos, segundo nosso Autor, caso se alastrassem e vingassem, poderiam funcionar como o embrião de uma outra civilização, desta vez francamente emancipatória. Relembrada essa virada memorável que não se efetivou, podemos avaliar a mutação da sensibilidade política radical em nosso tempo. Meu termo de comparação, no caso, vem a ser um livro muito original de duas estudiosas inglesas, Sue Branford e Jan Rocha, sobre o MST, que tenho a intenção de publicar na coleção Zero à Esquerda, não por acaso intitulado Turning the world upside down e ao longo do qual, como enunciado no título, situam o nosso MST na mesma linhagem histórica daqueles mesmos grupos radicais cuja utopia em ato poderia ter mudado o rumo da Revolução. Aqui o ponto: por isso mesmo, visto assim em perspectiva histórica, não se deveria mais encarar o MST como um movimento revolucionário "clássico", com o vento da história soprando a seu favor, na direção da conquista "socialista" do poder - pelo qual se interessa tão pouco quanto os zapatistas, com os quais de resto costuma ser comparado com frequência. Há algo de milenarista nesse movimento de protesto e resistência que nada tem de arcaico, pelo contrário, nossas duas autoras chegam a vislumbrar nele um espírito muito além da sensibilidade sacrificial do velho socialismo de com- 
bate, uma cultura de liberação que não temem qualificar de "pós-moderna", querendo com isso designar um conjunto de iniciativas propriamente pós-capitalistas, por assim dizer de uso imediato em benefício das pessoas, da economia camponesa, solidária e sustentável, à luta pela desmercantilização das sementes, passando por uma reformulação total da noção de educação básica. Como diria Naomi Klein, o MST, como outrora os diggers, também estão "reclaiming the commons", bem entrincheirados no vasto front antiglobalitário dos ativistas que não estão esperando mais por uma remota "revolução" mas empenhados em remover aqui e agora as novas enclosures por meio das quais o grande capital corporativo e seus patronos políticos estão privatizando e patenteando todos os recursos da vida coletiva no planeta. Nesse limiar civilizacional, reforma agrária é muito mais do que mera posse da terra. Não que essa agenda, por assim dizer, "imanente" ao sistema tenha caído em desuso (suplantada pela maior eficiência econômica do agrobusiness ...) mas que se sobrepôs uma segunda dimensão apontando para a vida possível além do mercado, transfigurando-a inteiramente.

Com a Revolução Francesa entramos finalmente em terreno conhecido - sobretudo porque ela fixou de uma vez por todas na imaginação das gerações futuras a "ideia" mesma do que se deveria entender por revolução. Basta lembrar o modo pelo qual os bolcheviques durante as peripécias da Revolução Russa recorreram às reviravoltas revolucionárias e contrarrevolucionárias da matriz francesa para "figurar" as suas próprias, tiveram até um Termidor (stalinista, como se sabe). Como ainda estamos nos prolegômenos, vamos acelerar o passo. A ideia "astronômica” de que se trata de uma outra revolução-retorno, a restauração das antigas liberdades francesas usurpadas pelo despotismo da monarquia absoluta, não dura mais do que um brevíssimo momento. Logo se viu que nem mesmo se tratava de uma sedição ou mais uma revolta: pela primeira vez se impunha a experiência inaugural dos tempos modernos, a de uma avalanche incontrolável, irreversível, enfim a ideia mesma de uma torrente com sentido próprio arrastando consigo uma multidão persuadida da qual, no entanto, era a protagonista de um processo que claramente a ultrapassava. Em suma, estava ali, em movimento, a matéria-prima das grandes narrativas filosóficas e romanescas vindouras. E também a certeza de se estar em presença de uma instauração absoluta do novo, um momento inaugural sem precedentes, cujo marco zero era uma Declaração, graças à qual, a Revolução se apresentava como fundada nos Direitos da Humanidade, nem mais nem menos, de modo que os homens se viam transfigurados e renovados em todos os aspectos, do político ao moral. Utopia em ato, portanto, que alguns viveram como uma verdadeira ultrapassagem da história, cujo curso inexorável, entretanto, estavam presenciando como uma série de catástrofes fatais. Nas palavras sempre citadas de Michelet, tudo se passava como se o próprio tempo tivesse sido abolido, suspenso o seu curso num perene estado de graça revolucionária em que tudo enfim seria possível. Mito ou não, o fato era que pela primeira vez confluíam e se confundiam a tradição do pensamento utópico e a nossa tradição que se inaugurava, a do pensamento histórico. Já posso ir adiantando que nesse traço de união entre História e Utopia, o filósofo Jürgen Habermas reconhecerá a cifra mesma da modernidade, só que devidamente expurgada de sua origem revolucionária. Chegaremos lá, e à Utopia substitutiva que ele propõe no lugar da exaurida utopia da sociedade do trabalho, como, à sua manei- 
ra, entende a falência da ideia socialista, sobrevivência de uma primeira idade industrial. Um terceiro elemento entrou em cena com a Revolução Francesa. Refiro-me à Questão Social. Até onde sei, Hannah Arendt foi a primeira a assinalar o caráter crucial dessa irrupção em massa dos pobres na arena revolucionária. Ressalve-se o anacronismo terminológico, pois a expressão "questão social" torna-se corrente apenas a partir dos anos 1830, significando o reconhecimento enfim da existência escandalosa de populações pauperizadas pelo processo mesmo de industrialização da qual eram os agentes indispensáveis. Anacronismo compreensível pois Hannah Arendt está pensando entre tantos outros motivos polêmicos que deixarei de lado (como o caráter nefasto das políticas miserabilistas), no modo pelo qual Marx interpretou o caráter inconcluso da Revolução Francesa: falhara na fundação da liberdade por ter se detido na metade do caminho da resolução da questão social, concluindo por fim que liberdade e pobreza são incompatíveis. Noutras palavras, da mesma Arendt, fazendo um balanço dessa primeira revolução social interrompida, Marx se deu conta que era preciso pensar a pobreza de massa em termos políticos, e mais, como uma sublevação por uma questão de liberdade, e não apenas de pão, o que seria reiterar a ditadura da mera necessidade. Esse o ponto explosivo, segundo nossa Autora e que lhe permitirá avaliar a funesta virada das futuras revoluções socialistas. Mais uma vez: a Revolução Francesa ensinara a Marx a reconhecer na penúria maciça das classes despossuídas uma força política explosiva, mas nem por isso imaginou que o socialismo pudesse vir a ser pensado como uma sociedade de afluência voltado exclusivamente para a eliminação da escassez, soterrando sob o produtivismo modernizador a utopia de uma socie- dade emancipada fundada na liberdade. Dito isso, faltaria acrescentar um derradeiro elemento ao nosso quadro: a partir de 1789 entra em cena a figura social do "revolucionário”. Durante a Revolução Inglesa, surgiram, como vimos, "agitadores", e dos mais radicais, mas ninguém que pudesse afirmar estar "fazendo" uma revolução, quando muito experimentando uma. Agora a Revolução é alguma coisa que se faz, e a expressão de uma vontade política que culmina na conquista do poder. Quando a Revolução Social finalmente entra em cena em 1848, emergindo da brasa dormida deixada pela Grande Revolução, a batalha final (e o massacre de junho) se dará justamente em torno dos controles do mando político central, o Estado passava a ser o alvo primordial da Revolução, conduzida por um "partido" de revolucionários. É esse o modelo que um século e meio depois entraria em crise, senão em extinção.

Mas vejo que preciso apertar o passo. Na verdade dar um salto um tanto arbitrário até a Revolução Russa. No resumo de um teórico dos sistemas mundiais, Giovanni Arrighi, o esquema básico de Marx, segundo o qual a acumulação capitalista a um só tempo fortalece socialmente o proletariado como produtor de riqueza material e o despoja nessa mesma proporção, na medida em que precisa desvalorizar a mercadoria força de trabalho, de tal sorte que ao fundir assim numa mesma classe o poder social e a penúria de massa estaria preparando a sua própria deslegitimação política como sustentáculo da ordem burguesa - pois esse esquema, segundo Arrighi, não podia prever uma disjunção fatal entre o poder social crescente da classe operária, porém sem consequências políticas revolucionárias decisivas, de um lado, e de outro, a via de fato revolucionária seguida por um proletariado acossado pela penúria endêmica que afetava igualmente os demais gru- 
pos e classes subordinados, como o campesinato, e uma disjunção tanto mais fatal quanto espacialmente localizada, quer dizer, acompanhando a polarização do sistema entre centro e periferia: assim, nas economias modernas do núcleo orgânico, o poder social do proletariado tornou-se cada vez maior, porém a revolução socialista não conseguiu ganhá-lo, enquanto na semiperiferia (para ser exato) a revolução venceu, mas em nome de um proletariado que não tinha nem teria poder social. Foi este último o caso da Revolução Russa e uma das razões de sua posterior reversão trágica. Naufrágio histórico de um modelo que adotou entre outras estratégias igualmente fatais, a estratégia dos dois passos, como a denominou Wallerstein, e cujo embrião exemplar se encontra, como vimos, na Revolução Francesa, a saber: primeiro a conquista do poder, depois a transformação do mundo. Na opinião do mesmo Wallerstein, uma estratégia autodestrutiva (selfdefeating), em função da limitação do poder de Estado na economia-mundo capitalista, um espaço econômico de acumulação hierarquicamente distribuído por jurisdições políticas em competição, visando justamente ascender na referida hierarquia ou então simplesmente não se deixar rebaixar e dominar. Ao tomar o poder central nessas condições, os movimentos antissistêmicos acabam fortalecendo o próprio sistema de concorrência interestados, exercendo inclusive as funções de classe dominante em relação às suas próprias populações, por mais igualitários que tenham sido os seus propósitos originais, sem mencionar o fato de que a desconexão anti-imperialista, inaugurada pela via soviética da economia de comando, condenava o país aos horrores da acumulação primitiva num só país, transformando-se aos poucos numa única fábrica em regime de caserna.
A esse respeito recomendo o livro de Fernando Haddad sobre o sistema soviético (O sistema soviético: relato de uma polêmica), da editora Scritta. Aliás, não por acaso, num ensaio recente e ainda inédito do mesmo Autor, reencontramos noutros termos a mesma crítica à estratégia dos dois passos, tomando como ponto de vista as teses de Marx sobre a anarquia do mercado e o despotismo da fábrica capitalista: ficou-se no primeiro passo, o do planejamento central, enquanto o segundo, o da democracia pela eliminação da subordinação pelo assalariamento, como se sabe, precisou ficar para depois do futuro que nunca chegou.

Creio que poderemos sentir melhor o drama, acompanhando a reconstituição feita por Paulo Singer (Economia socialista, Perseu Abramo) do raciocínio marxista clássico acerca da passagem ao socialismo, resultante da contradição entre a produção social e sua apropriação capitalista privada, ou nos termos políticos de há pouco, o antagonismo entre o despotismo da produção na fábrica individual e a anarquia da produção na sociedade inteira, contradição a partir da qual a teoria explicava a necessidade primeiro da centralização monopolista do capital e daí a irrupção da produção planejada característica da sociedade socialista. Quer dizer, a certa altura desse processo, o Estado, representante oficial da sociedade capitalista teria de assumir finalmente a direção da produção sem se confundir com a mera estatização dos setores produtivos. É nesse momento que a sociedade socialista irrompe, ajustando finalmente, pela regulação social planejada da produção, a natureza social das forças produtivas modernas e sua apropriação aberta e direta pela sociedade. Aqui o ponto nevrálgico de todo o drama, na visão de Paulo Singer que estou acompanhando, por um lado, tudo se passa 
como se o socialismo fosse um desdobramento linear do desenvolvimento capitalista das forças produtivas, por outro lado, a confiança numa espécie de milagre dialético de que uma relação capitalista levada ao extremo se inverte, quer dizer, a propriedade estatal-proletária dos meios de produção, se interverteria abolindo e o proletariado como classe e o Estado como Estado. Sabemos no que deu. Aliás o próprio Lenin, vendo a esperada revolução mundial afastar-se cada vez mais do horizonte próximo, não viu outra solução - que obviamente supunha provisória senão imitar em ritmo de marcha forçada o capitalismo organizado alemão (a expressão é de Hilfending, é bom não esquecer), nossa tarefa, dizia, é fazer ainda mais sistematicamente o que Pedro, o Grande, fez, quando acelerou a cópia da cultura ocidental pela Rússia bárbara, confiando mais uma vez nos milagres da dialética, usar métodos bárbaros na luta contra a barbárie. O resultado não foi brilhante, como sabemos - e isso não é nem jamais será um argumento a favor do capitalismo, além do prejuízo incalculável de converter o marxismo numa ideologia da industrialização retardatária, cujo objetivo pouco ou nada mais tinha a ver com a emancipação da condição proletária, mas convergir com o mesmo nível de riqueza e poder dos Estados do núcleo orgânico da economia capitalista mundial. O colapso final dessa trajetória antissistêmica apenas comprovou seu caráter inerentemente autodestrutivo, decorrente, em última instância, de sua dinâmica imanente ao próprio capitalismo histórico como sistema mundial de concorrência interestados pelo capital circulante global. Hoje já podemos dizer que pelo menos sabemos o que o socialismo não é nem pode voltar a ser.

\section{Recordações da recepção brasileira de Herbert Marcuse*}

1.

Ouvi falar pela primeira vez em Marcurse em 1965, e mesmo assim indiretamente. É preciso esclarecer no entanto que não sou um bom termômetro: estudei e ensino filosofia há 34 anos na Universidade de São Paulo, o que não é uma boa recomendação em matéria de Teoria Crítica. Em primeiro lugar, porque se trata de um Departamento de Filsofoia fundado há meio século por uma missão cultural francesa que se renovou pelo menos até meados dos anos 80 , e como se sabe, antes de 68 Marcuse a rigor inexistia na França, e depois foi barateado na condição de ideólogo do movimento estudantil enquanto durou a temporada gauchista, e assim ofuscado pelo star system local. Num país de cultura reflexa, como era e ainda é a norma em países periféricos como o nosso, era de se esperar que o aprendizado do gosto filosófico acompanhasse as flutuações dos preceitos e preconceitos da metrópole de turno em matéria de cultura letrada. Assim sendo, não haveria mesmo lugar para o hibridismo frankfurtiano no cânone filosófico francês daqueles tempos, no qual só eram admi-

* Depoimento recolhido por Isabel Maria Loureiro e Carlos Eduardo Jordão Machado, na intenção de um eventual leitor alemão, por ocasião do centenário Brecht/Marcuse, Instituto Goethe, SP, junho de 1998. 
tidos historiadores da filosofia e epistemólogos, além de outra variantes subsidiárias da filosofia profissional. Em segundo lugar, porque o ambiente universitário de então, não obstante ser de oposição (primeiro anti-oligárquica; depois de 64 , anti-ditadura militar, obviamente) e majoritariamente de esquerda, além do mais marxizante, era de tal modo construtivo - outro imperativo próprio da periferia, condenada a superar o subdesenvolvimento para não ser rebaixada à condição de nação pária - que se tornara paradoxalmente impermeável à negatividade característica da Teoria Crítica, para os poucos que dela tinham alguma notícia, uma crítica sentimental do capitalismo.

\section{2.}

Como no resto do mundo, a agitação estudantil e seus desdobramentos culturais abriram as portas para Marcuse a partir de 68. Abriram porém as portas erradas. É verdade que não abriram as dos professores, que continuavam a torcer o nariz para aquela filosofia pop. No entanto, mesmo a porta correta do radicalismo dos estudantes rebelados contra o regime militar, abria para um equívoco, que aliás não era apanágio nosso. Também como no resto do mundo, Marcuse - ou o que passava por tal - fora reincorporado à tradição leninista, cujos limites históricos os frankfurtianos foram os primeiros a assinalar, pelo mesmo desde 1937, para não falar do veredicto definitivo no imediato pós-guerra. Ocorre, sublinhando ainda mais o desencontro a que estou me referindo, que a Nova Esquerda brasileira, a caminho da luta armada de inspiração castrista, só rompeu com o etapismo contemporizador da ortodoxia comunista para melhor reatar com o que julga- va ser a teoria e a prática de uma Revolução Proletária a caminho, além do mais anunciada pela provável derrocada do Imperialismo no Vietnã. Tirando este último episódio - a externalização brutal da violência própria de uma sociedade de consumo no seu mais alto grau -, não se poderia estar mais entusiasticamente na contra-mão da letra e do espírito do homem unidimensional, por isso mesmo ofuscado pelas elocubrações de um Régis Debray, para não falar na vulgata hispano-americana de Althusser.

3.

Não faltou quem visse em tamanho desencontro - vinte e tantos anos depois, está claro - uma inesperada convergência, a saber, entre a versão moderada ou realista da Teoria da Dependência (não por acaso a versão que finalmente acabou prevalecendo) e o juízo mais sóbrio de Marcuse acerca do longo fôlego do capitalismo avançado, cuja sobrevida parecia assegurada enquanto continuasse "entregando a mercadoria". Os dependentistas da referida linha hegemônica, por sua vez, mostravam que o mercado interno dos países periféricos estava sendo internacionalizado, que embora dependente, o capitalismo periférico tinha uma dinâmica própria que ainda estava longe de ter dito sua última palavra, contrariando frontalmente as teses estagnacionistas da Nova Esquerda que, convencida da inexorável polarização da economia mundial, resumida pela frase de Gunder Frank acerca do "desenvolvimento do subdesenvolvimento", saira à luta (armada, inclusive) para cortar o nó górdio do dilema: ou socialismo ou regressão sub-capitalista, isto é, fascismo de mercado, como mais tarde o economista Paul Samuelson definiria 
o Chile de Pinochet. Com a devida precaução, seria o caso de dizer que Marcuse e os dependentistas brasileiros somavam pontos desfazendo ilusões à esquerda. Dito isso, trata-se de uma convergência que ninguém viu, além de puramente negativa, em torno de miragens históricas a evitar. É que a rigor a Teoria da Dependência nunca foi propriamente uma Teoria Crítica, na verdade, uma Teoria Tradicional (na acepção frankfurtiana do termo), e por isso mesmo desprovida de qualquer impulso emancipatório, tanto é assim que já se disse das análises dependentistas que não só se desintereressaram de uma crítica radical da civilização capitalista como também, no plano mais próximo do vínculo orgânico com a prática, que elas só não eram compatíveis com as concepções neo-clássicas do comércio internacional como um campo neutro de vantagens comparativas recíprocas, compondo-se, exceto este caso, com qualquer política à esquerda ou à direita, desde que modernizadora e industrializante. Aliás eram os mesmo futuros teóricos da Nova Dependência (não por acaso a constelação intelectual que durante duas décadas engessou a tradição crítica brasileira) que se referiam à Escola de Frankfurt como uma remota lamentação metafísica diante das antinomias da Modernidade.

\section{4.}

Ainda no capítulo dos equívocos - não esqueça o leitor que começamos pelo disparate de uma recepção franco-brasileira -, seria o caso de lembrar que também no Brasil, claro que movido a leituras de segunda mão, se cometeu o desatino de associar Marcuse - que um professor francês do Brasil denominou "um apolíneo encolerizado" - às ma- nifestações locais da Contra-cultura? A ponto de ser confundido - e não só por estas bandas - com os personagens da Califórnia de Edgar Morin. De qualquer modo não deixa de ter a sua graça (acho que só para um brasileiro) ver Marcuse (leitor de Platão e Hegel, derradeiro filósofo da Razão Objetiva) gravitando na órbita da "nova sensibilidade" tropicalista, variante brasileira da pop. E logo o autor de uma das mais abrangentes críticas do capitalismo americano enquanto sociedade fechada e integralmente colonizada pelo brilho repressivo da forma-mercadoria generalizada, a começar pelo sempre-igual pop.

\section{5.}

De qualquer modo essa apropriação indébita (e além do mais pela rama, como lembrei), veio reforçar um estereótipo, em função do qual se costuma periodizar, de uns tempos para cá, a recepção brasileira da Teoria Crítica. Ficou estabelecido que Marcuse tinha sido quando muito página virada no primeiro capítulo daquela recepção arrevesada, quer dizer, mentor de um vago anti-capitalismo romântico, compreensível nos anos de chumbo de resistência à modernização conservadora impulsionada pelos militares, porém francamente deslocado à luz do reencontro do país com o seu destino. Estou me referindo é claro a uma periodização patrocinada pela súbita e larga difusão entre nós da versão habermasiana da evolução (para lugar nenhum) da Escola da Frankfurt. Embora Marcuse não tenha merecido um capítulo especial no Discurso Filosófico da Modernidade, não há dúvida de que também desesperou de encontrar uma centelha de racionalidade não-instrumental no curso nefasto do mundo, e como 
tal foi arquivado por aqui (antes mesmo de ser lido) como precursor do "irracionalismo", nome genérico, no caso dos decalques brasileiros de Habermas, para as patologias nacionais, entre elas o populismo, o nacionalismo, e um suposto multiculturalismo de nascença. Como nunca brilhou no firmamento brasileiro (salvo durante a febre-68, e mesmo assim...), não se pode falar de um eclipse de Marcuse, bem como de um renascimento do interesse por ele. Ou melhor: creio que brevemente estará sendo lido pela primeira vez, enfim.

\section{6.}

Com esse ajustamento harmonioso entre a Teoria da Ação Comunicativa e o atual estágio de ansiedade modernizante da vida ideológica brasileira, podemos dizer que se encerra o desencontro crônico entre a Teoria Crítica e a experiência nacional, desencontro que vitimou, como vimos, a recepção de Marcuse entre nós. A economia mundial deu uma guinada para a direita, um tranco colossal que nos derrubou, reviravolta que não é a primeira em nossa história e sempre contou com ao apoio entusiástico das elites locais, que se preparam mais uma vez para sacrificar outra geração ao mito da ascensão do país aos degraus superiores da vida moderna. Trata-se de uma síndrome recorrente, o sentimento algo subalterno de viver numa país errado, que precisa erradicar suas taras sociais, sair do desvio e entrar finalmente nos eixos da normalidade capitalista pautada pelos países centrais. Que deixa assim de ser criticada e vista ela mesma como uma ameaça à sobrevivência da humanidade. Compreende-se que, nestas condições, mudanças de paradigma são sem- pre bem vindas, sobretudo se destinadas a desbloquear os espíritos na direção da nossa modernidade sempre inconclusa. Portanto, a Grande Recusa não é mesmo conosco, salvo no dia em que se descobrir que o futuro já chegou e é isso mesmo que estamos vendo, desintegração social impulsionada pelo programa suicida da economia mundializada. Quando esta experiência inédita se cristalizar de vez, Marcuse será finalmente compreendido na sua verdadeira dimensão. 


\section{8 trinta anos depois*}

Como o sr. acompanhou os acontecimentos de Maio de 68 ?

Acompanhei 68 na condição de jovem professor de filosofia na faculdade da rua Maria Antônia. Aliás, estreante, maio desabou no meu primeiro semestre de magistério. Contestação naquele clima escolar de acatamento, nem pensar, só mesmo por inércia ou mimetismo. Aliás, contestar o quê? Mesmo as "lideranças", como se dizia, do movimento por uma universidade crítica choviam um pouco no molhado. Com as exceções de praxe, todo mundo era razoavelmente do contra_contra a ditadura militar e o medíocre conservadorismo ambiente que fora despertá-la na modorra das casernas. Porém, a favor dos bons cursos oferecidos, sobretudo se comparados à vida besta das grandes escolas. No caso do meu departamento, por exemplo, os estudantes queriam menos Platão e Bergson e um pouco mais de Marx e Lênin, porém estudados de acordo com os métodos filológicos de sempre. Não quero dizer que o clima fosse ameno em meio ao bate-boca ideológico de sempre. Havia, pelo contrário, muita apreensão, pois a repressão podia baixar a qualquer momento, como de fato aconteceu com o incêndio do nosso prédio e a morte a bala de um estudante.

* Entrevista concedida à Ricardo Musse para a Folha de São Paulo, caderno “Mais!”, 10.05.1998. 
Como o sr. vê hoje o Maio francês?

Seria bom relembrar que 68 abriu quase uma década de lutas sociais e que só foi de fato enterrado pela contra-revolução liberal conservadora. Reagan e Thatcher não se empenhariam tanto em quebrar a espinha de um movimento sindical supostamente morto! A semente da globalização (ou que nome se dê à ditadura dos mercados financeiros sustentada pela retomada fraudulenta da hegemonia americana) foi plantada como resposta à crise de governabilidade (na acepção conservadora da fórmula) desencadeada em 68 (a crise fiscal do Estado não tem apenas raízes econômicas endógenas, o fordismo não explodiu somente em função do seu sucesso). Até mesmo nosso "milagre" periférico tem a ver com a liquidez internacional à procura de uma lucratividade bloqueada nos países centrais; e mesmo o nosso ABC de 1978 em greve pode ser visto em linha com a turbulência da década de 1970 (sindicalismo de combate etc.), talvez mais crucial que os anos 60.Se estas impressões fazem sentido, a famosa adesão sistêmica da força de trabalho, cooptada pelas prestações do Welfare State, precisa ser recontada. Bem como a impressão de que viveríamos novamente (como achava Marcuse em 64, abrindo "O Homem Unidimensional") numa sociedade sem oposição.

Como o sr. compreendeu, na época, os acontecimentos?

Nas condições que acabei de evocar, não dava mesmo para compreender muita coisa. Nossos luminares sociológicos viviam dizendo que aquilo tudo não ia dar em nada, seja em Paris ou nos Brasis, talvez porque assim o desejassem junto com as CGTs da vida. Era moda aliás nos altos escalões do sa- ber mariantonesco desancar o pobre Marcuse _ por falta de rigor, é claro. Grande Recusa não era mesmo conosco: com sorte nos livraríamos da ditadura e trataríamos de arranjar uma saída para o país, pró-sistêmica, já que a anti, queimada pelos soviéticos, só poderia dar em bobagem, para dizer o mínimo. Voltando ao meu zero de compreensão. Simpatizava, mas não via nada. De sorte que, quando o Roberto Schwarz, num ensaio memorável (“Cultura e Política, 1964-69”), recontou o que todos havíamos vivido, fiquei encabulado com a minha miopia na época, agravada pelo nosso horizonte filosofante. Também não era para menos. A síndrome mundial denominada Maio Parisiense de 68 irrompera entre nós num palco por certo ardorosamente oposicionista, cultura de esquerda largamente hegemônica, porém socialmente confinada, pregando para conversos: contestação em recinto fechado (e lotado, como nos festivais de canção ou nos teatros) só podia exasperar mal-entendidos homéricos. É só relembrar o modo subversivo de a Tropicália transformar contracultura em apelo comercial. Ou a nova esquerda requentando palavras de ordem da velha: da arte dita social ao centralismo democrático.

Maio foi o fecho de uma série de revoluções que se iniciaram em 1789 ou teria sido o início de uma nova forma de fazer política?

Se 1789 é o desfecho de uma longa luta entre acumuladores de capital pela acumulação do capital (o absurdo fim em si mesmo de sempre) e não um combate "progressista" entre a "modernidade" e o "atraso" (feudal, no caso), e se, tomando certas liberdades com o período dito de acumulação primitiva, considerarmos que em 1789 fazia pelo menos três séculos que as principais instituições da acumulação interminável, 
característica do capitalismo enquanto sistema histórico, já estavam de pé (da desigual e polarizadora divisão mundial do trabalho à competição interestatal pelos benefícios da acumulação), é no mínimo muito estreita a visão do capitalismo emergindo da transição do Antigo Regime para a nova ordem burguesa etc. Tudo isso para dizer que, nesta linha de raciocínio, 1789 foi um arranjo "sistêmico" entre os mesmos estratos dominantes que três séculos antes conseguiram reverter com sucesso a tendência a um relativo igualitarismo econômico que se anunciava com o desmoronamento da Europa medieval.

Em outras palavras, uma grande convulsão anti-sistêmica como 1968 não pode fazer parte da mesma série inaugurada por 1789. Não por acaso, dando a volta ao mundo, o que começou em 1968 (e não terminou em 68, fogo de palha que não deu em nada), além de antiimperialista se contrapôs também à velha esquerda, que desde a origem alinhara a "revolução proletária" à perspectiva histórica da "revolução burguesa". Ora, quem se contrapõe assim à ideia herdada de "progresso" enquanto matriz cultural legitimadora do capitalismo histórico, está sem dúvida, queira ou não, assinalando que a forma política herdada chegou ao seu limite histórico. A série que culmina em 68 e ali se esgotou principiou com a primeira rebelião anti-sistêmica dos tempos modernos, 1848. A atual desintegração da política enquanto esfera autônoma, hoje engolida pela mercantilização total, significa que a antiga coreografia progressista, o "pas-de-deux" ou "de-trois", reação conservadora, liberalismo (hegemônico) e sua derivação radical, o socialismo, também deixou de balizar a guerra entre acumuladores de dinheiro e poder e as várias classes que vão resvalando (ou se alternando) para o leito comum da alienação e da exploração sem limites.

\section{Marx cult*}

Você escreve liuros, artigos, edita coleções de liuros, orienta trabalhos, participa de discussões que vão do Fórum Social Mundial até grupos de teatro e tem se notabilizado como crítico "feroz" do processo que levou ex-esquerdistas ao poder para configurar a era FHC. Vamos falar sobre a situação do marxismo hoje. Qual nossa conjuntura atual?

Acho que um mapa do marxismo no Brasil hoje deveria começar pelo inventário de alguns disparates bem característicos. Pode parecer piada mas não é, mas acontece que a própria realidade, e na vanguarda o Brasil como sempre, passou a imitar o marxismo. Viramos um abc do marxismo, um gigantesco manual de materialismo histórico. A atual clique governista adora falar em complexidade, são todos profundérrimos, mas ocorre que o tal processo complexíssimo foi brutalmente simplificado, tornou-se escrachadamente economicista, sem o refresco da menor mediação, é tudo direto, sem folga para a menor complicação hermenêutica. Um exemplo de reducionismo explícito, o triste fim do Estado brasileiro.

O que aconteceu?

* Entrevista publicada na revista Cult, SP, setembro de 2002. 
Simplesmente foi afinal reduzido com todas as letras à primitivíssima condição de Comitê Executivo dos negócios comuns dos endinheirados de sempre.

\section{Essa história já conhecemos.}

Elevando um pouco o nível, admitamos que a mancha selvagem do endividamento público parece sair diretamente do imortal capítulo sobre a Acumulação Primitiva. Temos assim um Estado pirateado, inteiramente alienado aos seus novíssimos credores. Como qualquer particular achacado por agiotas e chantagistas, passou a assegurar uma espécie de renda mínima ao capital.

Imensa "bondade" nossa. Um altruísmo de valor inteiramente global... Entendi essa primeira aberração. Passemos à segunda.

Que a realidade brasileira de hoje tenha se tornado um pastiche do marxismo, e um marxismo caluniado, injustamente chamado de vulgar, não é propriamente uma contribuição original nossa...

...afinal estão ai de volta os barões ladrões americanos, as dinastias petroleiras dando golpes de estado $e$ cevando o complexo industrial-militar.

Lembra-se dele?

Anda excitadíssimo hoje em dia...

Pois é. Onde inovamos mesmo, foi na invenção de uma anomalia invulgar, rara em toda a parte, o achado de um marxismo de classe dominante, com perdão do mecanicismo na atribuição de classe...

São os “ares do tempo"...

Sem dúvida. Um marxismo igualmente ultracomplexo, sob medida para a nova classe de operadores no poder, nova casta varietal de professores e financistas-consultores.

\section{Estou me lembrando do filme "O Príncipe"...}

Um belo arranjo: ao brutalismo da realidade simplificada até o osso, veio dar cobertura uma espécie de sofisticação de fachada.

Agora estou lembrando do "Dicionário tucano" do Zé Simão...

Não é difícil confeccionar uma antologia de originais marxistas a favor da modernização capitalista. Assim, nos momentos de alta conjuntura, podem nos vender privatização-pilhagem como desenvolvimento das forças produtivas etc. Na hora da baixa, é a vez dos juízos materialistas implacáveis, sentenças de dialética fulminante derrubando uma a uma todas as falsas superações. Uma divisão do trabalho caída do céu, entre progressismo e funcionalismo metafísico. Cortando pelos dois lados, sempre um Marx teórico avançado do capitalismo vencedor.

Irresistível, nada como entender como ninguém a dinâmica do capitalismo! 
Maravilha de alternância, ora salto participante do marxismo governista, ora meditação desabusada sobre a alma e as formas.

Entendi. Ora o mercado é a consistência lógica da história e o neoliberalismo seu conteúdo de verdade irrefutável; ora, como agora, trata-se de uma criança mimada, com crises de confiança, abalos psicológicos, tensões e soluços especulativos que precisam de remédios e apoio...

E medo, muito medo de qualquer ultrapassagem pós-capitalista, como se além do mercado a vida não fosse possível sem terror.

Terror econômico. Então, nesse cenário de aberrações, o marxismo se encontra em que ponto?

A esses dois disparates, devemos acrescentar um paradoxo sensato. Como acabamos de verificar, o atestado de óbito do marxismo foi passado na hora em que a desgraça econômica do nosso tempo justamente fazia realidade e marxismo correrem um na direção do outro.

O marxismo está morto; então, viva o marxismo!

O problema é que nem sempre sabemos em qual dessas duas menções do marxismo botar aspas. Bom: faz todo o sentido do mundo que a nova esquerda global, sem ter o sal da terra, longe disso aliás, avance atualmente de costas para o marxismo. $\mathrm{E}$ isso na exata medida do seu anticapitalismo sem desconversa. Pela primeira vez, a esquerda não alega mais contar com o curso da história empurrando-a para a frente... ...quem diz isso agora é a nova direita...

...que, em simbiose com o capital, dá a entender que é apenas o porta-voz dos seus feitos ciclópicos, de suas grandes rupturas de vanguarda, e tudo isso arremedando novamente o velho realejo marxista ocidental dos desenganos inapeláveis. Definitivamente, esse teatrinho parece ter chegado ao fim.

O "dia do pagamento final"...

Destruição social hoje não tem mais futuro, não há mágica dialética que a converta no seu contrário. Nas incontáveis utopias militantes de hoje, alimentadas por um novo sentimento de oposição e urgência, capitalismo tornou-se sinônimo de catástrofe, de contrassenso suicida cotidiano, de sorte que não faz mais sentido algum hibernar até que amadureçam condições que novamente permitam medir forças com a besta. Quer dizer, nos seus próprios termos, é um desfecho previsível.

Não é mais esse o jogo.

Não é mais esse o jogo. 


\section{PARTE III}

\author{
ESQUERDA E DIREITA NO ESPELHO DAS \\ ONGS
}

\section{SOFÍSTICA DA ASSIMILAÇÃO}

DOCUMENTOS DE CULTURA, DOCUMENTOS

DE BARBÁRIE

O NOME DO SUJEITO

\section{Esquerdae direita no espelho das ONGs*}

Em princípio, como aliás o próprio nome indica, uma Organização Não-Governamental não pode pensar e agir como uma agência estatal. Tampouco falar a mesma língua. E, no entanto, parece estar ocorrendo um formidável disparate - pelo menos aos olhos de um leigo. De uns tempos para cá, autoridades governamentais desandaram a gesticular e arengar como se fossem militantes de uma ONG de todas as ONGs, misteriosamente eleitos pela mão invisível do destino para advogar a boa causa da sociedade, ocupando, porém, graças sabe-se lá a que manobras astuciosas da razão, postos chaves no aparelho de Estado, sobretudo os diretamente concernidos por uma enteléquia cívica denominada "o social". Ato contínuo, têm se dedicado a lançar "programas" de fortalecimento da "sociedade civil", como se esta fosse uma área de fomento, e, pelo visto, em promoção. É um tal de abrir e construir "espaços", nos quais "interagem" "atores" (novos, de preferência) que trocam juras de "compromisso" e "envolvimento" mútuos, tudo num registro altamente "proativo". Em contrapartida, será taxada de "reativa" qualquer iniciativa que cheire a ressentimento de perdedor. Espaços obviamente de "participação", e mais enfaticamente, de "participação cidadã", irrigados por "canais de interlocução", através dos quais governo e a supracitada sociedade civil "aprendem a pensar e agir juntos", constroem pla-

* Publicado nos Cadernos ABONG, n.27, maio de 2000. Posteriormente incluído no livro Zero à Esquerda, ed. Conrad 2004. 
taformas para futuras "parcerias" e novas "interações”, conferem "visibilidade" a iniciativas "emergentes", promovem a "cidadania ativa". "Parcerias felizes" enfim, e a tal ponto superlativas que a "sinergia" que as multiplica é dessas que extrai 22 de um simples 2+2, ao contrário de um medíocre e "reativo" 4. Para quem orbita nesses espaços de alta densidade moral, tudo é "desafio": miséria, violência, fome, desemprego, etc. Desgraçadamente coisas de não, como diria o poeta, na verdade efeitos colaterais produzidos pelo forte "impacto" das "novas realidades". O maior "desafio", porém, é a "incorporação da cidadania", a "defesa e promoção dos direitos". Reforma do Estado? Administração Pública "gerencial"? Com certeza, desde que "voltada para a cidadania". Quer dizer, mais uma vez, destinada ao fortalecimento de uma "sociedade civil eticamente estruturada", além do mais, em vias de se tornar planetária. E assim por diante. No limite, não há nada que não exija aspas, ou - imaginando uma futura organização do pensamento não-governamental - que não deva ser dito como quem cita.

Espero não estar cometendo de saída uma injustiça ao incluir sem mais ONGs - noves fora, é claro, as espúrias e apócrifas - na mesma comunidade de fala, para empregar a expressão favorita dos adeptos do novo "paradigma", o da comunicação, que em princípio teria ocupado o lugar vazio deixado pela falência dos anteriores, ditos de transformação social. Sobretudo levando-se em conta esse jargão untuoso e adocicado no qual se derramam as efusões cívicas dos governantes e suas ramificações bem falantes, enternecidos com a benfazeja revelação de uma sociedade dita civil porque finalmente deixou de ser "reativa" - coisa compreensível nos tempos de arrocho militar - quer dizer apenas "denunciadora e reivindicativa", nas palavras de uma grande dama patronnesse. Não obstante, fica assim mesmo a impressão de um amistoso compadrio vocabular, como se ONGs e governo formassem um bizarro sistema de vasos comunicantes, pelos quais circula o mesmo léxico dos Direitos, da Cidadania, da Esfera pública, da Sociedade civil etc., ora barateado pela ênfase edificante e nem sempre oficial, ora no diapasão dos antigos ou ainda novos Movimentos Sociais, que era o da interpelação de um poder usurpador, a um tempo ausente e opressivo. Em suma, ora à esquerda, ora à direita, o que se ouve mais parece uma língua geral, verdade que condenada à usura inevitável dos automatismos. Como desarmá-los, e dar o nome certo à coisa certa?

Não governamentais e além do mais sem fins lucrativos. Tão longe portanto do dinheiro quanto do poder? Outra vez por definição, é claro que sim. E novamente nos deparamos com um disparate de mesmo teor. É que também as empresas, por uma espécie de esquizofrenia programada, principiaram a se comportar em público como se fossem de verdade organizações não-lucrativas! No fundo, se ainda distribuem dividendos para os seus acionistas é por mera e incontrolável decorrência técnica de sua maior eficácia no uso de bens escassos. Em primeiro lugar viriam os incontornáveis direitos da cidadania - como seria de se esperar dessas verdadeiras centrais de recursos à disposição da sociedade. Uma empresa digna do nome precisa antes de tudo se distinguir das demais por uma autêntica fome de transcendência. Essa a experiência fundadora de toda "vivência empresarial", uma ânsia de superação permanente que não recua diante de nenhum risco no afã de 
superar sua desculpável vocação um tanto filistina para o lucro e outras inclinações aquisitivas. Daí a crescente "cumplicidade", o alto grau de "envolvimento com o seu entorno", observáveis hoje em dia no meio empresarial. Não sendo assim um fim em si mesmo, a empresa se encontra no mercado - para o qual se haverá de encontrar sem dúvida outro nome mais condizente com essa visão cidadã do mundo - rodeada de "parceiros" e de "interlocutores", com os quais por certo "interage" de um modo "proativo". Também por aqui tudo é "desafio" e motivo para "compromissos" renovados com os valores intangíveis da "interação simbólica" característica de uma "empresa-cidadã". Nesta entidade surrealista nada acontece que não seja emanação de uma intensa atividade "comunicacional", que não se dê sob a égide do "consenso" e da "transparência". Enfim, management e direitos de última geração correm um para os braços do outro.

Como se pode notar, aliás sem nenhuma surpresa, trata-se do mesmíssimo palavrório das famigeradas reformas gerenciais do Estado em nome de novos direitos ditos republicanos da "cidadania" etc., etc. Sem falar no foguetório de clichês das campanhas cívicas de "marketing social" - como as empresas costumam designar essa nova fronteira de negócios. Só que agora a contaminação recíproca entre as palavras e as coisas tornou-se ainda mais acintosa do que no caso anterior, no qual o pastiche vocabular parece ocorrer exclusivamente por conta do Estado. Admitido é claro, ainda no plano do quiproquó, que a linguagem, outrora interpelativa, dos direitos da cidadania seja menos incongruente na fala atualizada com que uma irmã de caridade se refere ao sentido de suas obras humanitárias, do que nas alegações arrevesadas do governo acerca do incremento da chamada participação cidadã na terceirização das funções sociais do Estado - o que não deixa de ser um paradoxo histórico. Já no mundo sem-fins-lucrativos, entretanto, o mimetismo terminológico, sendo recíproco, se apresenta na forma de uma convergência não menos surpreendente. Enquanto as firmas tagarelam na autodesignada condição de novíssimos pioneiros e protagonistas da Era dos Direitos, os detentores senão dos direitos autorais dessa matriz discursiva, com certeza de sua disseminação mais combativa, acabaram descobrindo nessa arena, conflitiva por natureza, por assim dizer uma vocação profissional.

Com perdão da má palavra, o fato é que também existe um mercado atraente para as iniciativas cidadãs. Ocorre simplesmente que a mais estrita observância da cláusula sem-fins-lucrativos não é uma barreira à entrada no mundo dos negócios, podendo até representar uma senha privilegiada de ingresso. Segundo consta, a paulatina impregnação pelos usos e costumes da livre iniciativa começa pela inocente elaboração e execução de um "projeto" em conformidade com as exigências de qualquer agência financiadora. Tais projetos lidam com fundos escassos sob severa vigilância, que por sua vez não toleram amadorismo, antes exigem pelo contrário um cálculo profissional de custo/benefício, na previsão do "retorno" do investimento, o qual vem a ser enfim a transformação do apoio recebido em serviço. Submetido por seu turno à concorrência do programa similar oferecido por outra entidade, que também disputa "parcerias" e nichos em "mercados sociais inovadores", o advogado voluntário dos direitos dos sem direitos, sob pena de não produzir o "impacto" que dele se espera, logo estará falando, por exemplo, em "público-alvo" e afinal recorrendo a todos os expedientes consagrados do gerenciamento dito estratégico. Não cus- 
ta lembrar: "estratégia" é sempre uma manobra de guerra "contra" um rival. Sem falar que tudo isto dá emprego, e muito. (Nada contra, por favor). De sorte que nem sempre é fácil perceber onde termina a utopia republicana e principia um empreendimento tocado à imagem e semelhança do mundo dos negócios. Aliás a fraseologia gerencial-cidadã também está aí para atenuar qualquer eventual excesso de zelo: uma linguagem comum aos dois "setores" é o melhor atestado da "interação positiva" entre essas duas ânsias que porventura rasguem o peito inquieto do ativista social.

Não faltam ressalvas. Não há como não conceder aos teóricos do Terceiro Setor que, de fato, numa economia de mercado não há valor de uso coletivo que, ao se tornar objeto de uma demanda efetiva, não gere um correspondente investimento lucrativo. Também se pode admitir que se não estivesse pressuposta a inquestionável normalidade do lucro privado, uma organização social denominada "sem fins lucrativos" não faria o menor sentido. Acontece que faz, e muito - desde, é claro, que o retorno de um investimento dito cidadão não seja negativo. Preenchida esta cláusula do mais corriqueiro cálculo econômico - prossegue o argumento - o que conta mesmo num tal retorno cidadão é a sua "eficácia simbólica", devidamente realçada por um aparato retórico condizente com o atual estágio da reprodução social.

Está claro que a carga simbólica que imprime uma "aura positiva" às ações voluntárias sem fins lucrati- $\operatorname{vos}^{1}$ não decorre apenas da inegável funcionalidade delas na legitimação das políticas sociais compensatórias recomendadas pelos próprios patrocinadores da devastação econômica em andamento. Tampouco, como quer o discurso edificante corrente, derivaria da pressão moral exercida sobre os agentes econômicos para que se sintam concernidos pela "nova cultura de participação cidadã", como se diz na língua geral do momento. (Voltaremos ao paradoxo da compulsão à benevolência civil numa era de narcisismo de massa). Como ficou dito pelos próprios interessados, é preciso que este suplemento espiritual tenha um significado econômico tangível. E se possível crescente, pelo menos até o ponto ótimo em que se reinventea roda da acumulação-a saber, que ela sempre foi e continuará impura, que a valorização do capital emperra se não encontra à sua disposição uma massa adequada de bens e serviços produtivos fora do mercado -, claro que nos termos eufemísticos exigidos pelo Terceiro Setor. Até mesmo o mais empedernido fundamentalista do mercado haverá de convir que os investimentos propriamente ditos estarão comprometidos sem uma dose correspondente de investimentos ditos sem fim lucrativos, por certo mediante conveniente dedução do desembolso ético. Compreende-se assim que se exija eficácia gerencial dos eventuais "parceiros" selecionados na "sociedade civil", e também que este palavreado valha o ouro cuja extração eleva o usuário ao reino dos fins. Ainda mais num momento em que o novo padrão de financiamento mundial da economia

1. Na fórmula oportuna de Rubem César Fernandes, muito atento, e logo se verá porque, aos "deslocamentos simbólicos" que acompanham o atual protagonismo dos "novos atores" que atuam no Terceiro Setor (cf. Privado porém Público - o Terceiro Setor na América Latina, Rio de Janeiro, Civicus-Relume-Dumará, 2.ed., 1994, p.33. 
impõe um regime de subcontratação múltipla de funções que o Estado não considera mais exclusivas suas. Assim sendo, algumas observações acerca desse novo regime de expansão da famigerada esfera pública não-estatal talvez ajudem a compreender um pouco melhor as vantagens comparativas simbólicas de uma organização não-governamental e não-lucrativa das energias cívicas das pessoas privadas.

Na perspectiva dos novos donos do mundo-fiéis servidores de um sistema que justamente por ser cego encarna a própria dominação, e por isso mesmo funciona sempre a favor dos dominantes de turno - a reestruturação gerencial do Estado, desencadeada pela privatização inapelável de todas as funções nas quais não demonstra dispor de uma vantagem comparativa relevante, nada tem a ver com a fantasia paleoliberal de um governo reduzido ao mínimo denominador de sua vocação coercitiva e garantidora do bom andamento dos negócios privados, de resto sempre reafirmada em qualquer circunstância histórica. A primazia absoluta dos mercados requer, ao contrário, um Estado forte: no jargão do Banco Mundial, um Estado atuante, não mais um provedor, porém um "parceiro" facilitador e regulador. Quer dizer²: trata-se de fato de um Estado mais forte do que nunca, na medida em que lhe cabe gerir e legitimar no espaço nacional as exigências do capitalismo global; assim, a força do Estado, que no período de compromisso keynesiano consistiu na sua capacidade de promover regulações e prestações não mercantis, converteu-se numa outra, o poder de submeter as nor-

2. Na boa tradução de Boaventura de Souza Santos, “A reinvenção solidária e participativa do Estado", paper apresentado no Seminário "Sociedade e Reforma do Estado", São Paulo, maio de 1997. mas da reprodução social à lógica do dinheiro, coisa que o mercado por si só está longe de poder fazer sem correr o risco da ingovernabilidade. Restaria então verificar qual destino esse novo Estado indutor-normativo-regulador-facilitador (e brevemente, de novo "desenvolvimentista", por que não?, numa era cujo nominalismo permite dizer qualquer coisa, ainda mais no país clássico das "coisas trocadas") reserva às populações descartáveis e por isso mesmo cada vez mais carecidas dos serviços públicos essenciais, perdão, o público-alvo do envolvimento ético com o amparo à exclusão social. Ocorre que só um Estado gerencialmente reformado pode se tornar um eficiente parceiro-facilitador da acumulação privada, em particular nos elos das cadeias produtivas mundiais que porventura hospede e remunere, e assim sendo ${ }^{3}$ se "envolverá" prioritariamente ("eticamente", melhor dizendo, pois afinal estará lidando com empresas-cidadãs) na seleção e hierarquização dos agentes não-governamentais que, por subcontratação política, adquirem concessões do poder estatal e se lançam na conquista do espaço-público, desertado por sua vez por um Estado cuja capacidade de regulação social parece ter enfim se esgotado, mas não o poder organizacional, ou mais propriamente, poder estratégico-gerencial (e é em torno desse poder que se travam as lutas políticas de hoje) de promover a concorrência entre os serviços públicos (como se dizia antigamente), descentralizados por contratos de gestão, mais preocupados portanto, tais "serviços", com objetivos e "resultados", em obter recursos e não em despende-los (embora não se trate de produção mas de serviço): quanto aos usuários, serão tratados como clientes se forem solventes. Aqui o lugar

3. Voltando à "tradução" de Boaventura de Souza Santos. 
de um Terceiro Setor gerencialmente enxuto. Um Estado parceiro-facilitador deve "estrategicamente" se retirar assim que organizações não-governamentais "demonstrarem" a superioridade de suas vantagens comparativas - convenhamos, uma vitória sem muito esforço já que não havia mais em campo com quem competir, salvo a sucata preparada para tal efeito demonstrativo.

Vejamos outro caso de eficácia simbólica benigna. Não há mais executivos de Desenvolvimento Social das grandes corporações de negócios - como de resto o nome destes novos departamentos de $\mathrm{P} \& \mathrm{D}$ já indica - que duvidem do benéfico isomorfismo entre entidades com e sem fins lucrativos: afinal empresa e ONGs não são “organizações sociais" muito semelhantes? E quando empregam a expressão "organização social" sabem muito bem do que estão falando, pouco importa a maior ou menor convicção com que giram a manivela do realejo "cidadão". A fórmula mágica "organização social" designa um curioso espécime da zoologia fantástica gerencial, algo como uma ONG clonada nas incubadoras do Estado, uma sorte de ONG espelho da similar produzida por geração espontânea no seio generoso da sociedade dita atualmente civil. Mais exatamente, segundo a nomenclatura oficial, organizações sociais resultam da transformação dos serviços públicos em entidades públicas de direito privado que celebram com o estado um contrato de gestão, cujas atividades são controladas de forma mista pelo Estado (financiamento parcial pelo orçamento público, poder de veto e cooptação nos conselhos de administração) e pelo Mercado (cobrança de serviços prestados pela mão invisível da concorrência entre as entidades). A essa metamorfose, e correspondente simbiose entre poder e dinheiro deu-se o nome de "publicização" - outra palavra vitimada pela implosão semântica do léxico dos "direitos da cidadania”, que logo trataremos de observar mais de perto. Como se trata obviamente de um processo de "publicização" destinado a ampliar ainda mais o "espaço de participação cidadã" com a introdução de novos "atores emergentes" - de cujas "habilidades gerenciais" e "visão estratégica" redundará por certo um bem-vindo empowerment ("empoderamento" em português) da "cidadania" numa sociedade de "baixa participação" como a nossa -, não se poderá dizer que se está "privatizando" o que quer que seja. Pelo contrário, somando vantagens dos dois lados, estará por acréscimo nos livrando do modo de pensar dicotômico que nos prendeu na armadilha maniqueísta do "ou bem estatal, ou bem privado". Conclusão: "eis aí algo de novo que pode dar certo. Na verdade, essas organizações sociais de caráter público constituem uma espécie de ONG de novo tipo, nascidas do Estado e não da sociedade, com forte apoio estatal e participação da sociedade civil"4 . - Já deu para reparar, antecipando o argumento, que o sentido do novo léxico nem sempre se revela à primeira leitura, pois se o discurso não é mais explicitamente o dos direitos, como exigiria pelo menos a letra da Constituição, tampouco é chapadamente o dos serviços e assemelhados. Afinal se trata de um sistema de simulacros. Assim, a fraseologia dos direitos, que não precisa ser liberal (longe disso), carrega, como se sabe, toda a reforma gerencial do Estado, na qual se trava então o bom combate da última geração de direitos - os “republicanos": e lá se vai outra palavra pelo ralo do redemoinho semântico - contra o populismo corporativo dos burocratas e seus clientes etc. É assim um direito de Quarta geração que alimenta o mito de um Estado-ONG,

4. Herbert José de Souza, FSP, 12.09.95. O Ministro ficou, é claro, sensibilizado. 
a saber o "direito ao patrimônio público", seja ele histórico-cultural ou econômico, e do qual os atuais governantes deram uma interpretação positiva estrita, financiando com fundos públicos a compra das estatais por multinacionais incompetentes, socorrendo bancos falidos para proteger grandes depositantes anônimos, subsidiando a compra de dólares para os que especulam com o câmbio ${ }^{5}$, e outras iniciativas cidadãs de defesa da res publica contra os livre-atiradores patrimonialistas.

Digamos que os "custos de transação" - como se diz no jargão contábil da nova economia institucional preconizada pelas repartições multilaterais de Washington - da atual reestruturação produtiva com financeirização da riqueza, responsável pelo surgimento de uma nova classe de credores profissionais, e crescente iniquidade social, têm sido eficazmente amortizados por essa surrealista troca simbólica entre os "três setores" de uma sociedade integralmente produtora de mercadorias, sendo que as imateriais são as que mais rendem, sobretudo o conforto imaginário de uma integração social puramente virtual. Três setores, a saber: os dois subsistemas estruturados pelo funcionamento supostamente neutro e impessoal dos meios poder e dinheiro, e o vasto Mundo da Vida em que floresce o gosto pela sociabilidade, de que tanto carece o ambiente competitivo do novo cenário econômico. Já deu para notar que essas transfusões entre poder, dinheiro e cultura associativa não seriam simbólica e materialmente funcionais se não houvesse um nítido "contraste normativo"6 entre os valores comuns aos dois primeiros

5. No resumo bem resumido de Fernando Haddad, FSP, 19.04.99.

6. Mais uma vez uma expressão bem encaixada de Rubem César Fernandes, op.cit., p.23. subsistemas e o Terceiro Setor, que por isso mesmo pode se apresentar como o portador da promessa de uma bem próxima harmonia das esferas, a integração possível e desejável de Estado, Mercado e Sociedade Civil. Enfim, uma regulação moral da reprodução social. Dessa miragem dá notícia a Teoria da Ação Comunicativa, que acabamos de pastichar linhas acima, ou por outra, que vem ela mesma glosando espontaneamente o advento do admirável mundo novo da Sociedade Civil, também redescoberta não por acaso nos mesmos termos da apologética corrente, expurgada de qualquer conotação que remeta à sua acepção materialista original, um asséptico "núcleo institucional formado por associações e organizações livres, não estatais e não econômicas, as quais ancoram as estruturas de comunicação da esfera pública nos componentes sociais do mundo de vida"7. Não está só nesta fantasia, à que se presta à revelia um conceito - doravante imprestável que remonta aos primórdios da era burguesa, outro caso notável de torção semântica irrecuperável. Assim, Peter Drucker por exemplo, o profeta das "novas realidades" renascentistas do capitalismo global - entre seus prognósticos estava a previsão de que as corporações transnacionais, que simplesmente reintroduziram os baixos salários como fator de competição nas cadeias globais, se encarregariam das políticas de welfare abandonadas com o desmonte anunciado do Estado Social - também é autor de um livro - texto sobre a Administração de Organizações sem fins lucrativos ${ }^{8}$, pelo qual ficamos sabendo que a "sociedade civil", estando composta por entidades

7. Jürgen Habermas, Direito e Democracia, Rio de Janeiro, Tempo Brasileiro, 1997, vol. 2, p.99.

8. São Paulo, Pioneira, 1995. 
não-governamentais sem fins lucrativos, só pode ter objetivo nada menos que a transformação do ser humano. De metamorfose em transfiguração, a sociedade civil acabou se revelando na apoteose do Terceiro Setor: simplesmente, sem tirar nem por, ela é o Terceiro Setor. ${ }^{9}$

Vimos páginas atrás que as grandes empresas estão passando nos últimos tempos por uma espécie de surto esquizofrênico, pois agem, mas sobretudo falam, dando a entender que no fundo são organizações sociais sem fins lucrativos, que aspiram de todo o coração à "zona sideral da total abnegação"10. Esquizofrenia dupla, como também se viu, já que a "cidadania" livremente associada nesta outra zona sideral em que se converteu a Sociedade Civil, não resiste à ânsia pragmática de "puxar pela fibra

9. Cf. Ignacy Sachs, "O desenvolvimento enquanto apropriação dos direitos humanos”, Estudos Avançados n.33, IEA-USP, 1998.

10. Não custa imaginar uma encenação da Santa Joana dos Matadouros, de Bertolt Brecht, recheada com alguns cacos do novo jargão da autenticidade gerencial. Sendo a organização dos Boinas Pretas uma charity, aliás pioneira, não se poderá negar à Joana Dark a condição de voluntária do Terceiro Setor. Por sua vez, o magnata da carne enlatada, Pedro Paulo Bocarra, no início da peça, ainda se encontra no patamar mais baixo da cultura empresarial, a etapa inferior do business as usual. Neste estágio primitivo, em que se comporta de modo reativo na praça de Chicago, ainda não se pode esperar que saiba "lidar com a sociedade civil". Desse aprendizado se encarregará Joana, sabendo que este "desafio" requer dos "parceiros" uma verdadeira "reengenharia das percepções”. Por isso vai procurá-lo, e em pleno pregão da Bolsa abrirá um primeiro "canal de interlocução", não esmorecendo até convencê-lo a adotar uma posição "pró-ativa" diante (outra vez) dos "desafios" que a globalização apresenta à "humanidade ativa". A peça culmina em uma epifania de iniciativas privadas com sentido público. Não sem dilaceramentos, como no último lamento de Bocarra: "Ah! Meu próprio peito inquieto/E rasgado em duas ânsias/Como que por um punhal/Quero a zona sideral/Da total abnegação/Mas a outra ânsia puxa/Pela fibra comercial”, trad. De Roberto Schwarz, Brecht, Teatro Completo, São Paulo, Paz e Terra, vol.4, p.127. comercial", entoando em surdina o coro gerencial. Não se tem notícia, porém, de que altos executivos estejam rasgando dinheiro e tomando água quente. Está claro então que se trata de um sintoma esquizoide benigno. Mas não apenas no sentido filistino de estimular a abertura de institutos que desinteressadamente vendam programas de comportamento ético às "classes produtoras", como se dizia no tempo dos afonsinhos. Até porque as grandes corporações, assim como internalizaram a ciência como fator de produção, na forma de fluxos contínuos de inovação tecnológica, também dispõem - como se presumiu - de departamentos de pesquisa e desenvolvimento, digamos, de valores da cidadania e produtos conexos, enfim parâmetros para medir o valor social de uma firma, cotado em bolsas intangíveis, como por exemplo o "seguro-reputação”. Desnecessário lembrar que estamos em pleno negócio de imagens. Tanto mais prósperos quanto mais assustadoramente ronda o espectro do encalhe e a necessidade de encurtar drasticamente o tempo de rotação dos capitais empatados. De resto, nada mais compreensível que num período histórico que se considera a si mesmo uma Era dos Direitos, além do mais em expansão, os chamados direitos da cidadania se apresentem com o valor agregado à imagem da empresa, destinado a reforçar comportamentos de fidelidade a produtos e marcas. Nada mais do que simulacros, sem dúvida, como se exige de negócios neste ramo em que a visibilidade é tudo. Como tentaremos verificar noutra ocasião, depois de se localizar a matriz prática dessa fraseologia gerencial-cidadã que irriga tanto a estratégia das empresas, quanto as funções facilitadoras da acumulação no Estado-rede, e sobretudo o cérebro dos ativistas de boa-vontade, não seria surpresa se o reencontrássemos na indústria cultural pós-fordista, 
em cujos produtos imateriais já é quase impossível discernir, num mesmo agregado ideológico, o que é valor a ser realizado, o que é custo publicitário.

Voltando à cohabitação das duas ânsias que está nos intrigando, notemos que mesmo a apologética mais exigente não vê incompatibilidade alguma entre a gratuidade do dom de si, característica não só da ação benévola como também do charity business, e a lógica mercantil. Ao contrário, encara essa convergência de um par historicamente antitético como a prova dos nove dos tempos democráticos de hoje, a utopia da autoabsorção narcísica própria do confronto concorrencial se resolvendo milagrosamente na coreografia da solidariedade. A explicação mais uma vez reside na poção mágica da demanda por gratificações simbólicas da parte de indivíduos hipermodernos liberados da tutela rigorista da finada normalização burguesa: convenhamos que numa sociedade dualista, a ressurreição do engajamento como um estilo de vida terapêutico e identitário, um engajamento indolor, por assim dizer, não deixa de ser um achado estratégico, antes de vir a ser objeto de louvação culturalista ${ }^{11}$. Não é menos verdade, porém, que essa estilização encontra forte apoio na experiência, justamente a experiência direta do programa suicida da economia autonomizada como um absurdo circuito fechado: "todos sabem que sua ação é destrutiva, mas todos mantém os olhos vidrados nos rendimentos, assim como o coelho na serpente"12. Mesma interiorização dessa demência objetiva do lado da personalidade ideológica dividida: espera-se que a corrida implacável ao corte

11. Cf. Gilles Lipovetsky, Le crépuscule du devoir, Paris Gallimard, 1992, p.149-150.

12. Robert Kurz, Os últimos combates, Petrópolis, Vozes, 1997, p.188. de custos e pessoal seja conduzida com a unção de almas sideradas pelo bem comum. O surrealismo da empresa que não visa lucro, mas se interessa exclusivamente pelo retorno ético da cidadania como novíssimo fator de produção, responde a essa esquizofrenia de base de um mundo inteiramente racionalizado pela economia monetária, e por isso mesmo sem saída. Porta de fuga que um dia o socialismo prometera abrir. Nesse sentido é que também se pode voltar a dizer que o hibridismo das organizações do Terceiro Setor caiu do céu - verdade que do céu dos velhos dilemas ideológicos, para o chão de um novo "fanatismo setorial”, nas palavras de um nostálgico dos bons tempos da guerra fria ${ }^{13}$. É que a saída de cena do socialismo tornou evidente, entre tantas outras verificações cruciais, que ele não era apenas um "modelo" equivocado ou irrealista - como se a loucura privatista fosse a encarnação mesma do realismo -, mas também uma "espécie de filtro moral sem o qual a civilização moderna revela-se totalmente incapaz de existir; privada desse filtro, a economia de mercado sufoca em sua própria imundície". ${ }^{14} \mathrm{Um}$ filtro político-semântico também, como logo veremos, na ausência do qual esse mesmo fim de linha civilizacional não encontra mais as palavras que lhe descubram o engodo para além da fraude vocabular que acabamos de repertoriar.

13. Roberto Campos, “A Sociedade Civil”, FSP, 18.04.99.

14. Robert Kurz, op.cit., p.145. 
Até aqui não disse nada que o militante de uma ONG de verdade não saiba, e muito melhor do que eu. E por isso mesmo estará melhor qualificado para nuançar ou simplesmente rechaçar essa impressão talvez injusta de "pensamento único".

Mesmo sendo coisa sabida, gostaria de relembrar um pouco da circunstância histórica do desembarque da sigla ONG - constante da nomenclatura das representações nas Nações Unidas - no vocabulário social latino-americano e brasileiro, em particular. Sem o que minha sensação de incongruência poderia parecer mero preconceito. Como se há de recordar, nalgum momento dos anos 70, o novo ímpeto dos chamados movimentos sociais, então em plena ascensão, cruzou o caminho de micro organizações internacionais de cooperação, cujo ânimo prestativo bem ao feitio do clima de reconstrução mundial característico do imediato pós-guerra, estava aos poucos se deixando contagiar pelo espírito militante das campanhas internacionais em favor dos direitos humanos. Ninguém ignora que o principal interessado e provedor daquelas iniciativas eram os Estados Unidos, empenhados num fogo de barragem ideológico preparatório da Segunda Guerra Fria a caminho. Sobreveio, no entanto, uma reviravolta singular. Emanando dos civilizados países centrais, projetou-se uma luz insuspeita de propaganda subversiva adversa sobre as barbaridades praticadas pelas ditaduras do Cone Sul, além do mais com a regularidade de uma política de Estado. Tendo este último, por sua vez, se retirado de cena como instância pública com alguma legitimidade - salvo a exibição tecnocrática dos índices de crescimento econômico -, embora permanecesse brutalmente onipresente como aparato repressivo incontrastável, compreende-se que a esquerda, escaldada inclusive pelo trágico desfecho da luta armada, tenha descoberto que também havia política e transformação possível para além dos confrontos autorizados no âmbito dos aparelhos de Estado. No mesmo passo, a independência daquelas antenas internacionais em relação aos governos metropolitanos coniventes com a repressão local, permitia que um tal arquipélago associativo ainda algo remoto fosse aos poucos se convertendo num valioso canal alternativo numa hora de fechamento político total. Acresce que os agentes responsáveis por modestas intervenções pontuais de "desenvolvimento e promoção social" (na linguagem protocolar dos organismos multilaterais) também foram fazendo, por seu lado, a experiência direta do caráter destrutivo que podiam assumir os processos de modernização na periferia, verdade que registrada nos termos aparentemente mais estreitos dos direitos violados, quando não simplesmente inexistentes ou sequer imaginados. Digamos que a este choque imaginário vivido por uma sensibilidade cosmopolita, tenha correspondido uma concomitante mutação no discurso e na prática dos movimentos populares, que estavam por sua vez reagindo igualmente às segregações modernas, que tinham vindo se juntar às do ciclo anterior, sem falar no museu vivo das antigas taras coloniais. Com algum otimismo se poderia afirmar que o fiasco do populismo finalmente lhes ensinara a não trocar mais direitos por favores - como está ocorrendo de novo com a atual globalização dependente, só que vários degraus abaixo rumo ao fundo do poço. Seja como for, o fato é que algo como uma contestação inédita parecia estar abrindo caminho - não sem dificuldade, se lembrarmos dos tabus da velha esquerda -, sobretudo pelo inusitado das significações mobilizadas, gravitando na órbita de valores imateriais, ou pelo menos sem conexão imediata com o 
núcleo produtivo duro dos conflitos distributivos, como justiça, direitos, autonomia, identidade etc. Assim sendo, não surpreende que a aclimatação da sigla ONG tenha em grande medida cristalizado em torno de imagens de inconformidade, imantada por uma lógica política dissonante, identificada noutra chave com o vasto mundo dos espezinhados pelo novo establishment. Pelo contrário, o que surpreende mesmo - à luz desta rememoração sumária do caráter antagônico original da interpelação pública em nome de direitos e de tudo o mais que daí decorra, não diria a sua metamorfose, longe disso, é a reversão histórica que a tornou indiscernível do seu oposto oficial, descartada é claro a hipótese de uma conversão libertária dos donos do poder e do dinheiro.

Mas o que de fato sabe muito bem o ativista social de uma ONG realmente afinada com suas origens históricas? Sabe por experiência própria que no outro campo, a coalizão dos dominantes globais, quando não busca descaradamente a cooptação pura e simples, se encarniça na destruição sistemática de todo e qualquer coletivo que se organize na defesa de direitos ou na promoção da "cidadania ativa", na desqualificação e desautorização de "espaços públicos" efetivos de representação e negociação. ${ }^{15} \mathrm{E}$ como se isso não fosse bastante, vive-se o grande desconcerto de verificar a cada rodada que tamanha demolição é conduzida nos termos mesmos em que se formula a resistência dos perdedores, os esbulhados de sempre agora na companhia do novos inúteis para o mundo. Portanto, "sociedade ci-

15. Sílvio Caccia Bava, "As ONGs e a nova conjuntura democrática", Boletim ABONG. vil" desmantelada em seu próprio nome, destituição de direitos em nome de direitos de última geração, banalização da injustiça social em função de riscos ditos sistêmicos e compartilhados. E por aí afora. Como se viu, fala-se a rigor a mesma língua - daí o incômodo recurso às aspas de precaução - e, no entanto, o desentendimento não poderia ser maior. À vista do atual cenário de devastação que o Partido da Ordem vai deixando no seu rastro, fica difícil não pensar que até a cooperação eventual, quando ocorre, só pode se dar por equívoco. Convergência antagônica? Pode até ser, mas nem por isso menos desnorteante. Daí também a permanente disputa acerca do sentido das palavras, em torno do qual se concentra boa parte da luta política. Não é para menos: de uma hora para a outra "direito" tornou-se privilégio, além do mais em detrimento dos "excluídos"; sujeito de direitos, usuário de serviços; destruição social virou sinônimo progressista de "reforma"; previdência social, um mal-entendido num país de imprevidentes crônicos; sindicalismo, crispação corporativista; "cidadania”, mera participação numa comunidade qualquer; "solidariedade", filantropia, é claro; bem público, interesses agregados de grupos sociais; desempregado, indivíduo de baixa empregabilidade; "parceria", sempre que a iniciativa privada então com a iniciativa e o poder público com os fundos, etc. De fato, um "espantoso deslizamento semântico"16 - e a ele voltaremos mais adiante. Por agora reparemos - com perdão da insistência - que esse mundo realmente de ponta-cabeça não obstante é palco de batalhas de interpretação justamente porque os contendores estão empregando as mesmas palavras: se acrescentarmos que com sentidos opostos, estaremos

16. Vera da Silva Telles, "No fio da navalha", paper Polis, fev-maio, 1998. 
apenas constatando que então o pastiche objetivo da saudosa Dialética - outrora a lógica mesma da emancipação - afinal se completou. Pois então: o novo acervo de noções normativas comuns aos dois campos que se defrontam, alternando implicação mútua e pressão desagregadora sobre os de baixo, permite que o polo dominante - para dar um nome antigo à expressão atual das "classes confortáveis" - se faça literalmente de desentendido, no caso, quanto à referência dos termos cujo sentido está em disputa. O militante da causa perdida das camadas supérfluas fará assim, nessa desconexão entre as palavras e as coisas, a experiência da famigerada arrogância dos atuais donos do mundo. Quem não ouviu essa voz diária da razão: vocês não estão entendendo nada quando falamos de "direitos", "reformas", etc., fomos mal compreendidos, o que é natural, dada a complexidade da nova ordem mundial, por isso vamos, didaticamente, explicar tudo de novo, até que vocês compreendam o que de qualquer forma lhes irá suceder, queiram ou não. Nessas condições, como orientar o pensamento e a vontade política na direção de uma "articulação democrática entre poder e direito", se no outro campo também se utiliza a argamassa dos "direitos da cidadania" para cimentar a aliança entre poder e dinheiro? Assim, ao avesso do economicamente correto parece corresponder o "direito" de um outro jargão, o da sociedade cidadã. Se "crise de paradigmas" ainda quer dizer alguma coisa - além de sacramentar a conversão da cultura oposicionista em cultura governista, mediante ajuste específico dos respectivos mapas cognitivos -, também deve ser isso. Um desempregado "estrutural" simplesmente se enganou de paradigma, tem mais é que se "comunicar" numa "multiatividade" qualquer: por que não tenta o charity-business? Nessa volta cínica do pêndulo, a outra cara da "crise de paradigmas", para a qual já está na hora de arrumar um outro nome.

Voltemos mais uma vez ao "espantoso deslizamento semântico" com o qual se debatem os ativistas do campo democrático-popular. Não se pode dizer que não estejam pelo menos em boa companhia. Também na visão dos afogados a semântica é uma das vítimas dos novos tempos: "quando chamam uma volta das relações de capital e trabalho do século 19 de 'modernidade', você sabe que está numa crise de significado ou numa roda de cínicos. Quando celebram a aprovação de uma lei que promove o abastardamento do serviço público e chamam isso de avanço, você descobre que a crise é terminal. Qualquer coisa quer dizer qualquer coisa, 'significado' perdeu o significado". ${ }^{17}$ Sendo o capitalismo uma máquina de produzir insignificância - não há conteúdo "significativo" que resista por muito tempo à indiferenciação da troca mercadorizada -, cedo ou tarde acabaria se dando essa implosão semântica final. Sem a bússola das palavras "significativas" que lhe permitam balizar o caminho da emancipação, compreende-se que a esquerda ten ha perdido o rumo - ou coisa pior: quando imagina ter recuperado suas referências normativas, estas são engolidas ato contínuo pelo redemoinho dos simulacros oficiais.

Nesse mundo das coisas trocadas e com significados intercambiáveis a ponto de não dizerem mais nada salvo o seu contrário, resvalando por isso mesmo até o grau zero do sentido, seria muito mais o caso de verificar se os papéis clássicos de esquerda e direita não se encontram igualmente invertidos. E é o que de fato parece estar ocor-

17. Luís Fernando Veríssimo, A versão dos afogados, Porto Alegre, LPM, 1997, p.340. 
rendo. Numa era que transformou o conceito de reforma social no seu oposto antissocial, já não espanta mais que progressistas e conservadores troquem de posição no tabuleiro ideológico. Os novos donos do mundo agora posam de vanguarda de uma necessidade histórica inexorável, diante da qual só as classes obsoletas, na sua inércia e despreparo para uma segunda modernidade, ainda se mostram recalcitrantes. Quando não entregam simplesmente os pontos clamando por mais exploração: agora com total liberdade de movimento, essa máquina futurista de triturar pode inclusive se dar ao luxo de ser apresentada como a única fonte de riqueza pela própria esquerda, que dela exige apenas a contrapartida do pranteado pleno emprego do ciclo anterior, enfim, mais alienação em nome de um ultrapassado direito ao trabalho assalariado. Então é isso o que se vê na vitrine da globalização: a esquerda na retaguarda, procurando conservar o que ainda sobra do Welfare State, acossada por um establishment que alega estar na crista da nova onda das forças produtivas. Conforme o caso, um passado de esquerda pode até ajudar no serviço de dominação, desde que preservado na forma do estereótipo evolucionista - pois estamos falando de um decalque vulgar, embora objetivo -, em suma um pequeno repertório de cacoetes retóricos acerca da força das coisas, processos anônimos ou coisas do gênero. Qualquer brasileiro sabe do que se trata: enquanto vai moendo no aspro, precisa aturar esse discurso aberrante que se poderia chamar de marxismo de classe dominante. Como se esse progressismo economicista em nome dos interesses estabelecidos não bastasse, a atual reviravolta os papéis costumeiros propiciada pela revanche do capital ainda oferece como suplemento espiritual algo como um existencialismo de mercado, tanto para edificação dos de bai- xo como para exaltação das proezas dos ganhadores. Para estes últimos, o aforismo de corte nietzscheano: "viver na globalização é viver perigosamente. Mas é viver, em lugar de estar sempre perdendo e se lamentando", nas palavras recentes de um medalhão da Era da Informação. Para os debaixo, que se compenetrem de uma vez que estamos vivendo numa Sociedade de Risco. Tanto é assim que nunca o capital se esmerou tanto na busca do risco zero mediante a socialização máxima dos prejuízos, como é do feitio de quem ama viver perigosamente. Quem, no entanto, está mal-acostumado a receber algum benefício da Previdência Social não deve imaginar que se trata de um direito natural: foram-se as estruturas de segurança em que estavam baseadas nossas velhas sociedades da Era Industrial, etc., etc. Proteção, além de obsoleto é um conceito filistino. Uma sociedade de risco, pelo contrário, exige de seus membros a autenticidade de tomar decisões cotidianas que envolvem é claro um "desafiador" risco pessoal: por exemplo, haverá um momento em que o vendedor de força de trabalho - caso encontre um comprador com a mesma fome existencial - terá que se decidir entre um preconceito do passado, como a ideia de direitos trabalhistas, e a nova realidade da precarização, como afinal o nome indica, um reencontro com a própria finitude. E por aí vamos. Puxando por esse fio, chegaríamos sem dúvida ao realejo meloso do jargão ético-gerencial que pudemos ver refletido no espelho das ONGs, em cuja retranca cidadã, convenhamos, nem sempre é fácil vislumbrar a plataforma de uma contra-hegemonia.

Quando qualquer coisa quer dizer qualquer coisa, o quadro parece mesmo terminal. Pensando bem, a sociedade da mercadoria total na qual passamos a viver não deixa de ser uma utopia conclusiva, possivelmente a úl- 
tima ainda em vida. Só que uma utopia negativa, própria justamente de um mundo às avessas. Assim, pela primeira vez na história nos defrontamos com uma visão utópica que não vem de baixo, gerada pelo inconformismo difuso dos movimentos antissistema que acompanham o capitalismo desde o berço. Mas irrompe do alto: no lugar do extinto sentimento libertário do mundo, a utopia destrutiva de uma exploração sem limites. ${ }^{18}$ Daí esta outra espantosa inversão, matriz social de todas as demais: desde que entraram em cena ao apagar das luzes da era liberal, tirando o sono das elites, as massas pela primeira vez deixaram de constituir uma ameaça à ordem estabelecida e aos valores do Ocidente, chegando agora até a funcionar como os verdadeiros pilares da sociedade; pelo contrário, a principal ameaça vem hoje daqueles que se encontram no topo da hierarquia social. ${ }^{19} \mathrm{O}$ caráter predador das novas classes rentistas mundiais que o diga.

Um retrospecto histórico talvez ajude a esclarecer um pouco o girar em falso desse mimetismo semântico em que direita e esquerda no Ocidente, espelhando-se uma na outra, acirram seu desentendimento de fundo, que por vezes ninguém sabe qual seja pois o dissenso parece se declarar na mesma língua do consenso.

Quando o ativista de uma ONG anti-establishment se envolve numa disputa política em torno do sentido das

18. Na definição de Pierre Bourdieu, "L'essence du néoliberalisme”, Le Monde Diplomatique, março de 1998.

19. Christopher Lasch, A rebelião da elites, Rio de Janeiro, Ediouro, 1995, p.37. palavras "direitos", "cidadania", "espaço público", “equidade social" etc., é porque se ressente da pouca ou quase nenhuma nitidez - para não falar em promiscuidade - na demarcação dos campos em conflito. Uma nitidez clássica por assim dizer, dos tempos em que o bate boca entre as classes sociais (na boa fórmula de um clássico) se dava numa chave de compreensão imediata quanto aos termos irreconciliáveis do litígio. Não ocorreria a nenhuma das classes antagônicas representar o papel histórico da outra - topar por exemplo com a imagem farsesca de um "direitista" furiosamente mudancista, ou mais exatamente, paladino da mudança pela mudança, como hoje é de bom tom no capitalismo turbinado. Simplesmente porque ao longo do capitalismo moderno a ideia de transformação social positiva e politicamente induzida fazia sentido, e sentido comum, como um código de interpretação do novo curso do mundo, lido ora à maneira retroversa dos conservadores, ora à maneira subversiva dos socialistas, ora à maneira oligárquico-progressista pelas classes proprietárias liberais. Um quadro de referências no interior do qual se pensava e confrontava a normalidade burguesa que emergira na primeira metade do século passado, em função das quais tal normalidade ela mesma passava pelo crivo da rejeição, da reforma ou da superação. Descartando a reação tradicionalista, concentremo-nos no antagonismo entre liberais e socialistas, embate ao qual se deve o vocabulário comum, porém antitético das lutas sociais durante quase dois séculos de modernização capitalista. Se acrescentarmos que a terra de ninguém ideológica entre as duas trincheiras era ocupada pela ideia fixa do Progresso, linearmente advogado pelos liberais e contraditoriamente, pelos socialistas, seremos levados a reconhecer que os movimentos burgueses de emancipação, 
emancipação, bem entendido, dos vínculos estamentais-corporativos herdados do Antigo regime - uma emancipação negativa, portanto - forneceram a "geocultura de legitimação do capitalismo histórico", mas também que a contestação das classes perigosas, desde o momento em que renunciaram a um projeto próprio de contrassociedade à margem do processo de proletarização das populações expropriadas, se deu na forma de uma crítica, porém em nome de virtualidades universalistas não cumpridas que, se tomadas ao pé da letra, entretanto, ameaçariam a própria acumulação privada, mas não o passo adiante rumo a uma forma superior de sociedade. Neste sentido, o socialismo podia e devia se apresentar como a verdade e realização superadora do próprio liberalismo. Nada mais ambivalente, entretanto, do que este contraponto entre inclusão crescente, por assim dizer forçando a porta da boa sociedade a cada rodada de expansão e institucionalização de direitos, e o propósito libertário do grande salto antissistema, o qual só provaria ser verdadeiro caso conseguisse demonstrar na prática ser igualmente portador de uma tarefa histórica da humanidade para a realização da qual o antagonista até então mais "avançado" já daria sinais de obsolescência. Em suma, campo e contracampo armados para o confronto final, porém com a determinação singular de que o coveiro encarnasse o futuro "paradigma" dominante, a ponto de falar a mesma língua da inovação histórica em ruptura com as continuidades tidas até então como naturais.

Antes de prosseguir, algumas referências. "Geocultura de legitimação do capitalismo histórico" é uma fórmula de Immanuel Wallerstein, por extenso mais ou menos a seguinte: em fins do século XVIII, boa parte do planeta já fora englobada pela economia capitalista, cujas principais instituições também já estavam então bem consolidadas, a saber: "uma divisão axial do trabalho, com significativa transferência de valor excedente das zonas periféricas para as centrais; primazia da recompensa para os que atendiam aos interesses da cumulação interminável de capital; o sistema interestados composto pelos chamados Estados Soberanos, que, no entanto, eram restringidos pelas estruturas e pelas regras deste sistema; e a sempre crescente polarização deste sistema-mundo, não apenas econômica mas social e a ponto de se tornar também demográfica". ${ }^{20}$ Um século de Iluminismo, socialmente institucionalizado a partir da Revolução Francesa, acabou decantando a "geocultura de legitimação" de que ainda carecia a economia capitalista mundial enquanto sistema histórico, centrada em dois focos em torno dos quais passou a girar a vontade dirigente dos dominantes e o consentimento das populações enquadradas pelas instituições enumeradas acima: a normalidade da mudança política, até então coisa excepcional, e a soberania do "povo", não mais prerrogativa do "soberano". Está claro que um fundo comum de certezas explorado em direções antagônicas. Se a mudança política era normal e o povo seu agente, tudo seria possível, até mesmo uma ameaça igualitária às hierarquias básicas sem as quais não se reproduz um sistema que não acumula se não polarizar classes sociais, poder político dos estados e a riqueza das nações. Daí o problema: como impedir as classes perigosas de levar muito a sério tais normas? Pelo menos durante dois ciclos de acumulação sistêmica - respectivamente, a Pax Brittanica e a Pax Americana - a estratégia ativa do "reformis-

20. "As agonias do liberalismo", in Emir Sader (org.), o mundo depois da queda, Paz e Terra, SP, 1995, p.33. 
mo racional", encarnada pela via média liberal, resolveu satisfatoriamente o dilema, acomodando o medo conservador e a impaciência dos radicais. Supremacia posta a prova pela primeira vez na virada do século XIX para o $\mathrm{XX}$, quando os povos do mundo inteiro, e não apenas as classes trabalhadoras europeias, também passaram a exigir "mudança política normal" e "soberania”. Ocasião para os liberais reafirmarem sua hegemonia ameaçada, estendendo o reformismo racional - ou melhor a promessa encerrada na definição do seu conceito progressista a todo o sistema mundial, reativando noutro registro o mito de origem, enunciado pela primeira vez por Adam Smith polemizando com os mercantilistas acerca da progressiva homogeneização do espaço econômico mundial, a despeito da evidência histórica de sua sempre reposta estratificação. Vistas as coisas por este ângulo histórico-mundial, a expressão "geocultura de legitimação" parece mais adequada a este cenário do que a noção clássica, porém mais doméstica de "ideologia", embora exercendo as mesma funções de encobrimento e racionalização, no caso, a desigualdade recorrente na distribuição de riqueza e poder no interior da economia-mundo capitalista. Trata-se, portanto, de uma cultura comum (de âmbito geopolítico, por assim dizer), alimentada pela mesma crença no projeto moderno de equiparação entre os povos segundo os mesmos parâmetros de homogeneidade social e convergência no bem-estar econômico, ainda que as vias para se alcançar tal estágio final fossem simetricamente antagônicas, como ficou claro a partir de outubro de 1917. Mesmo assim, não custa voltar a relembrar - como aliás justamente dá a entender a expressão "geocultura de legitimação do capitalismo histórico" - que até mesmo (ou sobretudo?) o marxismo, do Manifesto até as teorias mais heterodoxas do Imperialismo, raramente deixou de compartilhar o credo geocultural da convergência propiciada pela propagação do capitalismo, de qualquer modo a encarnação contraditória do mesmo "progresso" de que falavam os liberais, cuja supremacia estratégica fica então mais fácil de entender. ${ }^{21}$

Há mais, como mencionado linhas acima no capítulo das promessas universalistas de inclusão, sem as quais a geocultura do capitalismo histórica perderia sua aura legitimadora. Na conhecida parábola liberal-progressista de T.H. Marshall, o processo de modernização capitalista também se apresenta como uma sucessão ascendente de direitos - civis, políticos e finalmente econômico-sociais - mediante os quais se assegura e amplia a condição de “cidadão". Esta mesma parábola da "inclusão" - via universalização de demandas conflitivas e assimilação de novos atores, percorrida à esquerda e à direita como uma mesma trilha progressista de integração e portanto de justificação tácita do sistema que se abre para acolher os recém-chegados - também poderia ser recontada nos termos, expostos acima da geocultura do sistema mundial, centrada na visão mobilizadora da superação da defasagem entre as localidades da acumulação a cada rodada dos ciclos sistêmicos. Assim, a hegemonia britânica expandiu o sistema através da inclusão das nações de colonos, mais exatamente mediante a elevação dos direitos de propriedade dos antigos colonos acima dos direitos de soberania

21. Ver a respeito, do mesmo Wallerstein After Liberalism, cap.6 ("The concept of national developement, 1917-1989: elegy and requiem") e cap.9 (“The geoculture of developement"), New York, The New Press, 1995. Para uma retomada brasileira deste raciocínio, à luz do desmanche nacional em curso nesta última década, ver a Introdução de José Luís Fiori ao vol. coletivo Estados e Moedas no desenvolvimento das Nações, Petrópolis, Vozes, 1999. 
dos governantes metropolitanos, "democratizando" o direito ao "nacionalismo". A ruptura antissistema de 1917 almejava subverter, e revelava ao mundo o escândalo, a dupla exclusão na qual se baseava a Pax Brittanica, a dos povos não ocidentais e a das massas não proprietárias ocidentais. Em resposta à ameaça representada pela Revolução Russa, cujo anti-imperialismo defendia o direito dos povos à autodeterminação, prescrita aliás pelo ideário iluminista original, como se viu, e cujo internacionalismo proletário defendia a primazia dos direitos de subsistência sobre os direitos de propriedade e de governo, o hegemon do ciclo subsequente, o da Pax Americana, não teve remédio senão elevar o bem-estar de todos os cidadãos - o imperialismo do consumo de massa - acima dos direitos absolutos de propriedade, sem falar na "proletarização" do nacionalismo, via descolonização e industrialização consentida na periferia. ${ }^{22}$

Por fim, na Teoria da ação comunicativa (1981), Habermas oferece um quadro evolutivo dos ciclos de "juridificação" daquelas mesmas relações sociais de inclusão - objeto da classificação jurídica em sequência mencionada no parágrafo anterior. $O$ interesse de tal esquema reside no entrelaçamento da progressiva ampliação dos direitos de acesso e participação dos indivíduos em um número cada vez maior de subsistemas - dos mercados e parlamentos à seguridade social - com as metamorfoses, também em sequência histórica, do Estado-Nação - do Estado absolutista burguês dos tempos do individualismo possessivo teorizado por Hobbes, ao Estado Social do consenso keynesiano do pós-guerra. Quis no entanto a irônica

22. Ver Giovanni Arrighi, O longo século XX, cap.1 ("As três hegemonias do capitalismo histórico”), Rio de Janeiro, Contraponto, 1996. defasagem entre o otimismo da Teoria da Ação Comunicativa e a marcha recalcitrante do seu objeto rumo à almejada tensão virtuosa entre democracia e capitalismo, que uma tal exposição sistemática daqueles ciclos progressistas se completasse justamente no momento em que principiava uma dramática reversão dessas ondas longas de assimilação social pelo reconhecimento de direitos, sob a pressão da acumulação que se mundializava - bifurcação "patológica" não prevista pela Teoria, que precipitadamente, muito impressionada pela regulação do Welfare State e os trinta anos de crescimento que sustentaram tal programa de pacificação social, normalizara e congelara o capitalismo na forma dos meios autonomizados de integração sistêmica "poder administrativo" e "economia monetária”. ${ }^{23}$

Embora seja coisa sabida, recordemos os passos seguintes de nosso roteiro. Depois de duas guerras mundiais e duas revoluções vitoriosas na periferia, selando a implosão do século liberal, tudo indicava, à vista da intensificação da luta social e da correspondente escalada ideológica ${ }^{\mathbf{2 4}}$, que

23. Creio que não por acaso a exposição de Fernando Haddad trata precisamente desse processo de desjuridificação, mais exatamente da economia política desta reviravolta espantosa, a ponto do autor se perguntar se de fato não se tornou impossível, em bases capitalistas, manter uma tal ampliação histórica de direitos.

24. "Ideologia" aqui na acepção em que o termo acabou sendo tomado na esteira dos movimentos de massa que, desde meados do século passado, à imagem e semelhança dos movimentos burgueses de emancipação dos tempos da Revolução Francesa, se autodefiniam por meio de interpretações globais da história e que assim se endereçavam à consciência política dos correligionários e companheiros de luta - socialistas, anarco-sindicalistas, comunistas, etc. Ideologias de segunda geração, na boa observação de Habermas, para distingui-las da matriz da qual Marx extraíra a noção materialista de Ideologia, a 
o fim do capitalismo não era de fato implausível - no conhecido diagnóstico de Schumpeter, por exemplo. E, no entanto, mediante uma dosagem bem calibrada de reformas no centro e revoluções nacionais na franja do sistema, três décadas de acumulação mundial tornaram realidade o paradoxo de um século americano, ao longo do qual se fortaleceu numa escala nunca vista a plataforma social do campo oposto. Deu-se então a virada geocultural que está nos interessando. A bem dizer à beira do túmulo, a pedra fundamental do liberal-progressismo, na figura catalisadora do desenvolvimento mundial-convergente, ganhou uma nova e miraculosa sobrevida. Sucederam-se os milagres econômicos conhecidos, reforçando a autoridade incontrastável - à direita e à esquerda - daquela geocultura originária, relançando mais um ciclo histórico do interminável bate-boca entre o Partido da Ordem e do Progresso e os socialistas em campanha pela emancipação social que afinal adviria do desenlace daquele mesmo Progresso de abrangência máxima, tanto mais verossímil quanto em meados da década de 70 o fosso entre núcleo orgânico e periferia do sistema mundial parecia de fato estar finalmente se estreitando. Também sabemos, no entanto, e não custa repetir, como foi curto o verão de mais essa ilusão. De sorte que mal começada a década seguinte, os supostos milagres recuperadores do "atraso" se esfumariam um a um como um cortejo de miragens. Primeiro a desintegração do continente africano e seus modestos e raros casos de sucesso econômico; mais adiante, o colapso da modernização nas periferias industrializadas, notada-

cultura burguesa da Idade Clássica, tal como tomara forma no Direito Natural Moderno, na Economia Política, na Epistemologia, na Literatura etc., em seu duplo caráter utópico e ideológico. Cf. Jürgen Habermas, Teoria da ação comunicativa, trad. espanhola, Madri, Taurus, vol.2, pp.499-500. mente latino-americanas, culminando com o naufrágio do antissistema soviético. Todavia, a ruína espetacular do socialismo real encobriu duas décadas de desastroso declínio da economia mundial no seu conjunto, incluindo-se neste plano inclinado o malogro das tentativas, ora encabuladamente keynesianas, ora monetaristas, de recuperação europeia. Além do mais, como até a derrapagem fatal de 97 a máquina asiática de crescimento parecia manter-se em funcionamento, sob a fraseologia da globalização e seu elenco de desregulamentações milagrosas, o mito geocultural da mobilidade ascendente na hierarquia de riquezas das nações ainda animaria uma última década de apoteose mental das elites econômicas e políticas mundiais. Pelo menos desde que a moratória russa se seguiu à queda dos tigres asiáticos, até mesmo os mais triunfalistas reconhecem que tão cedo o capitalismo global não recobrará sua aura de infalibilidade no cumprimento da profecia progressista da convergência. ${ }^{25}$

Daí o vácuo ideológico em que foi precipitada a luta das classes e das nações pela riqueza capitalista, devolvendo-nos ao "espantoso deslizamento semântico" que arrastou consigo os derradeiros fragmentos do discurso antissistema. Assim, de norma geocultural, o liberalismo histórico foi relegado à condição de mero competidor no mercado de ideias. ${ }^{26}$ Sem dúvida, vencedor até o último

25. Acerca desse desencanto de elite com a derradeira metamorfose da utopia liberal - a revelação, indolor para os de cima, de que a simples competição intercapitalista em mercados desregulados e globalizados não assegura o desenvolvimento e muito menos a convergência entre as economias nacionais do centro e da periferia - ver José Luís Fiori, loc.cit. Ver ainda, na mesma direção, Serge Halimi, "Le naufrage des dogmes libéraux", Le Monde Diplomatique, out.1998. Para um ponto de vista oficial e mais à mão, cf. p.ex. Joseph Stiglitz, economista sênior do Banco Mundial, "O pós-consenso de Washington", FSP, 12.07.98.

26. Na opinião otimista de Wallerstein, supondo-se que ainda existam “ideias” 
crash global, e mesmo depois do próximo, pouco importa, nada lhe devolverá mais o status anterior de "ideologia" (de primeira ou de segunda geração, no sentido indicado), quer dizer, de falsa consciência, movida, no entanto, pelo grão de verdade germinando em palavras enfáticas como Justiça, Humanidade, Progresso etc. Desse grau zero o melhor atestado se encontra na retomada imperial da hegemonia americana desde meados dos anos 80, à qual obviamente não se pode tomar na sua acepção clássica de liderança intelectual e moral, sobretudo à luz do engessamento imposto aos concorrentes da Tríade, sem falar no desmanche das periferias (noves fora suas elites assimiladas pelos serviços subalternos da dominação). Por mais imperial que seja tal poder, trata-se de fato de uma fuga para a frente ancorada exclusivamente na emissão do dinheiro mundial, cujo único lastro já não é mais do que o poder das armas, e desde a Guerra do Golfo até à atual Guerra Sérvia, um poder nu e cru, sans phrase, desprovido de maiores convicções salvo a histeria humanitária, exercido de resto sobre um planeta em guerra civil endêmica, na verdade a forma burguesa normal da concorrência econômica entre os perdedores globais, aos quais de resto as bombas não cessam de dar um só recado: cem mil kosovares, ou qualquer outra população sem valor de troca, não valem a vida de um só fuzileiro americano.

Porém tampouco o socialismo, mesmo livre finalmente do campo de atração magnético da geocultura originária do capitalismo histórico ${ }^{27}$, conheceu uma segunda

na esfera da circulação. Na apologética corrente, costuma-se camuflar o fenômeno sob a fórmula positiva "fim das ideologias", sem as quais deverão viver doravante as sociedades complexas pós-utópicas.

27. Outra fórmula do mesmo Wallerstein. juventude, por certo na falta de um processo larvar de autossuperação do sistema mundial visível na linha do horizonte. Mas nem por ocorrer numa terra de ninguém ideológica, os Estados nacionais ou seus sucedâneos regionais, deixarão de competir com outros Estados para serem o centro da acumulação de capital, como tampouco as camadas não-proprietárias, presume-se, suportarão passivamente que os fundos públicos arquem com a corrida das empresas ao corte de custos: de qualquer modo a guerra social promete assumir proporções inéditas, sem no entanto oferecer garantias que trará consigo a chave superadora de uma eventual recaída na barbárie. A guerra das palavras não poderia ser uma exceção. O derretimento semântico que a caracteriza (tal como o melting down das moedas) demonstra finalmente que na cena geocultural não há mais um discurso dominante comum. ${ }^{28}$ E por isso mesmo (vale a insistência) parecem dizer a mesma coisa numa pastosa língua geral, algo como um inócuo dever-ser, exortação normativa que vai sancionando o sombrio esfarinhamento da legitimidade progressista da civilização capitalista. Que afinal se apresenta tal qual é e no fundo sempre foi: um absurdo processo de acumulação de capital para se acumular mais capital. Dessa falta básica de sentido deriva uma outra guerra: uma infindável batalha, dita cultural de uns tempos para cá, cujo girar em falso, não obstante se apresenta como o programa substitutivo da finada Grande Política, na realidade um fim de linha. Há pelo menos uma década tem sido este o recado das bombas. 


\section{Sofística da assimilação*}

A cultura nunca esteve tão festivamente na moda como nos dias de hojel. Uma conjuntura altista tanto mais surpreendente quando se sabe que o encilhamento da vida mental pela maré fundamentalista do economicamente correto nunca foi tão incontrastável como nestes mesmos tempos de apoteose do dinheiro. Ou será por isso mesmo? Em todo o caso está aí o auge brasileiro recente que não deixa mentir. Só no eixo Rio-São Paulo, megaexposições levaram nos últimos quatro anos quase dois milhões de visitantes aos museus para ver de perto Rodin, Miró, Goya, Monet, Camille Claudel, Dali, Botero, Basquiat, Picasso (Suite Vollard), Anselm Kiefer etc. É bem verdade - só para reintroduzir de outro ângulo a sugestão

* Publicado na revista praga n.8, SP, 1999.

1. Uma constatação corriqueira no início de novembro de 1998 - na abertura de uma conferência de Otília Arantes sobre o lugar da cultura nas novas "estratégias" urbanas, apresentada no Simpósio Internacional sobre Espaços públicos e Exclusão sociocultural, promovido pela FAU-USP - deixa de sê-lo quando reprisada um mês depois, graças ao acaso objetivo que levou o jornalista (no bom sentido) Cláudio Cordovil a abrir sua matéria acerca da recente onda brasileira de exposições de artes plásticas em escala industrial, observando também que a arte contemporânea está mesmo na moda. Fechando o círculo, seria o caso de assinalar desde já que o artigo em questão saiu no mesmo número da revista Veredas de dezembro de 1998, no qual se publicava uma versão resumida da referida conferência - "Vendo Cidades" -, mais uma vez não por acaso, órgão de um Centro Cultural, e de um Banco, por enquanto ainda público, o Banco do Brasil. O que segue são as páginas introdutórias de um estudo mais amplo acerca dos tópicos iniciais daquela conferência, mais exatamente, o jogo entre o interesse econômico da cultura e as alegações culturais da economia. Com sorte, integrará um livro planejado a quatro mãos sobre a ressaca cultural, a desgraça econômica e o urbanismo de última geração, no qual se exprime algo como um "pensamento único" das cidades. 
de há pouco - que a recém finada fase do Real forte "vai passar para a história como o reino da fantasia" ${ }^{2}$. Dando notícia deste castelo de areia - à vista do atual estado das artes, tudo indica que o segundo mandato não passará de uma visão, como no painel alegórico em que Aurélio de Figueiredo anteviu a coroação da princesa Isabel entre "nuvens crepusculares" - sirva ainda de amostra o engarrafamento paulistano de outubro do ano passado, o mês mais cultural do ano segundo alardeava a mídia, depois de uma semana de hemorragia nas reservas internacionais, por motivo da remota e injusta crise russa, conforme apregoava a mesma mídia: uma Bienal de Artes Plásticas,

2. Como dizia, em palestra no Centro de Estudos Brasileiros em Paris, Celso Furtado, estando o dólar cotado pela média do Banco Central a 1,77, acumulando uma alta de $48,64 \%$ desde a alteração da política cambial. O Estado de São Paulo, 4 de fevereiro de 1999. Trata-se de uma fantasia recorrente como é fácil reconhecer pelo seu inconfundível ar de família. Quem não viu este filme antes? Inclusive pela alternância de sempre entre a excitação pela novidade da etapa do momento que nos distanciaria das humilhações coloniais costumeiras, e o desconsolo resignado de vê-las ressuscitar na primeira curva do caminho. Novamente é o que parece estar ocorrendo com o atual surto do bovarismo nacional. Assim, menos de um ano antes de mais uma fantasia desfeita, o crítico cultural Marcelo Coelho - como ele mesmo se autodenomina num artigo que trata dos dilemas recentes da profissão - acreditava que a exposição Rodin fora de fato um marco: "as filas formadas na Pinacoteca estavam demonstrando que a cidade de São Paulo já entrara numa nova fase de consumo cultural (...) Depois de Rodin tivemos Monet e Camille Claudel; no campo da música erudita, grandes nomes como Kissin, Pogorelich, e orquestra do Gewandhaus" (FSP, 11.03.98). Essa a boa notícia acerca dos melhoramentos da vida moderna, que em boa consciência não podemos dispensar. Nela, entretanto, transparece ao primeiro relance a condição colonial de sempre à espreita, como estamos agora refazendo a experiência: "vantagens da globalização e da moeda 'forte': importamos carros japoneses e voltamos aos bons tempos do café, quando as grandes estrelas da ópera - Caruso, Gigli etc. - passavam pelo Rio, por São Paulo e Buenos Aires". Está claro que nem por isso deixa de existir o problema, de cuja tentativa de identificação estamos partindo: a transformação da cultura de elite em atração de massas, cujo capítulo brasileiro confirma pelo menos o vínculo indispensável com o processo global de financeirização da riqueza, capítulo anunciado pelo "aparecimento de uma camada de consumidores culturais mais sofisticados", ainda nas palavras do articulista, e nas bancas, pelas "revistas culturais, coloridas, com boa distribuição e aparentemente viáveis do ponto de vista econômico". Outra boa notícia. uma Mostra Internacional de Cinema, um Festival disso e outro daquilo, aos quais seria preciso acrescentar a safra habitual, porém cada vez mais sobrecarregada - e estafante para os aficcionados -, de espetáculos, exposições, ciclos de conferências etc. Assim como fomos os últimos a entrar no mundo de faz-de-conta da moeda forte, também chegamos tarde nessa corrida do ouro cultural, deve haver portanto muita demanda reprimida nesses escores que não ficam nada a dever ao similar europeu ou americano - as blockbuster exibitions, como as chamam seus inventores, ainda comemorando os seus 400.000 visitantes para a retrospectiva de Cézanne da Tate Gallery em 1996, ou mais recentemente as quase 600.000 pessoas em Boston para a mostra "Monet no século 20", agora estourando bilheterias na Royal Academy of Arts, em Londres. Seja como for, o fato é que nos últimos anos também num país periférico recém "ajustado" e agora em vias de "aprofundar a agenda" - essa expansão nunca vista da oferta chama a atenção, sobretudo pela escala e composição social da resposta, sancionando por sua vez as políticas de “ação cultural" de governantes e empresas, associados ou não nas famigeradas "parcerias", responsáveis, tais políticas, pela multiplicação de Centros Culturais, Espaços Culturais e o que mais se habilitar a receber a chancela "cultural" mediante cadastro no órgão competente e tutela da respectiva lei de incentivo.

Ocorre que a cultura não está na moda de uma maneira trivial. Não se poderia falar de modismo, ou coisa que o valha em termos de inconstância ou veleidade, a propósito de um sintoma que já dura duas décadas, pelo menos nos países centrais. É que a moda propriamente dita não é mais a mesma desde que o estilo tornou-se objeto de consumo de massa, não importa a matéria estilizada, se 
vestuário, ética ou decoração de interiores. De sorte que mesmo nas manifestações mais estereotipadas do antigo regime da moda, transparece algo dessa nova condição. É o caso dos hábitos culturais dos círculos de elite, que nos interessaria caracterizar agora, depois que a chamada alta cultura dos museus, e todas as suas variantes, também ingressou, não sem tempo, na vala comum da sociedade do espetáculo. Assim, não foram apenas os cadernos de variedade que abriram espaços generosos para as notícias e comentários culturais. Também o colunismo social passou a ditar moda na faixa cultural, é bem verdade que num domínio que nunca deixou de ser apanágio do autodenominado high life, mas com uma sintomática inflexão pop, claro que na acepção chique do termo. Basta reparar, por exemplo, no maneirismo vocabular com que os colunistas realçam a coreografia de vernissage ou saguão de noitada lírica: neste novo baile de máscaras, socialites também atendem agora pelo nome de "arteiros" e "culturetes", quando não estritamente "modetes" ou vice-versa, quanto mais "arteiro" maior o toque de classe nessa apresentação do mundo a si mesmo que é uma coluna social à altura do seu tempo. Exagero? Pois não é que o novo colunismo chegou até mesmo a pautar considerações filosóficas sobre a "arteirice" da arte conceitual? Mas por outro lado, algo das imensas filas à porta da Pinacoteca do Estado deve ecoar nesse barateamento categorial, inesperado ponto de encontro entre o topo e os andares inferiores do edifício social, de certo modo confirmando o advento de uma sociedade reestruturada de ponta a ponta pela lógica da moda. ${ }^{3}$

3. Como quer, por exemplo, Gilles Lipovetsky, O Império do Efêmero, São Paulo: Cia. Das Letras, 1989.
Antes de prosseguir, duas palavras de estímulo à objeção corrente nos dias de hoje. Pois quem rebaixa assim essa recém alcançada "reconciliação das massas com as musas" - nas palavras de um teórico dos pós-modernismo -, comparando-a inclusive ao arrivismo esforçado dos "culturetes", não importa se de alto ou de baixo escalão, estaria simplesmente estendendo à atual reviravolta na recepção de massa da cultura superior, a mesma e inepta condenação de sempre da indústria cultural com que a antiga Teoria Crítica afinal confirmou sua inatualidade de nascença. No fundo, não é de outra coisa que se trata, com o sinal trocado, é claro, mais exatamente, de uma verdadeira metamorfose da indústria cultural, que também ingressou, como não podia deixar de ser, num regime de acumulação flexível e economias de escopo, em contraste com a rígida homogeneidade fordista (mas será mesmo que este derradeiro avatar evaporou?) - a única dimensão (segundo se diz) que a velha guarda frankfurtiana chegou a conhecer e a partir da qual formulou o seu diagnóstico sobre o achatamento ideológico do capitalismo avançado. Assim sendo, não faltará entre os defensores das novas práticas de curadoria quem contraponha à tamanha e preconceituosa má vontade com a popularidade dos museus e das exposições arrasa-quarteirão, o fato de que tal fascinação pela alta cultura corresponde a um desejo realmente existente, que sem dúvida percorre todas as classes e é com certeza sintoma de uma bem vinda mutação, e tudo isso "não importa o quanto a indústria cultural estimule, seduza, manipule, atraia e explore". ${ }^{4}$ Não diremos que não, longe disso. Embora o amor à arte seja sempre suspei-

4. Andreas Huyssen, Memórias do Modernismo, Rio de Janeiro: Ed. da UFRJ, 1997, p. 237. 
to, em qualquer circunstância e classe social. Outra consequência de um velho teorema frankfurtiano, diga-se de passagem, segundo o qual a obra de arte se aproxima do conhecimento, e teme mais que tudo a isca da fruição estética, justamente pelo seu "ódio à Arte". Como o do violinista murmurando entre dentes, sob a regência de um Toscanini arrebatado: "I just hate music". Muito menos que não se trate de uma ruptura de época considerável, como a do próprio capitalismo desde que principiou o seu longo downturn ao fim das três décadas ditas gloriosas do consenso keynesiano de pós-guerra. Aliás não estamos falando de outra coisa. Mesmo assim, seria preciso qualificar melhor esse desejo, que de resto também se exprime (por que não?) na celebração teórica (por assim dizer) dessa corrida de massa à cultura conservada nos museus.

Assim, tão revelador quanto as elocubrações de um culturete anônimo numa sala de espera acerca do Conceito - a "ideia" por trás da obra, a "regra" de um jogo de linguagem -, pode ser o brado retumbante de um diretor executivo de museu, de preferência na versão original: "Art is sexy! Art is money-sexy-social-climbing-fantastic!"5 É isso aí. Há um século atrás mais ou menos - numa época aliás em que uma verdadeira couraça ideológica só deixaria filtrar essa confissão, de outro modo impossível, num registro da mais alta e nuançada hipocrisia -, o olhar justiceiro de um Veblen certamente reconheceria nessa singela enormidade mais uma confirmação de que não há nada que esteja na moda que não envolva, entrelaçadas, rivalidade sexual e luta de classes, mas sobretudo a contra-

5. Pensamento delicado atribuído a um antigo diretor do Metropolitan Museum of Art de Nova York, citado por Chin-Tao-Wu, "Embracing the Enterprise Culture: art institution since the 1980", New Left Review, n.230, 1998, p. 33. prova de que a cultura, como pudera verificar estudando justamente os precursores das atuais classes ociosas, aliás ele próprio contemporâneo da invenção do mecenato moderno pela plutocracia americana, "nunca foi outra coisa além de propaganda e exibição de poder, roubo e lucro". ${ }^{6}$ Meio século atrás, no estágio fordista inaugural da indústria cultural, tal grito premonitório de triunfo simplesmente traduziria a regressão da sublimação, propiciada pela grande arte aurática, às formas primitivas de desrecalque investido no logro do alpinismo social prometido para poucos. Ouvida enfim aquela tirada assustadora (há sempre algo de ameaçador no consumo ostentatório dos dominantes), na sua hora histórica de agora, que é a do vínculo não trivial da moda cultural com a cultura dos negócios - nexo que nos interessará mais adiante deslindar, e que é assim tão acintosamente exibido por um "animador cultural”, no qual não por acaso se fundem numa só persona o diretor artístico e o executivo financeiro -, já não chocaria tanto, pelo contrário, soaria até plausível e familiar. Ao que parece sem conhecimento daquela baixaria de alto nível, já se disse que não deve ser atoa que a alta visibilidade de que goza o star system que dita a moda cultural de hoje - das galerias minimalistas aos museus mais espalhafatosos - sublinha ainda mais (e só pode ser com traço grosso) a qualidade necessariamente sexy que a cultura deve possuir para se tornar enfim mola indutora da acumulação. ${ }^{7}$

6. Só para sustentar a nota, no comentário de Adorno, cf. Prismas, São Paulo: Ática, 1998, p. 74.

7. A referência à "sexy quality of culture as a motor of economic growth" é de Sharon Zukin, The Cultures of cities, Blackwell, Cam. Mass., 1995, p. 13. Inútil dizer que voltaremos ao ponto, aliás crucial para o presente argumento, a saber, nas palavras da Autora que se acabou de citar, que a cultura além do 
Mas será mesmo que as megaexposições de Monet ou Rodin oferecem ao mundo de gente que se acotovela nas bilheterias algo que a cultura de massa manufaturada não poderia mais proporcionar, uma gratificação extra fora do alcance quase ilimitado da televisão e da indústria cinematográfica high tech? Na curiosa opinião do teórico supracitado $^{8}$, é isso mesmo que ocorre: segundo pensa - e até aí não se destaca dos seus colegas da esquerda cultural - bater sempre na mesma tecla elitista das grandes mostras que apenas cooptam, reprimem e esterilizam, leva à paralisia (e é preciso se mexer, fazer as coisas culturais acontecerem) que sequer permite reconhecer o que interessa, o quanto as novas práticas de curadoria e os novos espectadores fizeram do museu um espaço muito diferente da modernidade clássica etc. Até aqui, como se disse, o trivial variado em que convergem a jovem esquerda atualizada e o establishment da administração cultural new look. Nosso autor inova quando sugere que no atual estágio da sociedade de consumo, o nível de expectativa visual encontra-se de tal modo saturado por obra da grande mídia, notadamente a televisão, que acabou suscitando - conforme crê - algo como uma aspiração insatisfeita por "experiências e acontecimentos" numa intensidade tal que o "desejo pelas imagens" se transforma no desejo por alguma coisa outra. Sempre segundo o Autor, um surpreendente desejo de "autenticidade" - isso

mais é um meio poderoso no controle das cidades, como se pode depreender desde já da percepção triunfalista do apelo sexual do dinheiro magnificado pela irradiação do sistema ampliado das artes superiores. Veremos no seu devido lugar, se Ms. Zukin empregou a palavra "motor" em sentido figurado ou literal. Pelo sim pelo não, o jovem Marx diria que a Cultura está se tornando a "isca" predileta do Capital.

8. Andreas Huyssen, op.cit., p. 248. mesmo, autenticidade encarnada, no caso, na materialidade dos objetos em princípio localizados fora do circuito destrutivo das coisas destinadas ao lixo. Já ouvimos isso antes. Mais precisamente nos tempos de resistência "cultural" à contrarrevolução em marcha durante a década de 70. Seja como for, trata-se nada mais nada menos do que uma declaração de confiança nalguma coisa como um bom "reencantamento" do mundo - e isso por iniciativa do novo gosto popular pela cultura dos museus, uma tendência social que os grandes números comprovam. Acontece que esse palpite incongruente não viria ao caso se não assinalasse malgrado seu uma outra não menos reveladora coincidência, agora em linha com o argumento esboçado até aqui. Só para reforçar o parentesco enunciado a seguir, não custa recapitular a opinião corrente acerca do museum-boom dos anos 80: que os novos museus, concebidos como ambientes totalmente espetaculares, procuram atrair públicos mais amplos, antes inibidos pela tradição que os consagrou como espaços exclusivos do connaisseur, do observador sério e instruído no convívio costumeiro com os segredos iniciáticos da alta cultura, espaços que proporcionariam doravante - sendo eles mesmos "locais de espetáculos, sensações, ilusões, montagens" - "experiências", em vez da inculcação de sempre das hierarquias simbólicas do saber canônico dominante. Ora, nosso primeiro teórico - Andreas Huyssen -, sem ser menos apologético, inverteu o raciocínio: tudo se passa como se, enfarados com a pirotecnia visual, os novos e numerosos recrutas da cultura com maiúscula quisessem mesmo um suplemento que os eleve às altas paragens da grande Arte. (Veremos logo mais que não diz só isso, antes contrapõe, como era de se prever, à indústria de artefatos imagéticos uma demanda coletiva por diferenciação 
cultural, algo como uma experiência comparatista da diferença). No que não está só, até bem acompanhado - ele e as pequenas multidões cuja animação cultural advoga -, no caso, por um número crescente, digamos de "estetas", que veem se dedicando a uma espécie de rebaixamento metafísico da cultura puramente visual do grande público adestrado pela mídia correspondente, em nome justamente dos requisitos mais exigentes da alta cultura que no entanto essa mesma massa sequiosa de "beleza" está à procura nos museus. Dá para pressentir que uma tal superposição do vértice e da base da pirâmide cultural acaba comprometendo as alegações de parte à parte. Quem diria, por exemplo, que a atual ressurreição da Estética como disciplina mental autônoma, compartilhasse sua aspiração de máxima depuração da sensibilidade com o mais recente, e enquadrado, gosto de massa pelas blockbuster exhibitions? Tal é a precária e acanhada situação de compadrio das fine arts com a estetização visual predominante na cultura de massa. ${ }^{9}$ Vão na mesma direção as reflexões de Fredric Jameson sobre o caráter reativo do atual retorno ao específico estético, que parece querer forçar sua volta à cena deslavadamente conspurcada da condição dita pós-moderna - e ainda por cima na companhia de outros retornos não menos equívocos como a "ética", a "sociedade civil", a "filosofia" etc. E para variar,

9. Na boa observação de Julian Stallabrass, Gargantua - Manufactured mass culture, London: Verso, 1996, p. 5. Não que a distância entre "alta" e "baixa" cultura tenha se tornado inoperante ou simplesmente deixado de existir, como pretende a fraseologia pós-moderna. A distinção entre uma e outra esfera não só se mantém, como ambas não são autônomas, reagindo uma à outra, a ponto de tal envolvimento recíproco ter se tornado crucial "for the creation of importants forms of aesthetic and monetary use" (p.4). Assim sendo, "much high art is resigned to its restricted role and much of the sophisticated and obfuscating theory wich supports it provides screens to conceal its powerlessness to do anything but generate money" (p.6). uma resposta ressentida (por pura incompreensão) à estetização generalizada da experiência social corrente, colonizada pelo império da cultura visual. ${ }^{10}$ Não deixa de ter sua graça ver essa retórica genérica acerca da necessidade e do valor da arte e da experiência estética hoje, coroar a demanda espontânea (como duvidar?) das ruas pela cultura reservada dos experts e sua clientela "sexy", cuja fome de transcendência ninguém pode legitimamente por em questão nesta Era Comercial.

A corrida do ouro cultural não faz portanto distinções de classe. Ou melhor, parece amalgamar o alto e o baixo numa liga de tirar o sono. Mas ainda estamos devendo a outra metade da resposta à pergunta: o que querem as pessoas quando acorrem em massa aos museus embandeirados? Como lembrado linhas atrás, nosso teórico atualmente na berlinda - o mesmo Andreas Huyssen que andou mapeando o pós-moderno no início dos anos 80 - não disse tudo ao destacar o inconformismo dos novos públicos com a pantagruélica dieta visual que lhes dispen-

10. Cf. Fredric Jameson, "Transformations of the image in Postmodernity", in The Cultural Turn - Selected Writings on the Postmodern, 19831998, London: Verso, 1998. Será preciso frisar? Nada tem a ver esse passe de armas com os paladinos da high culture na América e no Continente e o correspondente revival do juízo de gosto e suas faculdades ocultas, com o inventário da "ideologia da estética" feito por Terry Eagleton (Rio de Janeiro: Jorge Zahar, 1993). No primeiro caso, o grão de ervilha sob o colchão dos novos amigos da arte vem a ser a maldição que parece condenar as questões de estética ao horizonte raso da luta cultural; ao passo que no segundo, a constatação de que a "cultura" se tornou a categoria-chave para a compreensão da sociedade capitalista tardia, se por um lado confirma a percepção de que a "persistência teórica do estético" pode não ser mais do que uma fabulação compensatória própria de um período histórico em que a prática cultural foi rebaixada à condição de ramo da produção generalizada de mercadorias, por outro lado, e principalmente, não deixa de ser uma glosa tipicamente "moderna" do mais "moderno" dos diagnósticos de época hegeliano, a saber: que a Estética só pode levantar vôo sobre o terreno minado da Arte em processo de dissolução por ter esta perdido irremediavelmente sua inquestionável e perene relevância social, de sorte que à crescente crispação da primeira se contrapõe à progressiva redução da segunda ao mínimo denominador cultural. 
sa a indústria cultural - no que finalmente se reconciliariam com os apóstolos da Grande Arte. Faltou acrescentar que na opinião do Autor - aliás, uma legião deles -, vivemos numa Kulturgesellschaft, numa sociedade na qual a experiência e a prática culturais se tornaram a principal fonte ou "agência" (outra palavra chave do jargão) socializadora, ao contrário das macroidentidades herdadas da finada Era Industrial, como o Estado, a sociedade nacional, os partidos políticos, a relação salarial etc. Assim sendo, é natural que as novas funções dos museus privilegiem tais "agentes culturais" - sem tirar nem por, "culturetes" do alto e do baixo clero, na exata medida em que "a cultura dos museus e das exposições possibilitam um terreno que pode oferecer múltiplas narrativas de significados”, estariam "ávidos para ouvir e ver outras histórias, por ouvir e ver as estórias dos outros", e por isso andam em fila indiana, na certa "redescrevendo" (como se diz no vocabulário do neopragmatismo americano) as respectivas identidades por meio de incontáveis "negociações" de imagem.

A esta altura vale o lembrete, aliás quase inútil. A cultura (com ou sem maiúscula, no singular ou no plural) não só ascendeu aos céus do alto consumo, como se converteu no grande lugar comum da vida ideológica contemporânea, enquanto fundamento último da explicação sociológica, sem embargo da Sociologia ter passado de vez desta para melhor - não é que lastimemos o passamento de uma disciplina que se findou com o colapso da modernização burguesa e seu elenco de papéis, funções, integrações etc. Simplesmente será permitido algum ceticismo quanto à vantagem na substituição do velho funcionalismo sistêmico pelo novo mito da sociedade puro movimento browniano de mônadas emissoras e receptoras de significações, isto é, ao contrário dos clássicos, janelas culturais abertas de par em par. Nos termos desse novo senso comum, a extensão que estamos testemunhando da forma-moda a domínios outrora imaculados - como agora o da cultura que se dizia superior ao tempo em que a arte burguesa hipostasiada se contrapunha ao mundo subalterno da reprodução material: quer dizer, antes de tudo, que a famigerada sociedade de consumo tornou-se integralmente cultural, ou seja, quem não consome não se comunica nem transaciona bens e serviços simbólicos, que por isso mesmo são trocados e consumidos para demarcar diferenças e transmitir mensagens. Pelo menos é o que se pode ler na literatura corrente.

Entendamo-nos. Não se deve é claro caluniar abstratamente o consumo. Mas tampouco esquecer que na produção que se baseia no capital, não há consumo que não seja mediado pela autonomização do valor de troca. E por aí vamos: and down we went. Exemplo: na opinião de um renomado pensador latino-americano, o consumo estaria atravessando hoje uma "fantástica revolução cultural", prova disso os verdadeiros conhecimentos de especialista demonstrados por qualquer menino pobre de periferia, que "sabe perfeitamente que roupa vestir, que música quer ouvir e que programa de televisão quer assistir"(FSP, 19.11.95). Suave milagre: com certeza o primeiro consumidor soberano a dispensar os serviços redundantes da publicidade que mesmo assim ainda teima em persuadi-lo a ir de encontro às suas verdadeiras necessidades, exponenciando inutilmente as despesas de venda a serem deduzidas da margem de lucro. Esse o castelo de areia a que se resume a fraseologia corrente acerca da sociedade de consumo. De fato mesmo, a indigitada sociedade de consumo exprime os últimos lances de colonização integral das esferas da circulação, dos serviços e da reprodução por 
enormes massas de capital à procura da valorização que já não conseguem mais nos domínios tradicionais da produção de mercadorias. Justamente a essa industrialização generalizada e universal - o consumidor é ele mesmo uma subjetividade manufaturada - também se costuma dar o nome de sociedade pós-industrial, talvez no intuito de demonstrar que a vida ideológica anda mesmo com as bolas trocadas.

De volta à de fato surpreendente atração exercida atualmente pela cultura de elite sobre as pessoas comuns, iremos nos defrontar enfim com um não menos revelador quadro de linhas cruzadas. Como acabamos de verificar - e manda ver a nova Teoria -, definitivamente uma fila quilométrica na boca de uma megaexposição montada num museu devidamente requalificado pode ser tudo menos um símile - infamante, por certo - de uma esteira fordista de carne enlatada; sobretudo essa nova fase de consumo cultural não poderia mais ser vista sob o ângulo rebaixado da produção padronizada de artigos de comércio, no fundo uma visão moral ressentida de um mundo no qual se assiste finalmente à reconciliação da alta cultura e do mercado. E assim sendo, entre outras consequências, hegemonia cultural hoje não se assemelha mais a uma fábrica hierarquizada produtora de ilusões e consensos extorquidos, decorre pelo contrário de um sistema altamente diferenciado de interações de mão dupla. Uma hegemonia flexível enfim, na qual se exprime a revolução cultural do nosso tempo, a elevação do consumo de massas às altas paragens do espírito. No toma-lá-dá-cá dos novos jogos de hegemonia devemos incluir por certo esta ênfase redentora no rol dos serviços ideológicos prestados pela novíssima esquerda cultural - simplesmente não dá para imaginar o capital em pessoa se autodenegando sob a alcunha de "sociedade de consumo", ou coisa que o valha igualmente execrada pelos gauchistas dos anos 60, salvo depois de ser informado que a referida enteléquia provou ser essencialmente "cultural" -, não, é claro, uma prestação grosseira qualquer, mas resultado de um esforço de atualização à contracorrente, como se viu, dos preconceitos da velha nova esquerda ou marxismo ocidental, infiltrado este último pela mesma ascese intramundana dos primitivos acumuladores de capital, a ponto de se proibir - pelo menos os mais exaltados daquela finada linhagem - até mesmo o prazer estético, e por óbvia extensão a gratificação imediata do consumo cultural, por isso mesmo sistematicamente frustrado para não se cair na tentação da fruição sem conceito.

Já foi dito que não se deve caluniar abstratamente o consumo. No entanto, a demasia contrária - segundo a qual o consumo conheceria hoje uma verdadeira revolução cultural - é bem mais do que um elogio abstrato, e a muitas vozes. As mais excitadas costumam ser as egressas do marxismo, e não é só no Brasil, onde, é claro, são mais visíveis por se encontrarem no topo retórico, não só do poder de Estado, mas do lazer das novas camadas dominantes, a respeito do qual aliás, o jovem Marx tinha opiniões que somente nos dias de hoje alcançaram plenamente sua verdade: "simples indivíduos efêmeros consumindo-se freneticamente a si mesmos para nada" - sobretudo pela abrangência niveladora, pois descreve tanto, digamos, o vazio acaciano de um professor-banqueiro dedicado à prática sentenciosa dos esportes radicais, quanto o potlach de um traficante do varejo, porque pode virar pó no momento seguinte. O mesmo marxista da velha guarda que recorda aquela frase extraordinária, avisa entretanto que toda rejeição da chamada "sociedade 
de consumo" que vá além da conta - e o limite é a extensão da produção de mercadorias até a ponta dos bens e serviços "civilizacionais" - volta os ponteiros do relógio. É que nesse meio tempo o Marx da maturidade havia se tornado por assim dizer progressista, e estava coberto de razão até onde ia o horizonte do capitalismo das duas primeiras revoluções industriais: assim, achava que o ímpeto do capital rumo à forma geral da riqueza estava levando o trabalho para além dos limites de sua mesquinhez natural e portanto criando os elementos materiais para o desenvolvimento de uma "personalidade rica e polifacética", tanto em termos de produção quanto de consumo. Entretanto um primeiro aviso dramático de que o capitalismo havia exaurido sua função civilizadora - essa a base, de que uma ampliação genuína das necessidades seria o corolário fora dado pela crise de entreguerras e o limite absoluto do apocalipse nazista, sinal de alarme anestesiado no entanto pelos trinta anos de expansão do pós-guerra; o atual desmanche chamado globalização voltou a lembrar que a conta final pode ser novamente apresentada. Secado o reservatório civilizacional, sobrou a carcaça da acumulação pela acumulação: o progressismo marxista passou a girar em falso, como se pode verificar na gesticulação economicista dos medalhões supracitados, uma caricatura evolucionista que ora evoca o dinamismo nunca visto do capitalismo, ora a revolução cultural em marcha na diversificação infinita do consumo.

Se ainda restasse alguma dúvida de que estamos lidando com manifestações de um novo establishment, bastaria contrapô-las à reação do antigo diante do mesmo fenômeno, a transformação da cultura dos museus numa atração de massa. Nas palavras escarninhas de um colaborador da New Criterium, parece evidente que alguma coisa absolutamente sem paralelo está ocorrendo quando "quase um milhão de pessoas esperam em filas intermináveis, depois de pagar doze dólares, para estudar os valores cromáticos de Henri Matisse, como aconteceu em 1992 no Museu de Arte Moderna de Nova York"11. A seu ver, descendo mais um degrau na escala do sarcasmo esperável de um cruzado da high culture em campanha contra a degradação promovida pela assim chamada Arte Contemporânea - trata-se de um "verdadeiro milagre democrático", "um elitismo de massa" enfim. É essa "massa elitista" - os quinze milhões de almas que tocam o mundo americano da arte - que o faz espumar, como esperneava nos anos 60 Daniel Bell diante da "massa cultural" responsável pela rotinização e irradiação institucional do primitivo impulso polêmico do Modernismo, que no momento mesmo de sua exaustão se alastrava, "aculturando" a sociedade, doravante irremediavelmente moderna, embora o próprio estivesse bem morto. Não há conservador, de velha ou nova cepa, que se conforme com esse verdadeiro passa-moleque. Só que nessa "massa elitista", onde podemos reconhecer com simpatia nossos culturetes e arteiros desrecalcados pelo novo estágio do consumo cultural, o gosto bisonhamente passadista da New Criterium e consortes enxerga menos ou de modo algum a redenção do consumo pela cultura como fantasiam os culturalistas de todos os quadrantes, do que simplesmente o arrivismo vencedor do establishment rival: "a multinacional que patrocina a exibição bombástica; o crítico que trombeteia a obra; o expert que a autentica; a classe dominante que a compra; a seguradora; o homem que a enquadra e instala (...),

11. Cf. James Gardner, Arte ou lixo?, Rio de Janeiro: Civilização Brasileira, 1996. 
os groupies, os tietes, os snobs (...)" Está claro que não se conforma ante o espetáculo, certamente obsceno, a seus olhos, oferecido por arteiros e culturetes "glamourosos, bronzeados de sol ou elegantemente gordos (sic) como os queridinhos das crônicas sociais (...) o corte perfeito das roupas, os cavanhaques bem tratados, o aroma sofisticado das loções de barba, os bouquets dos perfumes caríssimos", na certa preferindo imaginá-los segundo o estereótipo sentimental costumeiro, mal vestidos, anônimos e prontos. Resta o enigma do apelo de massa que emana desse mundo enfatuado, sem o que a "megaempresa que patrocina a exposição bombástica" dificilmente daria o ar de sua graça, para já ir mencionando o Grande Irmão dessa extensa família global da cultura, ampla o bastante a ponto de abrigar em seu seio generoso antigos irmãos inimigos de esquerda e direita, para falar à moda antiga. A chave, como era de se esperar, deve ser procurada na Arte, miraculosamente desculpabilizada de sua origem de classe numa sociedade antagônica, imemorialmente associada ao aparato da dominação. Mas não é bem nesse supplément d'âme do esbulho econômico que está pensando o nosso detrator, mas nas razões da ascensão meteórica de uma das artes - visuais, ou plásticas, na acepção anglo-americana da palavra "arte" -, em detrimento das demais, relegadas a um obscuro e trivial segundo plano. A arte tornou-se uma senha, uma palavra-de-ordem: "enquanto música e literatura são termos essencialmente neutros (...) a palavra arte vem impregnada de glamour e elevados propósitos. Arte é o aroma de pratos sofisticados do Le Cirque e a ostentação dos apartamentos duplex da Park Avenue. Arte é também o corporativismo dos marchands e curadores (...) Nos museus, a arte é o consolo da classe média. Em mãos de particulares é o estandarte da fortuna oficializada e a primeira aquisição do novo rico". Em suma, a Arte deve ser mesmo "money-sexy-social-climbing-fantastic", nas palavras insuspeitas do antigo diretor do Metropolitan Museum of Art, cujo caminho já cruzamos no início destes prolegômenos à inflação cultural característica da nova era, paradoxalmente uma era de inflação rastejante do lado da economia real. Seja dito de passagem - mas não fora de propósito pois, desenvolvida, a observação nos leva ao âmago do argumento - que essa complacência sem precedentes de que goza a Arte (sempre com maiúscula) não faltou quem a tomasse, juntamente com os demais componentes da máquina cultural contemporânea - da contínua circulação das elites intelectuais ao culto da "criatividade" em todas as áreas do comportamento - como uma das tantas respostas ao surto inflacionário na origem da reversão descendente da onda longa do capitalismo de pós-guerra. Voltando ao nosso detrator da Arte Contemporânea, o que ele está alegando é simplesmente o seguinte: gente de sua laia, por meio das obras de arte, está sempre à procura de Verdade, Beleza ou coisa que o valha, ao passo que o culturete de massa se embasbaca diante de uma paisagem de Cézanne pelo simples fato de ser... Arte. Acresce - encrespando ainda mais a bílis do velho establishment passado para trás - que esse processo de glamourização da arte de amplo espectro mercadológico parece orquestrado pelos herdeiros dos movimentos radicais dos anos 60, está claro que devidamente reabastecidos por sortida literatura pós-estruturalista francesa.

Algumas amostras, provenientes da mesma fonte. "A luta para fazer parte do mundo dos museus é tão grande que o Whitney [palco costumeiro de eventos de arromba] oferece diploma de curador. Nesses cursos superio- 
res, moças e rapazes armados dos textos relevantes de Derrida e Lacan montam exposições para 'questionar a própria noção de exposição’. A arte visual nunca foi tão abertamente ativista como hoje. É raro entramos numa galeria do Soho sem nos depararmos com arte saturada de assuntos. Eles tratam do relacionamento racial, política externa, estupro, Aids e do drama dos desabrigados". "Durante a primavera de 1993, a Escola de Desenho de Parson, um dos maiores do país, ofereceu algo como 'Artistas como ativistas nos anos 90’. O catálogo descrevia o curso como sendo para 'aqueles alunos que questionavam suas vidas através da arte... É mais importante nos unirmos para estabelecer as nossas prioridades do que nos conformarmos com as prioridades dos outros. Tópicos do curso incluem: Performance, Arte de Rua, Efetividade do Pôster, Ação Afirmativa e Apelo por Diversidade no Mundo da Arte. Terminaremos o semestre criando nossa própria ação... Traga para a primeira aula: caderno de desenho que será seu jornal de questionamento e um artigo ou obra de arte sobre um assunto que o afeta diretamente'." “Um artista pode ser ambos, diplomata e revolucionário', disse um risonho e bronzeado Robert Rauschenberg num recente anúncio publicado no New York Times, solicitando dinheiro à classe média alta para uma causa meritória”. Peter Bürger diria que o moço é impermeável ao processo de ressemantização da arte iniciada pela pós-vanguarda uma vez exaurido o ciclo do Alto Modernismo. ${ }^{12}$ Sem blague, seria preciso acrescentar que o passadismo do rapaz, como era de se prever, culmina na Escola de Nova York, com ramificações esforçadas até o

12. Cf. "O declínio da Era Moderna”, Novos Estudos, São Paulo, Cebrap n.20, 1988.
Minimalismo ("enriqueceu nossa cultura visual"). O que ele todavia não vê - muito menos ainda a esquerda cultural americana -, obcecado com a ameaça à autonomia da cultura superior, vinda da algazarra politicamente correta da Arte Contemporânea, é que esta última nem por isto abdicou de nenhuma das prerrogativas de superioridade cultural, herdadas justamente da entronização social da vanguarda americana do período anterior, vanguarda, é claro, na acepção bem magra de Clement Greenberg. Não viu portanto, para além da divergência fisionômica entre os dois momentos artísticos e os correspondentes estilos de consumo cultural de seus animadores, a continuidade histórica entre ambos os períodos, no fundo solidários no mesmo ímpeto de pacificação social que desarmou, sem nenhuma violência interna, o ânimo antagônico sobrante das vanguardas quando Nova York finalmente converteu-se na metrópole geopolítica da arte internacional. Algo como um irresistível "apelo existencial e social" irradiava do "acting out" característico do expressionismo abstrato, do conflito metafísico projetado na textura elegantemente conflagrada de uma tela monocromática saudada como um acontecimento artístico, da convivência blasé de uma série Pop com o mundo chapado da cultura de massa manufaturada, até alcançar enfim o ativismo chic (na voz do preconceito em pauta) da Arte ONG: outras tantas etapas na glamourização da Arte enquanto tal, sans phrase: restaria então localizar a contraparte material desse processo de estilização ideológica inicialmente em circuito fechado, para talvez atinar com os primeiros elementos de uma economia política da cultura - por que horas de frio sob a neve para verificar pessoalmente os valores cromáticos de Matisse, ou mais recentemente, o efeito de depuração crítica do olhar produzido pelas orto- 
gonais de Mondrian etc.? Para não ficarmos inteiramente no ar, adiantaremos que não são poucos os estudiosos que veriam nesse snobismo de massa o prolongamento legitimador de uma gentrification por definição reservada aos titulares natos de todas as requalificações sociais, não só urbanas, onde tudo começou conforme o fordismo deixava de resistir às pressões inflacionárias da regulação keynesiana em queda livre. Em tempo: nenhuma obra de arte é responsável pela assimilação que a neutraliza, sem falar que Modernidade também quer dizer que não há nada que as classes dominantes não possam absorver, salvo a confissão do seu próprio fiasco histórico; entretanto, tampouco faria sentido dar as costas à "recepção" vindoura de qualquer modo inscrita na "produção" de um valor de uso cuja memória tende a se apagar num valor de uso sucedâneo, quando o valor de uso de um artefato cultural é substituído pelo valor de troca, que por sua vez assume ficticiamente a função de valor de uso - esse o segredo do consumo cultural, de ontem e de hoje, que por isso acabou sendo batizado pela literatura apologética, não sem ironia, involuntária é claro, de "simbólico", pois se consome sempre uma instancia de satisfação substitutiva: por isso finalmente se procura antes de tudo... Arte numa natureza morta de Cézanne, ou na comovente elegância (sic) de uma tela minimalista. Sempre se poderá descarregar o ônus desse total desencontro - a instável leveza de um grafiteiro no loft de um culturete - na falta de relação com o objeto, em si mesmo inocente, até mesmo incompatível com os afetos que parece atrair sem no entanto que seu verdadeiro teor seja sequer percebido. Mesmo assim fica a dúvida, a saber: se não estaria na própria obra a semente de sua futura liquidação social. Veja-se a Marcha da História da Arte segundo Clement Greenberg, a teleologia que sustentou o primeiro ciclo de expansão da moderna arte americana, a direção específica da pintura a caminho de forma e cor sobre tela lisa: primeiro Cézanne, depois o cubismo analítico, a Abstração enfim. Em retrospecto, essa mitologia ascensional também pode ser vista como uma afrouxamento por proximidade crescente de inelutáveis fronteiras imanentes. ${ }^{13}$ Se este envelhecimento do moderno é um fato histórico, não se pode dizer sem mais que o consumidor de formas simbólicas não tem relação com o conteúdo de verdade do objeto de seus afetos, por isso mesmo transfigurado como encarnação imediata da Arte.

Convenhamos que não deixa de ter sua graça ver um paladino das Fine Arts, empoleirado na linha de frente da batalha americana contra a "new incivility", torcer o nariz do ressentimento ante o súbito e elevado apreço do grande público pelos mais insignes valores daquele acervo da cultura visual do ocidente moderno. Por que tanta relutância em reconhecer o milagre desse elitismo de massa? Um milagre sem dúvida, se pensarmos nas convicções do anêmico modernismo inglês - na pessoa de seus primeiros teóricos, Roger Fry e Clive Bell, por exemplo - repassadas tais quais ao breviário estético da idade de ouro da arte americana, a saber: que a revolução cézanneana provocou uma tal transformação do olhar que em consequência cristalizou-se uma separação não menos inapelável entre os titulares de uma nova sensibilidade para as formas significantes e a massa restante dos lamentavelmente embotados, cujo número só tenderia a crescer à medida que a arte se tornaria cada vez mais remota em sua necessária rarefação, concernindo um nú-

13. Para maiores detalhes, cf. o mencionado artigo de Peter Bürger. 
mero cada vez menor de pessoas arcando sozinhas com o fardo civilizador das formas puras. Deu-se então um milagre, a reviravolta que os coleguinhas de Hilton Kramer teimam em considerar um disparate - escarnecendo do distinto público que simplesmente tomou ao pé da letra a boa nova de que os valores cromáticos de Matisse (para continuar no exemplo de partida) são de fato o sal da terra conforme se apregoa no jargão metafísico dos catálogos de galeria. Mas afinal qual a gafe cometida pela legião de culturetes de boa vontade recém convertidos, por exemplo, ao purismo plástico? (Mondrian também ganhou sua megaexposição, com direito a boogie-woogie ao vivo). Já sabemos que se deixaram embasbacar pelo mero apelo da Arte. Cometeram, numa palavra, o pecado mortal do filistinismo cultural. Mas não está aqui a novidade, o que aliás seria trivial, simples caso de aburguesamento numa sociedade de massa. ${ }^{14} \mathrm{O}$ novo filisteu não é o anjo extermi-

14. Uma retificação, sugerida por Perry Anderson (Origens da pósmodernidade. Rio de Janeiro: Zahar, 1999, pp.100-102). Mesmo no tempo em que se costumava lamentar o "aburguesamento" da classe operária do ocidente, o conceito já era pelo menos sociologicamente duvidoso. Se ainda fosse o caso de prolongar-lhe a equívoca sobrevida, seria mais adequado falar então num aburguesamento sem burguesia. Esta última - em sentido estrito - está extinta há pelo menos uma geração. Não que a mobilidade social tenha nivelado o que quer que seja - salvo o baixo nível da própria ordem dominante. Para não falar nos periféricos, os países afluentes continuam tão estratificados quanto antes, porém os enquadramentos morais e psicológicos dos atuais donos da riqueza e do poder já não são mais os mesmos. Desde que o grande desrecalque meiaoito se alastrou pelo conjunto da sociedade - periodizando pelo ângulo oposto - algo como uma desinibição de classe sem precedentes contagiou as camadas dominantes, cuja degradação, na opinião do Autor, é o fenômeno mais notável dos anos 90: princesas starlets e presidentes sem consistência, camas de aluguel nas residências oficiais e anúncios de serviços para assassinos, a disneyzação dos protocolos e a confusão das práticas, os sôfregos cortejos pelos subterrâneos noturnos ou pela guarda oficial. Em cenas como essas está muito do pano social do pós-moderno"(p.102). Digamos, desviando em nossa direção o arremate do argumento, que a ressaca cultural na qual se resolve a decomposição das classes dominantes - no lugar do cenário burguês herdado, "um aquário de formas flutuantes, evanescentes (...) funções de um universo monetário que não conhece rigidez social ou identidades fixas" (p.101) - é o que resulta quando desaparece, sem qualquer vitória, o velho adversário da estética antiburguesa. nador do clichê romântico, sopesando na mesma balança utilitária as produções do espírito e o pedaço de queijo do eternamente difamado embora honesto proprietário do não menos mítico armazém de secos e molhados. Mas o tipo igualmente clássico, e nem por isso menos execrado, o "filisteu da cultura", hoje culturete.

Consta que o termo - "filisteu da cultura" - remonta a uma das Considerações intempestivas de Nietzsche, o qual pelo menos se vangloriava não só de tê-lo forjado mas fulminado mortalmente sua primeira vítima, um veteranojá meio apagado das primeiras escaramuças teológicas entre os herdeiros da escola hegeliana, David Friedrich Strauss. A fórmula é de fato eficaz, porém já nasceu sob o signo do equívoco: o filisteu cultivado não surgiu pela primeira vez nas tímidas rodas voltaireanas de pequeno-burgueses alemães, porém muito antes, mais exatamente em certos círculos também alemães - de consumo cultural mais sofisticado, como se diria hoje nos Suplementos -, nos quais, a pretexto de se cultuar nos seus próprios termos monumentais a obra de Goethe, foi aos poucos sendo desfiada uma verdadeira mitologia da personalidade multifacética porque cultivada, superlativamente encarnada pelo próprio Goethe.

Foi mais ou menos essa história que Hannah Arendt principiou a contar desde o seu livro de estreia sobre Rahel Varnhagen: a de uma monumental "sofística da assimilação" a que se entregaram no início do oitocentos judeus e alemães tomados pela ideia fixa do aprimoramento intelectual máximo da própria personalidade como senha de ingresso na "boa sociedade", na verdade trocando di- 
reitos por cultura e alto patrocínio. O caminho é longo até às filas de culturetes siderados pelo sublime oculto numa natureza morta de Morandi - só para variar a amostragem. Mas a categoria é essa mesma: filisteus da cultura, só que agora em massa. É bom notar de saída que não é Hannah Arendt quem está fazendo mau juízo dos novos aficcionados da arte que se dizia séria antigamente - até porque não alcançou o fenômeno e nem mesmo poderia prever o milagre desse último esclarecimento cultural, pois deveria considerar verdadeiramente milagrosa uma tal epifania da beleza duradoura numa sociedade de massas -, mas o defensor da "civility" ameaçada pela ascensão do novo establishment da economia cultural no "turbocapitalismo" americano. No entanto, não é difícil perceber nas suas considerações sobre a crise da cultura na sociedade contemporânea, que a evocação do filisteu da cultura, um fenômeno europeu desconhecido nos Estados Unidos, acostumados até então, em matéria de filistinismo, apenas ao grosso traço ostentatório do mecenato exercido em escala industrial - repercute fortemente nas alegações atuais de uma elite temendo bisonhamente ser desbancada por outros parvenus culturais - receios de tia velha pois na verdade se trata da consolidação de um único bloco.

Pois então: enquanto o mentor de hoje desanca o deslumbramento à caça de qualquer manifestação que traga a chancela suprema da Arte - desde que seja Arte, alguma iluminação profana deverá brotar no corpo a corpo com as obras... de Arte, justamente-, Hannah Arendt nos anos 50 fustigava uma espécie que imaginava em extinção, juntamente com a finada sociedade burguesa de classes, invertendo o raciocínio anterior (na verdade vindouro), embora dizendo a mesma coisa, na sua inocência pré-mo- derna perante o valor de culto da bela aparência do artefato artístico imperecível, invisível a menos de três passos de distância e brilhando bem acima do mundo sublunar da contingência e da reprodução material da vida: agora é a Arte, recoberta por um certo mofo helenizante, que é resservida como antídoto à praga do valor cultural: assim a fome de transcendência que perdura numa maçã de Cézanne - quintessência da capacidade de comover que define a permanência da arte ao longo dos séculos - é enganada por uma espécie de demanda cultural agregada: a arte é antes de tudo Cultura, por isso “vale”. Está claro todavia que o "valor cultural" em jogo na Kulturkampf de hoje era o primeiro e perene atributo que Hannah Arendt contrapunha à "cultura" para a qual o filisteu educado de ontem se julgava predestinado - tal como o culturete de hoje. Dito isso, é preciso no entanto não cometer a injustiça de arrolar a distinção entre arte e cultura, feita por nossa Autora num momento em que o consumo cultural ainda estava engessado pela rigidez da compartimentação fordista, no repertório de campanha dos novos Amigos da Arte: mas não é menos verdade que ela não saberia explicar porque afinal os artista "modernos" se rebelaram contra os seus novos protetores "culturais", já que aparência estética e modernidade por definição não poderiam convergir no vocabulário deles, e é precisamente esse antagonismo que inspira sua advertência antifilistina, atenção! arte e cultura não são a mesma coisa. Mas a semente comum dos irmãos inimigos, os libertários do consumo cultural e a arenga da Alta Cultura como fator de aprimoramento civilizacional já estava lá. Só não dava para prever uma nova rodada em que, graças à intermediação massiva dos culturetes, a arte contemporânea se reconciliaria com os seus protetores na boa sociedade. 
De sorte que, soterrada a sociedade de classes e sua divisão cultural sob um novo regime de acumulação, tudo se passa como se os filisteus da cultura se reapresentassem mas agora como uma paródia da classe universal, enfim o milagre cultural do elitismo de massa. Nestas condições soa meio inócuo relembrar (com razão) que Arte e Cultura não são a mesma coisa, sobretudo depois dos modernos, cuja ruptura aliás também consistiu, graças é claro ao toque subversivo da forma, na promoção artística da mera cultura, pré-capitalista inclusive, sempre na louvável intenção de apressar a bancarrota da civilização burguesa - o que de fato ocorreu, recobrindo as ruínas da Arte com a garoa fina do glamour de uma restauração estética que finalmente encontrou seu destinatário.

Uma observação anterior caminhava nessa direção: “O 'consumo da cultura' é portanto um dado objetivo do capitalismo hoje, uma inércia aparentemente incontornável (...) responsável em última instância pela tão celebrada convergência da cultura dita superior e suas manifestações industrializadas: não há mais distância alguma entre a procura em massa por uma gratificação narcísica no ato de consumir um estilo de vida e a atual abordagem highbrow da tradição cultural, pois eliminada a antiga mediação da forma que garantia objetividade e recuo crítico, um ego análogo ao do público pop assimila a 'obra' como uma atividade de autotransformação, como quem adota, ou melhor adquire, um novo vocabulário com o qual se redescrever em sua identidade expandida"15. Na "atual abordagem highbrow da tradição cultural" convidamos o leitor a incluir, por exemplo, a atual guinada da filosofia

15. Otília B. F. Arantes, “Cultura da cidade, animação sem frase”, Urbanismo em fim de linha, São Paulo: EDUSP, 1998, p.155. americana, na pessoa de um dos seus principais representantes, Richard Rorty, que há pelo menos duas décadas recomenda a seus colegas a urgente transformação da filosofia numa livre "conversação" sobre cultura enquanto repertório de códigos variáveis (o contrário pecaria por "essencialismo") disponíveis para autoedificação - uma hora se é Nabokov, noutra nos vemos no espelho do Prof. Wittgenstein -, uma espécie de decalque arrevesado da arquiduvidosa mitologia mandarinesca da Bildung, justamente o ponto cego identificado pela jovem Hannah Arendt na origem do filistinismo cultural, que hoje voltou a conhecer uma nova primavera de epicentro não por acaso americano. Todavia o fermento é de procedência sobretudo francesa, onde de fato o culturel foi inventado conforme transcorria a crise do consenso keynesiano ao longo dos anos 70, até ser "resolvida" trocando-se equidade por reestruturação produtiva - e com perdão do reducionismo, direitos por cultura. Em tempo: troca funesta aos olhos de Hannah Arendt, que a cada rodada ia se afunilando, primeiro Imperialismo, finalmente a ordem concentracionária terminal.

Voltando: boa ocasião então - a propósito de aclimatação americana da Ideologia Francesa depois de maio de 68 - para ir adiantando o vínculo entre generalização do novo filistinismo cultural e o primado urbano da gentrification, a matriz prática original da ressaca cultural que está nos interessando identificar; ocasião também para destacar uma observação certeira do mesmo Andreas Huyssen que se converteria pouco depois ao ilusionismo da Kulturgeselschaft, no artigo que todos lemos na New German Critique de 1984, "Mapeando o pós-moderno", juntamente com o ensaio pioneiro de Jameson na New Left Review ("Pós-modernismo. A lógica cultural do ca- 
pitalismo avançado"), quando chegava à periferia a boa nova de que a Idade Moderna havia acabado, como se a crise da dívida não estivesse anunciando a mesma coisa só que com o sinal trocado, o que não impedia que nos encontrássemos todos na contramão - ideólogos e perdedores do ciclo anterior. Trata-se da distinção entre plaisir e jouissance feita por Roland Barthes no Prazer do Texto, cuja tradução americana de 1975 inauguraria uma carreira de sucesso num ambiente ideológico até então remoto para um maître-penseur parisiense, no qual entretanto viria finalmente alcançar sua verdade. Na conceituação de há pouco não haverá nenhuma surpresa se encontrarmos Barthes entronizado no santuário do perfeito filisteu da cultura, personagem que desabrocharia na década seguinte. Segundo Huyssen, a jouissance, preconizada pelo Mestre seria uma espécie de "nouvelle cuisine do prazer estético”. Impossível não pressagiar que essa "práxis de mandarim" (nas modestas palavras do Mestre) exigia um cenário à altura. "A eufórica apropriação norte-americana da jouissance de Barthes afirma-se no gozo, semelhante ao dos yuppies de 1984, dos prazeres do connoisseurisme da escrita e da gentrification pelo texto. Talvez por isso Barthes tenha tocado cordas sensíveis da universidade americana dos tempos de Reagan, convertendo-se no filho favorito que abandonou o radicalismo anterior e voltou a abraçar os requintados prazeres da vida, quer dizer, do texto". ${ }^{16}$ Veremos essa mágica decantada pela aclimatação americana, - a "transformação do esterco da desilusão política pós-68 no ouro da felicidade estética" - ir aos poucos fazendo sistema: e não se

16. Texto cit., in Heloisa Buarque de Holanda, org., Pós-Moderno e Política, Rio de Janeiro: Rocco, 1991, p.67. trata apenas de relembrar que os desmobilizados de Maio postos em disponibilidade ideológica forneceram os primeiros fogos de artifício para celebrar o cultural turn do capitalismo, mas também entender que essa operação não teria a menor chance de sucesso caso não fosse correspondida por um movimento análogo no mundo dos negócios que por sua vez se glamourizava. Aqui o chão histórico dos processos de gentrification, como a seu tempo verificaremos, sempre lembrando que o foco original da nova sensibilidade cultural deve ser procurado antes de tudo na metamorfose de fundo da experiência material urbana, enfim as razões da paisagem. ${ }^{17}$

Em princípio as alegações culturais daquela primitiva sofística da assimilação quando muito concerniam apenas um grupo específico de outsiders, muito embora a barganha social que eles estilizavam fosse por isso mesmo a condensação emblemática da própria capitulação política da burguesia alemã na pessoa de seus representantes nas altas esferas do mandarinato artístico e intelectual. O então nascente filistinismo cultural não prosperaria sem essa dissociação entre a existência imaginada e a impotência social, aliás consentida, no caso daquele limiar histórico que está nos servindo de referência. Sabemos como tal capitulação se converteu em simbiose coroada pelo sucesso econômico

17. Como ainda daremos algumas voltas antes de abordar o tópico gentrification, pelo sim pelo não, vale o lembrete sumário, inclusive para situar as alusões anteriores ao termo, por exemplo no resumo de Mike Featherstone: "reestruturação global das relações socioespaciais mediante novos padrões de investimento que acabam promovendo algumas tendências contrárias à descentralização urbana através do redesenvolvimento das áreas centrais. Esse processo supõe a desindustrialização das áreas urbanas centrais, que são reocupadas por membros da nova classe média e desenvolvidas como locais de turismo e consumo cultural. Ao mesmo tempo, a classe trabalhadora e os pobres, que anteriormente residiam nessas áreas, são expulsos ou encaminhados a outros redutos", Cultura de Consumo e PósModernismo, São Paulo, Studio Nobel, 1995, p.150. 
do auge imperialista, sempre de um lado a vida do espírito em permanente escalada - quanto mais profunda sua "interioridade" maior a impregnação pelos ritos hierárquicos da boa sociedade -, do outro, o livre curso dos negócios, intocado, e recalcado, como era do dever de almas de elite - e negócios pesados, entre a alta finança e os donos do poder, às costas dos esbulhados de sempre. Ocorre que estes se levantaram na primeira grande crise sistêmica moderna, a de entreguerras. O desfecho é conhecido, além de sinistro, e por isso mesmo interessa recapitular num momento em que os mesmos ingredientes estão se reapresentando. Pela primeira vez - e nas condições previstas pelos clássicos - o capitalismo chegara à beira de uma ruptura. Sabemos qual a resposta fascista à Grande Depressão - melhor dizendo, como o big business por assim dizer terceirizou os serviços políticos de que carecia, entregando-os a operadores especializados em marketing de massa, aliás os seus inventores. Os chefões nazistas do crime político organizado - foi o primeiro laboratório de uma global criminal economy -, se encarregaram de canalizar o desrecalque das populações consumidas pelo ódio característico da impotência ante a dominação absoluta, cuja experiência acabavam de fazer na guerra, e logo depois quando desemprego e hiperinflação se juntaram para o serviço sujo da desvalorização, como é da lógica de um sistema demente de acumulação interminável - revelação que àquela altura deitou por terra também os últimos vestígios do progressismo que porventura ainda impregnassem, e abasteceram durante dois séculos, as mais diversas filosofias da história, sobretudo materialistas. $^{18}$

18. Hoje somente um amálgama aberrante que se poderia denominar marxismo de classe dominante - original contribuição nacional ao museu de cera mundial das ideologias - continua dando voltas ao realejo do
Brecht, como se há de recordar, procurou expor à execração divertida das vítimas as novas afinidades eletivas que despontavam: para melhor ressaltar a crapulização da elite dirigente, aburguesou o lumpen e conferiu envergadura shakespereana a gangsters pequeno-burgueses - a propósito, veja-se ainda a contribuição dos bêbados de Mahagony ao debate contemporâneo acerca do valor artístico, arrebatados pelo jogo esmerado do pianista, ao que parece sóbrio: “ah! a arte, essa é a eterna Arte!” Nos termos já referidos, seria o caso de acrescentar que a jouissance mandarinesca dos filisteus da cultura, cuja intensidade aumenta de acordo com a euforia ascensional do alpinismo em sociedades altamente estratificadas, reaparecia agora em chave de massa no raso prazer estético que ralé e elite se ofereciam mutuamente, dando-se uns aos outros em espetáculo. Walter Benjamin por sua vez foi ainda mais diretamente ao ponto que está nos interessando, a saber o destino daquele descompasso entre a sublimação cultural estimulada por toda sorte de mitos compensatórios e a devastação promovida pela reprodução econômica na passagem da antiga sociedade de classes do capitalismo concorrencial em crise para a sociedade de massas do capitalismo em estado avançado de concentração absoluta do poder. Pois bem, aquela desconexão em que se exprimia a ditadura dos mercados socialmente desregulados sobre o metabolismo da sociedade e que culminara na prolongada agonia social dos anos vinte e trinta, encontrou milagrosamente o seu escoadouro natural nunca se louvará demais o talento nato dos grandes chefes

desenvolvimento das forças produtivas, como fonte legitimadora da caça capitalista ao superlucro de sempre. Último e patético capítulo da estupidez progressista da qual Flaubert foi o primeiro a pressentir a apoteose. 
do III Reich para a animação cultural - na estetização da vida, o que não surpreende sendo o próprio Führer antes de tudo um artista e à testa de um país de poetas e pensadores ${ }^{19}$ : "o Fascismo queria organizar as massas, sem mexer no regime de propriedade, o qual todavia elas tendem a rejeitar. Ele pensava solucionar o problema, permitindo às massas, não certamente fazer valer os seus direitos, mas exprimi-los. As massas têm o direito de exigir uma transformação do regime da propriedade; o fascismo quer permitir-lhe que se exprimam, porém conservando o regime. O resultado é que ele tende naturalmente a uma estetização da vida política."20 Qualquer semelhança com o atual êxtase cultural de massas a que não corresponde em absoluto nenhum alívio consistente no front da desgraça econômica planetária, salvo a promessa obviamente fraudulenta de redenção social pela afirmação cultural, não é mera coincidência, a não ser para os culturetes de alto e baixo escalão que à vista do triunfo da vontade estética nos filmes de uma Leni Riefensthal, por exemplo, só podem achar que o prognóstico, de que a onda do futuro é o fascismo, é fruto do ressentimento gerado pelo mal-estar na globalização.

Ainda é cedo para arriscar alguma coisa acerca dessa inegável recorrência sem falar na virada decisiva que

19. Quem viu o notável documentário A Estética da Destruição sobre o horror da Nova Educação Estética da Humanidade segundo os nazis, saberá com precisão do que estamos falando. Salvo por um involuntário senão, que no entanto não é pouca coisa: entusiasmados com a descoberta, os dois cineastas carregam na mão, dando a impressão de que a política de extermínio das populações inúteis para o aparato de dominação social talvez se devesse a algo como uma paranoia estetizante, derradeiro e involuntário tributo ao mito dos poderes encantatórios da Aparência Estética.

20. Walter Benjamin, "A Obra de Arte na Era de sua Reprodução Técnica", Epílogo. consistiu - no outro lado do Atlântico, na América rooseweltiana às voltas com a mesma crise - na conversão do aparato tecnológico do espetáculo da propaganda política num ramo estratégico dos negócios industriais. Há mais, todavia, ainda no plano das simetrias: segundo Benjamin, a resposta da esquerda à estetização do antagonismo social deveria ser ainda e sempre mais politização da arte. Ora, em meio ao caos sistêmico de hoje, impulsionado mais uma vez pela autonomização do processo de valorização - o qual, embora cego, como é da natureza dos sistemas de dominação, sempre discrimina com instinto seguro os vencedores de turno e os perdedores de sempre - a novíssima esquerda parece responder simplesmente redobrando a aposta do establishment - para este sem dúvida um negócio da China - na apoteose da cultura e o concomitante fim da política: ou melhor, esta última tornou-se enfaticamente cultural desde o momento em que se convencionou - não se sabe bem com quem - deixar a economia intocada, correndo livremente em faixa própria, quando muito sujeita a emendas decorrentes da mera gestão dos interesses consolidados.

Seja como for, pode-se dizer desde logo sem nenhum exagero que as várias contribuições para o Pensamento Único $^{21}$ que atualmente enlaça dinheiristas e culturalis-

21. O leitor terá sem dúvida reparado que a expressão "pensamento único" comparece em nota de rodapé na abertura deste estudo, sugerindo algo como uma matriz conceitual comum na origem do que se convencionou chamar de "planejamento urbano estratégico", a tal ponto "comum" (mas ainda não generalizado no grau ótimo imaginado por seus promotores) que se poderia dizer - como de fato é dito noutros termos no artigo já citado da revista Veredas-que no fundo as cidades em competição pelo investimento escasso no sistema mundial não pensam em outra coisa, e num jargão inconfundível que a seu tempo analisaremos de perto, e isso à revelia das preferências políticoideológicas dos administradores de turno. A esse conjunto de ideias fixas uma espécie de catecismo básico do economicamente correto, martelado pela mídia, propagado pelas grandes corporações de negócios, dos quais a referida 
tas também se exprime no reforço digamos teórico de algo como um arrivismo universal embora paradoxal pois se desenrolando num mundo em que a mobilidade social se reverteu sem apelação. No que concerne então o filistinismo cultural generalizado característico da nova sofística da assimilação - todos batem à porta mas ninguém será chamado - deu-se então uma singular divisão de trabalho: como sugerido, a nova direita contribuiu com uma "gentrificação da teoria", já que lhe toca por natureza os assuntos de elite numa sociedade enfim comandada pelos melhores e mais inteligentes, cabendo aos ativistas do outro lado do balcão realçar o caráter libertário do consumo cultural. Assim, do capitalista cultural que, no legítimo exercício de suas funções de high culture, proclama que a arte é 'money-sexy-social-climbing-fantastic, ao cocota da néo-favela embalado da cabeça aos pés por retalhos de grife (veja o leitor, no extraordinário romance de Paulo

mídia éum dos ramos mais prósperos, e confessado enfim por todos os políticos relevantes na arena global do poder - o jornalista Ignacio Ramonet deu o nome de "pensamento único", no editorial do Le Monde Dimplomatique de janeiro de 1995, retomado depois no livro Geopolítica do Caos, Petrópolis; ed. Vozes, col. "zero à esquerda", 1998, pp. 73-75. Tal evangelho da economia de mercado pós-keynesiana é dito "único" não só por ser vedada a recusa-qualquer desvio veleitariamente heterodoxo é punido ato contínuo pelos "mercados" e seus diretórios políticos mundiais -, mas por ter engolido a velha esquerda, que acabou afinal rezando pela mesma cartilha. De nossa parte - por enquanto estamos tentando sugerir que o novo regime da cultura - vista no conjunto de seus negócios, tanto os do mais alto quilate espiritual quanto os mais ostensivamente pragmáticos, mas nem por isso menos prezados, et pour cause nos dias que correm - é parte constitutiva desse novo senso comum, o qual certamente não se pode chamar "pensamento", salvo por escárnio, e já não é mais "ideologia" na acepção clássica do termo, que remonta à Era Liberal-burguesa do capitalismo, digamos à vida mental em tempos de padrão ouro e do imperialismo do livre comércio; quem sabe "propaganda", só que gerada por assim dizer rente ao solo, pela própria "realidade", a qual então não poderá ser "única" como apregoa, pois então estaria dizendo a verdade num mundo obviamente "falso", embora pelos mesmos motivos tal obviedade tenha se tornado invisível, na falta de um teste de realidade sem aspas a que se possa submeter a tal "realidade" única que se tornou sua própria logomarca etc.
Lins, Cidade de Deus, se não é fato que o simpaticíssimo bicho-solto Bené a certa altura contrata os serviços de consultoria de imagem pessoal a um cocota de suas relações, encarregado inclusive de abastecê-lo com os acessórios indispensáveis), passando pelo culturete com ares de instalação ambulante e seu duplo, o arteiro minimalista com visual de operador no mercado financeiro, foi se armando um sistema de vasos comunicantes entre os hierarcas da alta sociedade - robustecidos com o sangue novo dos robber barons compradores de estatais - até os picadeiros de mais baixa categoria em que evoluem as galeras nem por isso menos suntuosamente paramentadas com os respectivos manufaturados culturais; como se ainda fosse necessário confirmar os velhos preconceitos modernistas de um Alfred Loos quanto à associação congênita entre ornamento e delito. Ainda sem muito exagero pode-se dizer que o carrossel inquietante em que gravita a fauna multicolorida que compõe essa massa cultural acabou contaminando com um mesmo ar de família o discurso corrente sobre a sociedade, uma sociedade de indivíduos está claro: todos consomem estilos disso ou daquilo, manejando com a competência requerida operadores simbólicos nos jogos de linguagem a que se resume hoje o toma-lá-dá-cá das trocas sociais. Todavia interessa menos a epistemologia dessa ciência social talhada sob medida para a referida massa cultural a que no fundo se destina, do que a verificação da sintaxe do arrivismo que parece organizar as incontáveis variantes ad hoc desse discurso único. Assimilação a todo custo, sendo a cultura a moeda de troca. Mesmo a elite, hoje em estado acintoso de secessão - esgotadas as virtualidades civilizatórias do capital -, que antes pelo menos ameaçava integrar, mantém um plano de carreira próprio alimentado por doses maciças de fantasias culturais e alto patrocínio. 
Passemos então rapidamente em revista teoria e prática do novo arrivismo por inflação de ativos culturais, começando pelo alto como se disse, no caso, pelos usos e costumes dos vencedores da atual revanche do capital. Como vimos, retomaram com grande acinte e circunstância - como é próprio dos momentos de triunfo - hábitos ancestrais das classes ditas antigamente ociosas. "Antigamente" não está assim tão longe de nós. Basta recordar a simbiose em que culmina a Recherche proustiana, quando Mme. Verdurin finalmente consegue se fazer assimilar pela boa sociedade do faubourg Saint Germain - a camarilha dos consumidores, como dizia Walter Benjamin a propósito dos grandes mundanos de Proust, nos quais a curiosidade detetivesca do escritor via antes de tudo um bando de conspiradores, um clã de malfeitores ${ }^{22}$. Simbiose entre a riqueza nova da burguesia e a máscara mortuária do Antigo Regime, sem a persistência do qual não se entenderia o snobismo - hoje redivivo na ansiedade pelo acesso exclusivo aos santuários artísticos do poder e do dinheiro. ${ }^{23}$ É bom não esquecer que nesta aliança responsável pela fixação das regras pecuniárias do bom gosto não por acaso no auge da predação imperialista - ocasião em que o gentleman e o marginal costumam baralhar seus papéis -, cabia à tribo Verdurin entrar com a sofística nossa conhecida do filistinismo cultural - também num período de apogeu -, na qual a patronne era imbatível,

22. Walter Benjamin, "Para um retrato de Proust".

23. Não se deve esquecer nestas horas de verificar a observação de Adorno: o poder inescrutável concentrado nos senhores do Castelo acaba convertendo o agrimensor sem nome, e sempre barrado, num snob. "Anotações sobre Kafka", in Prismas, ed.cit., p. 246. Aliás uma observação que só ganha sentido à luz das considerações finais de Günther Anders acerca das muitas estilizações do superpoder em Kafka, cf. Kafka pró e contra, São Paulo: Perspectiva, 1971. uma sensitiva a quem um simples trecho do Beethoven do último período podia derrubar com uma enxaqueca estética de vários dias. E isto sem falar que, sendo dreyfusard para ainda melhor se distinguir dos chatos do faubourg, o salão era politicamente correto. Como a sociedade era de classes e antagônica, ficavam de fora os que "moem no aspro" - embora constituíssem o ponto de fuga da construção literária proustiana. Em escala planetária, aquela camarilha está de volta - além do mais, organizada na forma de networks, o que lhe aumenta o charme sociológico. E com ela, como era de se prever, o domínio da alta finança, e tudo o mais que daí se segue em matéria de consumo ostentatório, cuja estilística, por assim dizer, se propaga agora como um snobismo de arrastão. Pelo menos desde o tempo em que Proust o elevou à categoria chave de um diagnóstico de época tão fulminante quanto um juízo final, o snobismo apresenta duas dimensões fundamentais: uma regida pela lógica exclusiva de todos os círculos de poder, o código binário do in e do out e a correspondente ansiedade da inclusão; a outra, mais profunda e determinante, tem a ver justamente com a arte daqueles exímios profissionais do consumo, a arte de apagar, até o menor vestígio comprometedor, qualquer vínculo com o mundo suspeito da produção - ainda na luminosa observação de Walter Benjamin, tudo se passa como se as altas rodas do poder e do dinheiro admitissem qualquer afronta em matéria de desengano: que se desmanchem as ilusões de classe acerca do Eu, do Amor ou da Moral, desde que não se levante o véu que recobre o mistério econômico, desde que não se tenha o mau gosto de aludir a atividades baixamente aquisitivas e lucrativas. Numa palavra, desde que se estetize a riqueza escamoteando a sua fonte - como sabe aliás qualquer leitor dos romances "transatlânticos" de 
Henry James, nos quais invariavelmente um milionário americano cruza o oceano, quando não se expatria de vez, à procura do cenário apropriado para a transfiguração estética de uma fortuna cuja origem vulgar o acabrunha. ${ }^{\mathbf{2 4}}$ (Hoje o mecenato industrializado dispensa aquela travessia, o exercício da alta cultura, como se diz no jargão empresarial, faz tempo que se pode fazer em casa, embora o capital continue acumulando em casa alheia.) Em matéria de estetização das relações sociais de produção estamos portanto na origem do nosso tempo.

Já vimos no que deu o próximo passo dessa estetização do dinheiro, cuja origem quanto mais camuflada mais estilo e distância aurática imprime à coreografia dos senhores: o pequeno grande mundo dos snobs proustianos, desaparecido com a Grande Guerra, reapareceu na sociedade nazi do espetáculo, cuja violência deflagrada ato contínuo visava igualmente deixar num limbo mitológico a raiz econômica da desgraça coletiva. Aqui porém uma primeira metamorfose decisiva. A espetacularização da política autorizava os chefes fascistas a oferecer sem risco aos seus financiadores o luxo ideológico de levantar enfim o véu do segredo econômico, o mistério fabuloso da supremacia social dos elegantes, por isso mesmo impiedosos, para recobri-lo é claro com um outro ainda mais espesso e misterioso. Nunca será demais relembrar: permitir às massas que se exprimam - dos cortejos e comícios gigantescos à guerra, passando pelos megaespetáculos esportivos e expedições punitivas -, sem que se toque no âmago da rapina que vem a ser o sistema econômico, quer dizer,

24. "Uma riqueza agora dúctil obediente a uma destinação, a um pensamento artístico, ouro maleável, poeticamente cinzelado e que sabe sorrir", Marcel Proust, À sombra das raparigas em flor, trad. Mário Quintana, Porto Alegre: Globo, 1973, p.169. entre tantas outras manobras da propaganda a que enfim se resumiu a ideologia, caluniar a circulação econômica responsabilizando-a pelo inteiro mecanismo da exploração - os prejudicados só sabem dela no momento de ir às compras - na pessoa de um bode expiatório sobre o qual é descarregada a injustiça sofrida por aqueles que a dominação na produção mutilou e de que ela se serve para a sua perpetuação, mais uma vez, oferecendo-se em espetáculo o extermínio dos expoentes designados do poder do dinheiro, primeiro em efígie e logo mais nas fábricas da morte em que culmina a estética da destruição. Esse o fundamento especificamente econômico do antissemitismo burguês segundo Adorno e Horkheimer, o mistério econômico impunemente desvendado do porte aristocrático-prussiano dos mandantes do crime, a camarilha dos consumidores na sua hora da verdade; avesso, igualmente exposto à luz dos holofotes, do pathos metafísico com que se elevou o capitalismo enquanto crime organizado à condição de capítulo inaugural na História do Ser. Delegou-se assim à frustração permanente das massas, teatralizadas pela indústria cultural nazi, a quebra do decoro pecuniário das elites. Eis o passo profético, inclusive quanto ao destino da rebelião das massas e a afetação cultural das elites: uma sociedade em que finalmente tudo está à venda, até mesmo a palavra que a desmascara - parodiando cinicamente a crítica que nesse meio tempo foi se tornando redundante à medida em que o fiasco da ordem liberal se tornara um apelo ao desrecalque - "se legitima por isso mesmo como recomendação para a admissão no banditismo político; essa sociedade, na qual a política não é apenas um negócio, mas o negócio é a política inteira - pois essa sociedade se toma de indignação contra o retrógrado mercantilismo do judeu e designa-o como materialista, o tra- 
ficante, que deve recuar diante do fogo sagrado daqueles que erigiram o negócio em algo absoluto"25. A que ponto chegamos, como aos poucos estamos vendo: a palavra crítica continua girando em falso, pois quanto mais se deixa entrever dos bastidores, tanto mais se legitimam os negócios; a indignação com o mercantilismo, hoje novamente uma política de Estado, tornou-se ela mesma retrógrada, enquanto o "fogo sagrado daqueles que erigiram o negócio em algo absoluto" arde atualmente nos templos da Alta Cultura, à porta dos quais as filas dão voltas e os críticos culturais preparam o espírito para a matéria que enviarão aos suplementos da grande imprensa de negócios.

Agora, entre outros deslocamentos ciclópicos, o snobismo das classes ociosas do tempo de Proust e Veblen - que hoje preferem fantasiar sua existência como uma nova gentry - tornou-se um logro de massa, como se pode verificar pela sofística assimilacionista da indústria cultural, também ela, como outrora os virtuoses do consumo, estrategicamente empenhada em propagar o mito do consumo aliviado do fardo da produção num momento em que a fragmentação das cadeias produtivas globais generalizou e intensificou o emprego podre, o trabalho penoso e a remuneração degradada, ilusionismo contemporâneo e rigorosamente simétrico deste outro mais clássico - cuja força persuasiva também se intensifica em tempos de financeirização da riqueza -, que consiste na miragem do dinheiro rendendo juros com a naturalidade com que a pereira pode produzir peras. De quebra, ao anexar as jazidas petrolíferas da Grande Arte que em princípio anima todo artefato cultural contanto que seja "autêntico", a in-

25. Adorno e Horkheimer, Dialética do Esclarecimento, Rio de Janeiro: Zahar, 1985, pp. 161-162. dústria do autoengano encontrou no culturete o consumidor perfeito, cujo êxtase estético, empresariado por quem de direito, reforça por sua vez a fantasmagoria da economia desmaterializada. Há mais todavia, no que se refere aos deslocamentos de época em relação à matriz original que está nos servindo de termo de comparação. Como logo se verá e já não é mais nenhuma surpresa a esta altura do argumento, a estetização do dinheiro, de manto encobridor ricamente ornamentado passou a ser exposta e enunciada como tal numa imensa vitrine de aparato - a vitrine do alto patrocínio, por exemplo -, assim como os complicados exercícios de hipocrisia do snobismo de classe foram engolidos pela desenvoltura cínica da atual elite do poder, como alerta a imortal declaração de princípios do perfeito consumidor cultural, mais uma vez: "Art is money-sexy-social-climbing-fantastic!" Aqui o outro deslocamento característico dos novos tempos. O antigo virtuose do consumo estilizado não está mais sozinho nessa escalada fantástica, ganhou por assim dizer uma clientela de massa, como vimos, a "massa cultural" identificada pelos neoconservadores inquietos com o rumo das contradições culturais do capitalismo depois das turbulências do modernismo realmente existente desde os anos sessenta - está claro que Daniel Bell, autor da expressão, e seus colegas dos dois lados do Atlântico não poderiam sequer imaginar que, com as honrosas exceções de praxe e por pura teimosia, os corações veteranos de Maio de 68 em pouco mais de uma década estariam bem instalados no establishment, e mais, sem precisar renegar nada do que escreveram, bastava acompanhar com perfeita coerência a contaminação recíproca, ao longo da Era Reagan/Thatcher, a progressiva convergência entre o estouro libertário meia-oito e as es- 
tratégias empresariais pós-fordistas, como a seu tempo veremos à medida que nos aproximarmos da raiz da convergência entre cultura e dinheiro.

\section{Documentos de cultura, documentos de barbárie*}

\section{O sujeito oculto de um manifesto}

\begin{abstract}
"Quem quer que adote o materialismo histórico precisa encarar com uma certa distância os bens culturais. Pois, tomados em conjunto, como não sentir um calafrio quando pensamos em sua origem? Eles não nasceram unicamente do esforço dos grandes homens que os criaram, mas também da anônima compulsão ao trabalho imposto aos contemporâneos de tais gênios. Não existe nenhum documento de cultura que também não seja um documento de barbárie. E a mesma barbárie que os afeta contamina o processo de sua transmissão." Walter Benjamin, Teses sobre a filosofia da história, n. VII
\end{abstract}

"Quem construiu a Tebas de sete portas? Nos livros estão nomes de reis.

Arrastaram eles os blocos de pedras?"

Bertolt Brecht, Perguntas de um trabalhador que lê

"Amamos a beleza nos limites do juízo político." Péricles, segundo Tucídides

* Publicado originalmente em Cadernos do Folias, grupo Folias d'Arte, São Paulo. 2001. 
Em 1999 foi lançado em São Paulo por um coletivo da classe teatral um Manifesto em favor da Arte e, por isso mesmo, contra a Barbárie. Trata-se de uma declaração destinada a marcar uma posição de esquerda diante da questão cultural no Brasil privatizado de hoje. Por sinal ela mesma, a esquerda, numa situação igualmente dramática. E para tanto contrapunha ao consenso dos integrados algumas verdades desviantes, como a lembrança de que a arte não é um mero produto cultural e que a cultura, por sua vez, não é simples matéria de fomento e patrocínio. Essas certezas não são de agora; a coisa nova e ruim é a Barbárie no meio do caminho e no topo do Manifesto, que aliás distingue muito oportunamente a barbárie oficial da vulgar. Seguindo o conselho clássico, também achei que era o caso de me concentrar na coisa nova e ruim, sem deixar de repisar, porém, as boas e velhas convicções de sempre'.

Um Manifesto contra a Barbárie, e ainda mais em nome da Arte: quem não assinaria em baixo? Esse justamente o problema, e para melhor realçá-lo vou me fazer de desentendido, advogando por alguns minutos a causa do diabo - no caso, os novos organizadores da cultura. Não é preciso muito esforço de imaginação para visualizar a seguinte cena. No velho sistema do abaixo assinado, por exemplo,

1. No que segue, procuro reconstituir o que imagino ter dito, e subentendido, no Teatro Aliança Francesa em 23 de novembro de 1999, além de recorrer a alguns esquemas parcialmente sugeridos num artigo redigido por mim, porém planejado em parceria com Otília Arantes, "Sofística da assimilação", e publicado na revista praga n. 8, 1999. Digitação de Iná Camargo Costa, do Conselho Artístico do Folias D’Arte. uma adesão pedida por telefone, sem muita especificação de conteúdo, solicitada por um recruta inexperiente e, além do mais, por engano, é claro, digamos ao animador sênior da Fundação "O Belo Autônomo”, seria prontamente concedida, também por engano, mais ou menos nos seguintes termos:

“(...) É isso aí. Somente a arte poderá conter a barbárie. Precisamos dar um basta à incivilidade, ao retorno da animalidade, à brutalidade da vida cotidiana. Qual é a ideia por trás de uma Sala São Paulo, por exemplo? Ou do futuro Conservatório Musical Velho DOPS? E, justamente, de caso pensado, em plena cracolândia. O Projeto Luz não seria viável se os seus idealizadores não estivessem convencidos, entre outros tópicos indispensáveis em qualquer reabilitação urbana, como você há de convir, que a música que manifesta os instintos é a mesma que os apazigua. Nós também. Repare na dialética viva de nossa razão social, o belo autônomo. Pois qual é o nosso lema? Romper barreiras, ir até onde as pessoas estão. Por isso também achamos que se deve levar a arte até o coração mesmo da new incivility, como dizem os nossos parceiros americanos, que aliás iniciaram essa cruzada. Veja bem, não só a Grande Arte, não somos passadistas. Como disse, nosso negócio é romper barreiras. Um museu hoje em dia tem que tornar cada vez mais tênue a linha que separa arte, moda, música e outras manifestações culturais. O grande público que hoje acorre em massa às exposições sabe disso. Quase que por instinto ele já sabe que moderno mesmo é ir ao museu. Mas quer dizer então que vocês finalmente se renderam à evidência de que a economia não alicerça uma civilização? Já que vocês estão lançando um Manifesto contra a barbárie, também devem ter chegado à mesma conclusão nossa de que a solução dos problemas 
do país não está na economia, mas na cultura; são os paradigmas culturais que definem as escolhas econômicas. Num país cronicamente inviável - você viu esse filme? um soco no estômago, hein? essa a incivilidade brasileira de nascença que precisamos reverter -, num país assim, meu caro, só a cultura vai poder nos oferecer a garantia de voltarmos vivos para casa depois de um dia de trabalho honesto (p...). Só a cultura artística verdadeiramente civiliza, não é mesmo? Costumo empregar a fórmula: um arremate de raiz, para sugerir essa pacificação dos costumes pelo polimento estético. Por isso nós aqui no "Belo Autônomo" temos um compromisso ético com a função social da arte, sim senhor. Somos pela arte engajada, sim: o que há de mais ético do que a autonomia estética, você não concorda? Agora, tem uma coisa: francamente não entendo muito o preconceito de vocês contra o mercado. Afinal, vamos e venhamos, civilização custa caro! Aliás, deve mesmo custar caro para ter valor. Quem fala em cultura, meu velho, deve aprender que tem de falar em dinheiro. Mas olha, o escrúpulo não é só de vocês, não: a maioria dos nossos empresários ainda tem um senso muito atrofiado de cidadania, só agora eles estão despertando para a missão civilizadora do mecenato corporativo; daí nossa luta para convencer governantes, investidores e sociedade civil que a ética é o principal fator de produção e que a cultura será a economia do próximo século. É isso aí. Claro que assino, e ainda quero vê-los sem restrições, de alma leve, nessa nossa frente ampla da Civilização contra a Barbárie. A propósito, parabéns mesmo pelo novo espaço. Vi outro dia na agenda da Bravo! que um dos grupos do Manifesto está corajosamente inaugurando seu Galpão numa das regiões mais deterioradas do Centro. Faço questão de divulgar no nosso Boletim. Que tal a chamada: mais uma iniciativa a favor da recuperação de uma zona de fronteira? Cá entre nós: dando uma de Exército da Salvação, hein? Isso é coisa de escoteiro, vocês precisam se profissionalizar. Apareçam no Belo.”

(A propósito, um breve flagrante dessa ânsia por civilidade que se apossou da boa sociedade brasileira pode ser visto no filme de Sérgio Bianchi que tanto impressionou o companheiro da "Belo Autônomo", aliás fita na qual se fala de civilização a três por dois. Na observação precisa de um crítico isento: "duas dondocas atropelam mendigos e, em vez de socorrerem as vítimas, produzem discursos bem articulados em que se isentam de culpa. Uma delas é clone de uma socióloga conhecida. Afirma que não tem culpa se o atropelado desrespeitou a lei, que não é possível viver em um país no qual as pessoas não têm a mínima noção de contrato social e, em seguida, se manda, dizendo que não irá perder um compromisso importante por causa de gente como aquela" ${ }^{2}$. Como se sabe, a pontualidade é um dos pilares da civilidade - no Antigo Regime dizia-se que era a polidez dos reis, que salvo pela dita pontualidade não eram propriamente grandes humanistas. Quanto ao compromisso intransferível, o roteiro do filme por certo exigiria que fosse uma palestra dedicada a ensinar os empresários a lidar com a sociedade civil, ou coisa parecida com muita interlocução e parceria, na qual palestra também se explicaria que a sociedade civil é um receptáculo contendo entidades éticas em suspensão, mantidas as atuais condições de temperatura e pressão. Em tempo, o outro lado: Erasmo de Roterdã, autor do mais famoso

2. Luiz Zanin Oricchio, A crônica de um impasse social, OESP, 14.05.2000, p. D6. 
tratado de civilidade da Renascença, certamente gostaria de saber que o código de boas maneiras em vigor entre os internos da FEBEM adverte os recém chegados que arrotar ou expelir gases durante as refeições é punido com a morte.)

Noves fora, como ficamos? Se a ideia era tomar posição à esquerda diante da atual corrosão do caráter nacional, numa incômoda posição em falso. Não me parece um bom negócio para a esquerda fazer da cultura a derradeira trincheira da civilização, sobretudo agora que esse é precisamente o grande negócio da direita. É claro que forcei um pouco a mão na convergência, pelo menos de vocabulário, entre refratários e establishment. Digamos, para nos reconciliar, que tudo se deve a uma vírgula fora de lugar, que aliás nem mesmo deveria existir: uma coisa é um Manifesto contra a Barbárie, em nome da Arte; outra, muito diferente, um Manifesto contra a Barbárie em nome da Arte. Pois é justamente desta última que se trata. Mas então teria sido necessário mudar a linguagem, chamar as coisas pelo seu verdadeiro nome, ou pelo menos cercá-las com outras palavras: tudo menos o jargão do novo espírito do capitalismo, restando evidentemente explicar por que estamos falando a mesma língua ${ }^{3}$. Mas também não estamos ressuscitando o mais emblemático par de categorias herdadas da visão dualista do Antigo Regime de dominação, Civilização e Barbárie. Por que deveria a esquerda arcar com o "fardo do homem branco"? Seríamos os herdeiros da mission civilisatrice do velho imperialismo, como outrora o socialismo oitocentista,

3. Tentei uma explicação num artigo, acho que publicado num boletim da ABONG, "Esquerda e Direita no espelho das ONGs", versão escrita de uma exposição de novembro de 1998 num congresso da referida "entidade da sociedade civil...". Aí mora o perigo. empenhado na realização da verdade progressista do liberalismo, que só seria falso na medida em que enganosamente dava a entender que já era uma realidade? Não deixa de ser uma hipótese - e novamente, piedosamente progressista -, e talvez se explique um pouco por aí a forte tentação de formular à esquerda uma política de civilidade - por que não? -, ocupando o vazio deixado pelo Ocidente capitalista que afinal parece ter se convencido de que essas antigas ambições de levar o comércio e a civilização a todos os cantos do planeta tornou-se puro desperdício de dinheiro: e ei-lo de volta à política de feitorias, sem falar nas expedições punitivas contra a anomia das populações economicamente supérfluas ${ }^{4}$. Ao que parece não foi bem o verniz civilizatório da expansão ocidental que caducou. Há quem associe ao eclipse da alternativa socialista a atual escalada de crueldade, a multiplicação das marcas da maldade; e não se trata apenas da loucura dos pobres mas sobretudo da esquizofrenia dos cidadãos respeitáveis que da noite para o dia transformam-se em hooligans: tudo se passa, vistas as coisas em retrospecto, como se o movimento socialista tivesse funcionado como um filtro "sem o qual a civilização moderna seria totalmente incapaz de existir; privada desse filtro, a economia de mercado sufoca em sua própria imundície"5. Se assim é, seria o caso de acrescentar, entrando agora no capítulo dos pastiches

4. Simplesmente não há mais interesse econômico nas políticas integracionistas. "Largar as ex-colônias, largar os africanos, largar os pobres. Dar um chega-pra-lá nos países e nos cidadãos despreparados para enfrentar a nova ordem econômica mundial" (Luiz Felipe Alencastro. O ocaso dos bacharéis. Novos Estudos, n. 50, 1998, p. 59).

5. Robert Kurz. Os últimos combates. Petrópolis: Vozes, 1997, p. 145, comentando observações do sociólogo Alexander Schultz e do ensaísta HansMagnus Enzensberger. 
objetivos que caracterizam a farsa ideológica dos novos tempos, que tal filtro estaria então sendo descaradamente reciclado a título de suplemento moral da estupidez progressista do economicamente correto. À revelia, é claro, do engajamento antibarbárie dos ativistas sociais - artistas incluídos, cada vez mais arrastados pelos moinhos de vento das "guerras culturais" -, que no entanto vão assim mesmo encorpando os argumentos a favor do novo espírito do capitalismo depois do seu triunfo, do qual os requintes civilizatórios destilados pela prática cotidiana do doux commerce são a joia da coroa, para escarmento da massa sobrante fora dos muros.

Naturalmente ninguém ignora, nem pretende, sobretudo se Freud tiver razão, como parece que tem, caluniar abstratamente o policiamento das pulsões - mas daí a responder, por exemplo, com "tolerância zero" ao retorno do reprimido conforme se intensifica o mal-estar desse outono da civilização do ocidente, nem mesmo Nelson Rodrigues, por sinal um fino adepto do cafajestismo na civilização brasileira, comemorando hoje 500 anos de proezas. Deve ser até em função desse discernimento elementar que os autores do Manifesto se concentraram de preferência na barbárie oficial, só que nos termos mesmos desta última, a requalificação artístico-cultural da urbanidade sitiada, o que nos devolve à encrenca ideológica de partida. Uma complicação tanto maior porquanto os papéis foram invertidos: somos nós a sociedade incivil, somos nós que cuspimos no chão da festa de aniversário... deles, que por seu turno encarnam a boa sociedade civil. É bom lembrar que essa famigerada sociedade civil, antes de virar "parceira" de qualquer coisa, já foi um conceito respeitável, referido à arena da luta pela hegemonia numa sociedade antagônica. Vitimado pela mesma implosão dos significados originários que está nos interessando (retrocesso é reforma, direito é privilégio, barbárie é civilização, etc.), tornou-se um sinônimo reciclado para os negócios desinteressados do Terceiro Setor. Se andamos assim com as cabeças trocadas, não seria mau uma primeira providência, como sugerido, começar trocando o título do Manifesto para "Contra a Barbárie em nome da Arte". Numa palavra, contra a barbárie dos civilizados - que por aqui estrearam reinventando a escravidão, e o tráfico negreiro talvez como forma superior do doux commerce, como já foi dito, veículo civilizador responsável pela transformação das paixões em algo construtivo. Tomada essa providência inicial, posso assegurar que o documento tomaria uma feição clássica. Os Antigos, que sabiam do que falavam, pois afinal foram eles que inventaram o termo, na sua obsessão pela vida ativa, consideravam bárbaros os povos que não por acaso se distinguiam por não terem Estado e sobretudo - quem sabe por isso mesmo - pela desmedida do prazer estético indiscriminado, algo como o nosso "tudo cultural" de hoje, ou a afetação de refinamento oriental a que se entregam os intermediários culturais da nova burguesia compradora de estatais.

Vem de muito longe, portanto, o entrelaçamento de inclinações bárbaras e sensibilidade apurada pelo cultivo da alma. Até aí nada de mais; nos seus momentos de abandono, qualquer esteta wagneriano sabe disso. A novidade é que agora, depois da revanche triunfal dos donos do dinheiro, ficou estabelecido que só o capitalismo civiliza. Está aí a capital do novo imperialismo que não nos deixa mentir. O difícil porém é distinguir no decantado retorno da civilidade em Nova York o que se deve ao doce convívio reavivado pela prosperidade dos happy few planetários (em todo caso não é bem isso que se vê no filme póstumo 
de Kubrick, até segunda ordem um artista de olhos bem abertos), e o que pode ser atribuído com alguma certeza à política de tolerância zero do novo Estado Penal americano, não só na rua como no mundo do trabalho ${ }^{6}$. Mais especificamente, tudo se passa como se apenas o cosmopolitismo superlativamente encarnado na alta finança carregasse consigo as sementes da nova civilidade global.

Pensando bem, as coisas não mudaram muito. Não é de hoje que os grandes predadores no comando do aparato de dominação, nos momentos de auge da riqueza financeirizada, privatizam o inteiro circuito das artes. É bem verdade que não se poderia falar a rigor de um domínio público a ser confiscado no tempo da alienação financeira das encalacradas cidades-estado italianas nas mãos das mais poderosas casas bancárias do século dezesseis, quando pela primeira vez ocorreu o fenômeno ${ }^{7}$, salvo é claro - mas é justamente isso que importa em tais conjunturas - no que tange ao vertiginoso endividamento público. Acontece que o Estado, sangrado pelos donos do dinheiro, de que carece para a gestão da política territorial e portanto da guerra, só poderia garantir a renda dos seus credores na medida mesma em que se especializava na extração compulsória de recursos das populações, e em troca de

6. A respeito das relações entre civilidade penal e políticas de requalificação urbana numa cidade tipicamente "revanchista" como Nova York, ver o estudo de Otília Arantes, "Uma estratégia fatal: a cultura nas novas gestões urbanas", do qual extraí meu comentário, in Otília Arantes, Carlos Vainer, Ermínia Maricato, A cidade do pensamento único. Petrópolis: Vozes, no prelo. Para não dizer que se trata de um preconceito "bárbaro", a propósito da Tolerância Zero (que em Brasília, DF, se tornou Segurança sem Tolerância: para variar, quando um "civilizado" diz mata, há sempre um brasileiro para dizer esfola), ver o artigo de Jorge da Silva, coronel da reserva da Polícia Militar do RJ, OESP, 23.05.2000, p. C6.

7. Assinalado por Giovanni Arrighi, in O longo século XX. Rio de Janeiro: Contraponto, 1996. uma proteção que só poderia oferecer enquanto monopolizasse o uso da violência. Qualquer semelhança com o crime organizado não é mera coincidência ${ }^{8}$. Voltando ao esbulho de hoje, dá para perceber que o cenário continua o mesmo. Na origem da atual expropriação privatista da cultura sob o regime do alto patrocínio, nos deparamos invariavelmente com todo tipo de manobras visando à obtenção de um exclusivo qualquer, como é próprio da configuração rentista da riqueza, da propriedade da terra ao atual cercamento de marcas, patentes e audiências. Em última instância, o que promete qualquer operação de alta patronagem cultural? Nada mais (e precisa?) do que a exclusividade do acesso a um ambiente tão seguro quanto o de um clube (que apresenta o inconveniente de marketing de figurar apenas no colunismo social, não por acaso invadido hoje por culturetes de todos os bordos) onde elites empresariais e políticas se encontram, fazem as devidas conexões (sociedade em rede demanda conectividade; novamente, qualquer semelhança com o crime organizado, etc.), numa palavra, se reconhecem e confirmam mutuamente como tais, mas sobretudo comparecem sob a luz da mídia aureoladas pelos seus respectivos agentes culturais: "criadores", fomentadores, curadores, mecenas de carteirinha, jornalistas culturais, promoters, editores "criativos", administradores oficiais e extraoficiais, etc., etc. Até mesmo as megafilas nas atuais exposições arrasa-quarteirão dão claramente a entender que tal monumento, recoberto pela grife exclusiva dos patrocinadores, está no momento generosamente abrindo suas portas à visitação pública.

8. A observação é de Charles Tilly, Coerção, capital e estados europeus. São Paulo: Edusp, 1995. 
Não estou dizendo nada que os signatários do Manifesto não saibam, e além do mais por experiência direta. Apenas repassei o atual cenário de conquista e rapina para melhor realçar o acinte. Aqui a novidade. Ao contrário do que imagina o prezado companheiro da "Fundação Belo Autônomo" em sua campanha pela Educação Estética da Humanidade (infelizmente o projeto de Schiller não pegou por falta de cooperação da parte de uma sociedade civil mais proativa), a economia continua no comando, e como sempre apresentando a conta a quem não tem mais como pagar. Com a diferença de que nos tempos do decoro vitoriano não se podia levantar impunemente o véu que encobria a origem misteriosa da riqueza e do bom tom, um gesto bárbaro de extremo mau gosto. Ibsen que o diga, sobretudo porque hoje estaria arrombando uma porta aberta. O colapso da ordem liberal-burguesa, cuja derrocada se estendeu pelos trinta anos que separam as duas guerras mundiais, aliás uma só, pontuada por campos de extermínio e holocausto nuclear, por assim dizer democratizou o cinismo. Durante três décadas o fiasco histórico da fraseologia liberal funcionou como uma espécie de crítica ideológica espontânea, trazendo para a superfície a realidade subterrânea da exploração, cruamente exposta, em cena aberta, e mesmo descaradamente reivindicada por quem de direito em nome do realismo. A caminho da extinção, não se pode dizer que a espécie desapareceria sem conhecimento de causa. O arranjo do pós-guerra apenas recobriu a fratura exposta com razões técnicas, sendo o Estado Social uma arena de conflito distributivo permanente: a anestesia durou enquanto houve crescimento e a mercadoria continuava sendo entregue onde havia consumidores solventes, mas não se poderia dizer que se voltara ao regime anterior de encobrimento e subli- mações próprio das grandes formações simbólicas. Num certo sentido as crises ficaram mais claras: não é muito difícil se convencer de que doutrinas políticas, sistemas filosóficos, códigos jurídicos e assemelhados não podiam mais ofuscar a verdade enunciada pela fórmula trinitária do Apocalipse da civilização capitalista, Auschwitz, Gulag, Hiroshima, a simbiose entre forças produtivas, servidão e extinção. Mais claras, porém mais impenetráveis, à medida que se aprofundava a degradação ideológica rumo ao grau zero da existência simbólica, pois a performance econômica (para nós, desenvolvimentismo e industrialização periférica) como fonte exclusiva de legitimação do sistema quando muito destilava um "sentido" muito raso para um regime absurdo de acumulação interminável, uma justificação meramente pragmática para efeitos de autoconservação mediante redistribuição (forçosamente desigual) do produto e da proteção social. Cristalizou-se assim uma nova intransparência, diversa da anterior pois desprovida de qualquer alegação "transcendente". A antiga ideologia por assim dizer tornou-se "imanente", e por isso mesmo oca, sem outro conteúdo do que a própria realidade - segundo uma interpretação clássica daquela época -, mera afirmação da sociedade realmente existente, sans phrase ${ }^{9}$, simplesmente reconfirmada por sua reduplicação pela indústria da consciência, dita também cultural, que não é "ideologia" de coisa nenhuma pois não diz nada, funcionando como uma psicanálise às avessas, como sustenta aquele mesmo diagnóstico da finada Era do Crescimento. Esse mundo de alienação administrada veio

9. No que se deve reconhecer o embrião da "animação cultural sem frase" de hoje, de que trata um capítulo do livro Urbanismo em fim de linha (São Paulo: Edusp, 1999), de Otília Arantes. 
abaixo a partir dos anos 70, como se sabe. E com ele desabou também a força persuasiva dos feitos estilizados do desenvolvimento que, deixando de ser mundial, provou ser uma ilusão, a menos que se passe adiante o mito do capitalismo que deu certo num só país, a um tempo mitologia imperial revigorada pela mera força bruta das coisas e disparate cognitivo a respeito de um sistema histórico que já nasceu simultaneamente global e nacional e assim há de morrer. Aprofundada e congelada sem anestesia a descomunal estratificação da economia mundial, era de se prever uma ressurreição apoteótica da exibição cínica de poder e desfrute tal como nunca se tinha visto desde o período do caos sistêmico entre as duas guerras mundiais. Com a diferença para pior (se é que se pode falar assim) que o grande bate-boca entre as classes em luta ${ }^{10}$ naquela antevéspera do horror próximo, parece estar hibernando hoje enquanto as novas oligarquias imperiais continuam falando não sozinhas, mas entre si, além do mais com as contribuições da esquerda (ética? cultural? civilista?) para o jargão único.

Deu-se então o escândalo espantoso do nosso tempo. Num momento em que, entregue a si mesmo, voltou a ameaçar a sobrevida da espécie no planeta, o capital vai convencendo a imensa clientela que se acotovela nos guichês de entrada de que só ele civiliza. (Ao que parece tal escárnio objetivo é recorrente: Norbert Elias, não por acaso hoje na moda, principiou inocentemente o seu ciclo de ensaios sobre o processo civilizatório em plena ascensão do Terceiro Reich). Que os bárbaros justamente são os

10. Como Roberto Schwarz caracterizou o confronto das grandes massas corais na Santa Joana de Brecht, no ensaio de apresentação de sua tradução em 1982, depois em Que horas são?, São Paulo: Companhia das Letras, 1987. barrados na festa: porque não são competitivos, são consumidores insolventes, são perigosos (mas estes resolvem a bala a frustração do consumo, à moda do high life), são parasitas do Estado Providência, são intelectuais ressentidos-com-a-nova-complexidade-do-mundo e por isso esbravejam como sérvios, etc. Assim sendo, a motivação econômica das condutas não só pode mas deve ser exposta como fonte legitimadora de racionalidade e agora de civilidade: espera-se de um executivo caçador de cabeças encarregado de uma reengenharia destruidora de empregos que apresente as boas razões da companhia, o que fará de acordo com um roteiro prévio da mais estrita urbanidade, a nova cifra da autenticidade ética nos negócios como nos bons tempos do existencialismo, bastava puxar uma angústia em comum. Não deve ser por outra razão que o cinema americano de hoje vem se especializando numa espécie de sub-realismo em que pequenas "barbaridades" cotidianas são incorporadas desde que acompanhadas de uma confissão a céu aberto, plena de tato e savoir vivre, com o que deixa de chocar, o que conta é o espírito desarmado, a afabilidade que só se encontra nas sociedades que estão dando certo... Pois é, não é isso mesmo o que atesta o casamento legítimo do big business com a alta cultura?

A estetização do poder que só a riqueza confere evidentemente não é de hoje, a bem dizer tem a idade dos rituais de polimento do aparato gestual de dominação, como se sabe, codificados pelas primeiras sociedades de corte, coreografia sob a qual justamente evaporava numa nuvem de mítica beleza a fonte sanguinária de tamanho apuro nos costumes. Em linha evolutiva com essa matriz originária da civilidade, a sociedade imperial de hoje se distingue pelo desocultamento ostensivo do comando incontrastável da economia, só que agora devidamente 
glamourizado pela culturalização do dinheiro. Essa a face contemporânea da barbárie em nome da arte, o horror econômico praticado como uma das belas artes. Restaria saber o que leva suas vítimas e demais candidatos à desgraça econômica a renaturalizar a evidência do artefato fabricado à luz do dia, atribuindo-a a uma causalidade sistêmica insondável e imutável ${ }^{11}$. A voga incongruente da civilidade redentora faria então todo sentido. O realejo do polidamente correto sinalizaria assim o arranjo final para uma convivência de fim de linha, numa sociedade sem alternativas. Não faltou aliás quem se perguntasse, desde o lançamento dessa panaceia redentora, se uma tal reentronização da polidez na categoria das grandes virtudes não queria dizer que se estava precisamente renunciando, à esquerda é claro, àquela suprema falta de educação que consiste em virar de pernas para o ar a ordem estabelecida $^{12}$. Alguns anos depois, constatando a catástrofe

11. É pelo menos seguro que não se trata de um juízo de conhecimento; a admissão de uma fatalidade econômica não é fruto de um raciocínio que redunde numa atribuição intelectual. Christophe Dejours é de opinião que o fenômeno é da ordem dos mecanismos psicológicos de defesa, reforçados no caso pela intensificação do que chama de trabalho atroz. Cf. C. Dejours, A banalização da injustiça social. Rio de Janeiro: FGV, 1999. Deu no Boletim da Sociedade de Cultura Artística "O Belo Autônomo": "a civilizadíssima Amsterdã acaba, neste mês de outubro, como notícia Le Monde de 16.10.98, de aderir à política de tolerância zero. Comportamentos associais serão doravante delitos punidos à altura. A conclusão a que chegou a cidade é que o tecido social esgarçou-se ao ponto de ruptura. A situação em que a cidade decidiu que se encontra (sic, sic) corrobora, infelizmente, a tese que sustentamos aqui no "Belo Autônomo": a destruição da cultura política pode encontrar na situação econômica precária de um país, família ou indivíduo, um fator de agravamento mas não o fator determinante; a cultura política hoje se desmancha em virtude de causas culturais bem mais amplas que requerem, para serem corrigidas, providências de natureza antes cultural do que econômica. É mais do que tempo de colocar a pirâmide marxiana sobre sua própria base: infraestrutural não é a economia, é a cultura. Daí o nosso constante brado programático: tudo pelo cultural!". Elevador de última geração.

12. Régine Dhoquois, prefácio de A polidez. Porto Alegre: LP\&M, 1993. A que representava habituar-se à ideia de que não há mais saídas coletivas para os desastres do nosso tempo, e que a atual epidemia de depressão dificilmente se explicaria se esse quadro de impasse histórico fosse escamoteado, uma psicanalista observou que hoje em dia os sujeitos deprimidos costumam ser de fato muito polidos ${ }^{13}$. Foi-se o tempo em que a rebelião das massas constituía uma ameaça à civilização, em que ainda se podia falar de "uma barbárie positiva", como o fez Walter Benjamin nos anos 30, confiando na tabula rasa da modernidade que anunciava vida para além do capitalismo ${ }^{\mathbf{1 4}}$. Hoje, como estamos vendo $^{15}$, a ameaça vem de cima, das elites em estado de secessão social e desterritorialização nacional, graças ao último refúgio oferecido pela globalização do dinheiro mundial, a moeda do Império ${ }^{16}$.

edição francesa é de 1991. O nosso João da Ega sempre dizia que o desacato é a condição do progresso. É bom não esquecer.

13. Elisabeth Roudinesco. Por que psicanálise? Rio de Janeiro: Zahar, 2000.

14. Cf. Walter Benjamin, Experiência e pobreza. In W. Benjamin. Documentos de cultura, documentos de barbárie. Seleção e apresentação de Willi Bolle. São Paulo: Cultrix/Edusp, 1986.

15. Depois do último ensaio de Chistopher Lasch, bem entendido, A rebelião das elites. Rio de Janeiro: Ediouro, 1995.

16. Nunca é demais lembrar - aliás, na presente circunstância é decisivo - que essa desterritorialização das camadas dominantes nunca é absoluta, nem poderia ser. Não são tão lineares assim as relações entre Capital, Estado e Território. A nova classe de rentiers, somados aos "barões das privatizações" que tomaram o lugar da antiga burguesia nacional - e nacional à revelia, pois se consideravam prisioneiros de um território econômico sem moeda conversível -, ao mesmo tempo em que conseguiram conectar seus interesses nas redes dos investidores externos e das burocracias multilaterais que policiam monetariamente a periferia capitalista (cf. Leda Paulani, Vulnerabilidade ampliada, Jornal de Resenhas, 13.05.2000), estão estruturalmente vinculadas ao Estado nacional que lhes assegura uma renda patrimonial mínima, e não há hipótese de que esta variável independente do capitalismo histórico desapareça, pelo menos nas regiões relevantes: por isso, na boa observação de Fernando Haddad, qualquer vitória eleitoral da esquerda (coisa que nunca 
Um dos pensamentos delicados da nova barbárie "tudo pelo cultural" consiste em propagar a boa nova de que hoje ingressamos numa era de invenção permanente de direitos. A cultura entraria no pacote de última geração. Na verdade, o que de fato vem ocorrendo há duas décadas é um espantoso processo de destituição de direitos. Com a noção moderna de direito, entre tantas outras do antigo repertório iluminista, e entre elas a ideia de civilização, como estamos vendo, deu-se igualmente a mesma rotação no sentido contrário, passando a significar privilégio a ser cassado, pela marcha inelutável das forças produtivas, é claro, afinal agora somos todos materialistas, não é verdade? O desenganado progressismo de antigamente (o de hoje é mais desabusado) via no cidadão um ser em evolução, cuja marcha ascensional aos céus da política principiava pela conquista dos direitos civis e culminava nos direitos sociais, dos quais talvez ainda se lembrem alguns europeus com mais de 60 anos. A mesma visão se aplicava ao Estado, que teria vencido as mesmas etapas de ampliação de seu sistema de garantias individuais e coletivas, "evoluindo" do Estado de Direito ao Estado Social, cujo triste fim se conhece. À acelerada involução de hoje já se deu o nome de desjuridificação, por oposição aos ciclos anteriores de crescente extensão e consolidação de direitos, avançando sobre a terra de ninguém dos nexos sociais colonizados pela forma-mercadoria. Exemplo dessa desjuridificação, o desassalariamento selvagem em curso no mundo, que reverte a força de trabalho, que não é uma mercadoria qualquer, de

ocorreu na história do Brasil, no que concerne o único poder que conta) sempre lhes aparecerá como uma ameaça de expropriação (cf. Fernando Haddad, Patrimonialismo e democracia, FSP, 18.8.99.). Isso para lembrar que a arena política local continua inteira e que, por incrível que pareça, a nova classe dominante também continua barbarizando por aqui mesmo. fato nem mesmo é uma mercadoria, à condição bárbara de mero artigo de comércio (condenado quando não encontra comprador), o que a anterior relação salarial "juridificada" pelo menos em parte represava. Viu-se que era provisória $^{17}$, e que o capital decididamente não será nunca um animal doméstico. Pois seria então o caso de dizer que o avesso do atual processo de desjuridificação vem a ser a estetização extensiva da riqueza capitalista que se está vendo. E, de fato, um dos traços constitutivos da nova barbárie consiste em trocar direitos por "cultura".

Dessa barganha assustadora se poderia até reconstituir a contabilidade elementar, algo como a economia política da civilidade culturalista. Com efeito, o inchaço "cultural", que vai assimilando imaginação e inteligência ao toma-lá-dá-cá de comércio e patrocínio, tem certamente a ver, como se disse, com o rentismo predominante de hoje. Ocorre, como também já foi lembrado, que tal configuração patrimonial da riqueza não seria o que é sem o tipo de renda mínima que o endividamento exponencial do Estado - e por isso mesmo cada vez mais fiscalista e superavitário - assegura ao capital, por meio, é claro, entre outros instrumentos (como as privatizações financiadas com fundos públicos), da asfixia do que ainda sobrevive do Estado Social ${ }^{18}$. Ora, o mais espantoso é que sobre os escombros do falecido Estado Providência está se edificando um próspero Estado Penal, para o financiamento do qual o orçamento públi-

17. Nota da digitação: como expressamente prometera Keynes ao Capital na fundamentação de sua proposta de um Welfare State.

18. Segundo Robert Reich, ex-secretário do trabalho na primeira administração Clinton, atualmente sobra dinheiro para o Welfare, o que falta é vontade mesmo, et por cause. Cf. Valor, Fim de Semana, 19.05.2000, p. 11. Trata-se obviamente de um macropopulista, por isso não foi promovido para o segundo mandato. 
co (americano, em primeiro lugar) não parece conhecer qualquer limite. Ainda para efeito de contabilidade é bom lembrar que "tolerância zero" também quer dizer penas exorbitantes para transgressões irrisórias, que obviamente tendem a explodir em tempos de desemprego endêmico e salários desmoralizantes. Quer dizer, aumento igualmente exponencial da população carcerária, e dos negócios correspondentes na nova indústria da prisão, a começar pela privatização das cadeias públicas - outra iniciativa americana pioneira $^{19}$. Já se disse que as prisões funcionam agora como substitutos de sucesso das agonizantes instituições do bem-estar ${ }^{20}$. Ganha-se assim nas duas pontas da corri-

19. Nota da digitação: sem dúvida nenhuma um avanço em relação a Auschwitz e iniciativas conexas do Terceiro Reich, uma vez que lá a exploração do trabalho escravo e a indústria do genocídio precisaram da mediação do Estado, entrando na coluna dos custos. Agora é investimento lucrativo sem intermediários: entre outros ganhos de produtividade, houve simplificação na própria contabilidade. Nota do indigitado: demasia lógico-política da Digitação? Quase nada. Diante da gestão empresarial de homens desprovidos da maioria de seus direitos nas prisões privatizadas, não são poucos os juristas que precisam esfregar bem os olhos para crer no que estão vendo e pressentindo: "numa penitenciária privatizada, em que o preso é convertido em mão-de-obra compulsória, de que modo enquadrar seus deveres, como condenado judicial, com seus direitos trabalhistas, enquanto operário? (...) Qual o interesse dessas firmas, cujas 'fábricas' podem enfrentar problemas de flutuação de mão-de-obra, em ressocializar os presos que se revelarem excelentes trabalhadores em suas linhas de montagem?" (José Eduardo Faria. Prefácio ao livro de Laurindo Dias Minhoto sobre a gestão da violência no capitalismo global, Privatização de presídios e criminalidade. São Paulo: Max Limonad, 2000).

20. Cf. Zygmunt Bauman. Os estranhos da era do consumo: do estado de bem estar à prisão. In $\mathrm{O}$ mal-estar na pós-modernidade. Rio de Janeiro: Zahar, 1998, p. 57. Não tão estranhos assim à esfera do consumo-compulsão: veja-se, no estudo citado de Laurindo Minhoto, como os assim chamados "excluídos" da nova ordem econômica são "incluídos" na condição de "consumidores cativos da indústria da punição”. Nessa mesma linha de generalização do trabalho forçado não entram apenas os working poors, dentro e fora das grades: segundo o principal teórico americano da macdonaldização da sociedade, George Ritzer, não é só nos restaurantes fast food que as pessoas estão começando a pagar pelo privilégio de trabalharem de graça como consumidores - e em fila. Cf. Ritzer, The Mcdonaldization Thesis. London: Sage, 1998, cap. V. da ao corte de custos, desempregando de um lado e encarcerando de outro. Pelas mesmas contas, também se ganha na virada do "social" para o "cultural". Este último - nunca será demais repetir - banalizando e estilizando a devastação da guerra econômica, a cujo motor, como sabemos, seria tão impolido e descortês aludir como outrora era de bom tom escamotear, pelos rituais do decoro, a vulgar existência do próprio corpo, que nem por isso se deixava de exibir e vender. Tudo somado, não se pode negar que é pela mão invisível do novo Estado Penal que também vai se regulando o mercado de amenidades cívico-culturais.

O mundo certamente deve ter saído dos eixos, a ponto de nos empurrar para uma coabitação de parede-meia com o horizonte rebaixado dos vencedores globais e, o que é pior, falando a mesma língua de estereótipos edificantes. Um deles é o passe-partout da Civilização, pouco mais do que uma senha para o grande amálgama da Barbárie, que vai enfiando um pouco de tudo no mesmo balaio colonial, dos degoladores da Mazorca do ditador Rosas aos jagunços de Canudos, das "chacinas" da periferia aos manifestantes que atrapalham o trânsito. Essa a coisa nova e ruim, a vala comum das palavras de sentido trocado. E para as quais devemos ter uma política, a qual por sua vez não é uma questão meramente discursiva, uma batalha semântica pela reconquista da acepção original confiscada - se assim fosse, ricochetearíamos de volta no campo dileto do novo establishment global, o das guerras culturais.

Dito isso, mesmo sem ser baluartista, desconfio que se voltarmos a chamar a Barbárie pelo seu próprio nome, seu par antitético também mudaria de figura. Não estou sim- 
plesmente reafirmando que, no fim das contas, barbárie hoje nada mais é do que o capitalismo triunfante levado ao seu paroxismo. Muito menos repetindo pela enésima vez que a única esperança de que a humanidade coincida alguma vez com seu próprio conceito passa pelo socialismo, seja lá o que isto queira dizer a cada idade histórica específica. Gostaria apenas de sugerir que ainda pode ser útil a evocação de uma antiga verdade "filosófica" do materialismo histórico. Se é fato, como explicado no seu primeiro Manifesto, que a história da humanidade tem sido até agora a história da luta de classes, isto quer dizer, entre outras coisas, que ainda vivemos em plena pré-história. Pois é isso e, assim sendo, a modernidade capitalista nada mais é do que o último capítulo dessa longuíssima crônica de barbaridades. E último capítulo por conta da particularidade do capitalismo, que consiste em trazer consigo pela primeira vez a possibilidade técnica de resolver o problema econômico da escassez. E como não resolve, continuamos na mesma. A rigor a "civilização" ainda não começou, ou então é apenas um outro nome para a barbárie de sempre.

Demasia metafísica? Nem tanto. Em todo caso, empiricamente comprovada pelo fenômeno contemporâneo que acabamos de passar em revista. Pensando bem, o que revela a guerra econômica (e a guerra, no esquema do materialismo, é uma estrutura originária) das grandes marcas mundiais pela imagem superlativamente ostentatória de cultura e patronagem senão a "primitiva" rivalidade pecuniária entre os grandes predadores? O que trai enfim a assimilação atual da cultura à mera autopropaganda, senão a recorrência arcaica do caráter bárbaro da cultura? (Não haveria nenhuma surpresa se acaso um diretor artístico-financeiro - tais funções não se distinguem mais
- resolvesse se apresentar a caráter, com um osso atravessado no nariz, na forma de um eixo curatorial, é claro.) E bárbaro precisamente enquanto mera exibição de poder, rapina e lucro. Recordo que semelhante visão da atualidade bárbara da civilização foi enunciada pela primeira vez no início do século vinte por um sociólogo (sic) à vista dos grandes feitos culturais (na área do fomento, por certo) dos robber barons americanos.

Mas então o que pode a arte para despertar a humanidade do pesadelo em que se debate ao longo de toda a sua pré-história? Enquanto bem cultural, tesouro artístico, reserva ética ou coisa que o valha, absolutamente nada. São troféus de guerra. Porém, enquanto simples forma organizadora da imaginação (para início de conversa), única atividade mental livre do jugo pré-histórico da autoconservação enquanto fim em si mesmo, continua sendo, hoje como sempre, a única chance de acordar. Para a política, é óbvio. Creio que foi isso o que o Manifesto Arte contra a Barbárie quis dizer, e talvez deliberadamente, nos termos mesmos em que a barbárie oficial colocou a questão cultural. 


\section{O nome do sujeito*}

Nunca na vida experimentei um Big Mac. Na minha filosófica inocência nominalista, sempre achei que um hambúrguer é apenas um hambúrguer. E que uma marca é apenas um nome, ou vice-versa. Quanto ao McDonald's, mera cadeia de fast-food. Até começar a ler este $\mathrm{O}$ nome da mar$c a$, os surpreendentes capítulos de Isleide Fontenelle sobre a avassaladora maquina de moer chamada McDonald's. Fiquei então sabendo como se fabrica uma marca e no que consiste seu valor estratégico no capitalismo de imagens. E que assim sendo, o sistema McDonald's não atua no prosaico ramo da restauração rápida, trata-se pelo contrário de um outro negócio, um inédito e bilionário gênero de show-business. No qual se vendem "experiências", no caso, a experiência total prometida por uma "simples" marca. A rigor, vende-se o acesso (como vem dizendo Jeremy Rifkin), acesso a um ritual, no qual se mesclam taylorismo alimentar, ordem unida e romance. Como jamais provei nenhum desses sanduíches de fantasia - na excelente forma de nossa autora - não posso me considerar plenamente iniciado nos mistérios metafísicos de uma Big Mac e seus derivados. Sou portanto um profano.

Resta ver se os crentes, quer dizer os clientes dessa "vivência" altamente produzida, não sabem mesmo o que

* Originalmente, título de um espetáculo teatral encenado pela Cia. do Latão em 1998. Este texto foi publicado como prefácio ao livro de Isleide Fontenelle, O nome da marca, SP, Boitempo, 2002. 
comem, embora o façam assim mesmo, como diria algum nostálgico do materialismo histórico. Mas já não se trata mais do que os indivíduos sabem ou desconhecem, mas do que efetivamente fazem ao entrar numa fila de fast-food. Se Isleide tem razão, agem como se acreditassem na onipotência da marca - que no entanto sabem ser apenas um nome, afinal são indivíduos esclarecidos - quando na verdade são levados a acreditar porque já estão em fila. Como o crente de Pascal, acabam vendo a luz de tanto executar o gesto mecânico de se benzer. São esses novos crentes que interessam Isleide, a seita multinacional dos comedores de Big Mac, e seus respectivos provedores de conteúdo, ditos também "manipuladores simbólicos", agentes inovadores, etc.

Que sujeito é esse, cuja mente é o lugar da marca? Não me atreveria a resumir. Gostaria mesmo assim de encaminhar o leitor para um ou dois traços desse sujeito sem nome, marcado pelo ferro em brasa dessa psicanálise às avessas em que se converteu o marketing enquanto facilitador de uma assustadora passagem ao ato na demanda, algo como a encubadora da violência característica da fantasia do consumo absoluto. Segundo Isleide, o sujeito mcdonaldizado poderia se encontrar em algum ponto um pouco além do drogado e quem sabe mais próximo do depressivo, de qualquer modo, no centro de uma mutação antropológica radical, que por certo não é de hoje. Não se trata de psicologia. Mas da sociedade endemicamente depressiva que o novo capitalismo comportamental está gerando. Não sem paradoxo, como observa Isleide: trata-se de afetar e por em movimento um indivíduo que parece não saber escolher nem mesmo a cor de uma roupa, e no entanto, "o desejo da marca que é, no final das contas, o do próprio capital, é o de criar um estado de depen- dência absoluta do sujeito". Derradeiro desenvolvimento da forma-droga, a marca publicitária funcionaria como um antidepressivo de última geração. Desnecessário lembrar que o argumento de Isleide vai na direção contrária à da nova apologética, que vê na dessubjetivação em curso, o prenúncio de uma sociedade para além do conflito, seja ele psíquico ou social. Por certo eufemismo para um brutal deslocamento da cena política, em que o controle do "acesso" é tudo e o desconectado, um novo proletário, com o perdão da má palavra. A propósito, relembro que franquia também é acesso, e que não há enclosure, ontem como hoje, sem expropriação.

Mas esse é apenas um dos nomes do sujeito. Gosto muito de uma outra observação de Isleide acerca desse eclipse do sujeito em estado de mobilização total ao ingressar na rede imaginária de um fast-food. Na literatura especializada costuma-se arrolar entre os padrões percursores da lanchonete fordista - é bom não esquecer que ela tem a idade industrial e ideológica do automóvel -, as técnicas de alimentação e fornecimento de rações para as tropas americanas em guerra na Europa. (Robert Kurz acrescentaria que o mesmo princípio da linha de montagem já poderia ser observado nas trincheiras da Primeira Guerra, lembrando a propósito como o potencial mecânico de agressão da indústria automobilística foi aos poucos se militarizando, convertendo-se à sua verdade de origem, a destruição em massa.) Seja qual for o fundo de verdade daquela explicação, o fato é que levou a nossa autora a uma observação preciosa acerca de algo que hoje nos parece a coisa mais natural do mundo, fazer fila para comer num restaurante fast-food: "até a inovação efetuada pelos dois irmãos McDonald, Richard e Maurice, no drive-in, em 1948, a existência da fila para adquirir comido só parecia 
estar presente em guerras, prisões ou situações de privação que levasse alguém a conseguir comida através de atos de caridade".

Pois é. Num momento (setembro de 2001) em que o McWorld (na expressão consagrada por Benjamin Barber) está em pé de guerra e o novo poder imperial prepara-se para enquadrar o mundo num estado de sítio permanente (uma outra profecia de Robert Kurz), convenhamos que tal poder de enfileirar as pessoas, e pô-las para trabalhar de graça para a empresa, é de meter medo. Noutra passagem, Isleide recorda que "o mínimo eu" de Cristopher Lasch é justamente a expressão de uma "individualidade sitiada".

Esses homens e mulheres em fila - sabe-se lá no rumo de que catástrofe - são portanto crentes, como já sabemos. Slavoj Zizek, uma das fontes diletas de Isleide, diria que são fetichistas na prática, pois "sua" crença lhes é totalmente externa, não reside nalguma falsa consciência (relíquia da finada Era Liberal), mas se encontra incorporada nos rituais que se cumprem efetivamente no mundo das mercadorias glamourizadas pelas grifes. Como na roda tibetana das orações, as marcas rezam por eles. Podem assim se dar ao luxo de engolir os tais sanduíches de fantasia sabendo muito bem que comandos idiotas como "You deserve a break today" não enchem a barriga de ninguém. E no entanto, tal crença no nome da marca parece sustentar a fantasia que regula o funcionamento libidinal da realidade social - segundo Isleide e seus bons autores. O cartunista que redesenhou as torres gêmeas do World Trade Center encimadas por um luminoso "Just do it", algo deve ter intuído do poder pulsional exercido pelo branding global, sem falar na apresentação surrealista do atentado terrorista como resultado de uma interpretação literal da palavra de ordem da Nike.
A esta altura não seria demais acrescentar que meio século atrás Adorno de certo modo não deixara de anunciar tal desfecho: quando a ideologia já não é mais um grande envoltório discursivo, mas a própria imagem ameaçadora do mundo, converte-se em terror tão logo realidade e propaganda formam um só bloco, acenando para o contragolpe cúmplice do terror contrário. Neste sentido - mas só nesse sentido, o que já é uma enormidade -, tudo se passa como se o skyline de Manhattan desde sempre pedisse dinamite, como no poema de Drummond: sua implosão latente estaria anunciada no simples fato de que o exibicionismo arquitetônico funcionaria ali como "mídia-real", na verdade uma espécie de autoafirmação acachapante do poder social enquanto tal, sem maiores mediações, como quem diz "é isso aí", e não há alternativa. Pelo menos era assim que Adorno entendia esse estágio terminal em que a realidade funcionaria como publicidade de si mesma, como é justamente o caso do McWorld estudado por Isleide, e o seu tremendo paradoxo: se é verdade que os homens se adaptam à mentira desse mundo autista do faz-de-conta, não é menos verdade que enxergam através do seu manto. Com efeito, nada mais óbvio e transparente que as relações de poder nesse funny capitalismo das marcas.

Isleide dá a entender que o desfecho cínico e violento, próprio do desfecho narcísico não é uma fatalidade. No capítulo que ficou devendo, mas certamente irá escrever, sem dúvida algo terá a dizer sobre os novos "sujeitos” que há uma década pelo menos romperam o círculo mágico da fantasmagoria e andam dizendo com todas as letras: No $\log$ ! 


\section{PARTE IV}

\section{ZERO À ESQUERDA: UMA COLEÇÃO DA} HORA

CONVERSA COM UM FILÓSOFO ZERO À ESQUERDA

\section{“Zero à esquerda": uma coleção da hora*}

Lançada no final do ano de 1997 pela Editora Vozes, a Coleção Zero à Esquerda, como esperado, despertou grande atenção em inúmeros setores. Principalmente por ter coincidido com um dos momentos agudos da crise financeira ainda em andamento e trazer títulos que a examinam de diversos ângulos. Por isso a revista Cultura Vozes chamou o coordenador da coleção para uma conversa sobre esses acontecimentos.

Para começo de conversa, achamos bom explicar por que esse nome para a coleção. Para variar, já apareceram mal entendidos, como o de que "zero à esquerda" não conta e por isso esse nome é muito pessimista. Nem é preciso repetir todos os argumentos contrários, você também já ouviu.

Se de fato quem é zero à esquerda "não conta", convenhamos que o título é no mínimo realista. A esta altura do campeonato - e por campeonato entenda-se a modernidade capitalista em seu grau destrutivo máximo -, quem não é um mero zero à esquerda? Kafka sabia muito disso, mas não é preciso ir tão longe. Mesmo quem continua multiplicando zeros à direita, não dei-

* Publicado na revista Cultura Vozes, n.3, ano 92, 1998. 
xa de ser uma bolha tão fictícia (e mortífera) quanto o capital-dinheiro que lhe engorda a conta bancária. Com uma pequena diferença, é claro. Os zeros à direita se caracterizam principalmente por apostas no cassino global com as fichas dos zero à esquerda, a saber, emprego, salário, saúde, etc. Neste momento, a população da Coréia não está justamente fazendo na própria pele a experiência de que não passa de um imenso zero à esquerda? Trinta anos de "crescimento" (uma geração) para nada vezes nada, zerados de uma penada. Mais uma parcela da humanidade que deixou de ser rentável, tornando-se redundante como um zero à esquerda. Nas contas do capital, cada zero à esquerda representa um corte de custo à direita. Nas nossas contas, cada zero à esquerda, um leitor. Como se trata por definição de um sujeito monetário sem dinheiro (afinal não conta nada), imagino que uma coleção de zeros à esquerda não poderia ter chegado aonde chegou em tão pouco tempo se a boa nova ruim de ser um zero à esquerda não tivesse algum efeito milagroso - só podem estar comprando por procuração. A ser assim, veja que a óbvia autoironia do título funciona mesmo quando tomada ao pé da letra, pondo a imaginação de cada um a funcionar na direção oposta, o que propriamente se chama pensar. Quase um título otimista, então - se é verdade que o simples fato de aceitá-lo e dar-lhe corda já significa que a esquerda está se reapresentando com um novo conhecimento de causa. A rigor um título achado, como todos os trocadilhos - tratava-se na ocasião de encontrar o equivalente brasileiro do italiano Sinistra punto zero, um livro meio desigual desses balanços correntes da esquerda ocidental depois da Queda.
Para não perder o costume, vamos atalhar um pouquinho e depois você retoma. É que, falando em Queda, seria interessante passar por aquele ponto (punto zero?) que poderia ser mesmo um bom ponto de partida, a saber, como se entende - e a coleção como um todo tem essa referência - o chamado fim do "sistema soviético" que serviu de álibi para tanta capitulação...

Não é tanto um atalho, porque, apesar do duplo sentido, creio que "zero à esquerda" é uma fórmula inequívoca na recusa tanto do baluartismo (não confundir com a obstinação de quem não entrega fácil a rapadura, tampouco com o "não mudo de Opinião" no day after do revertério de 64) quanto do chamado pragmatismo das "revisões" dos que se adaptam ao novo curso. Só quem pensa abstratamente se refere a teorias críticas, ou a processos sociais, em termos de certo ou errado, bom ou ruim, quando na verdade se trata de pô-los em perspectiva histórica, e verificar qual ciclo se cumpriu e não qual o "sistema" (correto) se impôs sobre outros. Basta observar que o fim dos trinta anos dourados do pós-guerra não arruinou apenas a economia soviética de comando, as periferias desenvolvimentistas e as sociedades europeias de compromisso, mas lançou na mesma crise as economias ditas vencedoras, empenhadas hoje em rifar contingentes cada vez maiores de suas populações que o buraco de agulha do mercado tornou supérfluas. Mesmo assim a contagiante estupidez dos vencedores disseminou a miragem de uma normalidade capitalista ao alcance da mão, reforçada pelo espetacular desastre soviético enquanto "modelo" perdedor. Diante da tentação de zerar o próprio juízo e se ajustar por reflexo condicionado, digamos que o propósito de um zero à esquerda consista justamente em revelar ponto por 
ponto a calamidade que vem a ser a sociedade a que todos aspiram sem exceção - a começar pela esquerda de resultados, que ainda sonha com uma regulação civilizatória do capital, do tipo redução da jornada de trabalho sem (?) perda salarial e na louvável intenção de estancar a crise da sociedade do trabalho e contribuir (por que não?) para incrementar a competitividade das respectivas economias nacionais ou regionais, conforme o voto não menos piedoso do par de vasos Bourdieu/Touraine, por exemplo, desde, é claro, que consintam neste arranjo os acumuladores de dinheiro e poder. Quando os eleitores do bom e honesto Jospin descobrirem que o cofre está vazio, teremos uma outra rodada de ajustes e custos zerados, desta vez com a mão direita mesmo. Falei em esquerda de resultados para não caluniar em vão a finada "velha esquerda" - comunistas, social-democratas europeus e desenvolvimentistas periféricos, queimados todos pela explosão do sol fordista - mas pensando por tabela no tipo ideal do zero à esquerda, para começar uma esquerda que não fale apenas daquilo de que se fala na televisão, deixando-se pelo contrário pautar por um novo sentimento histórico de oposição. Cá entre nós, coisa inédita em países em eterna "construção" como o Brasil, onde poeta de vanguarda lança manifesto de apreço e louvor por serviços prestados à cultura nacional.

E pelo visto, parece que tem mais zero à esquerda na praça do que se pensou no começo. Afinal foram três edições em quatro semanas e tudo indica que vem mais por aí...

Quanto a isso, sinceramente, não queríamos ter acertado tanto, não é muito agradável ter razão numa hora destas, pois sabemos bem quem vai pagar a conta.
Sobre a coleção como tal: ela tem uma concepção muito diferente do que se tem visto...

Duas ou três palavras antes de passar aos inesperados laços de família envolvendo os cinco (ou quatro e meio) livros de estreia da coleção.

Dá licença de protestar? Não é porque você é o autor do que chama de "meio" livro que temos o direito de deixar os leitores sem saber que essa também é uma proposta da coleção: a cada "pacote", lançar pelo menos um liuro de bolso (de qualquer gênero, pode ser sátira como é o Diccionario, pode ser ensaio, ficção, poesia, etc.) que dialogue com a própria coleção. Embora voto vencido, eu preferiria que o tempero humorístico fosse uma constante desses livrinhos... Registrado o protesto, você ia falar dos laços de família.

Como a crise - que alguns autores chamam até de crise de decomposição - não é normal, uma coleção concebida em função dela não poderia ser normal, uma boa iniciativa editorial entre outras. Nada contra, até porque também é este o caso. No entanto, o tamanho e a natureza da crise pedem um passo adiante. Note, para começo de conversa, que o lançamento na forma de um pacote comentado (embora nem sempre resenhado como tal) lembra um pouco o que deveria ser norma no caso de uma revista de intervenção político-cultural que se preze, por definição animada por um coletivo empenhado em tornar por assim dizer narrável o limite histórico no qual estamos batendo e para tanto encomendando "matéria" aos quatro cantos do ainda pequeno mundo que não se "ajustou". Alinhados um ao lado do outro, esses títulos de agora não parecem 
compor o sumário de uma revista? E veja que ninguém precisava concordar com ninguém - aliás convivem ali no mínimo dois ou três cenários da crise contemporânea - para que um certo ar de família se imponha como uma evidência ainda por definir. Se não é uma coleção "cultural" anódina - bisonhamente a favor ou contra a tal de "globalização", tanto faz, deixemos as ponderações acerca dos dois lados do fenômeno para os acacianos do governo e da oposição - tampouco é de doutrina e no entanto me parece que não lhe falta caráter, que pode inclusive se encarnar em roteiros de responsabilidade propositiva (vá lá) de cada um. Afinal creio que neste fim de linha continuamos todos interessados em alternativas emancipatórias, não obstante, ou por isso mesmo, não nos encontrarmos na antevéspera de nenhum limiar ascendente - para falar à maneira "progressista" de antigamente. Imagine então o sumário de cada fornada como indicativo da articulação ensaística de tópicos que não costumam andar juntos, seja porque é da natureza do processo separá-los e contribuir para o ofuscamento geral, seja pela decorrente miopia própria da cultura dos especialistas. Definitivamente, compartimentação por currículo universitário ou estereótipo político de assessor de partido não é conosco, mas tratar cada questão nos seus próprios termos, o que implica tratá-la obrigatoriamente nos termos das demais. É verdade que à primeira vista - tanto à vista da Esquerda do título quanto dos livros iniciais, pensando inclusive no pacote de abril, com perdão do trocadilho involuntário - parece uma coleção de economia política, e é assim que os livros estão sendo classificados nas livrarias. Esperamos desfazer logo essa primeira impressão, que não é falsa sem ser verdadeira. É fato que principiamos pelo entrelaçamento de Poder e Dinheiro no coração dessa verda- deira ruptura de época (para pior) que estamos padecendo na condição de perdedores globais, tirante o habitual deslumbramento do Ocupante de turno. Mas não ficaremos por aí. Tudo interessa e tem a ver com tudo (salvo, é claro, o trivial variado universitário, que não tem nada a ver com nada), pois uma das características da crise atual é sua condição de revelação do presente a ele mesmo e a luz que lança sobre o passado recente e a história da modernização capitalista. Em princípio nada ficará de fora, da economia política da globalização à poesia dos sans culottes de subúrbio, passando pelo cinema e pela antropologia da desindustrialização americana, pelo colapso das metrópoles brasileiras e pela cultura do contra segundo os grandes refratários (Marcuse, Guy Debord, Pasolini, Raymond Williams, Alexander Kluge, etc.) - e por aí afora. Em suma, já dá para perceber que somos daquela turma mal-encarada que não costuma separar estética de política, pela simples razão de levar a arte tão a sério a ponto de confiar no depoimento histórico infalível da forma artística, mesmo quando malogra, ou sobretudo nestes casos.

Ótimo. Já que você bateu nesse item obrigatório do credo frankfurtiano, vamos retomar (e de preferência avançar sobre) a nossa velha e boa pendenga em relação ao marxismo ocidental e sua versão brasileira da qual somos, não importa o grau de adesão, tributários assumidos.

Não dei este exemplo por acaso, se o plano era puxar o eventual fio vermelho que atravessa estes livros de estreia - e os próximos, está claro. Pois bem, avançando um pouco o sinal e pensando em voz alta, diria por ora mais ou menos o seguinte, adaptando para os meus propósitos es- 
quemas provenientes da tradição do marxismo ocidental, incluindo seu capítulo brasileiro, sobretudo no registro muito original em que o interpretou Roberto Schwarz, pesquisando as razões que levaram ao topo da mais abrangente coalizão conservadora da história republicana um dos principais teóricos daquela mesma tradição local. Digamos de início que a presente coleção nada mais é (também) do que uma modesta tentativa de contribuir para que esse tropeço monumental (para dizer o menos) não se repita mais. Pois bem: pode-se dizer que o nascimento do assim chamado marxismo ocidental (por oposição ao soviético, recente, e o da Segunda Internacional, que vinha da tradição do século passado) nos anos vinte e trinta se deve a um diagnóstico de época em que a antevisão da ruptura revolucionária próxima (e era efetivamente o que se via entre as duas Guerras Mundiais) fazia corpo com uma crítica radical da sociedade de mercado total, em que a prática emancipatória em curso era impulsionada pela análise tão abrangente quanto analítica e normativa da alienação moderna em todas as suas formas, da contradição em processo na acumulação aos microprocessos de racionalização repressiva. Deixo de lado as vicissitudes de um longo interregno, sendo a principal delas o consenso keynesiano que parecia ter congelado até mesmo a hipótese de crise sistêmica em sociedades antagônicas porém complexas. Deu-se então uma longa amputação - em nome é claro da prevalência da estática sobre a dinâmica na reprodução no capitalismo avançado - da dimensão que se poderia denominar de emancipação negativa pela luta de classes e sua expressão política. Enfim, o núcleo propriamente estratégico da teoria crítica cuja carga negativa refluiu então para a vida intelectual confinada ao ensaio de crítica cultural - à exceção de Marcuse na vira- da de 68, sem entrar por enquanto nas tropelias do engajamento francês antes e depois daquela reviravolta. Isto quanto à cultura marxista no ocidente europeu. Repare ainda como a atrofia da imaginação política estratégica impediu por exemplo os frankfurtianos, que se fecharam então em copas (como ainda reparava outro dia um colega Zero à Esquerda, aliás, também uma praga, mora), de dar o passo adiante requerido pelo acerto do seu propalado pessimismo no que concernia o futuro da "velha esquerda": pelo menos desde a guerra já sabiam que o horror stalinista era a expressão trágica da modernização soviética; quanto ao Welfarestate, viam nele o triunfo da mais acabada e administrada alienação social; terceiro-mundismo então, industrializado ou não, nem pensar. Quando os três colapsos convergiram, a direita que patrocinara o desenvolvimentismo na periferia, o Estado Social na Europa, além de conviver em condomínio com a União Soviética, colheu os frutos ideológicos desse naufrágio (para não falar dos materiais, é claro) enquanto essa esquerda de que estamos falando (nem "velha" nem "new") acabou assumindo uma orfandade que não lhe competia. Deu-se o contrário na periferia - para encurtar, pois o descolamento daquelas duas vertentes entrelaçadas no marxismo ocidental originário, a saber a Crítica da Economia Política levada adiante nos termos de uma Crítica da Cultura e esta última centrada no processo de socialização pelo valor, foi bem mais nuançada do que eu poderia dar a entender neste momento. Como o nosso capitalismo-escravista não cabia em nenhuma bibliografia, nem sem disparate no etapismo do marxismo ortodoxo soviético, foi necessário recomeçar do zero até se dar uma visão realmente original das singularidades de nossa dinâmica periférica. Acresce que ao tomar distância, por razões ób- 
vias, da perspectiva proletária clássica, esta variante heterodoxa ao mesmo tempo em que ganhava em clarividência teórica perdia em senso histórico de oposição (salvo no combate modernizante obrigatório contra o emperramento oligárquico) na exata medida em que por outro lado ia incorporando o ânimo construtivo alimentado pelo imperativo civilizatório entalado na passagem da Colônia a Nação. Na verdade esta assimilação não chegou a se completar, por “n” razões que não posso esmiuçar numa conversa tão breve. O fato é que a crítica da cultura na acepção materialista do termo, entendamos crítica imanente em sua negatividade sem resto, foi relegada, a ponto de se perder por completo a noção de que era preciso emendar na cultura ainda viva da nossa tradição modernista em polêmica com a civilização capitalista hegemônica. Quanto à outra metade, esta, em contrapartida, floresceu numa direção inusitada - e novamente sou obrigado a comprimir na mesma gaveta marxistas ocidentais, cepalinos, neokeynesianos de esquerda, futuros dependentistas de todos os matizes, isebianos e ortodoxos dissidentes como Caio Prado Jr., etc. - , que poderíamos batizar de "marxismo legal", à maneira dos russos do início do século procurando redenção para o despotismo oriental nas virtualidades civilizatórias do capitalismo. Assim, o que minguou até a extinção em Frankfurt (deixo por enquanto Paris, Turim e Londres de lado para não enredar ainda mais nossa trama Zero à Esquerda), sobrou por aqui, a saber cálculo estratégico dos passos a serem dados, no caso, no rumo da superação do subdesenvolvimento, como se dizia então, que implicava desde negociação até ruptura com o "imperialismo" (outro termo que voltará sob nova conceituação, seja dito de passagem, et pour cause), de sorte que nos seus próceres mais bem pro- porcionados tal marxismo acabou gerando estadistas engajados ou militantes-homens de estado, híbridos de uma peculiaríssima dialética do engajamento intelectual no Brasil, em que o compromisso social do homem culto, legitimado por irrepreensível lógica progressista, vem consolidar, com as melhores intenções do mundo, como já foi dito, o bloco das autoridades e competências modernas, no topo do país organizado. Deu no que deu. Ficamos devendo o grande passo totalizante interrompido em 64 e que as grandes análises subsequentes do novo ciclo de modernização conservadora prometiam. Não que a dimensão estratégica da nossa cultura de esquerda tenha desaparecido por inteiro, pelo contrário, foi revelando aos poucos seu estreito raio de manobra nacional, exigindo cada vez menos uma nova Crítica da Economia Política e decantando cada vez mais o horizonte adaptativo das políticas econômicas. Muito do caráter decepcionante da nossa Abertura vem menos de sua óbvia feição conservadora do que da constatação retrospectiva de que o melhor de nosso marxismo dito ocidental não era mais do que um marxismo industrializante nos velhos moldes evolucionistas do mais burguês dos séculos. Daí uma outra transição sem traumas de uma cultura oposicionista para uma cultura de governo - data não por acaso das vitórias eleitorais regionais de 82 o então pouco notado porém cada vez mais consternador silêncio das esquerdas. Novamente, deu no que deu. Inclusive uma espantosa aberração. Enuncio sem poder me explicar por extenso. Um dos nossos autores - aliás, o Zero à Esquerda por excelência, um outsider de cuja independência não há paralelo na história intelectual brasileira recente (e já sabemos por quê), sobretudo independência em relação ao establishment de esquerda (admito que mais fácil na Alemanha que no Bra- 
sil - estou me referindo a Robert Kurz obviamente), a quem se pode creditar algo como uma reversão do quadro frankfurtiano da não-participação sem no entanto se tornar um empreendedor político - o amigo Kurz então, considera encerrado o ciclo histórico do que denomina marxismo do movimento operário, a seu ver imanente ao processo de afirmação do capitalismo, o qual por sua vez teria chegado ao limite absoluto da mercantilização total da sociedade, responsável pela implosão simultânea do sistema de assalariamento do trabalho abstrato e da regulação política da ordem econômica estruturada pelo valor de troca, porém capítulo conclusivo de abertura de um outro, o até aqui desconsiderado (salvo exatamente pelo Lukács de História e Consciência de Classe e os frankfurtianos que lhe seguiram os passos, excetuado ele próprio, aliás) Marx da crítica do fetichismo socialmente devastador próprio de um sistema histórico absurdo em que se acumula capital para se acumular mais capital. Ora, sem forçar muito a nota, creio que dá para dizer que foi justamente o complemento "proprietário" ou "senhorial" desse marxismo do movimento operário em sua variante periférica que foi promovido à condição de "operador" (serviços ideológicos incluídos, inclusive a alegação muito oportuna de estar substituindo uma classe dominante historicamente inepta) — daí também o antagonismo convergente entre grandes proprietários da força de trabalho e donos do poder e do dinheiro no bloco das autoridades modernas, todos mais ou menos de acordo em apresentar a demência capitalista como um sistema que existe para gerar... empregos. Mas, por favor, lembre-se de que estou lhe falando de uma aberração à luz de um esquema que você não precisa tomar ao pé da letra, nem eu. Aliás, muito cá entre nós, não posso esconder que ao aproximar assim autores à primeira vista tão distantes me vejo animado também pelo propósito, não diria piedoso, de que aprendam uns com os outros - isto é, a rigor nós leitores, em cuja imaginação eles talvez se aproximem - relativizando os respectivos cenários da crise sistêmica em que estávamos mergulhados fazia tempo sem ter muita noção - outra aspiração zero à esquerda: deixar de fazer oposição sem Teoria, apenas requentando marmita (as boas coisas de sempre) ou clamando aos céus por justiça (nada contra, até porque de vez em quando faz bem). Assim, não desespero de ver o amigo Kurz - na esperança de que se recupere do eclipse do pensamento estratégico de cunho emancipatório: afinal mesmo a exigência de "crédito" apresentada a um "fundo público" para a reprodução da vida fora do mercado e longe do Estado esbarrará no poder de veto dos "investidores" e outros encilhadores - repassando sua tese sobre a implosão do paradigma "sociológico" da luta de classes pelo crivo proposto pelo amigo Arrighi aí ao lado, a saber, a dialética entre poder social e penúria maciça da classe operária desigualmente distribuída entre o núcleo orgânico e a periferia do capitalismo histórico, e o futuro que ainda lhe reserva o desenlace da atual crise de hegemonia mundial, se é verdade, como sugere ainda o mesmo Arrighi, que a transformação da ciência em força produtiva - por motivo de corte de custo no ciclo descendente e não em virtude de uma revolução microeletrônica em geral, se lhe fosse permitido corrigir o colega de coleção - se por um lado solapa o poder social da classe operária tal como a configurou o apogeu fordista, por outro lado, relançando o antagonismo histórico num outro patamar, torna mais forte também a tendência do capital em sujeitar essa força de trabalho gerencial e científica ao seu domínio, tornando a 
bem dizer fatal sua proletarização, de sorte que a transferência de poder social das mãos do velho proletariado industrial pode muito bem ser o prelúdio para um futuro crescimento de seu tamanho e poder. Deixo a réplica do Kurz por conta da imaginação do leitor: aliás antecipo que o próprio Arrighi seria o primeiro a concordar que o dito paradigma da luta de classes não detém mais por inteiro a virtualidade da solução e que nada garante que a forma predominante de organização proletária do século XXI não esteja sendo prefigurada pelas milícias sérvias e croatas - com o que, emendaria o amigo Kurz, a sociedade produtora de mercadoria alcançaria o seu desfecho lógico, a economia de pilhagem, com o Estado voltando a ser o que era na origem, um bando armado. Mas se é assim diria um leitor bem zero à esquerda - se uma era se encerra reproduzindo em escala planetária a violência sem frase da acumulação primitiva que abriu o caminho da modernização, então o próprio Kurz se veria na interessante contingência de tomar ele mesmo a iniciativa de restringir seu argumento acerca da redundância irreversível do trabalho vivo por motivo da transformação da ciência em força produtiva na origem de uma Terceira Revolução Industrial, quem sabe até reconhecendo nesta determinação tecnológica em última instância um subproduto do assim chamado por ele mesmo progressismo marxista do movimento operário (e já vimos a contrafação dessa figura aqui no nosso quintal, expressão inesperada da secular ansiedade da elite brasileira se vendo sempre atrasada de uma revolução industrial, de Joaquim Nabuco aos ocupantes de hoje): assim, se o resultado já estava no prólogo, será preciso admitir - à contracorrente da miragem um tanto inocente do progresso técnico entravado por relações sociais de produção retardatárias - que as famosas forças produtivas que vinham se desenvolvendo e empurrando a história para a frente, de revolução em revolução, na verdade desde a origem nunca deixaram de ser literalmente destrutivas. Ora, o mais divertido (por assim dizer) neste enredo é que este acréscimo não se deve à imaginação do nosso leitor zero à esquerda, mas sim ao nosso amigo Kurz ele mesmo, o qual vem há algum tempo puxando por um outro fio, o das origens destrutivas do capitalismo enquanto permanente economia de guerra, quando a organização militar da sociedade se autonomizou, pois com a arma de fogo em cena, os beligerantes não podiam mais se equipar por si próprios, precisando para tanto de um poder social centralizado provedor de armas e, no mesmo passo, da mediação do dinheiro, acoplando de vez economia da morte e economia monetária. Tanto é assim que os soldados - que passaram a matar por um soldo, isto é, somente por dinheiro, fazendo abstração de qualquer conteúdo, ideologia ou inimigo histórico - foram na verdade os primeiros assalariados modernos, e os senhores da guerra, os primeiros empresários schumpeterianos, sendo que estes últimos, para conduzir os negócios da guerra (que se tornavam também cada vez mais abstratos), dependiam dos grandes poupadores e financiadores da guerra: em torno dessa permanente carência financeira da economia de guerra cristalizou-se o poder estatal centralizado e seu sistema de impostos e endividamento público. Até aqui, Kurz sobre a origem destrutiva do capitalismo. Mas a esta altura o nosso leitor zero à esquerda já terá notado (conforme aliás os altos desígnios que presidiram a concepção original da coleção Zero à Esquerda) que, ao puxar por este ponto o nosso fio (se é que podemos falar assim), estará trazendo para o seu campo a parte superior do iceberg de Giovanni Arrighi, a competição interestatal 
por capital circulante na origem e expansão do capitalismo histórico, o outro domicílio oculto em que na luta pelos benefícios da acumulação se encontram o dono do dinheiro e o dono do poder político onde, na bela fórmula de Braudel, circulam os grandes predadores e vigora a lei da selva. Como era de se esperar de uma ordem social fetichista, arremataria a seu gosto o amigo Kurz, que acabamos de ver circulando com a desenvoltura do ensaísta entre o andar superior em que negociam os grandes fetichistas (acumuladores de capital e acumuladores de poder concorrente entre seus pares para continuar acumulando indefinidamente as duas faces da mesma abstração destrutiva) e o andar inferior, o domicílio oculto da produção segundo Marx, onde o dono do dinheiro e o dono da força de trabalho se encontram - aqui, na figura militar do protoassalariado e o povo miúdo sangrado pelo aparato fiscal da nova economia da morte. Resta o andar intermédio - estudado pelo Arrighi no livro que estamos publicando na coleção, que não existe em inglês pela simples razão de ter sido montado aqui no Brasil pelo seu prefaciador, imodestamente um outro resultado zero à esquerda. Sempre no esquema braudeliano adaptado pelo Arrighi, o andar intermédio da economia de mercado e sua estratificação originária, cujas leis de ferro (pois a Coréia não quebrou?) tendem, sem descontinuar, a polarizar os domicílios ocultos da produção em locais centrais e periféricos. Acho que nesse ponto outra vez nosso leitor zero à esquerda vislumbrará outro encaixe, e não pensará duas vezes (espero) antes de pular na brecha. Nosso tipo ideal notaria em primeiro lugar que a fórmula de Kurz para a crise, entendida como uma verdadeira ruptura de época (e não uma crise do regime de acumulação à espera de uma nova definição que virá embora tarde) - "colapso da mo- dernização" - , não se presta sem uma ligeira suspeita de contrassenso à descrição das turbulências nos países centrais. Não sabemos bem o que pensar por exemplo de um colapso da modernização americana ou francesa, ainda que o Kurz especifique que desta vez a crise está avançando da periferia para o centro: noutras palavras, o "colapso" se refere basicamente à desconexão do Terceiro Mundo no início dos anos 80 e depois à ruína do sistema soviético, embora potência militar, tudo menos uma região central de acumulação, pelo contrário, nada mais periférico, ou melhor, mais exatamente, semiperiférico, na conceituação que Arrighi tomou de Wallerstein e finalmente definiu de um ponto de vista econômico estrito (por assim dizer "espacializando" e "politizando" as consequências da teoria da inovação capitalista segundo Schumpeter). Sendo assim, os dois "colapsos" se referem precisamente à "modernização" da semiperiferia. Quer dizer: o seu esforço permanente para não decair até a periferia e ascender até o núcleo orgânico que desfruta da riqueza oligárquica do sistema - esse o fosso que não se deixa transpor, pois é próprio de tal riqueza implicar exploração e exclusão. Ora, o que verá então o nosso leitor zero à esquerda no colapso kurziano da modernização senão uma outra comprovação da "ilusão do desenvolvimento", desmontada ponto por ponto por Arrighi ao descrever a crise em que num dado momento histórico entraram as duas estratégias semiperiféricas de "desenvolvimento", a pró-sistêmica adotada pela América Latina (e a seu modo pelo sul da Europa), e a antissistêmica, pela qual se aventurou a União Soviética? A meu ver a superposição desses dois cenários ainda vai dar muito pano pra manga. Repare que não estamos falando de pouca coisa. A primeira estratégia falida (e historicamente recorrente) concerne a nossa constru- 
ção nacional interrompida (para falar como Celso Furtado, e se Arrighi e Kurz têm razão, cada um a seu modo, interrompida para sempre, ou melhor, enquanto durar o capitalismo histórico e sua polarização tríplice irredutível, ou o sistema mundial produtor de mercadorias, enfim as sociedades fetichistas propriamente ditas), enquanto a segunda dá um balanço inapelável nos movimentos antissistêmicos impulsionados pelo projeto autoderrotista de conquista do poder central num sistema hierárquico de estados e acumuladores interligados e concorrentes. Não é pouca coisa. E assim por diante. Se não perdi meu fio, creio que deste sistema de encaixes também acabará resultando nossa modesta contribuição zero à esquerda para cobrir o tal déficit de negatividade na cultura de esquerda, que aliás não é só brasileiro. Mais especificamente: um cimento zero à esquerda para juntar as duas metades da cultura teórica antissistêmica de que estávamos falando a propósito do marxismo ocidental enquanto componente um tanto reticente da tradição crítica brasileira. Estamos emergindo, pelo menos o que restou do bloco dos desajustados, depois de duas décadas enterrados até o pescoço no conjunturalismo adaptativo das políticas econômicas alternativas. Repito pela enésima vez: deu no que deu, e felizmente, por um providencial cochilo oposicionista, ficamos fora, zero à esquerda mesmo. Rejuntadas as duas metades, certamente haverá de engrenar (mas não de zero, é claro) um novo ciclo de tradição crítica brasileira, não por acaso enraizada no lugar geométrico da falsa consciência do capitalismo histórico, a semiperiferia que acaba de perder sua última ilusão. Este o foco de um novo diagnóstico de época como crise. Mas agora, com pleno conhecimento de causa, enquanto crítica civilizacional antissistêmica que só poderá evitar a armadilha sistêmica da imanência se enfim recompuser o processo na sua integridade alimentando a crítica da economia política da "globalização" com a negatividade originária da crítica desfetichizante da cultura.

Para concluir, uma ou duas linhas sobre os brasileiros da coleção. O Diccionario flagra a coreografia dos ajustados locais de várias procedências (dos que já nasceram a favor aos que foram ficando aos poucos) e por isso é tão engraçado; é de rolar de rir e ao mesmo tempo desconcerta um pouco o leitor que não tenha o costume de acompanhar a nossa imprensa com o distanciamento bem-humorado proposto e exercitado pelo autor. Poder e dinheiro reconstitui o mais importante e, se me permitem, histórico debate local sobre os rumos da hegemonia americana neste fim de século, num nível analítico só facultado aos que, como a nossa mestra Maria da Conceição Tavares, não hesitam em nadar contra a corrente e por isso podem afirmar sem medo de erro, e com pleno conhecimento de causa, o contrário do que todos estavam dizendo. Em Os moedeiros falsos José Luiz Fiori explica paciente e didaticamente cada passo (e suas respectivas consequências desastrosas) da estratégia de ajuste escolhida pelos egressos daquilo que já foi aqui identificado como o nosso marxismo ocidental de corte industrializante. (C.V.) 


\section{Conversa com um filósofo zero à esquerda*}

Goethe dividiu a vida de seu personagem Wilhelm Meister em dois romances, Os anos de aprendizado e Os anos de peregrinação. No primeiro, o foco está posto na formação do indivíduo Wilhelm Meister, enquanto o segundo desloca esse foco para os liames desse indivíduo com a sociedade. Seria esse um bom mote para que você nos falasse de sua formação intelectual?

Um bom mote, sem dúvida. Porém pela razão inversa. Convenhamos que se trata de um simpático despropósito comparar o destino de um filho da Baixada Santista aos desdobramentos da vocação teatral de Wilhelm Meister. Aliás estou me lembrando agora de um trecho do comentário do Bento [Prado Jr.] ao "Prefácio a uma filosofia", do [Oswaldo] Porchat, este sim um eminente filho da Baixada. Em 1967 deu em A Tribuna, de Santos, anunciando o doutoramento do Porchat: "Um santista defende Aristóteles". No artigo em questão, o Bento a certa altura comparava o dito "Prefácio" a um Romance de Formação goetheano, chegando ao requinte de comparar o prosaísmo da reconciliação de Wilhelm Meister com o curso do mundo, à reconversão do filósofo santista à realidade de-

* Entrevista publicada em Marcos Nobre e José Márcio Rêgo (orgs.), Conversas com Filósofos brasileiros, SP: 34 letras, 2000. 
pois dos seus Anos de Aprendizado e Viagem, tudo isso sem deixar de ressaltar o paradoxo de uma certa estetização da vida cotidiana da parte do Homem Comum, por definição avesso ao lado noturno da existência. Tanto faz se o Bento estava pensando tudo isso seriamente ou não, possivelmente as duas coisas, filosofando e se divertindo ao mesmo tempo. O fato é que o trecho provoca uma forte sensação de paródia involuntária, e não há nada mais brasileiro do que isso. Embora vivamos num país tomado por uma ansiedade crônica com a sua formação nacional, sempre adiada, interrompida etc., imaginar-se alguém protagonista de um Bildungsroman no Brasil é uma senhora enormidade. No modelo clássico, em Goethe ou Hegel, a rigor só há "formação" no pressuposto de uma espécie de racionalidade superior governando a marcha das coisas, de sorte que a formação se completa pela conversão de uma espécie de loucura subjetiva a essa marcha ascendente do mundo. Ora, no Brasil tal curva formativa deveria ser descendente. Ou, por outra, segundo o metro patriarcal que nos pautava, seria o caso de se falar de uma verdadeira deseducação. Não por acaso, foi isso o que Roberto [Schwarz] viu nos anos de iniciação e viagem de um engendro da escravidão como o nosso Brás Cubas.

Dito isso, o que eu poderia dizer acerca dessa pergunta? Que a minha formação, no sentido frouxo do termo, aconteceu nos anos 60, na Faculdade de Filosofia da USP. A Maria Antônia foi o primeiro contato de fato que tive com vida intelectual organizada e funcionando no país.

Como foi a sua militância na Juventude Universitária Católica [JUC]? E o seu contato com padre Vaz?
Entrei formalmente na JUC em 1962, quando comecei meu curso de Física na Faculdade de Filosofia da USP. Há alguns anos minha família achava que eu andava meio esquisito. A meu favor só tinha o fato de que eu jogava futebol muito bem, na várzea e na praia. Imaginem alguém em Santos, no fim do curso colegial, que não tinha namorada, não queria roubar o carro do pai, estudava o dia inteiro, era o primeiro da classe e andava com umas roupas estranhas. Enfim, colocaram-me em terapia em São Paulo. Isso foi no início de 1959. Eu fui e simpatizei com o terapeuta, Paulo Gaudêncio, que me cooptou da forma mais sutil, como, guardadas as proporções, Alceu Amoroso Lima fez com Oswald de Andrade: bateu-lhe a carteira quando se ajoelhava diante do crucifixo. E ele me levou para a JUC. Eu ia periodicamente a São Paulo para as sessões de terapia e gostava da conversa intelectualizada. Gaudêncio estimulava minhas veleidades culturais. Nas férias de julho de 1959, Paulo Gaudêncio perguntou se eu não queria passar uma temporada em Itanhaém com seu grupo de estudos. Cheguei lá e era um encontro da JUC. Tratando-se de um jovem de dezesseis anos, fragilizado, foi conversão imediata, pois um tipo nessas condições adere a qualquer espírito sagrado que aponte na sua frente. Podia ser o Partido Comunista, ou qualquer outra coisa. No meu caso foi a JUC e a Igreja, num momento em que despontava nela uma ala progressista, forte e não inteiramente mentecapta, num momento especial do país.

Logo depois de entrar na JUC, entrei na Física, politizei-me à esquerda, sem preconceitos contra o marxismo, conheci o Brasil e entrei no movimento estudantil no momento mais esplendoroso da história nacional, antes de 1964. Foi nessa época que conheci padre Vaz. Ao mesmo tempo, eu era abastecido literariamente e encorajado por 
Antonio Candido [de Mello e Souza] a seguir por esse caminho de empenho político. Foi quando descobri que ele não só conhecia como admirava o padre Lebret, fundador do movimento Economia e Humanismo. "Você faz muito bem, Paulinho" - costumava me dizer Antonio Candido - "Você sabe de uma coisa? Eu acho religião detestável, mas tenho muita admiração pela igreja, sobretudo por esses padres de vanguarda que você frequenta".

Frequentei o curso de Física durante um ano, larguei-o, e fui para o Rio de Janeiro, onde fiquei dois anos, para fazer militância política. Eu estava lá no dia do incêndio da UNE. Acompanhei de perto a fundação da AP [Ação Popular] (oficializada num congresso em Salvador em janeiro de 1963). Eu apenas acompanhei a evolução inicial, já que eu não podia entrar pois era dirigente nacional da JUC. A AP foi um fenômeno. Em menor proporção pode ser comparada aos primeiros passos do PT, também com forte impregnação católica de esquerda. Ela incorporava algumas coisas do marxismo, era antistalinista mas fazia frente com o PCB. No prazo de um ano, a AP ganhou todo o movimento estudantil, inclusive as uniões estaduais. De 1962 a 1964 só deu AP, desde a presidência de Aldo Arantes até a de [José] Serra.

Depois que você saiu da direção nacional da JUC, o que você fez?

Saí depois do golpe e passei seis meses na Europa. Voltei e abreviei tudo, ou seja, fui direto para a Filosofia. Quando eu estava na militância estudantil, vinha sempre a São Paulo e de vez em quando me hospedava na casa de Antonio Candido. Ele e Gilda [de Mello e Souza] costumavam me contar histórias do Departamento: "Nosso Departamento é muito bom. Se você está decidido a voltar para a filosofia, vai ser muito bom para você. Há jovens muito interessantes lá". Daí falavam de Bento Prado, Ruy Fausto, Giannotti. Eu estava certo de que voltaria para cá. Com a Maria Antônia, descobri finalmente a vida cultural brasileira real. No Rio, foi uma festa efêmera, embora tenha sido importante enquanto episódio político. Quando cheguei a São Paulo, foi um revelação. Em poucos meses, eu me distanciei do período no Rio, achava aquilo ridículo, vexatório e maluco. Então a referência passou a ser todo o paideuma da Maria Antônia. Foi a grande revolução intelectual da minha vida. Dou muito valor a isso também porque foi nessa época que conheci o Bento, além do mais meu primeiro professor. No primeiro dia de aula fomos tomar chope; voltei para casa às seis da manhã, iniciado numa nova mitologia.

No Rio de Janeiro, eu visitava com frequência padre Vaz em Friburgo, porque ele era o elaborador teórico da AP, tinha lá a sua dialética do reconhecimento das consciências. Os jesuítas tinham uma bela biblioteca, e Vaz sempre me emprestava livros: As investigações, de Husserl, livros de lógica, os Manuscritos do jovem Marx. Ele não tinha preconceito nenhum, dizia: "Leia o jovem Marx, mas leia também Husserl, a fenomenologia e, sobretudo, lógica e matemática". Eu levava os livros para o Rio e ficava lendo essas coisas malucas. Tanto é que quando fiz o vestibular da Maria Antônia, eu já tinha lido as Meditações cartesianas, e dei uma de pedante. Bento estava me examinando no oral e perguntou o que eu já havia lido. Respondi que conhecia a fenomenologia. E ele perguntou o que eu já tinha lido de Husserl. Disse-lhe que havia lido as Meditações cartesianas. Então ele inquiriu: "Você pode fazer um resumo das Meditações?". "É muito complexo”, disse a ele [risos]. 
Quando estudante de filosofia na rua Maria Antonia, você travou contato com o "Seminário Marx"?

Não. Naquele momento, ninguém falava mais do "Seminário Marx”. Giannotti dava as suas aulas e não se referia ao "Seminário". E eu não tinha conversa de bar com ele. Nossa conversa era estritamente de aluno com professor. A conversa de bar, onde tudo acontecia, era com o Bento. O Ruy não frequentava bar, e não falaria do "Seminário". Então, o que eu sabia vinha do Bento e um pouco do Roberto, pois, naquele momento, eu me dava mais com o Bento do que com o Roberto. E o Bento só contava o folclore do "Seminário". Eu não tinha por que me interessar, pesquisar o "Seminário Marx", pois, além de tudo, estava fazendo o meu curso direitinho.

Foi em Paris que eu descobri o mundo, o Brasil e a Faculdade. Roberto começou a ordenar esse folclore. Antonio Candido tinha acabado de publicar a Dialética da malandragem, e para Roberto foi um "abre-te, Sésamo". Boa parte do Machado [de Assis] do Roberto saiu da compreensão daquele ensaio. Ele me explicou então como é que toda a obra de Antonio Candido estava organizada. Foi nesse momento que Roberto começou a me contar a história do grupo que lia O capital. Eu não fazia a menor ideia, não sabia como funcionava, que havia um caráter interdisciplinar, qual era o objetivo etc. Roberto foi o primeiro a assinalar o caráter crucial da intervenção de Giannotti. Só muito mais tarde é que tratei de sistematizar essa história.

O "Seminário Marx" era um grupo de amigos de esquerda insatisfeitos com o fato de não haver um curso regular e bem feito sobre Marx. Os sociólogos, historiadores, economistas, que faziam parte do grupo, precisavam de um Marx bem dado para escreverem suas teses. Eles dispunham do programa "economia e sociedade", delineado por Florestan, para estudar "classes sociais", "relações de raça” etc., mas achavam-se desarmados, e resolveram estudar Marx. Muitos deles já o conheciam, porque tinham sido militantes. Mas eles não queriam o Marx da Segunda e da Terceira Internacional, queriam o dos textos. Eles não tinham a menor noção da existência do Althusser, e, no entanto, estavam fazendo a mesma coisa que Althusser começava a fazer na Europa. Então era para entender bem Marx, fazer direito as suas teses e explicar o Brasil.

Como se tratava de Marx, como havia dialética e filosofia, e como se imaginava que era preciso ler Hegel para ler O capital, foi necessário chamar os filósofos. Giannotti, que era amigo das pessoas desse grupo (de Fernando Henrique [Cardoso], de Octávio Ianni, de Fernando Novais), chegou dizendo: "para entender a dialética, vamos começar lendo o texto". Essa foi a revolução! O artigo fundamental, que Giannotti redigiu em nome do grupo, "Notas metodológicas sobre O capital" é um dos grandes textos (do grupo e) de Giannotti. Este e o ensaio "Contra Althusser". Ele ainda não tinha assimilado inteiramente História e consciência de classe, de Lukács, não conhecia os frankfurtianos, e não sei se ele já conhecia Althusser (na época da sua tese, seguramente já conhecia). Giannotti fez isso sozinho: juntou [Martial] Guéroult com a vigilância dos economistas e sociólogos para ler o texto de Marx. E mostrou que ali havia uma coisa chamada abstração; abstração real, um processo diferente de formação de conceito, ou seja, mostrou a dialética funcionando.

Giannotti saiu dali e o que fez? Ele se considerava ainda como alguém que estava juntando fenomenologia e lógica, antipsicologismo e dialética. Não era marxismo. 
Para fazer uma ontologia do ser social ele escreveu o primeiro livro dele, Origens da dialética do trabalho. Já o Bento era sartreano. O mundo sartreano tornara-se senso comum para ele: era socialista, existencialista e gostava de literatura. A partir de 1964, da noite para o dia, Sartre fica na gaveta e ele passa para Rousseau. Quer dizer: o "Seminário Marx", para o Departamento de Filosofia, não significou absolutamente nada. O fato de Giannotti ter visto o pessoal discutindo O capital, Fernando Novais elaborar a sua tese sobre a crise do Antigo Regime colonial, Fernando Henrique começar a estudar a relação entre capitalismo e escravidão, não adiantou nada. Porque ele era filósofo.

O que eu quero dizer é o seguinte: o "Seminário Marx" não teve nenhuma repercussão no Departamento de Filosofia, tanto é que eu fiz o curso sem saber de nada.

Como foi a sua volta da França? No capítulo "Ajuste intelectual”, do livro O Fio da Meada, você diz o seguinte: "Inexistente nos anos 60, as relações entre a filosofia universitária com a indústria da consciência em nosso país datam da década seguinte". Na sua volta da França, você já teve essa impressão?

Não, seria incorreto dizer que tive. Na verdade, neste trecho, eu estava pensando principalmente na coleção Os Pensadores, que começou a ser editada quando eu ainda estava na França. O [José Américo Motta] Pessanha fez a coleção e arregimentou praticamente todo o Departamento de Filosofia da USP para traduzir, compilar e prefaciar os fascículos. Esta foi a primeira manifestação pública da hegemonia da filosofia uspiana. Curiosamente, Pessanha era discípulo dileto e grande admirador de Álvaro Vieira
Pinto, que ele considerava um professor extraordinário. Ele veio para São Paulo e recorreu aos uspianos, ou seja, foi o reconhecimento tácito que tinha se formado ali algo de importante. Pessanha recorreu a esses professores para realizar um empreendimento industrial, porém como garantia do bom nível dos fascículos, das traduções, das antologias e assim por diante. Imagine o salto que foi dado com essa coleção, principalmente em relação ao acesso a traduções de qualidade, bem feitas e bem anotadas. O Rubinho [Rubens Rodrigues Torres Filho] "inventou" um Nietzsche no Brasil, pela primeira vez ao alcance de um público que não conhecia mais língua estrangeira, e ao alcance da massa de estudantes que os militares estavam colocando nas universidades. E o que se iria fazer com essa massa? Filosofia em grego não dava. Foi preciso colocar Platão e Aristóteles na Abril. E isto foi uma revolução.

Nessa época, o Departamento estava saindo do gueto através de Marilena [Chaui] e Giannotti. Giannotti tinha a vantagem de ter ajudado a montar o CEBRAP [Centro Brasileiro de Análise e Planejamento], não era mais professor da USP e estava se tornando uma espécie de líder metodológico da oposição. Já Marilena teve desde o início uma enorme repercussão pública, bem maior que a de Giannotti. Marilena por assim dizer desfrutava de um dos handcaps favoráveis da nossa formação francesa. Ela acompanhou a transformação da filosofia francesa na época do estruturalismo. Essa transformação começou com Sartre e Merleau-Ponty, que não eram propriamente scholars, como Goldschmidt e companhia. Eram também intelectuais públicos, dirigiam uma revista, Temps Modernes, e falavam de vários assuntos. Um filósofo francês depois daquela transformação era alguém do qual se esperava que falasse de cinema, de pintura, de psicanálise, 
e que além do mais havia sido politizado pela resistência à ocupação nazista e discutia com o marxismo. Além disso, Sartre e Merleau-Ponty foram os primeiros filósofos a largar a referência epistemológica exclusiva. Com isso, a filosofia francesa, que não era a nossa, aumentou o leque de seus assuntos nos quais ela podia intervir com grande repercussão, dada a característica cultural da França desde o Antigo Regime. Em São Paulo, estávamos de costas para esses assuntos. Nós os considerávamos de baixo nível, achávamos que eram apelação literária e jornalística. Para nós, os filósofos eram os professores de filosofia, eram os epistemólogos, como [Gilles-Gaston] Granger, e os historiadores, como [Victor] Goldschmidt e Guéroult. A ponto de Giannotti chegar ao absurdo de dizer: "Goldschmidt é um filósofo mais rigoroso do que Sartre, que não passa de um mau jornalista". No entanto, se o Giannotti não tivesse dito isso, se nós fôssemos sartreanos desde criancinha, não haveria filosofia no Brasil hoje, haveria apenas "Sartres" razoáveis como Bento, que tinha talento, e uma montanha de cretinos imitando Sartre, enquanto ele estivesse na berlinda. Quando ele saísse de moda, não restaria mais nada. Então as modas na França iam e vinham, mas o básico, que era justamente a filosofia escolar francesa, ficava.

A partir do início dos anos 70, Marilena encerrou sua vida, digamos, escolar com o doutoramento defendido, e saiu para a vida intelectual adulta. Pois seu bilhete de ingresso foi justamente aquele cardápio de especialidades francesas. Já vimos do que se compunha: os dois eixos da filosofia universitária francesa - história da filosofia e epistemologia à francesa, quer dizer, Guéroult, Goldschmidt e Granger - reorientados recentemente por uma espécie de segunda transformação da filosofia francesa, o estruturalismo. Com os tópicos deste último - da linguística às ciências humanas, passando pela psicanálise e a nova história -, Marilena já se familiarizara de vez, desde o seu mestrado sobre Merleau-Ponty, o primeiro dos clássicos a entender a novidade de um Lévi-Strauss para os assuntos filosóficos tradicionais. Pois bem, Marilena não só dominava esse repertório franco-uspiano, como se impunha pelo talento com que sabia tirar proveito da técnica retórica da dissertação francesa, uma das especialidades da casa. Quando voltou da Europa com o seu Espinosa pronto na mala, pôs imediatamente em circulação essa nova rotina francesa, o resultado foi explosivo. Com a vida política bloqueada pela ditadura, a vida cultural de oposição foi se recompondo a conta-gotas, primeiro na forma de grupos de seminários mais ou menos privados e discretíssimos - de profissionais liberais à procura de cultura geral, a universitários interessados em se atualizar, e a boa nova naquele momento era o circo francês das ciências humanas - , depois em conferências públicas isoladas, até desaguar nos grandes comícios da SBPC [Sociedade Brasileira para o Progresso da Ciência]. Naturalmente todo mundo convocava Marilena, que, por sua vez, não se sentia no direito de recusar - psicanalistas, sociólogos, historiadores, linguistas etc. Quisesse ou não, porque, afinal, era assim que as coisas funcionavam na França, e aqui, além do mais, tomavam uma inequívoca feição oposicionista. Marilena, à medida que sua ascendência e audiência subiam aos céus, ia, assim, confirmando o estereótipo imemorial e, depois, mera superstição acadêmica, de que cabia ao "filósofo" a última palavra sobre todas as questões relevantes. Mas não era isso mesmo o que estava acontecendo? Com muita disposição e coragem, aliás: o que confirmava outra dimensão mítica do 
personagem, a filosofia como resistência à tirania. Com isso o prestígio daquela coisa morna e meio cinzenta que era o Departamento de Filosofia cresceu exponencialmente. Seria injusto se não acrescentasse imediatamente que a nossa cotação em bolsa também explodira graças ao trabalho do Giannotti junto ao alto clero reunido no CEBRAP, onde também, como nos tempos do "Seminário Marx", questões de método e fundamentação de Deus e sua época eram com ele mesmo, por ser filósofo e estar seguindo a mesma trilha francesa centrada nas ciências humanas e, como Marilena, igualmente na contramão, como exigia o marxismo transcendental que professávamos, e sua irradiação se intensificava conforme se expandia a influência política do CEBRAP, que a partir das eleições de 1974 passara a assessorar o MDB.

Não sei se extrapolo continuando mais um pouco com o fenômeno Marilena Chaui?

\section{Absolutamente.}

Pois então, em meados dos anos 70, uma especialista em Espinosa, de formação uspiana e, portanto, francesa, tornara-se um intelectual público, e, logo, logo, tanto um polo de atração para a mídia como uma referência para a esquerda cultural que estava recomeçando a se pôr em movimento. Ou melhor, artigo de fé para uma das metades em que o Partido Intelectual a partir daquele momento se dividiu, para sempre - aliás, muito, muito antes da guinada à direita da tucanagem (o último revestimento daquela outra metade, com a qual, aliás, sempre me identifiquei e nunca reneguei até o ponto de não retorno de 1994). No campo filosófico que nos interessa, na outra metade (aliás, hemisfério superior) brilhava a estrela do
Giannotti. Mas com a ajuda providencial da Ditadura, continuaríamos todos juntos, como numa família, primos pobres e primos ricos. É óbvio que com a fundação do PT a coisa começou a azedar até desandar de vez. (Hoje não sei mais, desgarrei-me faz tempo, mas, pelo que ouço, pelo menos a família filosófica reagrupou-se em torno de seus maiorais e respectivos clãs.) Seja como for, acho que não se pode perder de vista aquela bifurcação do nosso campinho intelectual paulistano, que, de metamorfose em metamorfose e transfusões de parte a parte, continua vigorando até hoje, alimentando, nos mesmos termos, os anátemas recíprocos, que remontam àquele primeiro estranhamento mútuo entre "atrasados" e "modernos" na inteligência de oposição. Hoje nossas classificações totêmicas distinguem entre "bárbaros" e "civilizados", "nacionalistas" e "cosmopolitas" etc. Por exemplo, foi essa divisão que pesou quando mal inaugurada a Nova República principiou a autofagia gerencialista da Universidade, no campo adverso à suposta inércia corporativa da "outra" esquerda, que se autocondenava por não contar em suas fileiras figuras do primeiro time, salvo, é claro, Marilena, que, no entanto, era e não era vista como tal. Aqui a encrenca, pois ela era inequivocamente uma scholar (hoje o maior currículo da Faculdade, como se diz), porém, com fama (arduamente conquistada) de "populista", inclusive quando desancava o famigerado "nacional-popular". Outro marco: Marilena presente e atuante na fundação do CEDEC [Centro de Estudos de Cultura Contemporânea] em meados dos 70, que entendia se contrapor ao CEBRAP concentrando-se no acompanhamento dos novos movimentos sociais e que por isso mesmo achava que a sua ideia de democracia não era a mesma que o star system do CEBRAP brandia contra o autoritarismo. 
E novamente reencontramos Marilena na linha de frente do debate que afinal reinventou a ideia de democracia no âmbito da esquerda brasileira. Acho que interessa recapitular como, outra mostra do funcionamento a um tempo descarrilado e produtivo da cultura filosófica no Brasil. Quando voltei em 1973, encontrei nossa amiga em plena leitura do Maquiavel de [Claude] Lefort, que era um amigo da casa, pois andara pelo Departamento pelos idos de cinquenta em curtíssima temporada. Mas o interesse de Marilena - que, àquela altura, já beirava o entusiasmo vinha é claro pelo lado Merleau-Ponty, que numa nota de rodapé célebre anunciara a futura obra do discípulo como uma revolução em matéria de filosofia política. Pois foi esta última que Marilena (outra vez no exercício de suas funções filosóficas de fundamentação) começou a explicar (e rendeu-lhe uma apostila quilométrica) aos seus colegas da política e da sociologia - e justamente os serviços da filosofia franco-uspiana eram de fato requeridos, pois até a distinção lacaniana entre simbólico e imaginário entrava no esquema de Lefort, que aliás recorria de modo meio esopiano a Maquiavel para investir contra o sistema soviético. Não deu outra: nascia ali a moldura filosófica de que carecia a noção de democracia perseguida pelos novos "atores" (Touraine, quem diria...) dos movimentos sociais nascentes - coisa de que sequer suspeitava a obsessão anticomunista de Lefort. Quanto a Marilena, descobrira afinal o que fazer com seu Espinosa - possível herança althusseriana da fixação dos marxistas franceses com Espinosa: entroncá-lo na tradição democrática que remontava a Maquiavel. Enquanto do outro lado, o dos primos ricos - no qual eu fazia modesta figuração - , democracia (por enquanto filosofia, Giannotti só chegaria ao tema anos depois) às vezes era apenas sinônimo de antiautoritarismo, às vezes uma demonstração indireta de que o aprofundamento da modernização econômica, mesmo nos marcos inelutáveis da dependência, podia dispensar a Ditadura afinal o ramo rico da família ainda era francamente materialista, e portanto democracia era firula liberal.

Mas não foi apenas nesse front que a nossa ex-rainha do baixo clero saiu na frente. Também foi pioneira na reconversão da curiosidade filosófica profissional para o assunto brasileiro. Tópico aberto e encerrado pelo próprio Cruz Costa, que gostava muito de depreciar o que ele mesmo fazia, sabendo que para a jovem guarda uspiana filosofar sobre o Brasil era um completo despropósito. Acho que de fato o dossiê foi reaberto pela tese do Caio Navarro de Toledo sobre o ISEB, não sei ao certo, mas não se trata de disputa da primazia. O fato é que naquele mesmo ano de 1973 me deparei com Marilena lendo as obras completas de Plínio Salgado, na boa intenção de fazer uma "Crítica da razão autoritária", nem mais nem menos, na pessoa do prócer verdeamarelista. A novidade é claro não estava no assunto, a resistência à Ditadura desencadeara uma enxurrada de estudos sobre o pensamento autoritário brasileiro. Tampouco o que parecia arrevesado no projeto não se devia à falta de nobreza do objeto, pois não há nada de tão raso em nossa matéria local de que não se possa desentranhar tema para reflexão de alcance geral, mas à notável discrepância dos gêneros. Ou por outra, a incongruência resultava de uma certa incompreensão do que estaria em jogo - ou então, para ser mais exato, da compreensão corrente da experiência cultural brasileira, cuja distância em relação ao padrão europeu de vida intelectual socialmente coerente seria mais de grau do que também de natureza. Como não é bem assim, um Plínio Salgado literal era promessa de confusão. Aqui a bifur- 
cação do Partido Intelectual muda de sinal, se o termo de comparação for o anterior a propósito da querela em torno da questão democrática, quando dava para pressentir a deriva "construtiva" dos primos ricos e o alto preço intelectual a pagar pela longa marcha através das instituições que se iniciaria em 1982, com as primeiras administrações estaduais conquistadas pela esquerda. É que se deu o seguinte disparate histórico: a esquerda viva que estava tomando corpo naquele momento, e da qual nossa amiga era uma das madrinhas incontestáveis e que culminaria nesse acontecimento notável que foi a criação pela própria classe de um partido socialista dos trabalhadores, essa mesma esquerda, pela sua ala intelectual mais atuante e influente, nascia desligada, de caso pensado ou não - quanto a Marilena, por certo de caso pensado - , para não dizer ignorando, o melhor da tradição crítica brasileira, como aliás já fora o caso, com a única exceção de Caio Prado Jr., da linhagem comunista, à qual se contrapunha frontalmente aliás a nova esquerda. Hoje dita do tempo das chaminés pelos novos ricos que justamente herdaram e malbarataram aquela mesma herança crítica brasileira de que estou falando. Esse desencontro histórico ainda não foi devidamente avaliado. De minha parte acho que o Roberto [Schwarz] já deu um primeiro e enorme passo observando no artigo sobre o "Seminário Marx" que até mesmo (ou sobretudo) a ala dos primos ricos acabou entregando a rapadura justamente por um "déficit de negatividade" tal que só se explica - inclusive ou antes de mais nada o desastroso marxismo industrializante deles - por não terem sabido se deixar impregnar pelo ímpeto oposicionista da crítica cultural e ensaística de Machado ao Modernismo, impulso propriamente de confronto sem resto com o mundo do capital. Pois de maneira ainda mais dramática - porque não era para acontecer — foi isso que ocorreu com aquela estreia no esforço secular de reversão da tenuidade da experiência brasileira. Não adianta lembrar - ou melhor adianta sim, sentimos mais o drama que Antonio Candido, Sérgio Buarque de Holanda, Mário Pedrosa etc. assinaram a ata de fundação do Partido dos Trabalhadores, por maior que fossem a convicção e o empenho militante, eram vida e obra paralelas. Desencontro abençoado por nossa a miga Marilena, na condição inquestionável de mentora filosófica (última ratio inapelável) da então novíssima esquerda, consagrando o divórcio com o melhor da interpretação do Brasil, não obstante lançado pela mesma época na vala comum da assim chamada “ideologia da cultura brasileira”. Não que esta última não fosse ideológica da cabeça aos pés, o problema novamente era o que sempre deu a pensar a crítica digamos imanente desse mesmo material duvidoso. Mas voltemos às reinações de Marilena, e veja-se se não dá para sentir o drama: é que por incrível que pareça, ela estava na direção certa, e trabalhando sozinha. O que ainda é mais notável em todo esse episódio, é que por conta própria - e vindo de onde veio, de um meio impermeável a esse tipo de questão, a filosofia franco-uspiana - ela percorreu toda a ensaística brasileira de interpretação das idiossincrasias nacionais, em princípio para entender o surto integralista, e se deu conta de que se tratava de um infindável catálogo de ítens faltando no estoque: não tínhamos burguesia ou a nossa não era como as outras; muito menos classes subalternas modernas e autônomas; a classe média era gelatinosa; a sociedade civil, amorfa; a luta de classes, inoperante; o Estado, hipertrofiado; as ideologias, de segunda mão; o capitalismo enfim, era ora tardio, ora diferente. Em suma, o que não faltava era desvio, não éramos o que deveríamos 
ser, e o que éramos era o que nos separava daquilo com o qual não nos conformávamos. Numa palavra, pensando com seus botões, Marilena atinara com a dialética mesma da experiência social brasileira, a rigor com a matéria bruta das incongruências que tal "dialética" sistematizaria de mil e uma maneiras. Simplesmente avançaria o sinal, concluindo mudando de mão: a tradição crítica brasileira, nela incluído o diagnóstico a que me referi, nada mais fizera do que engolir o clichê conservador do Brasil errado e portanto a ser atualizado segundo o padrão das modernizações conservadoras de praxe. Rifado portanto o inventário das diferenças, não nos faltava nada, tudo por aqui estava no seu devido lugar. Como não há história do Mesmo, apagavam-se todas as diferenças da "história nacional": da passagem da Colônia à Nação até o teatro de sombras que teria sido a famigerada Revolução de 30, e por aí afora. Como sobra talento em nossa personagem, não houve falha humana, mas técnica: culpa da filosofia.

E como você avalia a experiência da revista Teoria e Prática?

Quando ela apareceu em 1967, eu era aluno de Ruy Fausto. Eu era um aluno aplicado que morava na fronteira da "Boca do Lixo", sem telefone, televisão nem pensar, e com o dinheiro curto. Estudava em tempo integral, o meu único contato com o mundo real era através do Bento... Vejam só, voltei para a Maria Antônia, larguei a militância política estudantil e resolvi me tornar um super "chato-boy". Risquei todo o meu passado político espiritualista, enquanto Marx passava a ser apenas uma referência epistemológica, que interessava para a lógica e para a ontologia. Isso, via Giannotti. Via Bento, era um Marx mais exótico e interessante, era o Marx de Sartre e Merleau-Ponty. O que realmente interessava era uma boa tese, logicamente consistente, sobre a dialética de Marx. De minha parte, não havia nenhum vínculo social com absolutamente nada. Estávamos de costas para o país, embora fôssemos, do ponto de vista teórico, politicamente avançados. Podia-se ser especialista em $\mathrm{O}$ capital, conhecer toda a história do bolchevismo - como Ruy conhecia -, mas apenas como preâmbulo ou pretexto para uma boa tese de filosofia. Quando eu estava no último ano da Faculdade, apareceu a Teoria e Prática, em 1967.

Foi quando me aproximei mais do Ruy Fausto, que sem o saber se encarregou da minha reeducação política. Ele me fez ler Trotsky, a biografia de Isaac Deutscher, sem falar no folclore do segundo "Seminário Marx", do qual uma parte foi fazer a Teoria e Prática. Foi aí que as coisas começaram a se juntar, quando a Faculdade se radicalizou e os estudantes começaram a passar para a clandestinidade, preparando a entrada na luta armada.

Ora, a minha perspectiva se inverteu: o farol passou a ser a Teoria e Prática, essa era a grande revista e eu tinha de estudar desesperadamente para acompanhar aquilo, porque era ali que as coisas iriam acontecer. Bento continuava a ser a minha reserva literária e filosofante, mas Ruy passou a ser a minha referência política, tanto é que, em determinado momento, eu comecei seriamente a me considerar um trotskista imaginário. E o Ruy me sabatinava, dizendo: "Você está indo bem, já conhece Bordiga".

Você foi para a França em 1969. Defendeu seu doutoramento sobre Hegel em 1973, que veio a ser publicado no Brasil em 1981 e que acaba de ser publicado na França. Como você avalia esse seu doutoramento hoje? 
Já ouvi muitos elogios a esse trabalho, e estou começando a desconfiar que as pessoas acham que é a única coisa boa que fiz. Nunca se sabe. No entanto, seria uma injustiça desnecessária dizer que se trata de um trabalho escolar, quando na verdade se trata da tese padrão franco-brasileira que todo o mundo fazia. Ela tem dois méritos: primeiro, não está escrita inteiramente em jargão hegeliano. O segundo mérito é que eu acho que a ideia da tese é boa.

\section{Você tinha o Marx no horizonte?}

Era um Marx muito precário, mas tinha. O ponto de vista da tese é o do jovem Marx, a interpretação que ele faz da Fenomenologia do espírito, em que o conceito de trabalho é fundamental. E tinha um pouquinho do jovem Hegel de Lukács. Essas eram as minhas únicas referências. Vagamente, mas muito mal digerido como um outro horizonte, tinha algumas coisas de Giannotti, das Origens da dialética do trabalho. A perspectiva sobre Hegel, naturalmente, só poderia ser marxista, e ela foi se acentuando, no decorrer da redação, devido ao livro de [Gérard] Lebrun, La patience du concept. No limite era uma tese contra Lebrun, mas, ao mesmo tempo, ela o assimila, pois o seu livro tinha sido uma revelação para mim. Na verdade, o que eu pensava era: "como é que eu posso justificar o acerto involuntário do Lebrun?”. Eu fiz uma primeira redação dos capítulos iniciais, apareceu o livro de Lebrun, interrompi a tese e fiquei vários meses estudando Lebrun. É um grande livro, e eu tinha de explicar por que esse livro é bom, mesmo estando inteiramente errado: a ideia de que Hegel não é um filósofo doutrinário, essa é a sua ideia genial. Só que Lebrun centra isso na ideia de linguagem. Com essa descoberta ele acabou reduzindo Hegel e a dialética a um discurso, a uma façon de parler.
Durante dez anos você esteve empenhado num projeto sobre o "ABC da miséria alemã”. Em que consistia esse projeto e o que o levou a interrompê-lo?

Quando eu estava na França, escrevendo a minha tese, percebi que eu também, para variar, estava correndo por uma pista inexistente. Estava terminando uma boa tese, aliás fui preparado na USP para fazer isso, e tinha duas escolhas na volta ao Brasil: podia continuar fazendo a lição de casa, isto é, aquilo que os meus professores esperavam que eu fizesse depois do doutorado em Hegel. Teria de fazer uma livre-docência explicando a Lógica, de Hegel. Escolheria um problema, tentaria explicá-lo e mostraria como da Lógica se passa para O capital - o programa do “Seminário Marx", de Giannotti e de Ruy. Em parte eu até comecei a fazer isso, pois cheguei ao Brasil e dei dois anos de curso sobre a Lógica. Essa escolha seria a mais fácil. Por inércia eu faria um trabalho bem feitinho sobre a Lógica, seria útil etc.

A outra escolha, mais arriscada, exigia mais energia e mais coragem. Ao mesmo tempo que eu descobri o Brasil, começava a descobrir coisas sobre a história da Alemanha, que não poderiam entrar na tese, pois seriam consideradas historicismo, e eu não tinha ainda condições de juntar tudo isso. Quando descobri que o Brasil que eu estava estudando via Roberto [Schwarz] era uma sociedade nacional periférica, e que as sociedades nacionais periféricas, a partir do século XIX, tendiam a se assemelhar, como Portugal, Alemanha, Rússia, Irlanda, Itália, Áustria etc., isso foi uma "mina de ouro". E o que pensei? Antonio Candido é interessante para dizer o menos, Roberto idem. Não sabem e não dão a mínima para Kant, Frege e companhia. Aí tem coisa, devo estar no bonde errado. São esses 
"caras" que contam. Para bem ou para mal é a eles que se tem de referir para interpretar um objeto histórico específico, que é o único sobre o qual nós podemos falar: o Brasil. Pois só podemos falar do mundo através do Brasil, consolidando-se ou se desmanchando.

Por outro lado, se eu virasse um especialista em Hegel, que é um autor "quente", o que eu poderia ser? No máximo um bom professor de filosofia clássica alemã. Eu iria me aposentar deixando papers úteis para as pessoas que viessem depois - afinal o Departamento tinha sido feito para funcionar dessa maneira. Só que naquele momento já não me interessava mais fazer só isso, eu tinha de passar para o outro lado. Mas, para isso, eu estava completamente despreparado, não só no sentido escolar, estava mentalmente despreparado. Eu era um ótimo aluno da Filosofia, o queridinho de todo o mundo, mas, ao mesmo tempo, considerava-me um idiota completo, incapaz de dizer qualquer coisa interessante sobre qualquer assunto que não fosse Hegel, Nietzsche e cia. Poderia, é verdade, dar umas aulas sobre Saussure, Lévi-Strauss, Freud e Lacan. Mas todo o mundo podia e devia fazer isso, esses temas tinham virado um assunto escolar e profissional. E eu aspirava por uma vida intelectual menos rotineira, em que pudesse falar e escrever coisas que as pessoas do outro lado, julgassem interessantes e, sobretudo, que servissem para alguma coisa.

No entanto, eu não podia passar para o outro lado como se fosse fazer uma pós-graduação em sociologia ou literatura. Não iria ficar estudando Weber e Durkheim para, depois de vinte anos, escrever alguma coisa sobre industrialização no Brasil. Nem era meu propósito escrever sobre história política, econômica do Brasil. O meu propósito era pensar a cultura brasileira de uma maneira que não fosse o trivial dos estudos literários. E quem escrevia dessa forma era o Roberto, não havia outro. Roberto era completamente anômalo, porque era formado em sociologia, conhecia bem Marx, conhecia os frankfurtianos e tinha uma compreensão anti-ideológica da literatura. E pensei: o que posso fazer na mesma direção? Não seria por meio de uma graduação em sociologia ou em teoria literária. Tinha de fazer sozinho. E fiz com leituras indiretamente monitoradas por Roberto, que passou a ser uma espécie de referência permanente. Eu aprendia conversando com ele, e estudando o que ele estava escrevendo.

Ao ler os textos de Lukács (sobretudo os de filosofia clássica alemã e Hegel), eu fiz uma grande descoberta, grande para o tamanho da minha ignorância, é claro: Lukács tentou, mas não conseguiu, vincular filosofia clássica alemã e desenvolvimento desigual e combinado num país periférico. Ele afirmou que uma coisa tem a ver com a outra, mas não demonstrou como. Se eu demonstrasse, cumpriria o programa marxista, que era o da minha formação uspiana, e teria uma chave para compreender o vínculo entre vida mental e processo social nas situações periféricas, que, por sua vez - como o Roberto estava provando - , revelam a natureza do núcleo central.

O abandono desse programa ["ABC da miséria alemã”] foi estritamente circunstancial. Não renego nada e não há mistério: simplesmente não acabei. Eu queria explicar como funciona o discurso hegeliano e como funciona a dialética. Tratava-se de uma história da modernização através da intelligentsia, que procurava mostrar como se dá a passagem do iluminismo para a dialética, e como, já no iluminismo, há dialética. Comecei com os franceses e depois passei para a Alemanha, ou seja, tratei de como os franceses são refratados na Alemanha, e de como a dialé- 
tica apareceu para dar conta dessa refração, desse deslocamento. Então comecei com um ensaio sobre a invenção hegeliana da dialética dos intelectuais na Ilustração francesa, como isto era decantado numa espécie de "Questão de Método" e culminava no exorcismo do êxtase intelectual durante o Terror jacobino. Eu procuro mostrar como esse êxtase intelectual foi refratado na Alemanha, numa espécie de lógica interna fantasmagórica das ideias. Depois disso, eu trataria dos italianos e de Gramsci, passaria para a Rússia (embora o caminho real fosse o inverso), mostrando como os franceses e os alemães foram lidos por lá. Para isso, eu teria de estudar todos os publicistas, a radicalização da intelligentsia russa e, sobretudo, a figura do intelectual nos grandes romances russos do fim do século XIX, em Dostoiévski e Tolstói. Sem falar noutras periferias europeias. Até sobre Portugal escrevi alguma coisa e engavetei. Mas todo esse programa iria consumir uma vida inteira.

Havia, dessa maneira, um panorama mundial a ser estudado. E, nesse sistema de diferenças e continuidades, havia alguma coisa como um pensamento dialético dessa mundialização da cultura e do capital que era uma expansão diferenciada, pois tratava-se do centro e da periferia. Queria mostrar que esse estudo era feito por um brasileiro, ou seja, que se tratava da perspectiva crítica da periferia sobre o movimento das ideias quando se dá a expansão do capitalismo desde a hegemonia inglesa até o início do século XX. Feito isso, o meu foco passaria a ser o Brasil, e eu estava lendo sobre o Brasil, para fazer a junção e, portanto, a comparação sistemática. Num determinado momento, em 1982, pela primeira vez eu arrisquei dar um curso sobre filosofia e cultura no Brasil, no primeiro ano de filosofia. Em 1983, quando eu estava com o assunto razoavelmente arrumado em minha cabeça, a Folha de S. Paulo me pediu para resenhar o livro de Ruy [Fausto], e eu pensei: “Bom, agora eu vou entrar”. Obviamente eu não resenhei o Ruy, falei de um capítulo brasileiro do marxismo ocidental. Em 1984, comecei a estudar Cruz Costa. $\mathrm{E}$, para isso, havia uma continuidade: comecei por Cruz Costa, passei pelo Departamento de Filosofia, e cheguei aos clássicos locais e a formação da filosofia paulistana, ou seja, cheguei a Bento, Giannotti, Porchat e Ruy. Nesse momento, falei para o Roberto: "Essa é a hora do vamos ver. Se eu largar os alemães, eu largo um trabalho que está bem encaminhado. Mas, acho que é hora de arriscar - quem quiser que continue essa tarefa -, e vou tratar do assunto para o qual me preparei, que é o assunto de maturidade de todos nós - o Brasil". Dessa forma, fiz uma passagem que acho mais ou menos coerente. E o que me interessava era passar pelo filtro a ideia crítica de formação e o transplante cultural responsável pela minha própria constituição mental filosófico-uspiana. E larguei o “ABC da miséria alemã”. Não faltaram os comentários sinceramente desolados: "Esse cara larga a lógica, vai para a esquerda hegeliana, vai estudar filósofos menores, depois larga a história da filosofia, vai fazer sociologia das ideias na Alemanha, e depois passa para Cruz Costa?".

Seria possível falar de uma "filosofia brasileira"? Como você vê as relações entre a filosofia e a cultura brasileira?

Começarei pelo trivial: falar em filosofia brasileira é como falar em filosofia francesa, alemã, italiana etc., ou seja, a filosofia feita na França acaba gerando uma tradição pelo fato de ter sido feita na França, e não por ter vínculos atá- 
vicos ou sobrenaturais com algum espírito da terra ou coisa que o valha. Nesse sentido, a filosofia brasileira é o conjunto de publicações brasileiras sobre um assunto tradicionalmente classificado de filosófico pelos bibliotecários. Isso é a filosofia feita no Brasil, e ela não é distinta das demais por ser "brasileira". Dito isso, nem tudo está dito. A filosofia brasileira não é brasileira, ela é importada. Assim como a filosofia americana não é americana, é alemã. A assim chamada filosofia analítica americana, a filosofia neopositivista americana, é a filosofia alemã que, nos anos 30, imigrou para os EUA. Mas nem por isso a filosofia brasileira deixa de ser alguma coisa que tem um estilo próprio, e que este estilo responde por uma tradição muito particular de estudos cujo embrião se completou nos anos 60 no Brasil.

Esse embrião diz respeito ao transplante de técnicas intelectuais francesas de lidar com filosofia que se realizou a partir dos anos 30, isto é, a transplantação da filosofia universitária francesa que desembarcou em São Paulo sem maiores mediações. Trata-se de professores que chegavam nas classes do futuro Departamento e começavam a falar em francês como se estivessem em um liceu, ou em uma faculdade de província francesa, anunciando ato contínuo: "nesse semestre vamos estudar tal assunto (normalmente a ideia disso ou daquilo na filosofia de fulano ou beltrano), a bibliografia é essa, os temas de trabalho são esses, seminário é assim, dissertação se faz assim e não existem mais cursos panorâmicos, apenas monográficos". Com isto, a colonização começou a ser feita. Era uma colonização necessária e a seu modo progressista que fazia com que as pessoas, se desvinculassem de toda a tralha ideológica que se imaginava ser filosofia nas faculdades de Direito ou nos círculos amadores que filosofa- vam por conta própria na cidade. As pessoas se isolavam, rompiam com essa mentalidade municipal e passavam a se comportar como se fossem europeus. À primeira vista, nada mais desfrutável, mas foi dessa alienação que afinal provou ser produtiva que resultou o assunto que está nos ocupando agora.

A filosofia brasileira é um corpus que não precisa se apresentar como um conjunto de obras "originais" de filósofos brasileiros inspirados - isto é bobagem. Trata-se de um movimento coletivo que se cristalizou no final dos anos 60, quando as primeiras teses "europeias" foram concluídas. E esse estilo acabou sendo identificado como chato, morno e técnico, ou seja, filosofia paulistana, da USP. É a filosofia feita no Brasil em termos profissionais, e que por isso, é capaz de sustentar a comparação com o similar estrangeiro. E isso formou (e forma) alunos, público, leitores escolados e uma gama variada de publicações. Constituiu-se um repertório de referências bibliográficas, de temas a serem estudados, de maneiras de se fazer teses, de se dar aula e assim por diante. Esse repertório foi fundamental, pois, a partir de um determinado momento, foi possível dizer que a filosofia no Brasil funcionava, e que existia uma filosofia brasileira. Mas isso não quer dizer que haja uma lógica brasileira diferente de uma lógica da Oceania.

Dito isso, vamos para a segunda parte da pergunta: a da relação com a cultura brasileira. É uma constatação dolorosa, mas a filosofia é uma espécie de primo pobre na formação do sistema cultural brasileiro. É bom frisar isso porque as pessoas do ramo ficam muito estomagadas com essa afirmação, achando que estão sendo menosprezadas, subestimadas, tachadas de irrelevantes etc. Quando não se trata disso, não se trata de uma desqualificação profis- 
sional e intelectual. Estas pessoas são competentes, até demais. Para entender essa circunstância, temos de nos compenetrar do seguinte: a cultura de um país periférico como o Brasil está inteiramente centrada na ideia de que através de gêneros e formas inescapavelmente europeias - o romance, a poesia, a pintura, a arquitetura etc. - , trata-se de exprimir a verdade original de uma experiência local. Ou seja, só é relevante a forma que promove essa reinterpretação, que seja um instrumento de descoberta e revelação do país. Tudo se passa então como se estivéssemos condenados a essa figuração da experiência, à necessidade de sermos apresentados incansavelmente à nossa própria e desconhecida imagem, por isso mesmo uma imagem inacabada. É preciso entender que isso não faria sentido em sociedades nacionais consolidadas como a Inglaterra ou a França. Nesses países não há nenhuma insegurança quanto aquilo que se é, e quanto a imagem que deve se projetar e construir. É como se a nossa inteligência local só funcionasse na medida em que fosse empurrada por esse imperativo de configuração. Daí o caráter central da literatura. Todas as formas que possam tornar narrável essa experiência ainda completamente embrionária possuem uma função estruturante. Isto faz com que o teor de verdade dessa experiência eminentemente literária seja puxado para cima, desde que ela cumpra essa função, daí também uma certa tendência sentimental ao realismo miúdo de simples fidelidade à cor local, que nos empurra de volta para a miopia localista.

Ora, qualquer tipo de atividade que discrepe dessa intenção está estruturalmente condenado a ter um papel subordinado. A filosofia, no nosso caso, padece duplamente dessa restrição. Na primeira parte da resposta, nós tínhamos definido a filosofia como uma rotina intelectual que se cristalizou em uma determinada instituição e numa circunstância histórica precisa. É o alargamento e o aprofundamento dessa rotina intelectual que, como método de estudo, forma aquilo que chamamos de cultura filosófica funcionando no Brasil, independentemente dos talentos individuais. A existência desse lugar subalterno deve-se ao fato de que essa cultura filosófica institucional, necessariamente universitária e profissional, é por definição, senão incompatível, pelo menos indiferente a esse projeto. Ela é inadequada porque a filosofia profissional, e não há outra sem retrocesso doutrinário e antimoderno, não é mais nem pode ser uma filosofia figurativa, isto é, não tem mais condições de descrever a experiência real como era sua ambição na Era Hegel, e de transpor essa experiência real para o plano conceitual. Ora, no Brasil a literatura fez isso de maneira supletiva durante mais de um século e, depois, foi deslocada e recolocada no seu devido lugar artístico. Como diz Antonio Candido: era uma literatura de incorporação e passou a ser uma literatura mais especializada, cumprindo o seu destino estético, sem abdicar no entanto daquela sondagem incontornável da experiência local.

Com o tempo e as nossas instituições universitárias, a literatura foi substituída pelas ciências sociais e pela economia política. A interpretação do país passou a ser feita pelo ensaio sociológico - científico e universitário. Portanto, a sociologia também foi uma figuração do país. E como a filosofia é estruturalmente incapaz de dar conta desse projeto, tem de ter necessariamente uma vida marginal. Para prosperar como uma especialidade acadêmica séria, ela teve de se desvincular desse projeto de figuração da experiência nacional. A filosofia moderna, a filosofia profissional, abandonou, como uma espécie de 
resquício doutrinário dogmático, essa pretensão de ser uma espécie de figuração do mundo no sentido mais amplo. Por isso que, quando a filosofia profissional apareceu em São Paulo e se alastrou por todo o país, ela provocou um certo escândalo. Porque parecia um bando de pessoas completamente alheadas, de funcionários medíocres, explicadores de textos, assimiladores de textos, de costas para o país. Funcionários que não tinham nada a dizer porque se recusavam a tanto por escrúpulos intelectuais, ou seja, porque não eram demagogos, não eram doutrinários e porque achavam que não podiam desentortar o país em nome de cosmovisões filosóficas. Portanto, a filosofia profissional necessariamente teve de ocupar esse lugar secundário. Restaria explicar o seu crescente sucesso de público nos últimos vinte anos. Mas isso já é uma outra história e como nada me foi perguntado a respeito... Suspeito que algo tem a ver com o tipo de autoajuda demandada pelo colapso da modernização.

O Departamento de Filosofia era movido por dois impulsos, um consciente e outro não. Nossa imodesta consciência técnica nos confirmava na seguinte certeza: "somos os melhores, qualquer questão de método é conosco mesmo - até os sociólogos recorrem a nós. Somos considerados filósofos e a filosofia é o topo do topo. Somos também estudiosíssimos e articulados". Era a superstição acadêmica de que o filósofo sabe de tudo. Em função disso, todo o mundo estudava pra burro. Mas eu acho que havia ainda uma outra motivação informulada: a de que aquele enclave fazia parte de um esforço coletivo de construção nacional, mesmo que ninguém falasse disso. E nem poderia, porque seria mal visto. No entanto, acho que essa convicção semiconsciente era uma espécie de energia social que empurrava o estudo. Mas isso que estou chamando de "sistema cultural filosófico", esse conjunto de obras, de produção de leitores, de cursos, de rotina intelectual foi impulsionado por esse ânimo construtivo. E quando se formou, e começou a se reproduzir de maneira ampliada, esse élan começou a definhar. E o que se passou a fazer? Seguimos tocando o serviço bem feito, fazendo intercâmbio internacional, colaborando com eventos - que são pautados por um sistema de efemérides da indústria cultural - e pronto. Insisto que isto não passava pela cabeça de ninguém. Imaginava-se que ao passar um semestre debulhando os Livros Analíticos de Aristóteles, alguma coisa no país e no mundo iria mudar. Agora não, é preciso fazer bem feito para ganhar uma bolsa, ir para os EUA ou Alemanha, voltar e publicar um livro, isto é, enturmar-se na rotina mundial. E a diferença que ia ser feita quando esse sistema se completasse não veio, e pegou todo mundo no contrapé.

\section{E veio a ditadura...}

Não, a ditadura não afetou. Pelo contrário, ela retardou esse processo, porque o Departamento teve de se encolher, fechar-se em copas e estudar mais ainda. Curiosamente, quando a ditadura começou afrouxar no fim dos anos 70, deu-se o grande apogeu da filosofia brasileira. Com o refluxo da ditadura, imaginou-se que o país iria virar do avesso, que iria reatar com o que era antes de 1964, que o país iria voltar a ser inteligente, que iríamos dar um salto e completar a agenda de dois séculos de atraso. Na filosofia, imaginava-se isso a partir do que era feito na SBPC, com os cursos que se multiplicavam na universidade, com a SEAF [Sociedade de Estudos e Atividades Filosóficas] e a ANPOF [Associação Nacional de Pós-Graduação em Filosofia], e 
com a volta da filosofia ao secundário. Então, de 1974 até 1984, houve um auge que escamoteou o fato de a filosofia já estar rodando em falso, mas ninguém sabia disso. O país estava avançando, havia fordismo periférico, dos sindicatos do ABC estava saindo um partido dos trabalhadores e o PMDB havia se renovado. E, graças aos militares, com a multiplicação das universidades federais, havia cursos de filosofia no Brasil inteiro. Então a expectativa em relação ao país que viria depois do fim da ditadura, e o fato de a filosofia estar compassada com isso, era enorme. Tanto é que nós achávamos que o problema era a democratização do poder universitário, e que já havia ocorrido uma espécie de contaminação de classes, uma proletarização da universidade. Mas não, simplesmente a classe média havia sido rebaixada e tinha aumentado mesmo na falta de um motor formativo, a filosofia, que em princípio não podia atender aos imperativos da figuração da experiência nacional, no entanto prosperou. E qual foi o critério desse florescimento? Fazer teses inteligentes sobre assuntos clássicos. Mas quem fazia essas teses inteligentes, tecnicamente competentes, não tinha muita perspectiva a não ser a de continuar indefinidamente fazendo teses competentes. Até então havia a perspectiva de que essa competência iria se espraiar, esse era o projeto da Faculdade. Lembremo-nos de Antonio Candido divergindo de Cruz Costa, em nome de uma espécie de convicção iluminista acerca do funcionamento da inteligência. Quando Cruz Costa, na melhor tradição da filosofia pré-crítica, dizia: “o que importa é uma orientação filosófica que dê um rumo, e, que nesse rumo, ponha feijão na panela do povo", Antonio Candido replicava de duas maneiras, uma tradicional e outra iluminista. A tradicional era a seguinte: "temos de ter um bom curso de filosofia porque quando um brasi- leiro puder dar uma contribuição original sobre os temas universais da filosofia, nós teremos dado um passo gigantesco rumo à civilização que caracteriza o concerto das nações". Havia o outro lado, o lado iluminista, que estava na origem daquele impulso do qual falei anteriormente. Então dizia o seguinte, nos anos 40: "Cruz Costa, você se enganou. Nós temos de tratar dos temas universais. E estou certo de que uma boa tese sobre Fichte produz o seguinte efeito: torna a inteligência daquele que fez a tese e daqueles que podem decifrá-la incompatível com a iníqua desigualdade social brasileira". Portanto quem aprende a pensar decifrando um clássico (e a filosofia dessa maneira é sempre progressista), lendo Platão ou Fichte, vai mudar o país. Foi essa energia, essa imaginação de que quem estuda bem estará colaborando patrioticamente para reduzir o grau de iniquidade local, que empurrou a filosofia na Faculdade.

Que conceito(s) de sua reflexão você destacaria como o(s) mais representativo(s) da sua produção filosófica? Pediríamos que você nos contasse como ele(s) surgiu (ou surgiram) em seu trabalho e como o(s) vê hoje.

Bom, como se diz em assembleia, essa proposta está prejudicada. Não tenho reflexão filosófica própria e original e, portanto, não posso ter conceitos que orientem essa reflexão. Não é coqueterie, não estou fazendo charme ao dizer que nunca fiz filosofia. Não posso nem dizer que pretendi fazer filosofia porque, quando entrei na Faculdade, a primeira coisa que me disseram foi: "Você não vai ser filósofo. Isso não existe. Filosofia não tem conteúdo e não é matéria transmissível. Esqueça isso. Você será um técnico em bibliografia filosófica". Quem alimentava essa preten- 
são de ser filósofo era o pessoal da linha Tobias Barreto e Miguel Reale ou Vicente Ferreira da Silva, entre outras sumidades.

Em Sentimento da Dialética, comentando a perspectiva globalizante que a ideia de dialética assume em Roberto Schwarz, você afirma: "Roberto não só ia anotando o alcance mundial de nossas esquisitices nacionais como ia construindo uma plataforma de observação a partir da qual objetava esta mesma ordem universal. O que reconhecerá em ato no pensamento literário de Machado. Estava assim lançada a base de uma Ideologiekritik original. O mesmo chão histórico que barateava o pensamento e diminuía as chances de reflexão - pois aqui se desmanchava o nexo entre ideias e pressuposto social, o que lhes roubava a dimensão cognitiva - devolvia a faculdade crítica com a outra mão, fazendo nossa anomalia expor a fratura constitutiva da normalidade moderna". Quais os alcances de uma tal Ideologiekritik, e como você vê este conceito hoje?

Eu não sei se explico bem esse termo Ideologiekritik, acho até que renunciei a defini-lo no texto. Vou explicar um pouquinho para dizer o que há de original no Roberto e o que eu tinha na cabeça quando estava redigindo esse trecho. A crítica da ideologia aparece quando os clássicos do marxismo reinventam a palavra "ideologia” e usam a ideia de "crítica", advinda do século XVIII, do Iluminismo. É bom não esquecer a palavra “crítica” está presente no subtítulo d'O capital: "Crítica da economia política". Portanto não se trata de doutrina, mas de Crítica. Com Kant, a Crítica passou a ocupar o lugar da Teoria, como ele mostra na Crítica do juízo - e é o mote da grande tese de Lebrun, Kant e o fim da metafísica.

Quando emprego o termo, estou pensando sobretudo na formulação dos frankfurtianos. Para eles, o termo ideologia não é mais pejorativo, a ponto de constatarem que a ordem capitalista regrediu tanto que nem mais ideologia produz. A ideologia sempre tem um fundamento de verdade. Ela não é inteiramente falsa, nem é inteiramente verdadeira, não é um mero engodo. A ideia de ideologia como uma manipulação de massa, em que se ludibria os indivíduos, é uma ideia iluminista — é denúncia da superstição. A novidade do materialismo de Marx é que ele rompe com essa tradição iluminista, com a "história do erro", com a ideia de que a difusão das luzes dissipará as trevas. E por si extrai da filosofia clássica alemã a ideia substantiva de "aparência", que se converterá na ideia materialista de "aparência social necessária”. A simples crítica raciocinante (como queriam os iluministas) não faz com que essa aparência se dissolva no ar.

Quando se fala em ideologia, pensa-se em racionalização. E não se trata apenas disso. Repito que a matriz da ideia de crítica da ideologia é o idealismo alemão, até porque ele mesmo é a transposição (não deliberada, é claro) do funcionamento real desse processo social de produção da ilusão. O primeiro a se dar conta desse novo âmbito material da Crítica foi Hegel. A fonte de Marx, a ideia de crítica da ideologia, é a ideia de reflexão tal como ela aparece na Fenomenologia do espírito, de Hegel. O que faz a consciência, segundo Hegel? Ela se ilude também, ela é uma fábrica de ideologias. Mas ela se distingue pela seguinte peculiaridade: a reflexão. Essa reflexão vai reaparecer em Marx, só que de maneira a um tempo fantasmagórica e real, objetiva. É o capital que se refere a si mesmo, o feti- 
che do fetiche. Ele funciona como se fosse uma consciência: valoriza-se a si mesmo, refere-se a si mesmo, mede as suas quantidades etc.

Em Hegel, a consciência, ao mesmo tempo em que é uma fábrica de ideologias, é a crítica dessas ideologias, porque ela se corrige a si mesma. Ela é a sua própria medida. Na formulação do Hegel: "ela é o seu próprio conceito". Ela afirma uma verdade sobre si que até então desconhecia, e, ao expor essa verdade, ela a compara com a sua experiência dessa mesma verdade e, desse juízo passado sobre si mesma emerge algo como um sentimento dramático de seu descompasso, de sua divisão. Negação interna que procura resolver por uma nova operação crítica comandada pelo seu próprio padrão de medida. Portanto a ideologia e a falsa consciência não são inteiramente falsas, há um momento de verdade que é inconsciente e obscurecido, porque há uma relação de poder e de dominação na ideologia, o impulso do autoengano, da racionalização etc. De sorte que o conceito de Ideologia por assim dizer confia numa verdade substantiva que existe, e é expresso por ideias, que por sua vez são eminentemente práticas. Por isso a ideia que está embutida na ideologia é a que Kant tinha em mente, que é sempre ideia da razão, e necessariamente prática, pois tem a ver com sua realização ou não no mundo.

O que é chamado de ideologia burguesa, que vai do cristianismo já totalmente secularizado e racionalizado (no sentido weberiano) até a arte, passando pelo direito natural e pela filosofia, é uma espécie de repositório de verdades da humanidade em seu progresso rumo à emancipação. Então justiça, liberdade, igualdade, fraternidade, universalidade, beleza são ideias verdadeiras. Só são falsas na medida em que na ordem burguesa se apresentam como já realizadas. Foi o jovem Marx quem começou a dizer isso: "a crítica da ideologia nada mais é do que obrigar o mundo a confessar aquilo que ele já é, não estou acrescentando nada", ou seja, na hora em que o mundo se confessa, ele se corrige. E a revolução é essa confissão, em que ele reencontra a sua verdade, expressa na inconsciência da ideologia. A ideologia, portanto, transcende a realidade, está para além da realidade. A realidade está aquém, e a ideologia é falsa porque é uma promessa não cumprida. A crítica da ideologia é uma operação lógico-social, crítico-revolucionária - como dizia o jovem Marx - , que permite que essa verdade se reencontre consigo mesma. Ou seja, no momento em que aparece, implica necessariamente em uma transformação social. Há, dessa forma, uma falsa universalidade que, confrontada com a sua realização defeituosa, por assim dizer se regenera coincidindo afinal consigo mesma. O que é isso? Uma pressuposição muito forte que implica numa concepção otimista da história. Trata-se em suma de uma filosofia da história. E a configuração derradeira dessa mola secreta da crítica da ideologia, sua incessante correção interna, é a famosa contradição entre forças produtivas e relações sociais de produção. A revolução é essa reviravolta, tal qual uma experiência da consciência, no sentido hegeliano. De modo que há um sistema de universais que constitui o arcabouço da civilização liberal burguesa clássica, do século XIX até a grande crise entre 1914 e 1939, no interior do qual a crítica da ideologia funciona justamente como o impulso de realização do ideário burguês. Por isso que, nessa vertente originária do materialismo, o capital e a burguesia são progressistas por definição, liberalismo e socialismo se implicam mutuamente. Nesse sentido, a crítica da ideologia funciona como uma negação 
determinada, no sentido hegeliano. No caso de Hegel, por se tratar de uma filosofia especulativa, essa identidade do conteúdo consigo mesmo já está assegurada, vai haver necessariamente um happy end. Por isso, quando começa a Fenomenologia do espírito, nós já sabemos que tudo vai dar certo, assistimos à consciência se educando através de sucessivas crises movidas pela crítica imanente de seus castelos ideológicos, como nessa toada o negativo das perdas se converte em positivo, a consciência vai se enriquecendo à medida que é desenganada.

Mutatis mutandis, com o capital é o mesmo enredo. Ele permite tecnicamente superar pela primeira vez a escassez, e, portanto, permite à humanidade encontrar-se consigo mesma e encerrar a sua pré-história. A sua pré-história é a história dessas ilusões, a história de promessas emancipatórias de justiça, liberdade, igualdade etc. Mas uma emancipação por enquanto apenas negativa, que os sociólogos chamarão de modernização. E ninguém pode dizer que é contra tais promessas, até mesmo em relação à promessa da propriedade, pois é no socialismo que a propriedade vai se realizar como tal. Dessa forma, há um processo movido a ilusão, mas que traz consigo o germe da sua satisfação interna. A crítica, assim, é uma comparação consigo mesmo, como se o ideal burguês clássico fosse constantemente posto à prova e se saísse bem sempre dando um passo adiante.

Ora, no caso de Machado de Assis, Roberto Schwarz não pensou mais nesses termos, quer dizer, nos termos de uma boa superação. O que ele descobriu? Que a idiossincrasia, a originalidade e a genialidade de Machado permitiram pela primeira vez verificar que a crítica da civilização burguesa, o que os clássicos chamaram de crítica da ideologia, estava funcionando de maneira diferente.
Para Roberto, a razão pela qual a Ideolologiekritik funcionara até então coerentemente na Europa liberal, mas não no Brasil não estava no fato de que a experiência periférica da coexistência sistêmica de capitalismo e escravidão falseava a própria vigência dos padrões civilizatórios da idade liberal burguesa. O que ele está dizendo é o seguinte (e é isso que tento dizer no texto citado por vocês): nós temos a possibilidade, através de Machado, de entender o que está acontecendo na Europa. E o que estava acontecendo na Europa, na época de Machado, era a derrocada da civilização liberal burguesa. Para Roberto, os dois termos da crítica da ideologia, o universal e a sua realização particular, como que se relativizam e rebaixam mutuamente.

Dessa forma, não era porque éramos atrasados, coloniais, escravistas etc., que estropiávamos a universalidade do programa liberal burguês. É porque ele já estava contaminado desde a raiz, isto é, a nossa experiência demonstrava o formalismo da civilização liberal capitalista, mostrava que ela podia conviver com não importa qual tipo de barbaridade, como a escravidão por exemplo. O caráter formal, ou seja, a equivalência generalizada e a abstração, fez com que essa civilização pudesse conviver com todos os tipos de "retrocessos" que, na verdade, nos tornavam seus contemporâneos. De modo que o motor da crítica clássica da ideologia já estava começando a falhar e foi, pouco adiante, desmoronar com o nazismo, ou seja, com a crise terminal da civilização burguesa, que começou a madrugar com o imperialismo. Dessa forma, Machado, em seus próprios termos, estava refratando a experiência imperialista do desmoronamento da civilização liberal. A norma universal burguesa foi desmoralizada pela sua particularização local, que ela no entanto ao mesmo tempo desqualificava. 
Isto aparece quando as duas coisas se juntam e culminam na comédia ideológica de Machado, que é a relativização recíproca desses dois lados. Isso não estava nos clássicos, e apareceu pela primeira vez com os frankfurtianos, isto é, com o colapso da civilização burguesa quando caíram os dois lados: a norma ideológica geral e o impulso de elevar a realidade ao seu próprio padrão imanente. Consta que Horkheimer teria dito que falar em Negação Determinada ou Ideologiekritik diante da ruptura histórica representada pelo III Reich parecia-lhe uma indecência. Então a crítica progressista da ideologia burguesa caiu por terra, o que Machado anteviu e foi tirando por aqui as consequências. Como artista, ele era radicalmente crítico em relação ao capitalismo, mas já não podia mais ser linearmente progressista. Se o fosse seria mais um Silvio Romero. Daí a invenção satírica do "humanitismo", uma salada grotesca da fraseologia burguesa mais avançada para sacramentar barbaridades cá e lá. É nesse sentido que a crítica da ideologia foi renovada. Por isso o sexto sentido do Roberto foi lá e acertou, até hoje fico impressionado.

Também em seu livro Sentimento da Dialética, você afirmou: "Uma vez exposta a raiz social da volubilidade narrativa, a alternância prática de patrocínio oligárquico e negócios burgueses, estava montado o esquema histórico de que carecia o crítico, a forma objetiva exigida pelo programa dialético traçado por Antonio Candido nos termos em que vimos Roberto Schwarz interpretá-lo. Repetindo: isso quanto a primeira acepção de dialética consagrada pela tradição materialista que manda procurar na configuração artística a estrutura social sedimentada. Quanto à segunda acep- ção que estamos dando à palaura, a reversibilidade caprichosa de norma e infração, acabamos de verificar que ela vinha fazer justiça à sensação de dualidade que o Brasil incessantemente desperta". Seria essa um boa apresentação do conceito de dialética de que você se utiliza? Tal conceito guarda afinidade com a noção de "dialética negativa" de Adorno?

É uma boa ilustração, mas não guarda afinidade com Adorno. Uso, de vez em quando, o termo "dialética negativa" para lembrar que o esquema evolutivo progressista, o que se entende por dialética no marxismo clássico, não funciona no Brasil. Isto é, Lukács não funciona. Explicando o Roberto, num determinado momento do Sentimento da dialética, relembro porque o Machado não é realista no sentido lukácsiano. Como eu não tinha outro termo, acabei usando "dialética negativa". Roberto mostra como essa alternância da norma burguesa e infração da norma burguesa, mas sobretudo a repetição desse mecanismo, não leva a lugar nenhum. Porque a forma machadiana de enquadrar estetica mente a experiência brasileira já havia revelado que não haveria esse passo adiante. E, na sociedade brasileira, essa "superação" do passado colonial escravista deveria marchar na direção de uma sociedade de classes à europeia - o pressuposto do grande realismo. O que acabou não ocorrendo e Machado intuiu de saída. De sorte que o grande realismo seria falso no Brasil. Na passagem de Iaiá Garcia para Memórias póstumas de Brás Cubas, (sempre segundo Roberto) há um caminho representado por Estela, a personagem que recusa a desmoralização inerente à sociedade senhorial - "a taça do favor já estava transbordando". Estela seria o embrião da narrativa realista burguesa europeia. Como ela escapa de um 
arranjo da matriarca Valéria e vai ser professora, seria possível imaginar que o próximo romance de Machado seria propriamente realista, em que há classes configuradas e a possibilidade de carreira social fora do patronato. Segundo Roberto ele deve ter pensado: "isto, no Brasil, é falso, essa estrutura patriarcal vai se metamorfosear e reproduzir". A trama realista, que é a imagem mais enfática daquilo que os clássicos na Europa, de Hegel a Lukács, chamaram de dialética entre indivíduo e sociedade - esse drama dialético de oposições, a hélice que empurra o romance -, não iria acontecer no Brasil. Na bela expressão de Roberto: "essa hélice empurra em direção ao nada". Nesse sentido, a dialética clássica fez com que o pensamento progressista brasileiro, em uma certa época, desdenhasse Machado e fosse procurar Lima Barreto - o que é um engano total.

Então eu uso "dialética negativa" para caracterizar uma alternância, um certo girar em falso entranhado na lógica da sociedade brasileira. Com isso, eu estou abusando um pouco da maneira pela qual Hegel descrevia o caráter inconclusivo da ideia de reflexão nos clássicos alemães, sobretudo em Fichte e Kant. Nestes, a imaginação balança de um lugar para o outro e não produz nenhum resultado, não avança. No caso de Machado, foi isso o que eu quis dizer. Se eu quisesse ter complicado a minha vida, poderia ter dito que não tinha nada a ver com a dialética negativa de Adorno, que não é propriamente alternância indefinida que não se resolve. Só que essa alternância inconclusiva no Machado tem um efeito mimético exemplar, e essa é a demonstração de Roberto. Machado usa recursos não realistas, vai ao Setecentos inglês e aos moralistas franceses do século XVII para obter uma representação "realista" da matéria brasileira que lhe interessava retratar estruturalmente. Por outro lado - e é aí que eu poderia ter complicado a minha vida - , eu poderia dizer: no fundo, não há dialética.

Em sua história, a filosofia manteve uma relação estreita com as ciências e o saber científico. Tal relação permanece até hoje? Como ela se dá na atualidade?

Isso é pergunta padrão para dois terços das pessoas que se ocupam com filosofia. Bom, como não sou filósofo, e como não tenho me ocupado muito dessas questões sobre a relação entre filosofia e ciência, vou sair pela tangente. Vou dar uma resposta pragmática. Voltarei ao meu realejo uspiano, para, depois, falar da atualidade.

Uma das grandes revelações da "formação" dos franceses na USP foi a dissociação entre filosofia e ciência. A meditação filosófica sobre a ciência e a epistemologia passou a ter um caráter inteiramente subsidiário e nada decisivo, embora para uso doméstico, ocupasse um lugar no currículo quase tão central quanto a história da filosofia. Em princípio, a epistemologia não teria mais nada a dizer para um cientista. Isso faria parte da modéstia, e da futura timidez uspiana, no sentido de que nada do que se pudesse falar de matemática e de física, de Aristóteles até a teoria quântica, teria algum interesse para quem faz ciência.

A relação intrínseca da filosofia com a ciência é, para nós, um problema essencialmente histórico. Houve um momento em que elas eram indiscerníveis, dos gregos até Descartes e Leibniz. Esses dois foram os últimos que eram cientistas e filósofos indistintamente, no sentido original do termo. Com Kant, isso desapareceu. O primeiro a dizer isso de maneira não tematizada explicitamente, dentre os franceses que chegaram aqui, foi [Jean] Maugüé. E quem 
disse de maneira sistemática foi Lebrun. Ele mostrou que, com Kant, a nossa relação congênita com a ciência desaparece, isto é, a filosofia passa a não ter mais nada a dizer para quem faz ciência. Tanto é que é possível fazer uma prova empírica e sociológica elementar: quando alguém das ciências exatas ou biológicas chama algum filósofo para falar, não quer ouvir nada sobre biologia, Darwin ou Einstein, quer ouvir filosofia, quer saber quem foi Platão, Aristóteles, Freud etc. Os cientistas conhecem seu métier, querem mesmo é cultura geral. E Lebrun mostrou uma coisa que é daquelas que abrem a cabeça das pessoas que começam a fazer o curso de filosofia: por que Kant se tornou obscuro? Ele não era obscuro. Na fase pré-crítica ele escrevia muito bem, até parecia um filósofo francês, de tão claro que era. Isso porque não havia ainda divisão entre filosofia e ciência. A rigor quem cuida de filosofia a partir de Kant, não pode enquanto filósofo saber positivamente de nada: aliás esse nada é o seu assunto real, como sabia qualquer romântico alemão.

Quando a filosofia, para Kant, deixa de anunciar o saber, torna-se possível a reflexão, não só propriamente epistemológica (originalmente, Teoria do Conhecimento), como sobre a epistemologia e sobre ela mesma - com a história da filosofia. Porque ela se separa da ciência e passa a refletir sobre as suas próprias categorias, os conceitos puros do Entendimento e por aí afora. Portanto, como dizia Lebrun, Kant torna-se complicado e ilegível, porque já não estava mais comunicando um saber positivo. Ora, quem faz epistemologia tem de admitir que está cultivando um gênero filosófico reflexivo, de teor histórico e sem nenhuma pertinência para quem produz ciência. Quando muito, é possível refletir sobre a prática da ciência como uma prática social. Mas daí já não é mais o filósofo que faz isso. Dessa forma, o filósofo já não tem mais nada a dizer para o matemático, para o biólogo, que estão "se lixando" para ele. Tornando-se uma disciplina universitária entre outras, a filosofia além do mais ocupa-se mesmo é dela mesma - a ideia de crítica kantiana - às voltas com os conceitos puros da razão, como Kant a definiu. E isso vai de Kant a Husserl, passando por Frege e Wittgenstein.

Quando essa triste equação se inverte, temos Habermas. Ele começa a imaginar algumas ciências especiais, que são mais do que ciências. Dá como exemplo Freud, Piaget e outros. Essas ciências têm um momento reflexivo em que, no interior da sua própria produção conceitual, refletem sobre isso como se mimetizassem a filosofia. Nesse momento talvez o filósofo tenha alguma coisa a dizer. Mas isto é conversa fiada, não dá para acreditar. A ciência como fenômeno social é um bruta assunto. Mas essa filosofia profissional que conhecemos não tem nada a ver com isso. Talvez a Teoria Crítica dos frakfurtianos, entendida num sentido muito amplo, tivesse algo a dizer. Mas não é filosofia, nem sabemos mais se ainda existe. Daí haver alguma coisa a se dizer sobre o funcionamento contemporâneo da ciência, e, principalmente, sobre seu caráter de tecnociência, isto é, mostrar o momento em que ela virou fator de produção. Mas a partir daí, o quê? Fazer epistemologia de um fator de produção? É brincadeira! Dizer que há uma relação dialógica na produção da ciência, e requentar Pierce, Thomas Kuhn e companhia? Que a comunidade científica está mudando de paradigma? Ora, essa comunidade vai olhar e dizer: "Ah? Tá bom”. Agora, se examinarmos o funcionamento da tecnociência, a coisa muda de figura, pois o debate passa a ser político. Quando nosso patrimônio genético é cotado em bolsa, é preciso ver que tipo de ciência se está fazendo. 
Desde Hegel, no século XIX, trava-se um debate sobre o fim da arte, sobre um possível desaparecimento do fenômeno estético em nossa sociedade. Como você se posiciona em relação a esse debate?

Hegel nunca falou que a arte havia acabado, sobretudo porque foi contemporâneo do apogeu da arte na Alemanha. Ele simplesmente disse o que seria a arte do futuro: que a arte não teria mais nada a ver com o absoluto, isto é, que a arte não funcionaria mais do mesmo jeito que funcionou na sociedade medieval ou na sociedade antiga. A sua expressão para isto é: "Os joelhos, diante de uma obra de arte, não se dobram mais". Daí o caráter farsesco das enxaquecas estéticas de Mme. Verdurin. Trata-se do processo de dessacralização da arte como instituição. Mas, ao mesmo tempo, essa dessacralização da arte implicou em sua autonomização, ela passou a ser um objeto entre outros, passou a ser consumível. Beethoven foi o primeiro a pensar num público mais ou menos anônimo como futuro mercado, apesar de seus patrocinadores aristocráticos. No momento em que isto ocorreu, a arte foi se tornando cada vez mais o seu próprio assunto, na maneira hegeliana de entender o fenômeno. É por isso que Hegel chamou a arte romântica de dissolução da arte, ou seja, que havia nela um predomínio do arranjo formal sobre a experiência enfática da qual, a princípio, a arte tinha sido o veículo privilegiado. Portanto a arte, para ele, iria prosperar, mas não mais como o princípio cristalizador da experiência fundamental da verdade. O problema era esse: ela não teria mais nada a ver com a verdade.

Mas deixemos de lado essas altas paragens especulativas. Acho que seria bem mais interessante precisar o foco e escapar das generalidades filosofantes recorrendo à pra- ta da casa, por exemplo, para continuarmos em família, o debate entre a Otília [Arantes] e o Roberto [Schwarz], documentado em dois artigos, sobre a dimensão estética da arquitetura moderna. (Mutatis mutandis, o mesmo desencontro entre de novo o Roberto e Iná Camargo Costa sobre o juízo estético no teatro depois de Brecht.) E isso tem a ver com a segunda parte da pergunta, com o desaparecimento ou não do fenômeno estético na sociedade contemporânea. No caso da arquitetura contemporânea, quer dizer depois dos modernos, Otília é categórica: desapareceu. E é disso que se trata. No comentário que Roberto fez do trabalho dela, disse mais ou menos o seguinte: "Concordo inteiramente com a sua análise da dissolução do movimento moderno arquitetônico, mas, uma vez esgotado esse movimento, que por sua vez havia incorporado o avanço da vanguarda artística - sobretudo a construtiva -, qualquer que seja o diagnóstico, ele deixou um acervo atrás de si”. Era isso mesmo que Otília estava discutindo, o que significa dizer que a arquitetura moderna brasileira representa um dos maiores patrimônios arquitetônicos a céu aberto que se conhece. "Então o que a gente faz com isso?", perguntou Roberto. Com essa pergunta, ele queria dizer que mesmo que como tendência histórica e estética o movimento arquitetônico moderno não tivesse mais futuro, as obras de qualquer modo ficaram. E mais, continuava achando que tal acervo, brasileiro e internacional, era ainda uma senha para uma ordem social superior como queria o programa moderno. E o que se faz com essas obras, do ponto de vista da sua substância artística? São obras belas, bem realizadas - em suma, são obras de arte. Roberto dizia ainda que, quanto ao movimento moderno, ele usava a distinção adorniana entre ideologia e sua realização, ou seja, que a ideologia só é falsa quando 
ela se apresenta como realizada, não em si mesma. Ora, segundo Otília não se poderia sem mais, sobretudo em arquitetura, dissociar "projeto" e realização. "Mas o problema" - insistia o Roberto - "é que essas obras que restaram como relíquia do movimento moderno carregam e preservam uma espécie de semente crítica, que acende a imaginação utópica das pessoas, e, por isso, são e continuam belas. $\mathrm{O}$ esgotamento do movimento moderno não anulou esse efeito. Você [Otília] detectou uma tendência histórica, mais uma ironia objetiva por assim dizer clássica. Sendo o movimento moderno, em princípio, declaradamente antissistêmico, ele acabou se convertendo inteiramente no seu contrário afirmativo, integrou-se e tornou-se funcional, como você demonstra. Quando o capitalismo mudou, ele morreu. Posso até concordar com isso, mas diria que você identificou uma tendência, analisou sua reversão e depois deixou as obras de lado. E, ao deixar as obras de lado, você abdicou de decifrar na beleza da obra de arte, que é o edifício arquitetônico moderno, a promessa de uma emancipação futura. Você deixou de decifrar o curso do mundo através da obra de arte. E essas obras, malogradas ou não, são necessariamente a cifra do nosso tempo".

E mais: "Você conclui, portanto, que na arquitetura, pelo menos depois da falência do movimento moderno, a ideia de experiência estética seria no mínimo um equívoco. Quem imagina estar experimentando uma espécie de apogeu, ou de intensidade estética relevante, diante de um edifício moderno, ou não, está enganando a si mesmo. É essa a sua conclusão?". Resposta: "É isso mesmo". Ora, não se pode avaliar o interesse da resposta - e essa conversa continua - sem levar em conta que se trata em primeiro lugar de arquitetura, ou melhor, de arquitetu- ra depois da grande ruptura produzida pelos modernos numa quadra histórica crucial.

O que Otília estava dizendo era que, do ponto de vista estrito da arquitetura, o movimento moderno, quando apareceu, eliminou a possibilidade de se considerar uma obra arquitetônica como uma obra de arte, como uma obra de arte autônoma tomada em si mesma. Ele apareceu justamente para contrariar a inclusão da arquitetura no sistema das belas artes. Com isto, a bela obra arquitetônica não era mais uma obra de arte, quando muito um sintoma (no sentido freudiano), como os estilos históricos do revivalismo burguês do século XIX. No que diz respeito às obras arquitetônicas anteriores, até mesmo o templo grego, a ideia de que se trata de uma obra de arte é uma ilusão retrospectiva, algo como o anacrônico juízo de gosto na origem dos museus imaginários da vida, que reúne num mesmo âmbito estético tudo aquilo que tinha funções sociais numa outra sociedade, do religioso ao político. O pendor vanguardista do movimento moderno foi mostrar que arquitetura não era escultura ou coisa que o valha, por mais que um construtivista prolongasse o gesto de Mondrian, mas tinha que ser transgressivamente funcional e é por isso que havia a esperança de que essa reordenação do espaço pudesse alterar a ordem social. E se se tratava de uma obra de arte, era justamente na intenção vanguardista de eliminar a distância estética entre arte e realidade. Como o projeto malogrou, a reunião museológica das sobras, por mais edificantes que sejam e nos falem ao coração, representaria um retrocesso nos termos mesmos dos modernos que projetavam pensando em acabar com tudo isso. Seria algo tão incongruente como um museu do Socialismo. Aguardemos o próximo capítulo. Se me expliquei bem, não se trata de um Fla-Flu 
amalucado do tipo ainda existe $\mathrm{x}$ não existe mais algo que se convencionou chamar experiência estética genuína. Até porque, seja dito de passagem, na sua dimensão antropológica elementar, de princípio estruturante do processo de individuação através do autodistanciamento pela imagem, pela faculdade ficcionalizante etc., a configuração estética da relação com o mundo é propriamente imperecível, salvo na situação inumana e terminal de uma absorção integral pela inconsciência de um ser mergulhado na positividade do imediato. Mas obviamente não é disso que se trata, assim como também não está em discussão a centralidade do trabalho na troca metabólica da sociedade com a natureza quando se discute a crise da sociedade do trabalho assalariado, abstrato e historicamente determinado. Como nos tempos de Hegel, ninguém está dizendo que a Arte acabou, mas simplesmente que a alta voltagem de uma primeira audição de Schönberg ou leitura de um trecho inacabado de Kafka não se repetirá mais com a intensidade e a verdade de quem se defronta com um limiar histórico.

É hoje corrente o diagnóstico de que a política tem um novo lugar. Segundo esse diagnóstico, a política tal qual a conhecíamos era um fenômeno essencialmente nacional e, atualmente, não seria mais evidente o pressuposto de um Estado Nacional como fonte e garante do Direito e como detentor do monopólio do exercício legítimo da violência. Como você vê tal diagnóstico? Na sua visão, a primazia de que parecem desfrutar as questões morais no debate público atual tem relação com esse novo estatuto da política em nossos dias?

Como professor de filosofia - e como estou sendo entrevistado nesta condição, preciso manter a ficção - não teria absolutamente nada a dizer, e nem poderia, pois os assuntos não se entroncam. E no entanto nossos coleguinhas andam opinando muito sobre isso. Mas o que seria um diagnóstico filosófico "profissional" sobre uma era pós-nacional? Diria que é ponto a meu favor essa brincadeira de mau gosto que consiste em dizer que, com a globalização, estamos nos aproximando da "paz perpétua" kantiana. Por aí vocês veem como a filosofia tornou-se, na sua sobrevida, uma máquina bisonha de disparates. Lembrem-se do Husserl que às vésperas do apocalipse nazista estava dizendo que era hora de ressuscitar o vigor da razão teórica - que só a teoria pura poderia recolocar a Europa em seu trilho rumo à ideia transcendental de humanidade. Bom, imaginar que a essa altura do campeonato, quando dois terços da humanidade vivem com menos de um dólar por dia, estamos nos aproximando da "paz perpétua” de Kant, já é um primeiro disparate. O segundo despropósito filosófico é o de imaginar que a ideia cosmopolita kantiana estaria prestes a se realizar. Que, com uma sociedade civil mundial, seremos todos cidadãos do mundo (Weltbürger). Mas agora o ponto é a favor da velha filosofia, pois Kant não era idiota. A ideia de Weltbürger de Kant não tem nada a ver com a ideia de Estado mundial. Aliás, para ele, a ideia de Estado mundial era o império, a pior das tiranias, o contrário da república. Imaginar-se, dessa forma, cosmopolita kantiano, fazendo parte de uma sociedade civil mundial é simplesmente se ajoelhar diante da tirania que virá na forma de um império, que aliás é um outro nome convencional para a espúria retomada da hegemonia americana, entenda-se: o poder econômico de emissão do dinheiro mundial lastreado pelo poder das armas. Weltbürger, para Kant, era simplesmente poder apelar para a opinião pública, para além do seu status 
particular. E essa opinião pública, para ele, era erudita e mundial, correspondia-se em latim. Portanto ser um cidadão do mundo é ser membro de uma república mundial das letras, em que todas as pessoas, independentemente da condição social, correspondem-se e argumentam entre si numa língua universal - o latim. Os filósofos de hoje estão contribuindo para o debate contemporâneo com essas enormidades.

É obvio que a febre ética de hoje é um pobre sucedâneo do empenho político bloqueado. Implicando um pouco mais com os nossos coleguinhas, não sei como os filósofos ainda não promoveram um revival do estoicismo romano, algo como uma etiqueta metafísica para se aguardar em casa o fim do mundo. Todo o refluxo de 1968 converteu-se nessa grande maré ética. Está aí o último Foucault que não me deixa mentir, para não falar na ética discursiva dos piedosos professores alemães. E tome ética disso e daquilo. (O outro encosto é a estética: basta um concerto da Filarmônica de Berlim, para a turma do esteticamente correto sentir a presença do absoluto e atravessar a cracolândia pisando em nuvens.) E mais "sociedade civil" a torto e a direito. Quem diria, antes teatro de uma guerra de posições, a sociedade civil hoje passa por espaço da liberdade, onde se "vive na verdade", como se dizia no leste Europeu. Ativistas sociais, socialites, próceres do big business suspiram em uníssono por mais autenticidade, como nos bons tempos do jargão existencialista. Só que o existencialismo agora é de mercado. A ética é um fator de produção, as empresas consideram o lucro um acidente operacional, sua vocação é toda cultura e cidadania. E por aí vamos. O curioso é que neste mundo esvaziado da guerra social de antigamente, é um deus nos acuda toda vez que cidadãos não-proprietários e politicamente ar- ticulados se aproximam demais do poder de Estado e do Banco Central, que continuam onde sempre estiveram. Está claro também que essa grande quermesse humanitária - que às vezes explode em surtos de histeria coletiva, pois há uma clara tendência à depressão gerada pela impotência flagrante das iniciativas éticas individuais para a calamidade coletiva em que se converteu o capitalismo hoje - se deve muito à percepção (não inteiramente equivocada) de que numa sociedade conectada horizontalmente em rede a questão social se resume à divisão entre os que estão "dentro" e os que estão "fora”, e sua resolução é um problema de "inserção" ou qualquer outra compensação, simbólica de preferência. Me parece uma questão de tempo identificar as novas formas de exploração e antagonismo sob a superfície ética da "exclusão". Quando se começa a falar demais em ética e seus derivados e patrocinadores, está-se dizendo outra coisa, na verdade um decreto sem apelação: a economia de mercado veio para ficar e estamos conversados.

Também me parece claro que tamanho frenesi ético de nossas elites e sua clientela (e nelas incluo contraelites à esquerda), para não falar em desfaçatez, algo tem a ver com o desmanche nacional em curso, que aliás não é fatalidade econômica natural mas fruto de decisões de comando político e dominação social num espaço mundial que nunca esteve tão hierarquizado e polarizado. Contraprova? Contento-me com um termo de comparação histórico. Considerando nossa problemática passagem de Colônia à Nação, Caio Prado Jr. costumava dizer que nos faltava o essencial, o "nexo moral”, que entendia como vínculo social, como um conjunto aglutinante de forças para além do laço meramente econômico do contrato mercantil. Pois era essa miséria "moral", própria de uma colônia de 
exploração, mero empreendimento comercial - éramos um vasto empório regido pelo mais cruento cálculo econômico, o do lucro auferido com o trabalho escravo e o "trato dos viventes" - que nos inviabilizava como sociedade. Como ultrapassar o mercado rumo à nação? Esse o drama. Inclusive do pensamento progressista ulterior, que aliás complicou-se ainda mais ao inverter o raciocínio — até hoje: a ideia "moral" de sociedade foi rifada porque algo como uma economia nacional foi para o ralo. Ou seja, não há nação sem mercado interno e toca a procurar pelo em ovo, em arrancar um nexo societário não-mercantil da forma-mercadoria! Mercado não forma nação. A prova está aí: hoje, com muito otimismo, somos apenas um mercado, ora emergente, ora submergente. Como se eclipsou o "nexo moral" demandado por Caio Prado, junto com a atual reconversão colonial-mercantil veio o autoengano ético que estamos vendo.

Como você caracterizaria a sua relação com a religião e a fé?

Foi uma relação pretérita, de adolescente. Atualmente, para mim, é apenas um fenômeno sociológico. Não tem o menor significado pessoal.

Como você se situa em relação aos problemas de uma "mudança de paradigma" da filosofia, de uma filosofia "pós-metafísica" calcada na linguagem?

Se eu ainda desse aula, começaria pelo seguinte esclarecimento: essa conversa de mudança ou crise de paradigma a três por dois começou com o senhor Thomas Kuhn, para dar conta do que estava acontecendo com a mudan- ça de humores da epistemologia americana. Em meados dos anos 60, antes do desembarque da ideologia francesa, chegou aos ouvidos americanos a notícia de que as verdades científicas são históricas, independentemente da sua verificação empírica, e dependiam de um consenso entre aqueles que estavam envolvidos no debate. E redescobriram coisas que os alemães estavam falando desde o historicismo do século XIX. Entre outras coisas que a ciência fazia parte de um sistema chamado cultura, banalidade da qual os antropólogos há um bom tempo sabiam extrair consequências interessantes. A ideia de paradigma começou com isso, com a ideia de historicização do núcleo duro e positivo do pensamento científico.

O interessante é que houve antes, na virada de século filosófico, um "giro linguístico" endógeno, uma tradição interna que se iniciou com Frege - que não por acaso vinha da matemática - , desviando-se da filosofia da consciência - predominante na Alemanha até a fenomenologia —, e migrou para a Inglaterra, na recepção de um Bertrand Russell. Depois vieram os austríacos, Wittgenstein e assim por diante. Isso foi uma questão interna, a transformação da filosofia profissional, até então centrada na ideia de representação, que passou com armas e bagagens da consciência para a linguagem. Mas continuou sendo filosofia profissional e, portanto, não mudou nada em relação à linhagem moderna, que vinha de Kant. O famoso "giro linguístico" não mudou nada. Simplesmente a filosofia universitária livrou-se da ganga psicologizante e passou para a análise lógica do conhecimento.

A virada que nos importa, a conversão ao paradigma comunicacional, onde sobressai a dimensão pragmática da linguagem, é da metade deste século. De qualquer maneira, esse giro começou a aparecer quando o élan 
"desenvolvimentista" geral (algo como uma convergência modernizante dos vários caminhos nacionais), no centro, com o Welfare State, e na periferia, com a industrialização, começou a implodir e a desacreditar a noção "progressista" de progresso. Depois isso foi banalizado pelos pós-modernos como o "declínio das grandes narrativas", na verdade apenas uma estilização de fatos reais, nada que se assemelhasse a uma ruptura na História do Ser. Nesse momento, ficou mais ou menos claro que a noção de progresso supunha continuidade, e que progresso com continuidade supunha uma matriz que lhe é coextensiva, chamada tempo e consciência. Então as filosofias da consciência e da temporalidade começaram a cair em desgraça, como também as decisões que envolviam tempo e consciência, como a ideia de sentido e engajamento da filosofia existencialista. Como essa parafernália começasse a periclitar, a panaceia da linguagem passou para o primeiro plano. De início através do estruturalismo linguístico, que foi apropriado primeiramente pelos antropólogos e, só depois, pelos filósofos. Quando os filósofos “arrombaram" essa porta aberta e descobriram a América, para a antropologia já era uma evidência o fato de as sociedades viverem mergulhadas em sistemas simbólicos, evidência, que ao se generalizar, se exprime hoje na convicção de que até a economia se tornou cultural. Portanto, tanto a ideia de progresso, quanto a ideia neopositivista de objetividade como teste último de realidade, foram para o brejo, pois só há significações socialmente construídas. (Grandes novidades... E como rola tinta.)

Só que, nesse momento, as ideias herdadas de objetividade, de progresso, de consciência e de temporalidade estavam desmoronando, porque a sociedade do capitalismo organizado também estava. O crescimento com pleno emprego fora deslegitimado, o motor material da antiga consciência; o sujeito forte da sociedade liberal burguesa, também tinha se eclipsado. Vieram os pós-estruturalistas franceses e obviamente fizeram a festa. Derrida tem pelo menos faro, porque a Desconstrução nada mais é do que a súmula dos fatos muito pouco metafísicos estilizados pelo colapso dessa geocultura progressista de legitimação do capitalismo, como Roberto foi o primeiro a lembrar certa vez, em 1994, num breve ensaio de primeira intitulado "Fim de século". Na outra ponta, um sociólogo francês, Luc Boltanski, também foi o primeito a notar que, pensando bem, os rizomas de Deleuze são uma abreviatura "ideológica” da Sociedade em Rede. Convenhamos: esses ideólogos franceses no fundo eram excelentes sismógrafos, porém inidôneos como toda apologia indireta, como diria o velho Lukács, com perdão da má lembrança. Mas a estilização destes fatos também produziu incongruências. Por exemplo o nosso amigo Habermas, um dos teóricos dessa mudança de paradigma. Ele achou que o finado paradigma da consciência tinha um prolongamento, a sociedade do trabalho, e seu correspondente paradigma, o da produção. Portanto, para continuar modernizando a modernidade, Habermas afirmou que seria necessário repensá-la por meio do paradigma da comunicação, coisa de que os pós-modernos vinham falando fazia tempo. Ele formulou isso no início dos anos 80, e os estruturalistas franceses estavam dizendo isso há vinte anos. Assim, o pobre Habermas escreveu todo o Discurso filosófico da modernidade, com capítulos sobre Derrida, Foucault etc. para dizer a mesma coisa. Qual era a briga de Foucault com a esquerda francesa marxista? Era "tchau trabalho". E a de Derrida também. Entre outras razões, era por isso que eles estavam flertando com o "gauchismo" cultural e 
antiprodutivista de 1968. É claro que eu estou brincando, porque obviamente há um abismo entre Foucault e Habermas. Mas estão todos no mesmo barco. Então a polêmica com o pós-estruturalismo francês, no Discurso, não exprime esse confronto inapelável que o debate a respeito procura dar a entender. Prova disso: todos se encontraram, estão abraçados - com suas diferenças de praxe -, nos EUA. Onde encontramos pragmatismo local (revitalizado pelo pós-estruturalismo francês), onde está a esquerda cultural americana, e a versão americana da última teoria crítica - Habermas. Estão todos abraçados no mesmo paradigma. Seria interessante deixar um pouco de lado essa conversa toda sobre mudança de paradigma e procurar entender o esgotamento histórico real de que ela de fato é apenas a sintomática desconversa.

Você utilizaria o conceito de "utopia" para descrever a sua visão do futuro da sociedade humana? Em que consistiria tal utopia?

Ainda sou de opinião que utopia é uma palavra para abreviar socialismo. A pergunta, assim, é: "o que se pode considerar socialismo hoje?" - e já é difícil manter até a palavra "socialismo" na medida em que o socialismo real a enxovalhou. Então é necessário imaginar uma sociedade pós-capitalista que não seja apenas utópica no sentido de uma ideia moral reguladora. Isso eu deixo para as ONGs fazerem [risos]. Por outro lado - e a encrenca é essa —, é necessário imaginar uma sociedade pós-capitalista, e ver se e como as coisas vão de fato nessa direção. O que Marx queria dizer com utopia? Exatamente o contrário do que estou procurando indicar agora. Utopista, para Marx, era o pessoal que procurava se organizar à margem da so- ciedade de mercado em constituição, isto é, era a reação defensiva do campesinato se proletarizando. Essa gente brutalmente despossuída imaginava poder reconstituir uma espécie de economia natural à margem da nova sociedade do capital, organizando-se por exemplo na forma de cooperativas. O que Marx dizia? "Vão morrer na beira da estrada. Eles têm de mergulhar na grande corrente histórica que por meio de uma reviravolta épica vai dar no socialismo. Vão sofrer, mas, no fim, vai dar tudo certo”. Esse era o socialismo "científico", movimento social por assim dizer garantido por uma mola propulsora nada "científica" chamada negação da negação. Mas imaginem dizer isso em 1848: era o horror dos horrores. A nova sociedade era uma coisa sinistra, a miséria um coisa inacreditável, e, no fundo, Marx estava dizendo: "seus bisnetos, daqui a cem anos, estarão no Welfare State europeu. Padeçam o inferno, mas não tentem se organizar fora desse troço”. Ele tinha razão, a proletarização engoliu todo o mundo.

Ora, o drama atual, nesse jogo de utopia e socialismo, é que essa ladainha sentimental da exclusão é falsa. Nunca todo o mundo esteve tão incluído como hoje em dia. É certo que estamos ferrados, e isso é outra coisa - pois viramos lixo descartável destinado ao aterro sanitário social. Os descartados não estão excluídos. São descartados porque estão absolutamente incluídos. Esse é o drama dessa nova etapa.

Então a ideia de utopia, de uma saída possível, está se tornando socialmente proibitiva. E o socialismo também. A ideia clássica de socialismo tem de ser inteiramente repensada. O que significava socialismo? A verossimilhança política e sentimental do socialismo significava que quem era socialista representava alguma coisa de novo. $\mathrm{O}$ socialismo era uma tendência real e visível. E era possível 
apontar esta tendência como algo que já suplantava o que estava aí, e que era melhor. E isto passava tanto pela vida pessoal quanto pela organização produtiva. Mesmo sendo moderna e capitalista, a sociedade liberal-burguesa se apresentava assim mesmo como uma ordem tradicional, a cuja constante inovação produtiva correspondia uma espécie de bolor cultural, de mofo moral, sem falar é claro na opressão econômica de sempre. De qualquer modo era um mundo no qual se sufocava e os socialistas vinham trazer o ar fresco da história, que tinham a seu favor.

Hoje o negócio mudou, e quem fala em socialismo parece ter ficado para trás. Não se pode apontar um obstáculo material ou moral que o mercado não se encarregue de superar. A ideia de que havia uma sociedade pós-burguesa ao alcance da mão, uma espécie de promessa embutida na antiga ordem, que se caminhava em direção a ela, saiu de cena. A prova mais extraordinária dessa recuperação permanente é o movimento de emancipação das mulheres, talvez a maior revolução desde o neolítico. E o que mudou? Nada. Ao mesmo tempo em que houve uma revolução, a sociedade de mercado incorporou essa revolução. Isso significa que a ideia de limite a ser transposto em direção ao socialismo desapareceu repentinamente do horizonte. Se analisarmos o ciclo das grandes revoluções antissistêmicas deste século, de 1917 a 1949 (Revolução Chinesa), não seria disparatado afirmar que o capitalismo encalacrado estava por um fio, e que o mundo do trabalho tinha inclusive o progresso técnico em seu poder, portanto em condições de desbloquear aquele fim de linha civilizacional. Era verossímil a possibilidade real de se encerrar a pré-história da humanidade. Hoje, não. Ou novamente, ainda não.

A esse propósito, gostaria de falar um pouco do livro de Paul Singer, Utopia militante, publicado pela coleção
Zero à Esquerda. O que está fora de cogitação, no seu breviário? Paul Singer mostra que não podemos mais pensar segundo a lógica binária campo contra campo, isto é, o socialismo não mais virá pela expropriação de uma classe por outra que, organizada em Estado, socializará os meios de produção. Isto está fora de cogitação, vide o exemplo da União Soviética. O socialismo, diz ele, tem de ocorrer por meio de algo como uma adesão voluntária, através de "implantes" socialistas, o que ele chama de ilhas de economia solidária dentro de uma economia de mercado capitalista dominante. Então vão se criando essas pequenas ilhas de sociabilidade não inteiramente organizadas pelo nexo mercantil. Essas ilhas, no entanto, precisam ter algum tipo de relação com o "exterior”, precisam vender os seus produtos no mercado. Paul Singer começa a fazer revisões extraordinárias. O que são esses implantes socialistas para ele? O sufrágio universal é um implante socialista. Como assim? Ora, socialismo e democracia, para Singer, são sinônimos. O sufrágio universal foi "arrancado" pelos de baixo. O Estado de Direito também é um implante socialista, também foi arrancado pelos despossuídos, pois o Estado liberal sempre foi oligárquico. O direito de associação sindical também é um implante socialista. O Welfare State também, e assim por diante. Como Paul Singer não é dado a especulações teóricas, o que acho que ele está dizendo é: a realização do socialismo não está mais garantida por uma dialética imanente. Não há mais uma reviravolta produzida pelo próprio sistema, mas esses implantes que tendem a se alastrar por adesão voluntária e deverão demonstrar a sua superioridade material e moral sobre o conjunto da sociedade.

Seria possível, no entanto, relembrar a Paul Singer que isto também aconteceu na passagem do Antigo Re- 
gime para o capitalismo, pois também nessa época se poderia falar em implantes capitalistas. Esses implantes passaram a desorganizar e a reorganizar os mercados locais - a interconectá-los - passaram a financiar a produção, e só venceram a parada porque esse novo arranjo da vida econômica revelou-se produtivo. Marx viu isso muito bem: a passagem foi irresistível porque desenvolveu de maneira exponencial as forças produtivas da sociedade. Então é preciso perguntar a Paul Singer: "O que você faz com esse problema? Você está raciocinando por analogia, e, conforme esse raciocínio, tais implantes deveriam arrebatar toda a sociedade por adesão voluntária? Onde a superioridade das novas forças produtivas?". Ele diria: “É verdade, mas nós temos de pensar que, do ponto de vista do desenvolvimento das forças produtivas e da organização capitalista conforme a esse desenvolvimento, o capitalismo é um desastre no que diz respeito, por exemplo, a coisas fundamentais para a vida civilizada como a saúde, a educação, a ecologia etc. É por aí que se deve começar". Ora, a saúde é uma calamidade - a grande maioria das populações vai morrer porque não pode pagar os custos capitalistas da medicina - e alguma coisa tem de ser feita. O mesmo raciocínio serve para a educação. Dessa maneira, é possível imaginar que nesses domínios pode-se quebrar com a ideia de um horizonte intransponível. Essa "utopia militante" para Paul Singer é a imaginação dessa ordem pós-capitalista que pode ser antevista ao vivo com tais ilhas. E essas ilhas utópicas podem ser entendidas no seu sentido antigo. É por isso que, atualmente, Paul Singer tornou-se também erudito em história do socialismo cooperativo dito utópico. Trata-se de uma aposta, pode dar tudo errado, mas é um caminho, entre outros ainda por descobrir, dentro e fora do mundo do trabalho, que abso- lutamente não acabou, nunca se trabalhou tanto e tão mal em empresas podres em troca de dinheiro.

A outra discussão a respeito do livro de Paul Singer é sobre a questão do Estado, e portanto do crédito. As cooperativas precisam de crédito. Já se disse ao Paul Singer: "É necessário pensar macro, porque quem controla o crédito em uma economia capitalista controla tudo", como vem dizendo e argumentando Fernando Haddad, no qual me inspiro e espero ter entendido bem. Não é à toa que bancos e Estado estão sempre juntos. E o controle do crédito é político. Num certo sentido, não seria um despropósito dizer que os bancos deveriam estar fora do mercado, pois dinheiro não é mercadoria, como trabalho e terra também não são. Então o problema do crédito nesses implantes utópicos pós-capitalistas repõe todo o problema clássico de uma sociedade de classes antagônicas em que a economia é de comando político. Até a era liberal foi um ciclo histórico de capitalismo politizado até a medula. Com o crédito, o Estado entra na equação, ou seja, a disputa entre as classes pelo crédito passa pelo confronto com o Estado. O dinheiro é um artefato político e o curso da moeda é uma peça fundamental da dominação social. Câmbio e juros são instrumentos políticos, não decisões de mercado - só aquele paranoico do Gustavo Franco achava que banana e câmbio eram a mesma coisa. Nada mais político do que a briga pelo controle do câmbio e do dinheiro. Ora, com isto, é possível voltar ao conflito macro, de modo que volta a luta política, volta a luta pelo controle do Estado. Se se chegar ao problema do dinheiro e do crédito, chega-se ao coração do sistema, e obviamente os atuais donos do mundo não vão deixar barato, só mortos largarão o osso.

Portanto, o Estado será sempre essencial. Ele só está sendo desmanchado e deslegitimado para os de baixo. 
Para os de cima, ele nunca foi tão organizado, tão eficiente, tão dinâmico e tão associado às finanças, que, por sua vez, estão associadas à tecnologia de ponta. Se se for ao crédito e a esse Estado que está funcionando bem aqui no Brasil, vai-se ao coração do sistema, sem o ônus das categorias tradicionais do socialismo. E passa a ser necessário saber quem se beneficia disso, quais são as classes sociais, para saber com quem se aliar e o que se vai dizer e fazer em função dessa relação entre poder e dinheiro. Por isso que é preciso uma nova teoria das classes. Dissociar Estado e mercado e dizer que estamos indo em direção a uma sociedade civil global é reles enganação.

Nossa sociedade produz incessantemente elementos autodestrutivos como riscos ambientais globais, ameaças de desintegração social em larga escala e alienação cultural em massa. Como você vê tais problemas?

"Nossa sociedade" de quem? Por que não dizer de uma vez que o capitalismo, e não a "nossa sociedade", que nunca foi nossa, tornou-se mais uma vez uma ameaça à sobrevivência da espécie no planeta (os energúmenos e outros deslumbrados falam em Renascimento), e que toda vez que "nossa sociedade" se vê ameaçada a esse ponto insano de insegurança, responde com o fascismo? Tomada ao pé da letra, a gracinha sociológica chamada Sociedade Global de Risco é isso 


\section{EPÍLOGO}

\section{BEIJANDO A CRUZ}

\section{Beijando a cruz*}

Começo pelo Antigo Testamento. Na fórmula famosa e ainda verdadeira, o Capital é a própria contradição em processo. Valor que se autovaloriza sugando o mesmo trabalho vivo que se empenha em tornar cada vez mais redundante. Em busca de sobrevida, foge para a frente. A desmedida e a escalada se encontram no seu DNA. Não surpreende portanto a regularidade com que tende à autodestruição. Em plano ciclópico, nas guerras pela hegemonia mundial. Em tais ocasiões, arrasta consigo todas as classes sociais, anestesiadas em seu antagonismo pelo contágio de tamanha compulsão para o desastre. A primeira grande revelação deu-se em agosto de 1914, quando as classes trabalhadoras, alinhadas com suas respectivas burguesias imperialistas, marcharam para o matadouro. A derradeira está começando a se desenrolar diante dos nossos olhos. É bom esfregá-los bem. Recentemente, embandeirados operários americanos da construção civil se reuniram em Nova York para manifestar apoio a uma guerra de ocupação que lhes renderá empregos no ramos promissor da reconstrução humanitária. Seja qual for a agenda oculta da presente guerra, uma coisa é certa: trata-se de uma guerra sem futuro, se é que se pode falar assim. A prova por absurdo deste fim de linha transparece já na obscena cegueira de manchetes do tipo: "rápido fim da guerra no Iraque aumenta otimismo dos investidores

* Publicado originalmente em Reportagem, São Paulo, abril de 2003. 
globais com os mercados emergentes". Logo saberemos.

Caso o século que se inicia testemunhe o recomeço do Grande Jogo para o controle da Eurásia - quer dizer, a disputa de morte pelo novo dinheiro mundial e recursos energéticos cada vez mais escassos -, não é inverossímil antever no seu desfecho algo como um End Game beckettiano para as sociedades industriais, no prognóstico bem argumentado de Richard Heinberg. Digamos que o desenlace tende mais para uma ditadura militar global do que par um novo Bretton Woods. Na verdade, sempre estivemos às voltas com um sistema suicida. Só mesmo por efeito de uma miragem retrospectiva deixamos nostalgicamente de enxergar na prosperidade dos trinta anos de consenso keynesiano a vida à beira do abismo termonuclear, como se uma não fosse possível sem a outra, uma economia de preparação permanente para a guerra e a felicidade material das classes confortáveis. Pois bem: estamos inaugurando uma nova Era, algo como um Estado de Emergência planetário, em que o triunfo ideológico avassalador do capitalismo e o seu novo ímpeto suicida correm um na direção do outro. O espantoso paradoxo de nosso tempo vem a ser a reativação desta esquizofrenia estrutural. Não há um agente do mercado que ignore o caráter destrutivo da livre circulação dos capitais num universo essencialmente assimétrico, e no entanto, não desgrudam os olhos dos monitores. Na boa pergunta de Robert Kurz, por que tanta indignação com o fundamentalismo dos homens-bomba ao lado de igual confiança cega no programa demente da economia global de mercado?

Aqui entramos nós. O risco país diminui, o dólar recua, a inflação desacelera e até já viramos "a estrela dos emergentes no pós-guerra" e contudo é bem provável que um historiador do futuro intitule o capítulo referente ao período inaugurado pelo triunfo eleitoral do maior partido de esquerda do ocidente, Crônica de um Suicídio.

No primeiro mês de governo não por acaso falou-se muito em esquizofrenia a propósito do desencontro sabido: discurso enfático à esquerda, e muita energia no encaminhamento de políticas or todoxas. Quatro meses depois, a mudança de rota assumiu proporções tais que já não é mais possível recusar a hipótese da autodestruição, nos termos enunciados acima - menos um trivial tiro no pé (esquerdo) em matéria de política econômica, do que uma fulminante conversão à lógica mortal da crise. Não vou, nem poderia, discutir alternativas macroeconômicas, nem chorar o leite derramado, toda a tradição crítica brasileira e latino-americana descartada sem maiores considerandos. Creio todavia que também interessa e muito identificar a natureza da mutação quase antropológica em curso, a continuidade por assim dizer "espiritual” lograda por um sistema de dominação social tão acachapante que pode se dar ao luxo de se perpetuar entregando o comando primeiro a um sociólogo acometido de apoteoso mental, depois a um líder sindical generosamente empenhado em levar todas as classes sócias à mesa da comunhão nacional. Tampouco explica muita coisa observar que o próprio Partido dos Trabalhadores já vinha entregando os pontos há um bom tempo. Pelo contrário, apesar de todos os pesares, durante a campanha o show de vileza e terror econômico em que se esmerou a direita prestou o inestimável favor de revelar o irreconciliável inimigo de classe num adversário eleitoral que apenas vendia paz-e-amor e outras amenidades. A memória recente deste antagonismo só fez aumentar a estupefação provocada pela retomada da agenda falida do período anterior e seu cortejo de racionalizações mambembes. 
Não é falso afirmar que a lógica da situação finalmente se impôs e que beijando a cruz - primeiro na Carta aos Brasileiros, em seguida endossando o acordo com o FMI, Lula teria selado o seu destino. Também não é falso alegar a herança de um país arruinado para além da imaginação. Como deve ter pesado igualmente a percepção de que a eleição foi ganha um pouco por acaso e no centro do espectro político, onde reinam os temores de uma classe média tão conservadora quanto sua congênere Argentina, que aliás se prepara para cometer um segundo suicídio, tomada pela mesma certeza paralisante de que qualquer mudança será sempre para pior. A essa visão se somaria outra não menos verdadeira de que tal imaginário congelado contagiara amplos setores das camadas populares.

O que pensar? Aqui uma chave possível para todo esse maldito imbróglio - infelizmente um tanto remota ou "filosófica", mas não vejo outra para tamanha reviravolta. A boa pergunta neste caso talvez seja a mais rasa de todas: afinal, o que fez a cabeça do núcleo duro do governo? Não se trata de simples adesão a tal ou qual doutrina, isso é mera consequência. Trata-se a rigor de um ritual. Isso mesmo, algo como uma prática material muito próxima da gesticulação religiosa. E de fato tudo se passa como se nos defrontássemos com uma verdadeira conversão à "religião da vida cotidiana", como Marx se referia à liturgia requerida pelo serviço do Capital. Parece até behaviorismo, pois "reforço" é o que não falta.

Me explico. Segundo o filósofo Slavoj Zizek, deveríamos reler numa outra chave a célebre frase de Marx a respeito do modo de funcionamento da ideologia enquanto falsa consciência: "disso eles não sabem, mas o fazem". A seu ver, a ilusão ideológica não se situa no "saber" mas no "fazer". Reconsideremos por este ângulo o nosso dra- ma. A primeira vista, o desconcerto atual decorreria da discrepância entre o que a esquerda no governo efetivamente faz e o que pensa estar fazendo. Seria então o caso de ajustar discurso e realidade, ultrapassando esta divisão interna etc. Acontece que não é bem assim, é muito mais grave. Lula e seus companheiros sabem muito bem como as coisas são, mas continuam a agir como se não soubessem. Durante oito anos demonstramos a falência de uma receita para o desastre, mas agora vai dar certo... O osso é bem mais duro de roer porque, ao contrário do grupo dominante anterior, não são cínicos, não gozam da impunidade de classe que permitia ornamentar o esbulho com asneiras sociológicas. A boa fé de agora porém é de outra ordem. No esquema proposto, nos deparamos com uma crença muito especial, pois não se trata em absoluto de um estado mental interno, mas de "uma crença radicalmente externa, incorporada no procedimento efetivo das pessoas". O exemplo de Kafka talvez ajude. Sabemos que a burocracia não é assim tão onipotente como é representada no universo kafkiano, mas é esse "exagero" o verdadeiro assunto. Ele não se encontra no que sabemos a respeito, mas no âmago de nossa conduta efetiva na presença da máquina burocrática, conduta justamente regulada por uma crença em sua onipotência. Ou por outra, agimos como se acreditássemos na sua onipotência. Sobre este "como se" ergue-se toda a construção da realidade. Tal como o rei do exemplo de Marx: "um homem só é rei porque outros homens colocam-se numa relação de súditos com ele. E eles, ao contrário, imaginam ser súditos por ele ser rei”. Mas essa "imaginação" está por assim dizer lá fora, sustentando o vínculo social.

A bizarra teologia materialista do Pascal, redescoberta por Zizek, nos permitirá entrever ainda melhor o enig- 
ma da conversão que está derrubando e desmoralizando a esquerda brasileira. Como somos "tanto autômato quanto mente", provas, segundo Pascal, convencem apenas a mente, enquanto o hábito fornece as provas em que verdadeiramente acreditamos, daí a sua força, que dobra o autômato que somos. Pois esse autômato "inconscientemente leva a mente consigo". Creio que foi este automatismo que operou o milagre e fez enfim o PT ver a luz. Numa palavra (do filósofo), se os sujeitos não acreditam, as coisas acreditam por eles. Essa a base mística da autoridade do Capital. Sabemos que é apenas uma relação social, de exploração ainda por cima, e que não há nada de mágico nisso, mas agimos como se não soubéssemos.

Beijar a cruz deve ser tomado nessa acepção pascaliana e materialista. Voltemos à lógica da situação, ao ABC da política contemporânea, vender confiança aos mercados e reduzir os custos da incerteza, que podem ser fatais num sistema desenhado para operar sob a ameaça permanente da morte súbita. Mas como vender credibilidade sem crer? Vinte anos de ateísmo não recomendam. Tampouco declarações registradas em cartório. Da esquerda exige-se uma profissão de fé que em princípio ela não poderia oferecer. Só um milagre. Que afinal aconteceu. Nos termos de há pouco, encarregaram as coisas, que povoam o mundo religioso da vida cotidiana regulada pelos mercados, de acreditarem por nós. "Você quer descobrir a fé e não sabe o caminho? Quer curar-se da descrença e roga por remédio?" acudia Pascal à aflição de uma consciência de cuja constituição originária inibia a aposta em Deus "minhas mãos estão atados e meus lábios cerrados; sou forçado a apostar e não estou livre”. Pois então, prosseguia, "aprenda com aqueles que um dia estiveram atados com o você e que agora apostam tudo o que têm”. Religião- -cassino, numa palavra, sem falar no comportamento de drogado do apostador. Conhecemos a receita, a do hábito que dobra o autômato em nós. Como diria outro filósofo (mais um), confiem no crescimento da composição orgânica do ser humano, cada vez mais análoga à do próprio Capital. William Randolph Hearst, o Cidadão Kane, acrescentaria que nunca se perde dinheiro quando se subestima a "mente" em favor do "autômato". Voltando ao caminho das pedras: "eles se portaram exatamente como se acreditassem, recebendo água-benta, mandando rezar missas e assim por diante. Isso o fará acreditar com muita naturalidade". Em suma, beijar a cruz uma ou duas vezes por semana. Quer dizer: "submeta-se ao ritual ideológico, entorpeça-se repetindo os gestos sem sentido, aja como se já acreditasse, e a crença virá por si só”, esta a súmula do sistema lotérico de Pascal.

Armou-se em consequência no governo algo como um serviço Delivery [ver ao lado artigo de Leda Maria Paulani e Fernando Haddad]. De tanto entregar o prometido, com a exata regularidade litúrgica recomendada por nosso consultor ad hoc, a lógica da aposta na Agenda virou fé, que por sua vez irradia na forma da credibilidade almejada. Aposta por necessidade de sobrevivência, não há dúvida. Aliás o cerne mesmo da estratégia de venda da vida eterna concebida por uma gênio do marketing como Pascal. Há mais ainda, o inestimável conforto de não precisar renunciar às convicções anteriores. Se a fé que gera credibilidade se materializa num ritual externo, minha crença íntima pode continuar publicamente animada por reminiscências de esquerda: o Capital não se queixa, até agradece, pois “objetivamente" estarei rezando. Daí a sensação de esquizofrenia. Ou de suicídio, apenas o observador se afaste um passo que seja. O diabo (não há outra 
palavra) é que o automatismo de um tal sistema de dominação, justamente por ser impessoal e cego, sempre joga a favor dos exploradores, mesmo quando os ameaça de destruição. Em cima há sempre mais escolhas do que risco, reservado com exclusividade aos de baixo.

Fantasia teórica? O raciocínio pode parecer extravagante, porém no fundo nada mais fiz do que estender democraticamente ao aparelho dirigente, e hoje governante, de um grande partido de esquerda, o mesmíssimo argumento que o melhor de nossa reflexão crítica vem desenvolvendo acerca dos derradeiros e assustadores desdobramentos da sociedade de consumo. Como neste aspecto os sistema não cuida muito de distinguir elite e massa, é só inverter o raciocínio e verificar que, na sua ânsia desmedida de gratificação, o consumidor anônimo de todos os dias também se ajoelha diante das grandes marcas e beija a cruz. E também sabe perfeitamente que a grife é apenas um nome, e no entanto, procede como se não soubesse. Novamente dissociação entre sentimento pessoal e agenciamento externo da crença através do rito sumário do consumo. No final das contas, as conversões espetaculares de partidos de esquerda pesam bem menos no triunfo atual da contrarrevolução capitalista do que o consentimento de massa gerado por tais práticas materiais. O keynesianismo americano de guerra mal poderia sufocar o sistema soviético não fosse a corrosão interna do consumo reprimido pela ditadura da escassez. Aqui o viés autodestrutivo da atual "normalidade" capitalista, a junção entre o reflexo pavloviano dos agentes do mercado e seus operadores políticos e a violenta ilimitação dessa demanda imperativa do consumo de massa. Uma confluência a tal ponto mortífera que não seria injusto incluir esse gigantesco exército de crentes numa espécie de extensão da atual máquina de guerra imperial, que afinal existe para perpetuar essa insaciável fome canina do consumo e seu custo energético demente. Não penso ser injusto encaixar nessa gravitação de conjunto a conversão suicida do Governo Lula à ortodoxia econômica. Um alto dignitário do novo regime afirmou recentemente que uma tal linha justa veio para ficar, pois a crise internacional seria permanente. Essa a lógica do estado perpétuo de emergência.

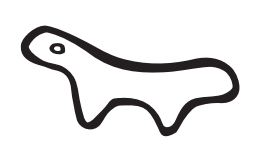

Este livro foi composto nas fontes Literata e Work Sans em novembro de 2021. 